University of Rhode Island

DigitalCommons@URI

Open Access Master's Theses

1990

\title{
The Planner's Database: Foster, Rhode Island
}

Steven P. Fusco

University of Rhode Island

Michael A. Phillips

University of Rhode Island

Terence M. Whalen

University of Rhode Island

Follow this and additional works at: https://digitalcommons.uri.edu/theses

\section{Recommended Citation}

Fusco, Steven P.; Phillips, Michael A.; and Whalen, Terence M., "The Planner's Database: Foster, Rhode Island" (1990). Open Access Master's Theses. Paper 657.

https://digitalcommons.uri.edu/theses/657

This Thesis is brought to you for free and open access by DigitalCommons@URI. It has been accepted for inclusion in Open Access Master's Theses by an authorized administrator of DigitalCommons@URI. For more information, please contact digitalcommons-group@uri.edu. 
THE PLANNER'S DATABASE:

FOSTER, RHODE ISLAND

BY

STEVEN P. FUSCO

MICHAEL A. PHILIIPS

TERENCE M. WHALEN

A RESEARCH PROJECT SUBMITTED IN

PARTIAL FULFILLMENT OF THE REQUIREMENTS

FOR THE DEGREE AND MASTER OF

COMMUNITY PLANNING

UNIVERSITY OF RHODE ISLAND

1990 
MASTER OF COMMUNITY PLANNING

RESEARCH PROJECT

OF

STEVEN P. FUSCO

MICHAEL A. PHILLIPS

TERENCE $M$. WHALEN
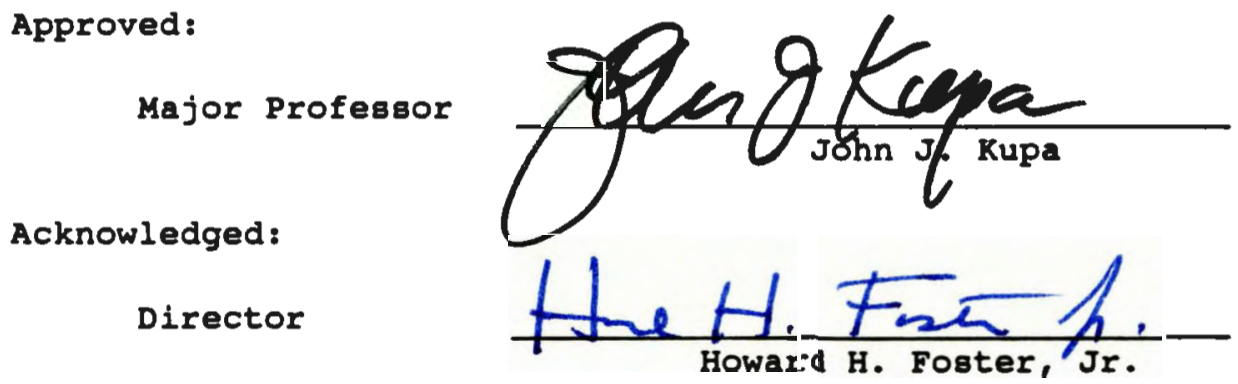
This project could not have been possible without the contributions of many people. In particular, the Project Team would like to thank the women in the Foster Town clerk's office; Heidi colwell, Anne Carlson, Tina simula and Maureen Comerford, for their extraordinary patience and good humor during many long days of data collection. In addition we would like to thank David winsor for his valuable advice and contributions. Finally, we would like to recognize our major professor, Dr. John Kupa for his unending enthusiasm and encouragement that kept us focused and on schedule. 
A C K N O W L E D E M E T S .................. 11

L I S T OF T A I E S . . . . . . . . . . . . . v v

L I S T OF F I G U R E S ................... . vi

C H A P T E R O N E

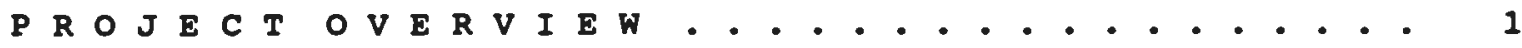

The Project Area . . . . . . . . . . . . . 1

The Project Concept . . . . . . . . . . . . . . . 4

Computer Database Capabilities ........... 7

C H A P T E R T W O

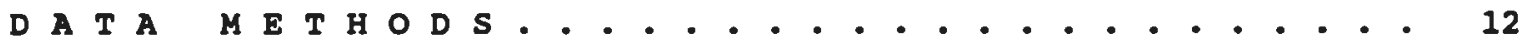

Data collection .............. . . 12

Data Fielda.................. 15

Map and Lot Description ........... . 15

Land Value . . . . . . . . . . . . . . 16

Building Value ............... 17

Lot Size . . . . . . . . . . . . . 18

zoning ................... . . 18

Land Use . . . . . . . . . . . . . . 19

Building Grade . . . . . . . . . . . . 19

Number of Stories . . . . . . . . . . . 21

occupancy . . . . . . . . . . . . . . . 21

Heating Fuel Type ................. 21

Number of Bathrooms . . . . . . . . . . . . 22

Number of Bedrooms . . . . . . . . . . . . 22

Total Number of Rooms . . . . . . . . . . . 22

Building Age .................. . 23

First Floor Square Footage ........... 23

Lot Frontage .................. 24

Watershed .................... 24

Wetlands ................... 24

C H A P T E R T H R E E

D A T A B S E A D M I N I S T R A T I N . . . . . . . . 26

Administration Overview . . . . . . . . . . . 26

Update Procedure .................. 27 
TABLE OF conPENTS (continued...)

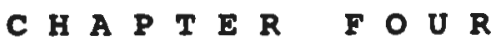

A P P I I C A T I O N S . . . . . . . . . . . . . . . . . 32

Present Conditions . . . . . . . . . . . . . . 33

Land Use Summary . . . . . . . . . . . . 33

Vacant Land Summary . . . . . . . . . . . . 36

Basic Housing Characteristics. . . . . . . . 39

Energy Use . . . . . . . . . . . . . . 42

Forecasting Uвes . . . . . . . . . . . . . . . . . 45

Population Estimate . . . . . . . . . . . . 45

Frontage Buildout . . . . . . . . . . . . 48

Backlot Buildout . . . . . . . . . . . . . . 51

Frontage Buildout Population Estimate . . . . . 54

Fiscal Implications of Buildout . . . . . . . . 55

Scenario Building . . . . . . . . . . . . . . . . 58

Analyzing the Effects of Proposed Legislation . - 58

Identification of Land for Acquisition . . . . . 61

Archiving Summary statistics . . . . . . . . 63

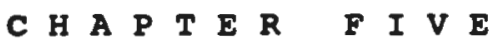

R E C O M M E N D A T I O N S........................ 76

Additional Data Fields . . . . . . . . . . . . . 76

soil type... . . . . . . . . . . . . 76

Steep slopes . . . . . . . . . . . . 77

Aquifer . . . . . . . . . . . . . . . 78

Endangered Species . . . . . . . . . . . . 78

General suggestions . . . . . . . . . . . 79

Compatibility with Other Systems . . . . . . . . . . . 79

Equipment Purchase . . . . . . . . . . . . . . . 81

Conclusions . . . . . . . . . . . . . . . . . . 81

R E F E R N C E S . . . . . . . . . . . . . . . . . . . . . . . 83

$\begin{array}{llllllllllllllll}A & P & P & E & N & D & I & X & A\end{array}$

T H E P L A N N E R ' S D A T A B A S E . . . . . . . . . . . .

$\begin{array}{llllllllll}\text { A } & \mathbf{P} & \mathbf{P} & \mathbf{E} & \mathbf{N} & \mathbf{D} & \boldsymbol{I} & \mathrm{X} & \mathrm{B}\end{array}$

D A T A S O U R C E D E T A I L . . . . . . . . . . . . . . . 141

Guidelines for Classification . . . . . . . . . . . . 141

Tax Assesвor'g Data Card . . . . . . . . . . . . . 143

B I B L I O G R A P H Y . . . . . . . . . . . . . . . . . . .. .145 
Table 1.--Tax Assessor's Data Fields Used in the Database . . . 13

Table 2.--Additional Data Fields . . . . . . . . . . . . . . . . 14

Table 3.--Sample Planner's Database Record - Foster RI . . . . . 14

Table 4.--Zoning Codes - Foster, RI . . . . . . . . . . . . . . . 18

Table 5.--Standard Rhode Island Property Codes Used in the Planner's Database . . . . . . . . . . . . . . . . . . . 20

Table 6.--Building Grade Codes . . . . . . . . . . . . . . . . 19

Table 7.--Heating Fuel Codes . . . . . . . . . . . . . . . . . 21

Table 8.--Land Use Summary 1990 - Foster, RI . . . . . . . . . . 35

Table 9.--Vacant Land 1990 - Foster, RI . . . . . . . . . . . . 37

Table 10.--Narragansett Electric Company Easements - Foster, RI . . 38

Table 11.--Parcels Owned by Water Supply Board - Foster, RI . . . 38

Table 12.--Housing Characteristics by Grade - Foster, RI . . . . . 40

Table 13.--Residential Heating Types - Foster, RI . . . . . . . . . 44

Table 14.--Heating Types for New Units by Decade - Foster, RI . . . 44

Table 15.--Frontage Buildout Worksheet and Totals . . . . . . . . . 51

Table 16.--Backlot Buildout Worksheet and Totals . . . . . . . . . 53

Table 17.--Population Estimate Based Upon Frontage Lot Buildout . .54

Table 18.--Predicted Number of Additional School-Age Children . . . 57

Table 19.--Vacant Comnercial and Industrial Land in the scituate Reservoir Watershed . . . . . . . . . . . . . 58

Table 20.--Vacant Land Value in the scituate Reservoir watershed . 59

Table 21.--The Average Value of Substandard Lots of Record vs. Unbuildable Land in the scituate Reservoir Watershed . . 61

Table 22.--Vacant Land Purchase Scenario . . . . . . . . . . . . 63

Table 23.--single-Family Residences by Map - Foster, RI . . . . . 65

Table 24.--Two-Family Units by Map - Foster, RI . . . . . . . . . 66

Table 25.-Multi-Family Units by Map - Foster, RI . . . . . . . . 66

Table 26.--Mixed Residential Units - Foster, RI . . . . . . . . . 67

Table 27.--Residential Farms by Map - Foster, RI . . . . . . . . 67

Table 28.--Seasonal Residential Units - Foster, RI . . . . . . . 68

Table 29.--Commercial Property Less Than \$100,000 - Foster, RI . . 68

Table 30.--Commercial Property Greater Than \$100,000 - Foster, RI. 69

Table 31.--Total Industrial Property - Foster, RI . . . . . . . . 69

Table 32.--Cemeteries by Map - Foster, RI . . . . . . . . . . . . 70

Table 33.--Charitable Property by Map - Foster, RI . . . . . . . 70

Table 34.--Church Property by Map - Foster, RI . . . . . . . . . 70

Table 35.--Library Property by Map - Foster, RI . . . . . . . . . 71

Table 36.--Town Property by Map - Foster, RI . . . . . . . . . . . 71

Table 37.--state Property by Map - Foster, RI . . . . . . . . . . 72

Table 38.--Utility Property by Map - Foster, RI . . . . . . . . . 72

Table 39.--other Improved Land by Map - Foster, RI . . . . . . . 73

Table 40.--Vacant Residential Land by Map - Foster, RI . . . . . 74

Table 41.--Farm, Forest and Open Space Land by Map - Foster, RI . . 74

Table 42.--Vacant Commercial/Industrial Land by Map - Foster, RI . 75

Table 43.--other Vacant Land by Map - Foster, RI . . . . . . . . 75

Table 44.--Components of a GIS . . . . . . . . . . . . . . . . . . 80 
Figure 1.--Location of Foster in Rhode Irland . . . . . . . . . . 1

Figure 2.--Map of Foster, Rhode Island . . . . . . . . . . . . . . 2

Figure 3.--Relationship of Planner's Database to Planning Process 26

Figure 4.--Planner' B Database Updating Process . . . . . . . . . . 28

Figure 5.--Sample Database File Card . . . . . . . . . . . . . . . 29

Figure 6.--Land Use Percentages 1990 . . . . . . . . . . . . . . .34

Figure 7.--Average Building Area by Decade - Foster, RI . . . . 39

Figure 8.--Housing Units with Four or More Bedrooms U.S. and Foster, RI . . . . . . . . . . . . . . . 41

Figure 9.--Homes With More Than Two Bathrooms U.S. and Foster, RI . . . . . . . . . . . . . . . 42

Figure 10.--Heating Type Percentages - Foster, RI . . . . . . . . . 43

Figure 11.--Change in Installed Heating by Decade - Foster, RI. .45

Figure 12.--Population Estimate by Number of Persons per Bedroom Foвter, RI . . . . . . . . . . . . . . . . . 47 


\section{The Project Area}

Foster is a rural town in northwestern Rhode Island bordering the State of connecticut and is bounded by the towns of Glocester to the north, scituate to the east, coventry to the south, and Rillingly and sterling, connecticut to the west. Figure 1 shows Foster's location within the state of Rhode Island, approximately sixteen miles west of Providence. The Town's 52 square miles are made up of land characterized by swampy valleys and rocky ridges and is almost entirely covered by forests. The poor soils and other Iimitations to development, such as steep slopes and wetlands, have held land use within the

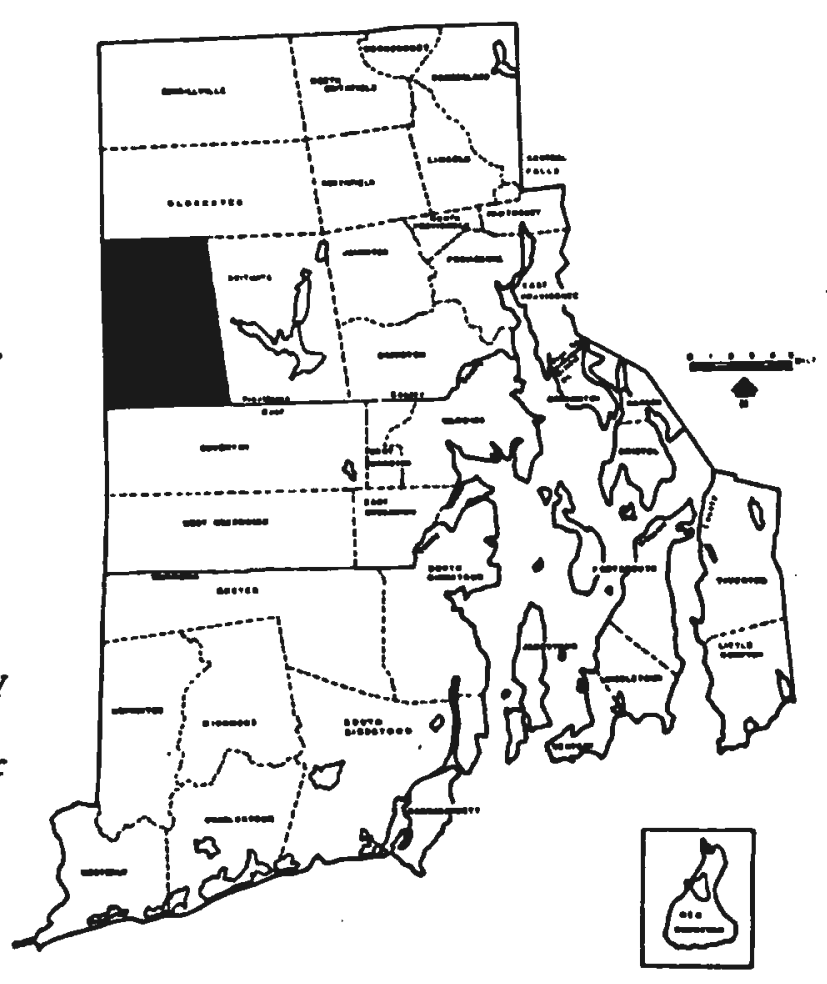
Town to small scale agricultural uses, commercial operations, and single-family residential dwellings (Rhode Island Historical Preservation Commisgion 1982). Foster straddles two major drainage basins contributing runoff to Narragansett Bay and Long Island Sound. Approximately one half of the 
Town drains towards the Scituate Reservoir, which is the primary drinking water supply for the greater Providence metropolitan area. A smaller sub-watershed in the southeastern corner of the Town drains to the Flat River Reservoir, a body of water used primarily for recreation in the Town of Coventry located to the south (Everett 1982).

The major roads and centers in Foster are shown in Figure 2. The topography and soil characteristics of Foster have historically dictated the land use pattern. Because the Town's rivers are essentially headwaters, swift flowing and relatively shallow, development of large industrieg using water power was thwarted. The lack of industry and poor agricultural soils contributed to the Town's late settlement in comparison to the surrounding towns. The population grew rapidly until 1820, then declined when opportunities for agriculture in the western states and industry in surrounding towns enticed people to move away. The period from the 1830 to 1950 was a time

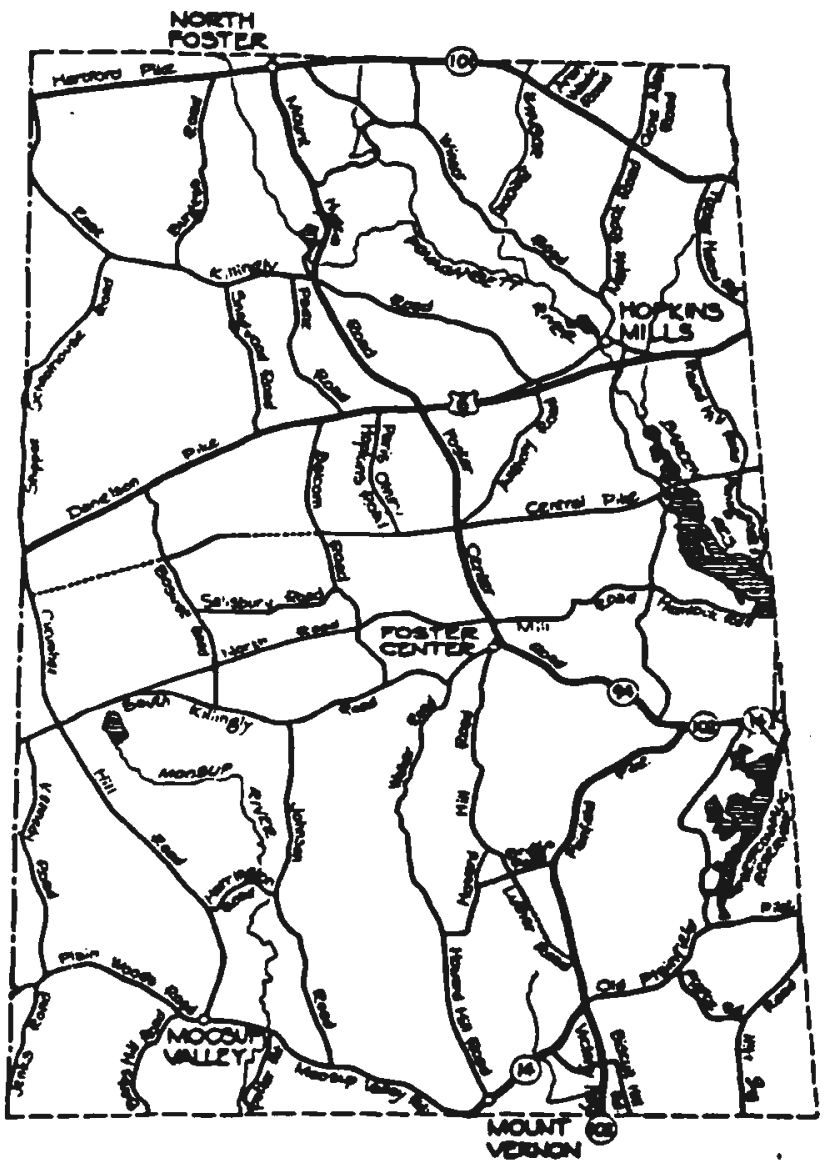
of stagnation.

Figure 2:--Map of Foster, Rhode Island

It was not until 1950 that Foster resumed growth. This was perpetuated by the availability of relatively inexpensive land and 
Foster's rural character, lured people to move from the greater Providence area (Everett 1982).

A steady influx of new residents in the 1980s prompted the Town to enact a strict large lot zoning ordinance requiring a minimum of 5 acres per building lot for the purpose of preserving the rural character. With the hope of directing growth in a more responsible manner, the Town has recently employed a part-time planner. As Foster begins the update of its comprehensive plan, the planning process continues to evolve.

At the core of the planning process is the gathering, analyzing, storing and distribution of information. The collection and manipulation of data should be given a high priority. Modern microcomputer technology provides the small town planner with the means to manage large amounts of data quickly and efficiently.

Towns must maximize the impact of every public dollar spent. This requires accurate and timely information. A computer system can provide the means for the pooling of this information, its analysis, and its effective use (Kops et al. 1986). Improved handling of data for planning purposes will help achieve the Town's objectives.

Foster is in a unique position to take full advantage of the opportunities afforded by an integrated information database. There is a wealth of information available to decision-makers in the Town, but no coordinated system for utilizing it. An informational database will allow the Town to monitor and evaluate the parcel-specific impacts of development and change. 
The Project Concept

This study proposes to implement and test a computerized

informational database for a small town, Foster, Rhode Island. It will

provide a valuable tool for the rapid retrieval, organization, and analysis of information essential to rational and timely decisionmaking. The database will integrate information from various local, state, and federal sources for a comprehensive level of analysis that would otherwise be impractical.

This study has been organized into five components. This chapter provides a general background of Foster and the rationale for the study. Chapter Two details the data collection process and the strengths and weaknesses of the data sources. Chapter Three contains detailed instructions and suggestions for database management. Chapter Four includes a description of existing housing and land-use conditions in Town. Additionally, the Project Team demonstrates examples of database projection techniques and hypothetical scenarios for which the database could be used. Recommendations for further study are included in Chapter Five.

Hard-copy of the database in the form of $4 \times 6$ index cards has been provided to the Town of Foster, as well as a computer diskette copy that is compatible with the Town's current system. The index card data file is duplicated in a list format found in Appendix $A$.

Martin Meyerson (1956) proposed building a "middle-range bridge" for comprehensive planning. The middle-range bridge seeks to define a middle ground between comprehensive planning which is not responsive enough to the immediate needs of the community, and project planning, 
which has no logical framework for long-range decision-making.

Meyerson envisioned five expanded functions for planning agencies:

1. A Central Intelligence Function

2. A Pulse-taking Function

3. A Policy Clarification Function

4. A Detailed Development Plan Function

5. A Feed-back Review Function.

Implicit in this scheme is the municipal planning authority's ability to collect, analyze, and disseminate information. When Meyerson proposed these additional functions, only cities with large planning staffs could possibly be expected to handle such an enormous task. Since then however, the advent of high-speed microcomputers and relatively user-friendly computer filing software, spreadsheet software, and data analysis packages allow even the smallest planning staffs the ability to handle the mechanics of data collection and analysis with ease.

Surprisingly many large city and town planning staffs have not yet taken advantage of the microcomputer's ability to store, sort, and analyze data. Towns and cities typically collect a significant amount of accurate and valuable parcel-specific data for the purpose of levying property taxes. At least two of Rhode Island's largest cities, Providence (Winsor Associates 1990) and East Providence (CPAD 1989) have yet to integrate the wealth of data available from the Tax Assessor's records into a usable planning database.

The Tax Aвsessor's database provides the framework around which the Foster Planner's Database will be built. The Tax Assessor's database typically includes dozens of information categories, or "fields" pertaining to each parcel of land in Town. Several of these fields can be of great interest to the planner. The lot size, lot frontage, zoning 
type, and current use code, for example, provide a useful synoptic view of the current land-use in a town without performing a tedious windshield survey. Unfortunately, until now, if this information were desired in a usable form one would have to sort through each of the parcel cards. A simple query like, "How many parcels of land in Town are zoned commercial, but are currently vacant", might take hours or days to answer. The planners database makes this type of information available almost immediately.

An important aspect of a planning information system is the source, scale, and detail of data. Information for the Planner's Database will be collected and recorded on "lot-specific" basis, allowing for analysis at the most detailed level. The lots can be aggregated into plats, watersheds and planning districts, to name just a few possibilities, to allow for logical analysis at many levels.

The Tax Assessor's database is frequently kept on a computer. Why then couldn't the planner simply access the information through the assessor's computer? Most often the Tax Assessor's database is created for a single purpose - to calculate and mail tax bills. The data fields of most interest to the planner are often inaccessible. In addition, the planner might want to integrate other information which is not available in the assessor's database such as watershed location, hydric soils, and natural or higtorical value. 
The Planner's Database for Foster, Rhode Island will be

demonstrated in three basic fashions,

1. A descriptor of current conditions

2. A forecasting tool

3. A problem solving tool for hypothetical situations that may arise in the future.

Each demonstration will include a brief narrative describing its utility and methodology as well as a sample output from the database.

Our intention is not necessarily to demonstrate every capability of the database, but to provide examples of how it can be used. Future applications are limited only by the imagination and creativity of the user. Above all, the database is not planning, it is simply one planning tool which if used properly can provide rapid and accurate information for more informed decision-making.

\section{Computer Database Capabilities}

A computerized database is nothing more than an electronic filing system. The computer allows for the database to be manipulated, sorted, and updated faster than ever possible with a standard manual filing system. The ease of data aggregation and output allows for a level of analysis that would otherwise be impractical.

Each record in a database is analogous to a file card in a manual filing system. In the Planner'g Database each lot in Town is represented by a record. The information on each record is ordered into data fielda. The data fields contain the lot specific information collected by the Project Team for each record. Each record has the same number of fields; each with its own unique set of data.

Each field can be accessed separately, or in conjunction with any 
of the other fields. A selected group of records can be subtotaled or printed according to criteria selected. For instance, with the Planner's Database it is possible to print out a list of all lots included in Assessor's Map 10. The output criteria can be much more complicated, and therefor more selective for many given purposes. Chapters Three and Four provide further details as to how data fields can be accessed to provide useful information.

The database provides the capability to perform three major functions; sorting, selection, and output. Used together, these three functions enable the analyst to manipulate the database efficiently to derive useful information.

The database's sorting function allows the analyst to sort the database in any number of orders. The Planner's Database will most often be sorted in Map and Lot order; meaning that the records will be sorted in ascending order from the lowest Map and Lot number to the highest. This is intuitively the most logical ordering of the database, and provides the simplest order for locating records. It is; however, not necessarily the most useful ordering of the database. As mentioned earlier, the database can be accessed and manipulated by any one of the data fields. For example, it is possible to sort the database in order of assessed building value. In this way it would be possible in a matter of minutes to determine the high, low, and median value of homes in Town. A variation on this sort would be to order the database first by Map number and then by assessed value. Then it would be possible to determine the high, low, and median house value by Assessor's Map number. Any number of sorts can be performed on the database to 
rearrange the data for whatever purpose using any combination of the data fields.

The database's selection function allows the analyst to select a record, or group of records based upon selection criteria applied to the data fields. In its simplest form, the selection function can be used to locate an individual record by Map and Lot number. By entering a particular Map and Lot number into the selection criteria, the database will search all records until it finds a match. Within moments, the desired record will appear on the screen along with all of its data field information. The selection function can be used on much more complex (but no more difficult) searches. The database can be instructed to search for all instances of records where the asgessed value is greater than $\$ 50,000$, but the lot size is smaller than ten acres. Again, almost any variation imaginable can be used to select records. The database will search for all records that meet the selection criteria, and by using a few simple commands, the analyst can total and/or subtotal the selected records.

A database's output function enables the analyst to display the entire database, or just selected records or fields in various mediums. The analyst may chose to display the output directly on the computer screen, to the printer, or saved to a computer file. Each output mode has its own advantages and disadvantages. Displaying the output on the computer screen is an ideal way to check output before committing it to print; however, once the computer is turned off, or the screen is rewritten, the output is lost (until that particular report format is duplicated). Printing the output allows the analyst the opportunity to 
review "hard copy". The printout can be taken from the office and ghared with others who do not have access to a computer. One disadvantage of "hard copy" output is that once it is printed, it cannot be further manipulated with the computer or accessed by other computer software programs. Outputting the selected data to a file is a technique that many experienced computer users find extremely flexible. The data can be easily read or imported into other computer software packages, such as word processors, spreadsheets, or statistical packages. Where the database management software is best suited for updating, managing, and selecting records, the other software packages are best suited for their individual purposes. The bulk of this report, for instance, was written with a word processing software package, with much of the data imported from the database either directly, or through a spreadsheet package where tables and graphs were created.

There are many computerized database management software programs available on the market. They can all perform basically the same functions. They are; however not all created equal. The price, complexity, and capabilities differ considerably. The Project Team determined that the database management software package selected for the Planner's Database should exhibit all of the following characteristics to the highest degree possible:

1. It should be compatible with the Town of Foster's current computer hardware

2. It should be compatible with the Town of Foster's existing word-processing software

3. Conversions between the database and other software should be easily accomplished

4. It should be relatively simple and easy to learn

5. It should be inexpensive.

The Project Team selected the PC-File brand database management system 
because it fulfilled all of the proposed criterla to a very high degree. PC-File will run on the Town's current computers. The Town Clerk currently uses an IBM XT clone with 640 megabytes of RAM and a 20 megabyte hard drive. The Tax Assessor uses an IBM 80386 microprocessor clone with 1 kilobyte of RAM and a 40 megabyte hard drive with tape back-up. PC-File will run efficiently on either of these machines. PC-File is compatible with the Town's standard word-processing package. The Town clerk currently has the WordPerfect 5.0 brand wordprocessor installed on the administrative computer. Conversions between the PC-File and WordPerfect 5.0 are built into each software package, greatly simplifying the transfer of data from one software package to the other.

In the experience of the Project Team PC-File is by far the simplest database package to use and learn. All sort, search, and output commands are easily accessed through interactive menus such that it is unnecessary to understand or memorize complicated commands.

PC-File was also the least expensive database management software package of those considered. The price is less than a third of other comparable database packages. Not a small fact to be considered in the Project Team's budget, or the budget of a small town. 


\begin{abstract}
This chapter outlines the data collection process and provides a detailed description of the data fielda collected for the Planner's Database. The data collection process involved incorporating Town Tax Assessor records with other data compiled by the Project Team to construct the database. In the Data Field section each field will be explained individually as to how it was originally collected, how the Project Team further manipulated the data field, and its underlying strengths and limitations.

Data collection
\end{abstract}

The Foster Tax Assessor records are the primary data source for the Planner's Database. The data is reasonably current, as the most recent revaluation of property was August, 1989. The revaluation was contracted out by the town to MMC Inc., a professional property valuation company located in Chelmsford, Massachusetts. MMC Inc. used a standard replacement value method to assess buildings and other real property in town. Current market value for land was determined and applied to each parcel individually, taking into consideration such variables as suitability for further subdivision and suitability for development. Specific details as to how each data field was collected and interpreted by MMC Inc. are available in the evaluator's guidebook, "Foster, Rhode Island, Fiscal Year, 1989, Residential Manual", a copy of which is available on file at the Foster Town Clerk' office. 
In determining real property values, MC Inc. collected many technical detaila regarding each parcel and building in town that may be of great use to planners. A sample assessment data card used by MMC Inc. in the Auguat 1989 revaluation for Foster is included in Appendix B. Table 1 shows the fourteen data fields that the Project Team selected from the Tax Assessor's database that would be of the most use in the Planner's Database.

Table 1.--Tax Assessor's Data Fields Used in the Planner's Database

\begin{tabular}{llll}
\hline \hline & & \\
1. Map and lot description & 8. & Occupancy \\
2. Land Value & 9. & Heating System Type \\
3. Building Value & 10. & Number of Bathrooms \\
4. Lot Size & 11. & Number of Bedrooms \\
5. Land Use & 12. & Total Number of Rooms \\
6. Building Condition & 13. & Building Age \\
7. Number of Stories & 14. & First Floor Square \\
& & Footage
\end{tabular}

The exclusive purpose of Tax Assessor's system is to update property value information and to mail tax bills. As a result, accessing and manipulating data fields within the Tax Assessor's computer system is unwieldy, if not impossible. For this reason, it was necessary for the Project Team to manually extract the fourteen data fields from the hard copy file cards for each of the 2,256 property files. The data was then entered into the Planner's Database, using the PC-File brand database management software.

As valuable as the Tax Assessor's gystem is, it does not provide all the information needed by planners. To augment the Assessor's data, the Project Team collected a number of additional data fields. Zoning, lot frontage, watershed and wetlands information were collected on lotspecific basis to enhance analysis capability of the Planner's Database. 
The additional data fields and their sources are shown in Table 2.

Table 2.--Additional Data Fields

\begin{tabular}{ll}
\hline Data Field & Primary Source \\
1. Zoning & Official zoning Map \\
2. Lot Frontage & Assessor's Map \\
3. Watershed & USGS Topographic Maps \\
4. Wetlands & USGS Topographic Maps \\
\hline
\end{tabular}

Table 3 is a sample of one of the 2,256 data records in the Planner's Database. The record appears just as it will when accessed through the PC-File database management software.

Table 3.--Sample Planner's Database Record - Foster RI

Abbreviated titles are used for

each of the fields. Each of the

fields presented can be easily MAP

modified, manipulated, or up-

dated as necessary.

Each parcel of land in

Foster has at least one record.

Each record consists of the

data fields shown in Table 3.

If a particular field does not

apply to a given parcel, it has

LOT

[1]

SUB

[2]

BLDG VALUE

[A]

PROP VALUE

[67.9]

ACRES

[53.4]

USE CODE

ZONING

$[5.5]$

GRADE

[1]

TTORIES

OCCUPANCY

HEAT TYPE

BEDROOMS

BATHROOMS

TOTAL ROOMS

YEAR BUILT

[1]

[3]

[2]

[1]

[2]

[4]

[2]

[8]

SQFT

[1952]

FRONTAGE

[1.3]

WETLANDS

[450]

been left blank, or assigned a

WATERSHED

[1]

[ ]

zero value.

Several properties in Foster have more than one significant

dwelling unit. In this event the Project Team created a secondary record to supplement the primary parcel record. The secondary record for an 
additional building on a parcel contains virtually the same fields as the primary card, with two important differences; 1. the building fields are unique to the second building, and 2 . the land value and acreage fields are zero to avoid the double counting of land area and value.

\section{Data Fields}

The fourteen Tax Assessor data fields and four additional data fields comprise the framework around which all data manipulation and forecasting is accomplished. It is important to understand the underlying strengths and weaknesses of each of the data fields as they were collected for the Planner's Database. Each data field will be explained individually as to how it was originally collected by the primary data source, how the Project Team further manipulated the data field, and its underlying strengths and limitations.

Map and Lot Description

The Map and Lot Description actually consists of three separate data fields - Map, Lot, and Sub-lot. The Assessor's Map divides the town into twenty-two numbered Maps. The first eighteen of which are generally the same size and have anywhere from fifty to eighty lots. Maps number nineteen through twenty-two constitute the historical nodes, or village centers, and are therefor smaller in area, but do not necessarily have fewer lots or buildings than the larger Maps due to generally smaller lot sizes.

The Map, Lot, and Sub-lot numbers are assigned by the Tax Assessor for each parcel of land in town. The complete list was verified by mac Inc. prior to the revaluation in August, 1989. The Project Team entered 
these flelds exactly as determined by MMC Inc. with minor adjustments to account for land sub-divided since Auguat according to the Planning Department's records of approved subdivisions.

The Tax Assessor's database, generated by MAC Inc. apparently has difficulty dealing with the alpha-numeric ordering of "mixed" fields. An example of a mixed field is "Lot 14AI". Instead of ordering this lot between "Lot 14A" and "Lot 15", for example, the Assessors database will in effect reject the mixed numbering system and send " $14 \mathrm{Al}$ " to the end of the list. The Project Team's database has gotten around this data quirk, and all Maps, Lots, and Sublots can be arranged in proper alphanumeric order. Unfortunately, this can cause some confusion when comparing the Tax Assessor's alpha-numeric listing to the Planner's Database.

The alpha-numeric system difficulties are further exacerbated by the lack of a consistent numbering scheme in town. New sub-division numbering is apparently left up to the land owner, or map surveyor. For example, Map 17, Lot 45 might be sub-divided into three lots by one person as Lots 45, $45 \mathrm{~A}$, and $45 \mathrm{~B}$. Another sub-divider might chose 45 , 451 , and 452 . A consistent numbering scheme would be helpful in the orderly division and recording of sub-divisions.

Land Value

The Land Value data field is taken directly from the Tax Assessor's parcel card. The market value of land was determined by MMC Inc. using property size, property characteristics, and potential property uses. Real property in Foster is taxed at a 50 valuation. The land value data collected by the Project Team represents 100 valuation. 
The Project Team recorded values for both land and bulldings in thousands of dollars, with one decimal place accuracy. Where necessary, the MC Inc. valuation was rounded up or down as appropriate. This was only necessary for a very few entries, as the Msc Inc. valuation was for the most part expressed in hundreds of dollars.

Land values can change dramatically over time. The land values in the Planner's Database should be used carefully. However, assuming land values in Foster rise generally evenly across the board, the land value data can be used effectively to make comparisons between areas in town, between individual parcels, or as a relative indicator of property worth.

If needed the actual current land values could be estimated using an correction multiplier determined by comparing assessed value to actual sales data. See Chapter Four for further details. Building Value

Like the Land Value data field, the Building Value Field was extracted directly from the Tax Aввевsor's database. For ease of data entry and to save computer file space, the values were entered in thousands of dollars with one decimal place representing hundreds of dollars. The figures collected represent 1008 valuation. MMC's method for determining market value is based upon a replacement cost method that takes into consideration the building grade, or quality of workmanship, type of construction, building style, the number of bedrooms, bathrooms, and total rooms, the effective year of construction, the total square footage, and any other special features such as brick fireplaces. 
Lot size

Lot sizes were collected from the Tax Assessor's database in acres. MMC Inc. collected the original data from the previous set of valuation cards, which have been updated continuously since the last valuation. The lot size data are considered to be fairly accurate. Still, many properties have not been surveyed in many years and when modern surveys are made, differences up to an acre or more are not uncommon (Smith 1990). As with all fields, an effort should be made to update the data as new and better information becomes available. The method for updating records and individual fields will be discussed more fully in Chapter Three.

zoning

The appropriate zoning

category was determined for every

lot by comparing the Town of

Foster official zoning Map to the

Tax Assessor's maps. Several

zones, particularly the Highway

Commercial zone along U.S. Route 6 , cut across property lines such that
Table 4.--zoning Codes - Foster, RI

CODE DESCRIPTION

1. Regidential/Agricultural

2. Senior Citizen Housing

3. Neighborhood Commercial

5. Manufacturing / Industrial
4. Highway Commercial

a parcel might be partially in the Highway Commercial zone, and partially in the Residential/ Agricultural zone. A parcel which is ten acres might only have four acres in the Highway Commercial zone. In all cases, the higher use category was assigned to a property which included more than one zone. Table 4 shows the codes which were assigned to each zoning classification for the purpose of the Planner's Database. 
Land Use

The Land Use data field describes the appropriate use of the parcel as determined by MMC Inc. from the existing Tax Assessor's database and from the individual site visits accomplished in August, 1989. The code represents the most accurate description of the current use of the property. Table 5 on the following page is an abbreviated list of land use codes which includes all codes utilized in the Planner's Database. The standard Rhode Island coding system for land use was utilized.

Building Grade

This field was collected by MMC Table 6.--Building Grade Codes Inc. as a measure of a building's relative condition and level of CODE DESCRIPTION welative condition and level of 1 workmanship. The figure was used by MMC Inc. as a correction factor to adjust 4 the market value of a building either up 6 or down, depending upon ito condition 8 or down, depending upon its condition 9 and cuality of construction. The Project 10

Minimum Below Average Average Average +10 Average +20 Excellent Excellent +10 Excellent +20 Luxurious Luxurious +

Team felt that this data would serve

well as an indicator of a building's condition and the relative spatial distribution of average, above average, and below average housing stock in town.

The Building Grade codes were taken directly from the Tax Assessor's database and the coding system follows the MC Inc. method exactly. Table 6 shows the coding system used in the MMC Inc.. Appraiser's Guide. An explanation of the grade codes is in Appendix B. 


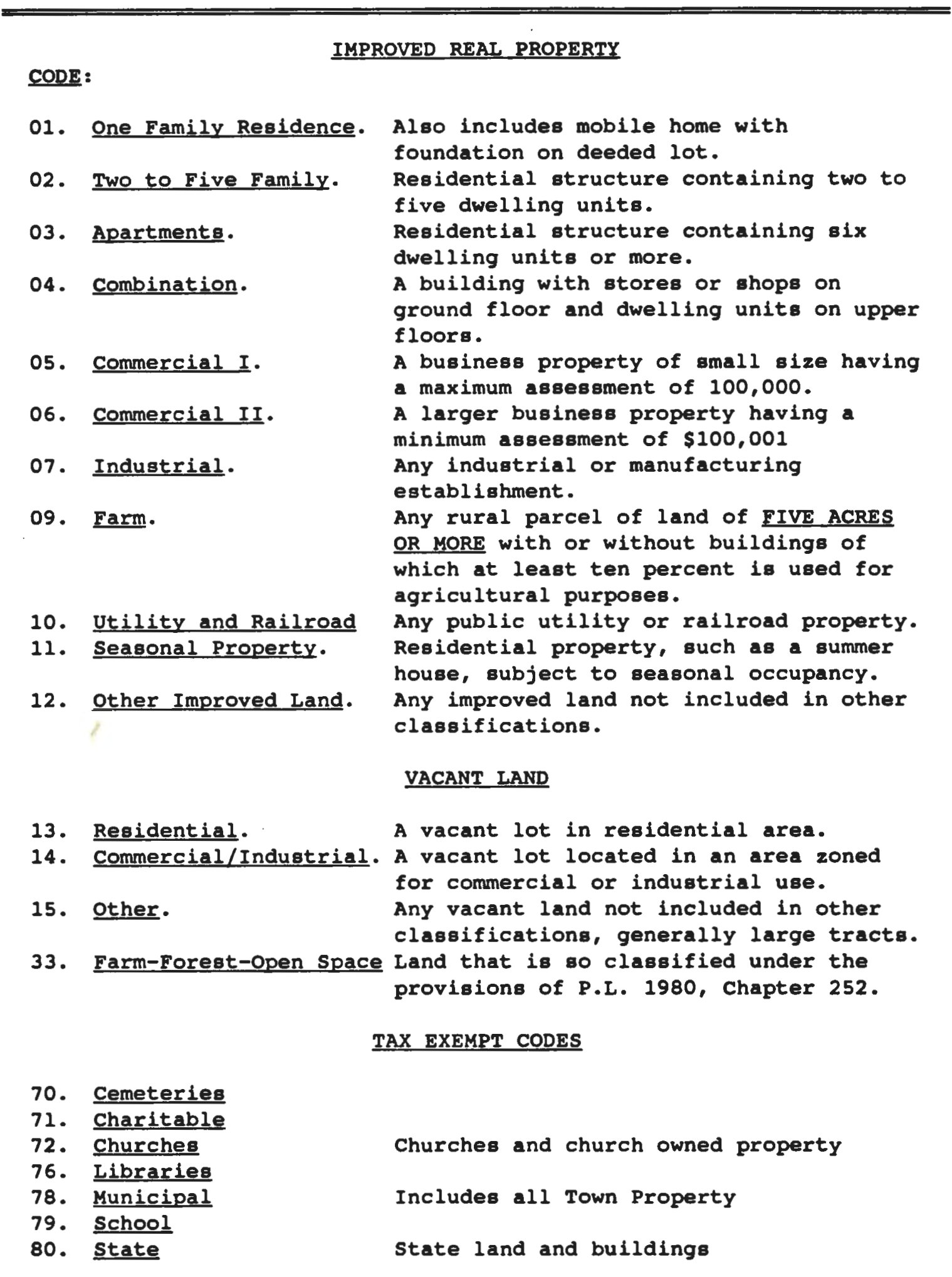


Number of stories

MMC Inc. recorded the number of stories for each building in town. The Project Team determined this information would be necessary to estimate the total living apace for each building, aince Mac Inc. only collected the firat floor square footage for each building. Although not nearly as precise as might be desired, multiplying the first floor square footage by the number of stories reaulta in an approximation of the total square footage of a building. The square footage calculation is intended to be used for comparison purposes only, and should not be interpreted as an accurate representation of building gize.

occupancy

MMC Inc. determined the number of living units included in each housing structure. In general, a second unit was considered to exist when an area of the house had access to a separate kitchen and bathroom facility. Occupancy for apartments or boarding rooms was determined exclusive of kitchen and bathroom facilities when obvious signs of partitioning existed.

Heating Fuel Type

MMC Inc. determined the primary

Table 7.-Heating Fuel Codes heating system type for each building in

\begin{tabular}{ll}
\hline \hline CODE & DESCRIPTION \\
0 & None \\
1 & Wood or Coal \\
2 & Oil \\
3 & Gas \\
4 & Electric \\
5 & Solar \\
\hline
\end{tabular}
heating system, the MMC Inc. appraiser recorded the more predominant, or efficient gystem. 
Table 7 shows the codes used by MMC Inc. and the Planner's Database to describe the heating fuel type. The Project Team felt this information might be useful in the event of another "energy crisis" such as in the early 1970 s when all town's were required to develop energy conservation plans.

Number of Bathrooms

The number of bathrooms was collected by MMC Inc. for each building in town. The figure represents the total number of full and half-baths in a structure. It is therefor impossible to determine, for example, if two baths are actually two full baths, or one full bath and two half baths. A full bath typically includes tollet, a sink, and a bath or shower unit. A half bath includes only a toilet and a sink. Regardless, the field was considered to be an important indicator of relative housing value, and also as a possible multiplier for septic system waste loading calculations.

Number of Bedrooms

The number of bedrooms was collected by MMC Inc. for each dwelling unit in town. Bedrooms in the basement are not included in the total figure. Also, any bedrooms that have been temporarily changed into a den or dining room are counted as bedrooms (MMC Inc. 1989).

The Project Team included this field in the Planner's Database as an indicator of relative building worth, and as a possible estimator of population. (See Chapter Four)

Total Number of Rooms

The total number of rooms, as originally collected by MC Inc., was included in the Planner's Database. The total number of rooms 
includes all heated rooms other than bathrooms. The total does not include low quality or semi-finished rooms below grade.

Building Age

The building age is the estimated year of original construction. The dates were determined or estimated through various techniques; existing Tax Assessor records, plaques on historic homes, opinion of the homeowner, or an estimate by the appraiser. Building ages for historic homes and newer homes are most likely the most accurate. The age of historic homes have been painstakingly researched and documented. Unfortunately, old houses with major renovations or additions were considered to have been built new as of the date of new construction. The age of homes built during this century have been continuously recorded or are personally known by the owner or neighbors. The ages of homes built during the 19th Century are the most suspect. Evidence of this is the large number of homes reported to have been built in 1800 . This is either the result of an enormous building boom during that year (unlikely) or the result of "best-guesses".

First Floor square Footage

As mentioned in the description of the Number of stories field, the best available building square footage data collected by MMC Inc. was the building's first floor square footage. This figure is used by the Project Team to estimate total building square footage by multiplying the first floor square footage by the number of stories. It can also be used as a measure of the buildings' impervious area for stormwater runoff calculations, since it approximates the building "footprint" 
Lot Frontage

The approximate lot frontages were collected by the Project Team from the Tax Assessor's plat maps. Many parcels have lot frontages indicated directly on the map. These figures were used when available. For the large number of lots that lacked frontage data, the Project Team scaled approximate frontages directly from the maps. While this is not considered an ideal method for determining and accurate frontage, it was the best method available, and should not result in an appreciable error for the purpose the data was collected. The frontages were collected to determine a lot's eligibility for further subdivision. Since the minimum lot frontage in Foster is 300 feet, errorg within a few feet per parcel should not effect the outcome noticeably.

Watershed

The Profect Team used the USGS Topographic maps to determine the boundary of the Scituate Reservoir (the watershed of a public water drinking supply that serves over sixty per cent of Rhode Island) in the Town of Foster. The watershed boundary was superimposed upon the Tax Assessor's plat maps so that all lots that lie within the scituate Watershed could be identified. Lots in the watershed are marked with a "1" in the Watershed field.

Wetlands

The presence of wetlands on a parcel was determined by the Project Team by overlaying a hydric-soil template derived from the Rhode Island Soll Survey on the Tax Assessor's Maps. The presence of wetlands on a parcel is indicated by a "1". The indication of wetlands on a parcel is not to be considered definitive. The scale of the soll survey and 
Assessor's maps is such that precise accuracy 18 impossible. The database can act as a reasonable guide as to the presence of wetlands in a particular area; however, site specific surveys are necessary whether or not the database indicates wetlands. 


\section{A T A B A S E A D M I N I 8 T R A T I O N}

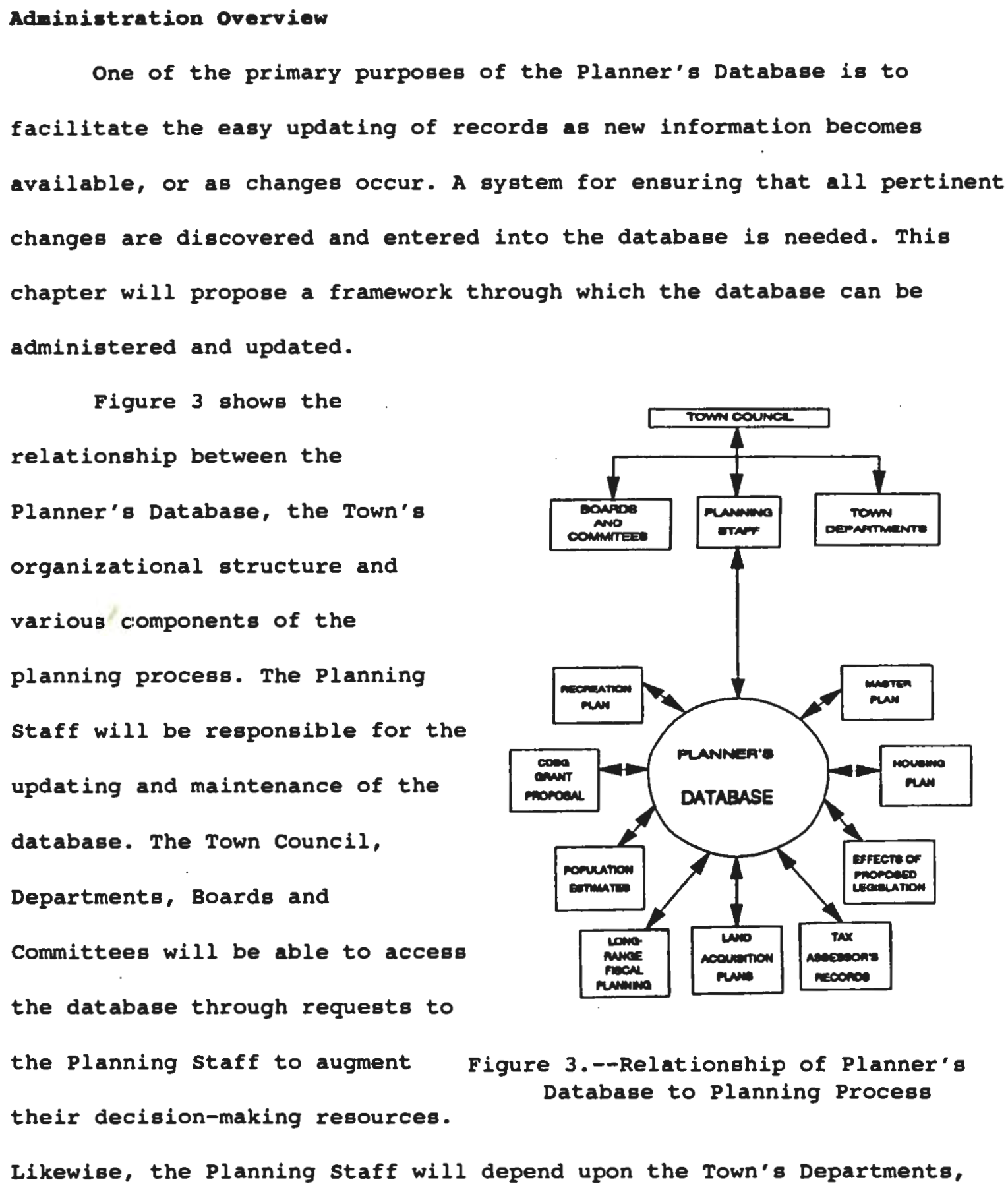


Boards and Committees for input to update the database.

The administration and updating of the database should not be unwieldy or overly time-consuming. One of the purposes of the database is to save time, and streamline the planning function. It would not be useful if the administration of the database consumed more time than it saved.

The careful updating of the database will serve yet another purpose. By periodically saving the database and archiving the diskette, a permanent record of the present condition of the town can be preserved. By constantly updating the records, a time series of data will eventually be available to supplement the planner's projection capabilities. Annual "gnapshots" of the town's condition will enable the planner to identify changes in the fabric of the town's makeup that might otherwise have been imperceptible.

\section{Update Procedure}

Changes to the database may come from many sources. The primary sources of change will most likely be the result of:

1. Building demolitions
2. New building construction
3. Loning changes
4. New divisions of land
5. Corrections

Most of the changes to the database will come from new construction and divisions of land.

Figure 4 demonstrates the basic permit procedure and its relationship to the updating of the Planner's Database. For example, when an application for a building permit is filed, the Planner's 
Database can be used by the Building Inspector to help determine the property's suitability for construction. When the new building is completed, the Building Inspector will issue a certificate of occupancy and update his files. It is recommended that the Planning staff requests on a quarterly basis all new certificates of occupancy issued. Upon notification, the Planning staff should request the new buildings' valuation data from the Tax Assessor. This data should complete the information necessary to update the new property.

Another opportunity for the maintenance and updating of the database is on the occasion of parcel subdivision. Applications for the division of land will involve inputs to and from the Planner's Database. To ensure conformance with relevant zoning and subdivision ordinances, an initial application can be reviewed for general suitability by accessing the Planner's Database information fields such as frontage, acreage, zoning, wetlands, and watershed. Once a

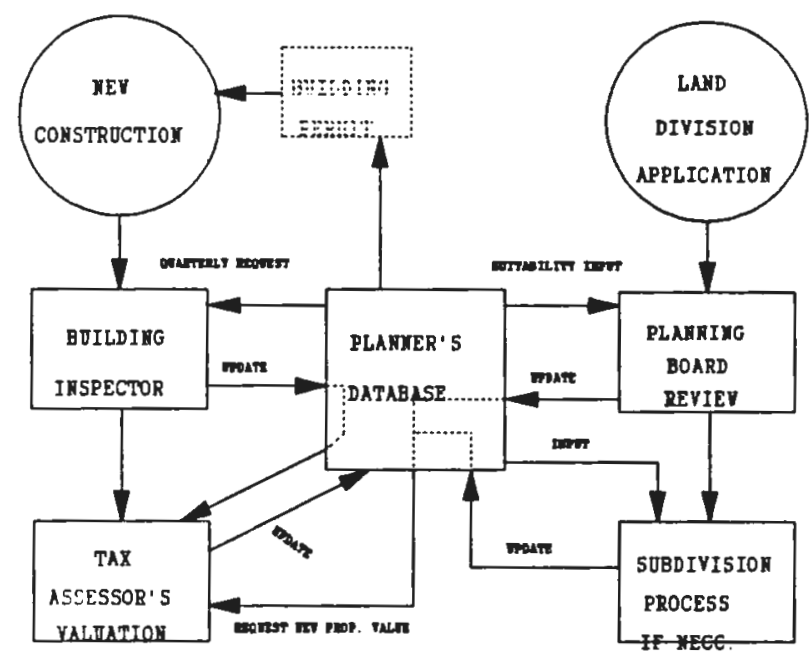
subdivision of land is approved, Figure 4.--Planner's Database Updating Proces8

the Planner's Database will need to be updated to reflect the new information. Again, the Tax Assessor must be contacted to provide the new assessed value for the newly divided parcels.

New records will need to be started for lots that are created. Acreage and frontage will need to be subtracted from existing lots which 
are further divided. It is recommended that the hard-copy index card file provided as part of this project be used to record changes to records as they occur. Records that are changed should be temporarily "flagged" until the appropriate computer entries are made. Newly created parcels would be designated with a temporary hand-scribed index card with all available data. Figure 5 depicts a sample file card generated by the Project Team for the Town of Foster for the convenient updating and maintenance of the Planner's Database.

Map: 1 Lot: $2 \mathrm{~A}$

BLDG VALUE 67,900

BLDG. GRADE 3

STORIES

OCCUPANCY

HEAT TYPE

BATHROOMS

BEDROOMS

TOT ROOKS

YEAR BUILT

SQ. FOOTAGE
4

2.0

8

1952

1,300
Use Code: 1

PROP VALUE

ACRES

FRONTAGE

WETLANDS

WATERSHED

NOTES : zoning: 1

53,400

5.5

450

1

Figure 5.--Sample Database File Card

The typical division of land will involve two separate operations: the modification of the existing master lot and the creation of new records for the newly created lots. The first step in modifying the Planner's Database is to make sure that the hard copy index card is properly filled out with all the information that is needed the records. 
In PC-File, a record is modified by first locating the appropriate record and calling it up on the screen. From PC-File's main menu, the operator simply selects "Find a Record" by pushing either the "F2" key or "F". PC-File then asks how the operator wishes to find a record. The simplest method for finding a specific Map and Lot is through a "Search" - press the "S" key to access PC-File's search mode. PC-File will then ask if the operator wishes to perform a complex or a simple search. A complex search (actually complex only in name, not execution) is used for specifying limits or ranges for records to be selected and is more often used for data analysis. The simple search is well suited for finding a specific Map and Lot record. Select the "S" key for a imple search.

PC-File will then display a blank record. The operator need only enter Map and Lot number of the desired record in the appropriate blanks and press the "F10" key to begin the search. When PC-File finds a match for the search criteria, the record will be displayed on the screen.

If for some reason it is not the correct record, the search can be continued, or a new search with new criteria can be executed by presing the appropriate menu key as shown in the inset command box.

When the proper record is displayed on the screen press " $M$ " for modify (also from the inset command box). Any or all of the fields can now be modified by using the arrow keys to position the cursor on the field to be updated and typing in the new data.

When the record has been properly updated and checked, press the "F10" key to finish modifying. Now press " $Q$ " to quit the find function and return to the Main Menu. 
Now all that remains is to add new records for the lots that were created. This operation is much simpler than modification. From the main menu, simply pregs the "FI" key or "A" to add a new record. PC-File will immediately display a blank record and allow the operator the opportunity to type the appropriate data in the blank fields.

Use the arrow keys to move from field to field to enter data and to correct any mistakes. When the data is entered correctly, press the "F10" key to add the record to the database. PC-File will give you a chance to decide whether or not you really want to add the record check the data once again and select "Y" for yes - add the record. Continue adding records until you are done.

In order to leave PC-File's add a record mode, the operator must first add the final record and, without entering any data in the next blank record, press the "F10" key. PC-File will automatically return to the Main Menu.

The on-screen menus frequently provide enough information to solve almost any problem or question the operator might have. If the operator needs additional help, the "Alt-H" keys (press the "Alt" and "H" keys simultaneously) can be pressed for detailed on-line help that is specific to the operation, or screen currently displayed. 
This chapter demonstrates some of the capabilities of the Planner's Database. The chapter is divided into three sections; a description of Present Conditions, a demonstration of Forecasting Uses, and a scenario Building section that illustrates potential situations for which the database might be used.

The Present Conditions section describes the current land use, a vacant land summary, basic housing characteristics, and a summary of home heating energy uses. Knowledge of the current conditions in Town is vital to the planning process since it gives the planner a baseline for informed decision making. This section is not all-inclusive, but provides a demonstration some of the inventory capabilities of the Planner's Database. Many other combinations of current conditions are possible depending upon the planning situation.

An important responsibility of the planner is the ability to identify trends and predict future requirements. The Forecasting Uses section provides demonstrations of how the Planner's Database can be used to predict population, housing, and fiscal needs. The database is used to identify past trends. These trends are analyzed and projected to predict possible future conditions. Various parameters and techniques can be applied to determine best, worst, and most likely scenarios. The Scenario Building section highlights the flexibility and utility of the Planner's Database in hypothetical situations. The 
potential effects of proposed legislation is demonstrated using the Scituate Watershed Management Plan as an example. The database is used to identify the location of a hypothetical school/recreational complex. Finally, the benefits of periodically "archiving" the current condition of the Town through the Planner's Database are discussed.

\section{Present Conditions}

Land Uge Summary

The land use pattern within a community is framed by its historical development, nature of its land, political and regulatory structure, public agencies, financial agents, and economic conditions. For the Planner to determine where the Town is going in the future, an accounting of the present scheme of land use is required. Evolution of changes in the land use pattern can be noted by making comparisons to points in time in the past. By evaluating the changes over time and the forces mentioned above, trends are identified and projections can be made (Chapin Kaiser 1985). The Project Team has accounted for the various lands use within Foster for 1990.

Land uses within the town of Foster range in intensity from single family residential to industrial. Land used for residential purposes constitutes the largest percentage of all types of land use with 17,162.5 acres. Commercial and industrial uses account for 593.9 acres, the second largest use of land. The remainder of the Town's land is used for municipal and state purposes, utility owned land, cemeteries, churches and conservation land. Close to 697 acres are devoted to these other uses. A significant portion of Foster remains vacant. Vacant land 
accounts for $12,368.0$ acres. These totals allow the planner to calculate the percentages of land use in Foster. Figure 6 indicates the percentages of land use within the Town for 1990. Looking at the specific uses

within the above land use groupings, such as single-family regidential, cemeteries, and Town owned land, gives a more detailed indication of the predominant land uses in Foster. The basic land use categories are

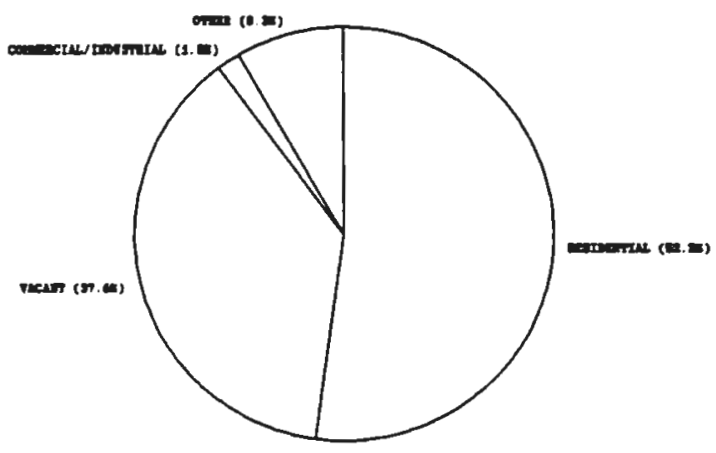
further disaggregated by acreage and Figure 6.--Land Use Percentagea 1990

percentage totals for aub-categories as illustrated in Table 8 on the following page. The breakdown of vacant land will be analyzed in a following aection titled Vacant Land summary. Approximately 32,832 acres of the Town's 33,408 acres are devoted to the land uses in Table 8. The Planner's Database includes every parcel of land in Foster, but does not include roads and road right"s of way. The remaining 555 acres are comprised of road right of ways (ROWr), and open water bodies that form property boundaries.

The database was used to estimate the total length of roads in the Town. This figure is estimated to be around $102 \mathrm{miles.} \mathrm{The} \mathrm{number} \mathrm{was}$ calculated by totalling the frontage field in the Planner's Database and dividing it by 5,280 (feet/mile). This product is then divided by two to account for the two sides of a roadway. This is a rough estimate because frontages of all lots were scaled from reduced maps. 
Table 8.--Land Use Summary 1990 - Fogter, RI

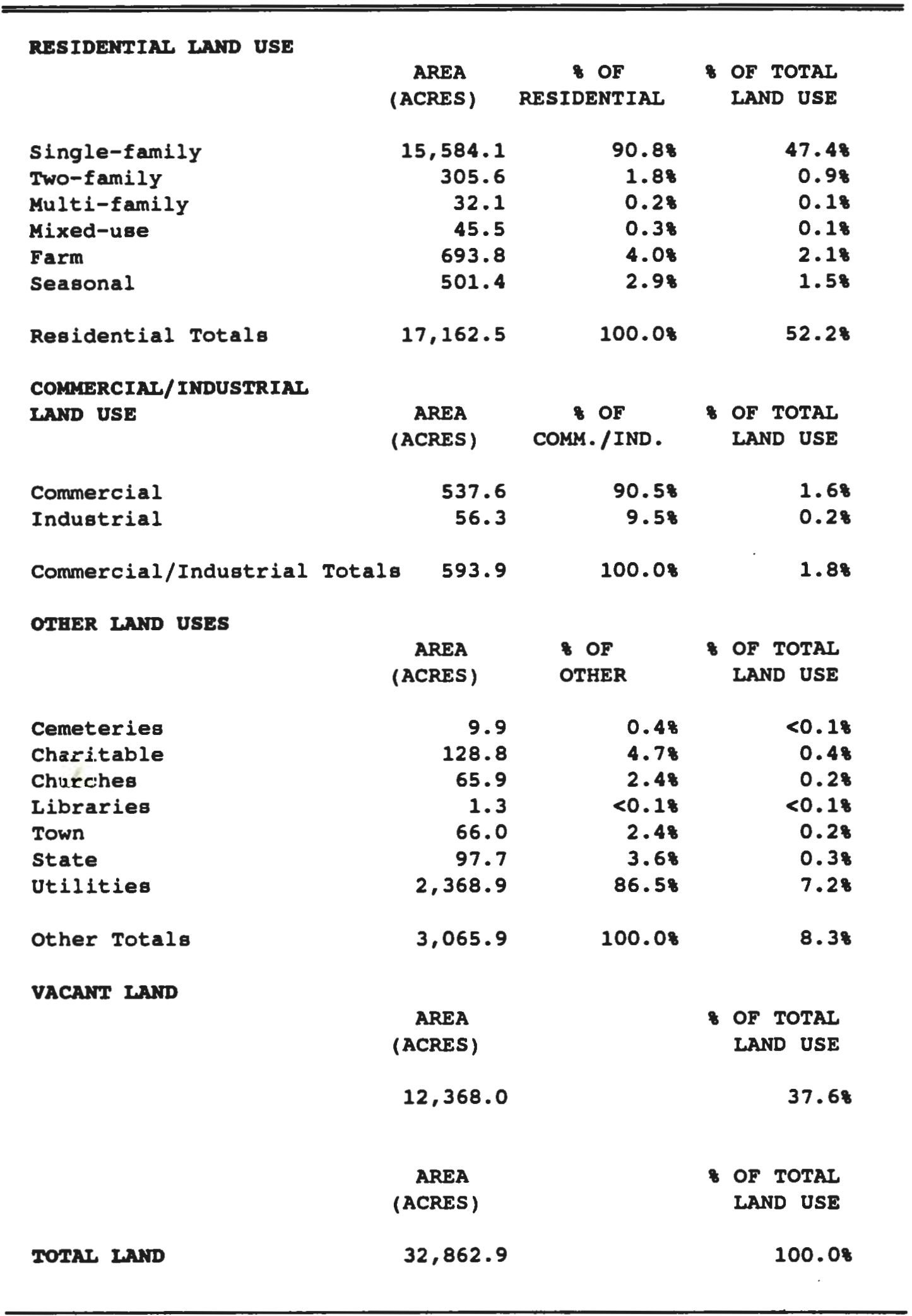


Vacant Land Summary

Knowing the location, size, property value and zoning of vacant parcels is of paramount importance to the planning process. Most development projects in rural areas target the vacant parcel. The Planner's Database provides the planner with a tool to help locate potential areas where growth may occur. Identification of these parcels is also important for conservation, preservation, fiscal, environmental and economic concerns.

The use codes for vacant parcels include categories for vacant residential, commercial, other, and open space. These values are very important to the performance of a Buildout Analysis. With the the planner can estimate the maximum number of units that can be constructed under current zoning regulations. This application of the Planner's Database was performed by the Project Team and is outlined in the scenarios section.

Table 9 contains the acreage of vacant residential and commercial land in Foster. The total for vacant residential is the number of acres that could potentially be developed for residential purposes.

Vacant land has been defined by the Project Team as areas that are currently taxed as such. When one views a map or aerial photo of Foster, our calculated percentages for vacant land may appear low. There is a considerable amount of open land that is connected to parcels of land dedicated to other uses, such as a single family-residence on 45 acres. These areas are, however, accounted for by the Project Team's Buildout Analysis and considered potential areas of expansion within Town. 
Table 9.--Vacant Land 1990 - Foster, RI

\begin{tabular}{lrc}
\hline \hline & $\begin{array}{c}\text { AREA } \\
\text { (ACRES) }\end{array}$ & $\begin{array}{c}\text { OF } \\
\text { VACANT }\end{array}$ \\
Residential & $12,293.4$ & 99.08 \\
Commercial & 74.6 & 1.08 \\
Total & $12,368.0$ & \\
\hline
\end{tabular}

In addition to the 327.4 acres of land owned in Foster by Narragansett Electric, the company possesses 75.6 acres of easements across properties. This land was also not included in the vacant land totals because the Project Team felt that even though the land is vacant according to strict interpretation, it is set aside for utility use. The number of acres in easements were also not included because they are only legal manifestations that would lead to a double counting. Table 10 lists the easements that are owned by the Narragansett Electric Company in Foster.

The major portion of utility owned land in Foster is owned by the Providence Water Supply Board. The agency owns 2041.5 acres in the Scituate Reservoir Watershed. Although this land is technically vacant it is serving a definite assigned purpose. This land is being withheld from development to preserve the quality of the reservoir. Table 11 indicates the parcels that are owned by the Providence Water Supply Board. 
Table 10.--Narragansett Electric Company Easements

Foster, RI

\begin{tabular}{rrr}
\hline \hline MAP & LOT & $\begin{array}{c}\text { AREA } \\
\text { (ACRES) }\end{array}$ \\
& & \\
3 & $20 B E$ & 31.9 \\
6 & $15 \mathrm{BE}$ & 1.0 \\
6 & $25 \mathrm{AE}$ & 0.7 \\
6 & $27 \mathrm{AE}$ & 0.7 \\
6 & $29 \mathrm{AE}$ & 7.4 \\
9 & $33 \mathrm{AE}$ & 24.9 \\
12 & $13 \mathrm{AE}$ & 0.1 \\
19 & $31 E$ & 0.6 \\
22 & $38 \mathrm{BE}$ & 5.5 \\
22 & $38 \mathrm{CE}$ & 2.8 \\
& & \\
TOTAL & & 75.6 \\
& &
\end{tabular}

Table 11.--Parcels Owned by Providence Water Supply Board Foster, RI

\begin{tabular}{rrr}
\hline \hline MAP & LOT & $\begin{array}{c}\text { AREA } \\
\text { (ACRES) }\end{array}$ \\
& & \\
3 & 11 A & 25.6 \\
6 & 16 & 25.0 \\
6 & $21 A$ & 13.0 \\
6 & 26 & 33.0 \\
9 & 27 & 196.0 \\
9 & 35 & 984.0 \\
12 & 12 & 24.0 \\
12 & 39 & 80.0 \\
12 & 47 & 144.0 \\
12 & 62 & 11.0 \\
12 & 66 & 482.0 \\
21 & 11 & 23.9 \\
& & 2041.5 \\
TOTAL & & \\
& & \\
\hline
\end{tabular}

The property values of vacant parcels are important to consider in the planning process. There is a need to evaluate the impacts changing the tax rate of a lot or when a parcel needs to be purchased for a public need such as land for a new school. The Planner's Database contains information on vacant parcels including map and lot, property value, acreage and use code. Sorts can be executed for the criteria of vacant parcels the Town may desire to purchase.

The Planner's Database contains fields indicating the presence of wetlands and location within the Scituate Reservoir watershed. This information could be quickly provided to the Planning Board as part of a staff report regarding proposals for vacant lots on its agenda. 
Basic Housing Characteristics

Housing characteristics such as square footage, number of bedrooms and number of bathrooms can be indicators of confidence in the economy of a region or the nation. One would also expect that changes in household size and composition would be reflected in housing characteristics. For example, it would be logical to assume that the trend for the formation of smaller households (3.07 persons per household in 1970 down to 2.7 in 1980 from the RI state Guide Plan Element 121, Land Uвe 2010) would result in a reduction in overall building area and the number of

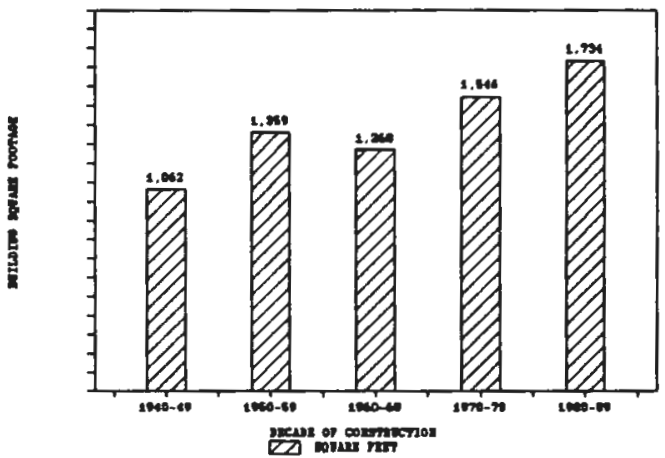

Figure 7.-Average Bullding Area by Decade - Foster, RI bedrooms.

The data collected on Foster and data collected nation wide refute this notion. As Figure 7 indicates building size has been increasing since the 608. The increasing house size in Foster is part of an ongoing trend toward the construction of luxury housing.

The increased share for high-end homes for trade-up buyers is due to, among other things demographic trends (an aging population), and income trends (a greater inequality in the distribution of income) (Crist 1989, 11).

In the decade starting in 1970 the median square footage of a single family home in Foster was 1,640, in the 808 the median increased to 1,730. A nation wide study which sampled over 1 million new singlefamily homes, revealed that the median house size in the 708 was approximately 1,655 square feet and had increased slightly to 1,660 in 
808. The average house size for these same time periods in Foster was 1,577 in the $708,1,640$ in the 808 . The nation wide averages were, higher than Foster' $8,1,755$ (708) and 1,834 (808). The difference in house size between Foster and the rest of the Nation could be attributed to the tendency to build smaller homes in the Northeast because of the relatively high cost of heating fuels and the colder climate. Table 12.--Housing Characteristics by Grade - Foster, RI

\begin{tabular}{|c|c|c|c|c|}
\hline Grade & $---6+$ & $4+5$ & 3 & $1+2$ \\
\hline Square Feet & 1,738 & 1,283 & 1,110 & 803 \\
\hline Total Rooms & 1.8 & 7.0 & 5.6 & 4.2 \\
\hline Bedrooms & 3.3 & 3.2 & 2.7 & 1.8 \\
\hline Bathrooms & 2.4 & 1.9 & 1.4 & 0.9 \\
\hline Building Value & $\$ 182,962$ & $\$ 111,306$ & $\$ 70,837$ & $\$ 30,081$ \\
\hline Property Value & $\$ 77,475$ & $\$ 59,668$ & $\$ 49,095$ & $\$ 36,895$ \\
\hline
\end{tabular}

Although overall house size has been steadily increasing, the nation wide trend for the construction of increasing numbers of "highend luxury" homes is not evident in Foster. Table 12 only about 28 of the homes in Foster were given a Building Grade of 6 or higher. Homes with a Building Grade of 6 or greater are considered to be superior to the typical mass produced homes in that they are constructed with the very best materials and workmanship and often with some special purpose features. Twenty-eight percent of the homes had above average Building Grades, 4 and 5. These homes were typically constructed prior to 1945 and have good plaster finishes and extensive trim in living spaces. Homes rated as grade 3, or average, are the standard contemporary homes, are commonly mass-produced and may be partially or entirely prefabricated. Average homes will typically use standard windows, doors, 
plumbing and heating systems. Below average grades, 1 and 2 , are characterized as being constructed of inexpensive, light-weight materials. Grade 2 homes will have inexpensive doors, windows, and may have mechanical and plumbing system which may be considered inadequate by today's standards. A grade 1 home may lack some or all of the facilities necessary for year-round occupation.

As Table 12 indicates, Building Grade is indicative of more than just workmanship. This table shows the average square footage, total rooms, bedrooms, bathrooms, building value and property value for each grade grouping. With the exception of the average number of bedrooms per grade grouping, there appears to be a substantial difference in the building characteristics from one grade grouping to the

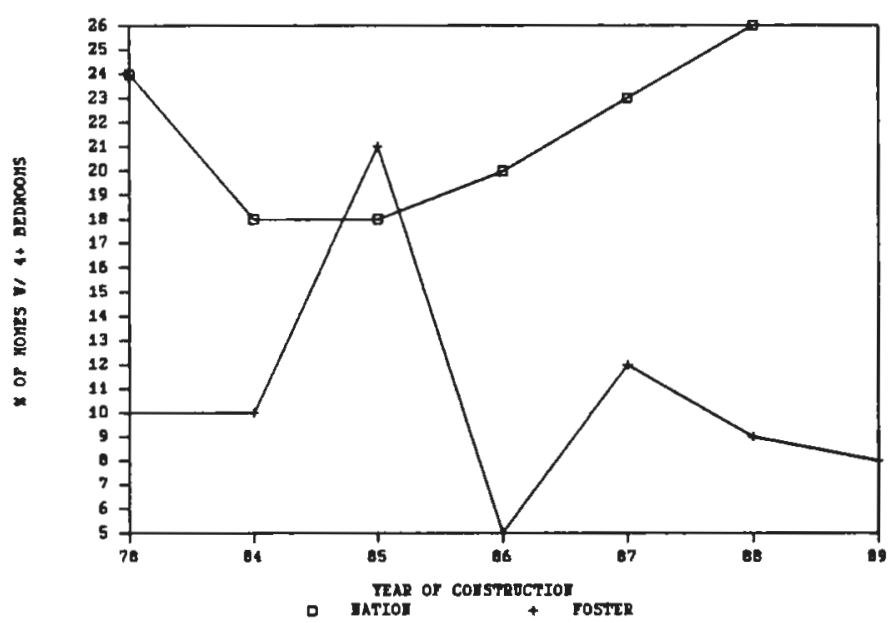

next.

Figure 8.--Housing Units with Four or More Bedrooms - U.S. and Foster, RI

While overall

house size in Foster has followed the National trend, the number of single family homes with four bedrooms or more, has not. Figure 8 illustrates this trend. Nation-wide, there was a dip in the mid-eighties (248 down to 188), and a steady climb, peaking in 1988, with 268 of homes having four or more bedrooms. The percent of homes in Foster with four or more bedrooms ran well below that of the Nation, with the 
exception of 1985 which was 3 percentage points higher than the National figure for that year, at 218. Apparently, the increase in overall house size should be attributed to an increase in room size, or to an increase in the number of rooms, other than bedrooms.

The national trend for an increasing number homes with more than two bathrooms is in evidence in Foster. Figure 9

shows the percentage of homes with more than two bathrooms in the Nation, and in Foster. Once

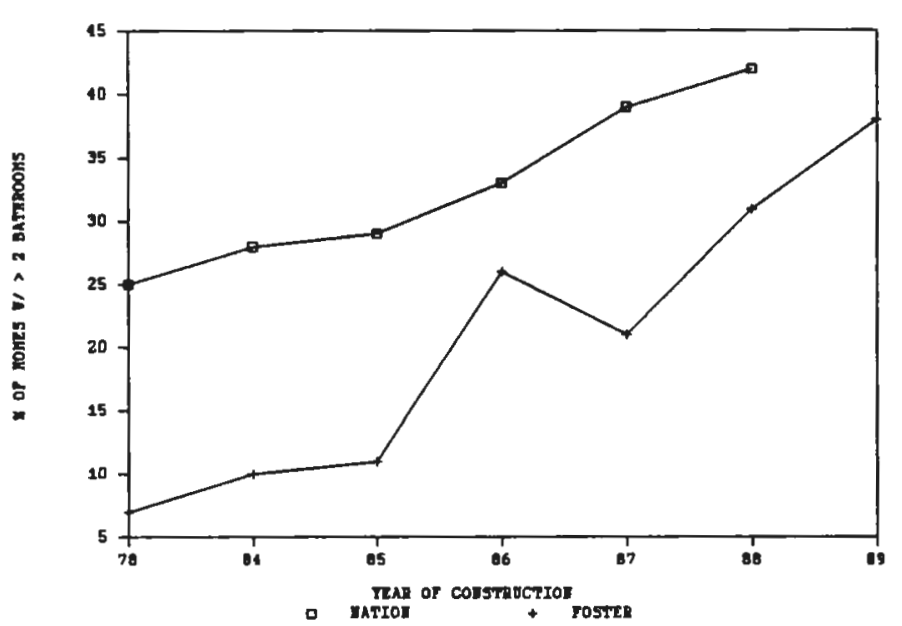
again, the percentages Figure 9.--Homes With More Than Two Bathrooms are lower throughout the U.S. and Foster, RI range but they are increasing at a rate similar to that of the nation. Part of the increase in house size mentioned above could be attributed to the increase in the number of bathrooms in Foster homes. Energy Use

It has been almost 15 years since the "energy crisis". Little attention has been paid to home heating methods. The focus has been on improving insulation and system efficiency. The Project Team felt this was valuable data to collect. Analysis of the occurrence of heating systems in residential units, could provide the planner with information on households affected by problems in the provision of fuel, especially in winter. For instance, the December 1989 heating fuel shortage's 
impact on the Town, although in most instances not life threatening, could be evaluated.

The data field HEAT TYPE that

is included in the Planner's

Database enables the Planner the

opportunity to assess current

methods of heating systems employed

in residential and commercial units.

Oil is the predominant source of

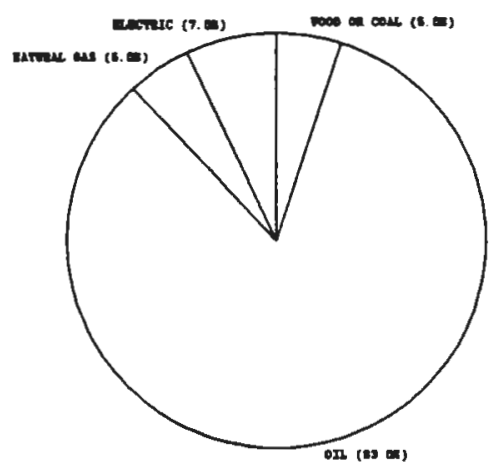

heating in residential dwellings in Figure 10.--Heating Type Percentages Foster, RI

Town, 838 of all units. The remaining units use wood and coal, natural

gas or electric heat in nearly equal proportions. Not represented in the data are two residences in Town that use solar power as their primary heating source. The percentages of residences using the four major heating types are shown in Figure 10.

The Project Team compiled.totals for residential units in Foster. Table 13 shows various heating types and the level of use. While the raw totals represent the start of baseline data, they need to be evaluated carefully to determine trends within Foster.

A clear picture of what is happening to energy system placement in homes in Foster must be viewed over time. To identify the trend in the installation of home energy systems, dwellings were grouped into the decades they were constructed. The percentage change for each energy type between decades was calculated and plotted. This calculation indicates the difference over the previous decade of the percentage of new homes that installed each respective heating type. 
Decade groupinga for the analyois were 1940-1950, 1950$1960,1960-1970$, and 1970-1980. The groupings represent all residential units built in that decade. For example, grouping 1950-1960 represents houses constructed that have
Table 13.--Residential Heating Types Foster, RI

\begin{tabular}{lr}
\hline HEATING TYPE & \multicolumn{1}{c}{ OF } \\
& RESIDENCES \\
WOOD OR COAL & 71 \\
OIL & 1150 \\
NATURAL GAS & 72 \\
ELECTRIC & 84 \\
TOTAL & 1377 \\
\hline
\end{tabular}

YEAR_BUILT dates in the Planner's Database ranging from 1950-1959. 1940 was chosen as the benchmark year because these homes are still most likely using the heating systems that were originally installed. Homes built prior to 1940 have a greater chance that there heating system has been upgraded. This analysis is general and does not take into account homes built after 1940 that may have changed heating systems. Table 14 displays the actual totals for heating systems by decade.

Table 14.--Heating Types for New Units by Decade - Foster, RI

\begin{tabular}{lrrrrr}
\hline \hline & \multicolumn{7}{c}{ DECADE } \\
HEATING TYPE & 1940 & 1950 & 1960 & 1970 & 1980 \\
& & & & & \\
WOOD OR COAL & 12 & 5 & 5 & 10 & 9 \\
OIL & 82 & 115 & 119 & 222 & 201 \\
NATURAL GAS & 7 & 6 & 5 & 4 & 24 \\
ELECTRIC & 3 & 2 & 10 & 28 & 35 \\
& & & & & \\
\hline
\end{tabular}

The graph indicates that natural gas is becoming the heating type of choice in the 1990s. Coal, wood and oil are holding fairly steady. The use of electricity as a primary heating source peaked around 1960 and has been dropping ever since. Figure 11 shows the trend in the 
choice of energy sources for new residential units since 1940.

The trend in

choice of energy source

in Town is comparable to

what is happening in the

United States as a

whole. The use of gas

for the primary heating

source is rising, use of

electricity as a primary

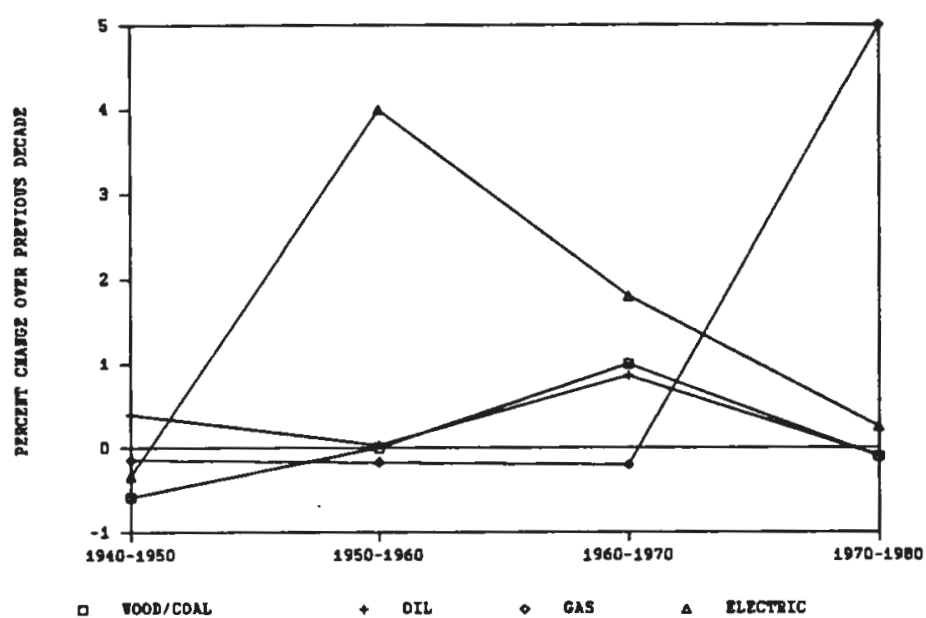

heating source is

Figure 11.--Change in Installed Heating Systems

dropping and other

by Decade - Foster, RI

heating types are remaining stable (Crist 1989).

Mentioned earlier, but not represented in the data is the fact that two homes in Foster have solar energy as their primary source of. heating. The homes were built in the $1970 \mathrm{~s}$ and the 1980s. Alternative heating sources could become more prominent in Town as the technology becomes more cost effective and as other sources become prohibitively expensive.

\section{Forecasting Uses}

Population Estimate

The small town planner is usually faced with very limited resources to perform a population census at the local level. Reliance on the Decennial United States Census for population data often leaves the Town speculating about its population during the years between 
enumerations. The Planner's Database can be used to estimate Foster's population on a yearly basis.

The Project Team developed a population estimation model that takes into consideration the total number of bedrooms, past population trends, and the average number of persons per bedroom. The total number of bedrooms in town can easily be determined using the Planner's Database. U.S. Census population data can be used to determine the average number of persons per bedroom. By totalling the number of bedrooms in Foster and multiplying it by the Town's factor for persons per bedroom a reasonably accurate population estimate can be made. Crucial to the accuracy of these projections is the periodic updating of the Planner"s Database.

Figure 12 shows the three projection trends used by the Project Team. The total number of bedrooms in town since 1940 was derived from the Planner's Database by totalling the number of bedrooms by year of construction. The graph shows the population and total number of bedrooms increasing slowly through 1950, and then increasing at a higher rate through the $1980 \mathrm{~s}$. The number of persons per bedroom increased in the 408 and 508, paaking in the early 19608. This increasing trend indicates the effeit of the pust-war "baby boom" and a relatively constant number of badrooms per house. Since the $1960 \mathrm{~s}$ the number of persons per bedroom has been decreasing at a linear rate. This trend is indicative of two phenomena; smaller family size, and the increasing trend of the number of bedrooms per house. It may also be an indication of an increasing number of so-called "empty-nesters"; parents whose children have moved, resulting in a lower number of persons per bedroom. 


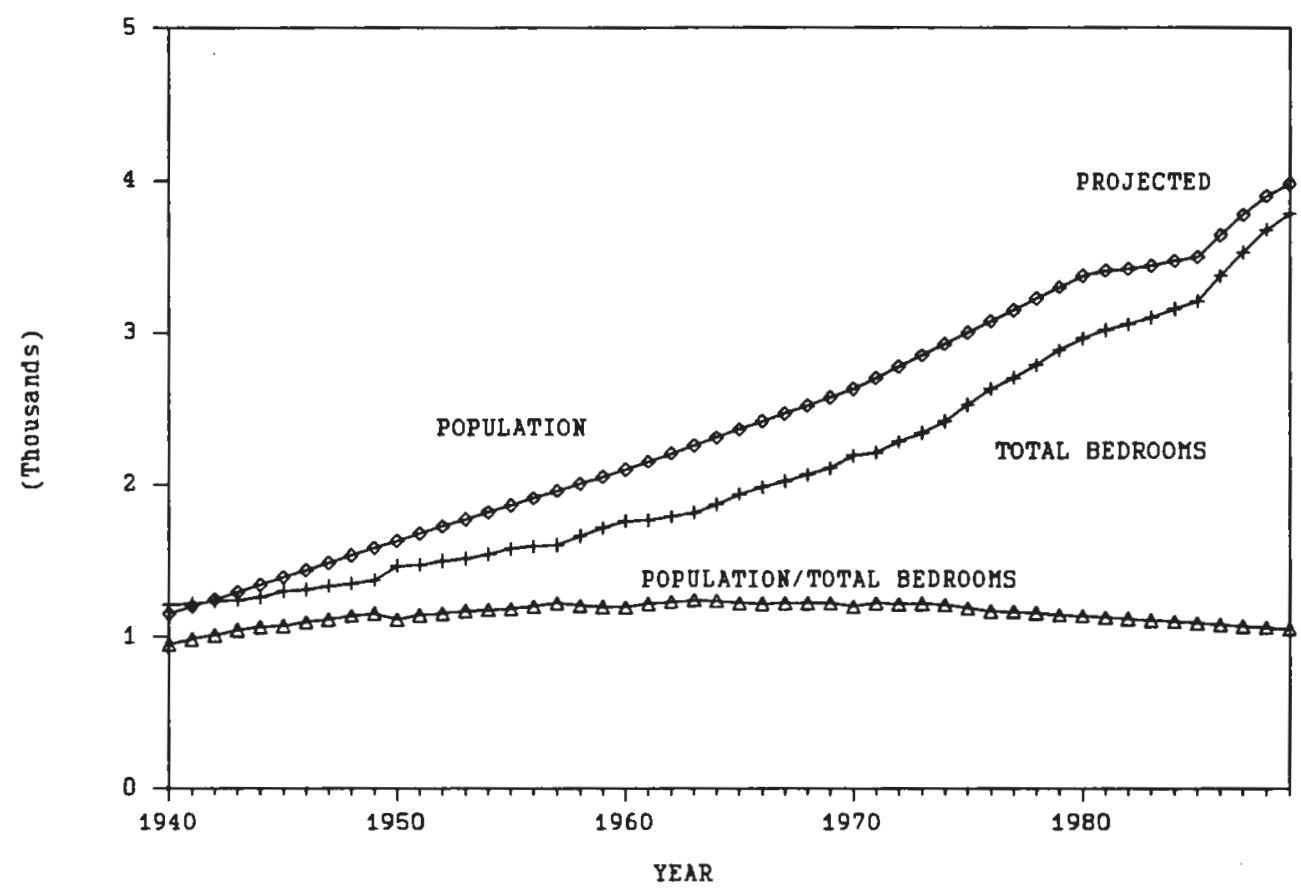

Figure 12.--Population Estimate by Number of Persons per Bedroom Foster, RI

The Project Team projected the decreasing linear trend of persons per bedroom from 1970 to 1980 up to the present. An estimate of the current population can be derived by multiplying the projected number of persons per bedroom by the known number of bedrooms in town. Figure 12 shows the Project Team's 1990 population estimate for Foster to be around 4,000 persons.

This procedure can be used for population projections by combining a buildout analysis' prediction of the future number of bedrooms with the projected number of persons per bedroom. 
Frontage Buildout

The buildout analysis is a method of determining how much development is feasible in a given area based on different zoning scenarios and combinations of environmental constraints. Every town has a carrying capacity for development. Theoretically that capacity is reached when every buildable parcel of land is subdivided so that it satisfies the minimum zoning requirements and is then built on. It is possible for towns, such as Foster, with large lot zoning to reach this theoretical capacity. Though possible, it is not likely because of the agrarian nature of the Town. Some buildable land can be expected to remain in farm use or just as open space for its visual quality. The underlying theory of this analysis is that in the competition between land uses the one with the highest bid rent will, over time replace the one with the lower bid rent (Alonzo 1960). Therefore, unless a new crop is developed that grows well in rocky, acidic soil and brings a higher return per acre than that of land used for residences, farm land will continue to be converted for regidential use.

Through the use of historical building records (the number of certificates of occupancy issued for residences per year) it is possible to estimate when a town will reach its buildout capacity. For instance, if it is determined that buildout will be reached with the addition of 3,000 housing units and an average of $150 \mathrm{co}$ 's were issued per year in the last decade we can estimate that it will take approximately 20 years to reach buildout. Changes in zoning which allow for greater density, new technology which might allow septic systems to be built in previously prohibited areas and down turns or, upswings in the housing 
market will ultimately effect the final buildout numbers as well as the time it takes to reach capacity.

The ability to predict the amount of development that can occur in a town is vital for a Town that is attempting the long-range planning of services. Reliable information regarding the development potential of the town is essential for the various departments to plan for increases in service demand. The great expense associated with capital improvements make it necessary for towns to start budgeting for them well in advance of the actual need. Knowing the eventual population of the Town based on the build-out analysis will allow Foster to avoid making costly incremental decisions regarding capital improvements. The fields from the database used to complete this initial buildout analysis include: Map, Lot, Parcel Area, and Frontage. The frontage of each lot was determined from the Town's plat maps. Only those parcels with frontage on Town approved roads were considered. Parcels designated residential, mixed use, vacant, farm, open space, and other improved were considered for this residential buildout analysis. Parcels designated as residential and farm were considered to have at least one structure occupying 4.6 acres of the parcel's total acreage and 300 feet of its frontage. These parcels will need to have a minimum frontage of six hundred feet and at least 9.2 acres to be considered in the buildout. Vacant parcels, on the other hand, will be considered for the buildout if they meet the minimum zoning requirements - minimum of 300 feet frontage and a parcel size of at least 4.6 acres. 
of the 2,256 parcels in the database 532 parcels met these minimum criteria. Calculation fields were added to the database in order to determine the total number of buildable lota. In order to determine the maximum number of lotg that could potentially be subdivided from a particular parcel, it was first necessary to determine whether the limiting constraint on the parcel was lot frontage or lot size. The road frontage of each parcel was divided by 300 (minimum frontage) and the acreage of the parcel was divided by 4.6 (minimum acreage) the quotients of these calculations were compared. The smaller of the two represents the limiting constraint to subdivision. The total number of frontage lots which satisfy minimum zoning requirements was determined by summing the smaller of the limiting constraint quotients.

An additional calculation was necessary for the non-vacant parcels because a etructure already occupies part of the larger parcel. One lot with 4.6 acres and 300 feet of frontage must be subtracted from the total for each residential parcel.

From the 532 parcels with excess frontage and acreage 1,224 smaller lots were derived. In most cases it was the frontage parameter that dictated how many subdivision lots could be derived from a parcel. Table 15 indicates the total number of potential frontage lota available for development by Map and also indicates the percentages of parcels and Maps which are developable. This figure represents the total number of lots that can be legally cut, given the Towns existing zoning, and road configuration. The actual number of buildable frontage lots will undoubtedly be smaller due to the placement of existing houses, odd shaped lots and environmental constraints. 
Table 15.--Frontage Buildout Worksheet and Totals

\begin{tabular}{|c|c|c|c|c|c|}
\hline \multirow[b]{2}{*}{ MAP } & \multirow{2}{*}{$\begin{array}{c}\text { \# OF } \\
\text { PARCELS }\end{array}$} & \multicolumn{2}{|c|}{ BUILDABLE } & \multirow{2}{*}{$\begin{array}{l}\& \text { OF } \\
\text { PARCEL }\end{array}$} & \multirow{2}{*}{$\begin{array}{l}\text { OF } \\
\text { TOTAL }\end{array}$} \\
\hline & & LOTS & ACRES & & \\
\hline 1 & 36 & 78 & 390 & 368 & 198 \\
\hline 2 & 29 & 44 & 220 & 318 & 128 \\
\hline 3 & 29 & 71 & 355 & 398 & 198 \\
\hline 4 & 25 & 76 & 380 & 318 & 198 \\
\hline 5 & 31 & 76 & 380 & 318 & 208 \\
\hline 6 & 28 & 65 & 325 & 338 & 228 \\
\hline 7 & 33 & 75 & 375 & 318 & 198 \\
\hline 8 & 25 & 80 & 400 & 478 & 298 \\
\hline 9 & 13 & 31 & 155 & 358 & 78 \\
\hline 10 & 31 & 68 & 340 & $35 \%$ & 198 \\
\hline 11 & 42 & 101 & 505 & 568 & 308 \\
\hline 12 & 22 & 51 & 255 & 338 & 138 \\
\hline 13 & 32 & 91 & 455 & 348 & 258 \\
\hline 14 & 29 & 52 & 260 & 428 & 168 \\
\hline 15 & 23 & 53 & 265 & 348 & 228 \\
\hline 16 & 31 & 52 & 260 & 238 & 138 \\
\hline 17 & 23 & 47 & 235 & 338 & 148 \\
\hline 18 & 32 & 82 & 410 & 418 & 258 \\
\hline 19 & 6 & 10 & 50 & 548 & 258 \\
\hline 20 & 6 & 12 & 60 & 478 & 218 \\
\hline 21 & 3 & 6 & 30 & 978 & 168 \\
\hline 22 & 3 & 3 & 15 & 528 & 78 \\
\hline TOTALS & 532 & 1224 & 6120 & 368 & 198 \\
\hline
\end{tabular}

Backlot Buildout

There are many large lots in Foster that have development

potential, but lack the necessary frontage on a Town road. Large lots

with enough frontage to accommodate a subdivision road must be accounted for in order to accurately assess the development potential in Town. For this part of the buildout analysis the Project Team made the assumption that all parcels exceeding 25 acres, after frontage lots have been subtracted, have potential for development with the construction of a road.

For this part of the buildout the database was sorted and all lots with less than 25 acres were eliminated. This sort yielded 205 parcels 
which were considered for further backlot subdivision. A sampling of these lots was conducted to determine the extent to which environmental constraints would inhibit development. A constraints map developed by Everett Associates for the Town of Foster was used in conjunction with the Plat Maps. Wetlands, large areas of poor soll, bedrock outcrops, and steep slopes were all considered in this sample. Forty eight lots (208 of 205) were examined. It was found that approximately half of the acreage associated with these backlots was unsuitable for development. A 508 discounting of all parcel acreage was done based on the sample.

All parcels were examined on the plat maps to determine whether lot configuration or location of wetlands on a lot might further constrain residential development. Certain parcels meet the acreage requirement, but are configured in such a way that it would be impossible to subdivide them into lots that the Town is likely to approve. In addition, parcels which had wetlands or large water bodies forming barriers between the frontage and the back acreage, were further discounted.

A more accurate assessment of the environmental constraints to development can be conducted using the Planner's Database. As the Planner's Database becomes more sophisticated due to the availability of more detailed lot-specific soil and wetland data, a more accurate assessment of environmental constraints to development can be conducted. From the 205 parcels with acreage in excess of 25 acres approximately 1,067 lots could be subdivided. Table 16 shows the number of back lots available for development by Map and also indicates the percentage of parcels and Maps which are developable. Many of the lots 
Table 16.--Backlot Buildout Worksheet and Totals

\begin{tabular}{|c|c|c|c|c|c|}
\hline \multirow[b]{2}{*}{ MAP } & \multirow[b]{2}{*}{ PARCELS } & \multicolumn{2}{|c|}{ BUILDABLE } & \multirow{2}{*}{$\begin{array}{l}\text { OF } \\
\text { PARCEL }\end{array}$} & \multirow{2}{*}{$\begin{array}{l}8 \text { OF } \\
\text { TOTAL }\end{array}$} \\
\hline & & LOTS & ACRES & & \\
\hline 1 & 13 & 54 & 270 & 418 & 138 \\
\hline 2 & 18 & 68 & 340 & 418 & 198 \\
\hline 3 & 13 & 37 & 185 & 318 & 108 \\
\hline 4 & 12 & 72 & 360 & 438 & 188 \\
\hline 5 & 17 & 116 & 580 & 508 & 318 \\
\hline 6 & 7 & 48 & 240 & 368 & 168 \\
\hline 7 & 14 & 67 & 335 & 398 & 178 \\
\hline 8 & 9 & 55 & 275 & 668 & 208 \\
\hline 9 & 8 & 49 & 245 & 508 & 118 \\
\hline 10 & 12 & 63 & 315 & 468 & 188 \\
\hline 11 & 7 & 20 & 100 & 448 & 68 \\
\hline 12 & 13 & 57 & 285 & 428 & 148 \\
\hline 13 & 10 & 61 & 305 & 378 & 178 \\
\hline 14 & 8 & 24 & 120 & 358 & 78 \\
\hline 15 & 5 & 24 & 120 & 238 & 108 \\
\hline 16 & 18 & 108 & 540 & 398 & 278 \\
\hline 17 & 7 & 52 & 260 & 458 & 168 \\
\hline 18 & 13 & 57 & 285 & 368 & 178 \\
\hline 19 & 0 & 0 & 0 & 08 & 08 \\
\hline 20 & 1 & 4 & 20 & 248 & 78 \\
\hline 21 & 0 & 0 & 0 & 08 & 08 \\
\hline 22 & 0 & 0 & 0 & 08 & 08 \\
\hline TOTALS & 205 & 1036 & 5180 & 418 & 168 \\
\hline
\end{tabular}

in this total are clustered in groups of two or three. Constructing roads to access lots in groups of two or three may prove unprofitable for most developers depending on how flexible the Town is with regard to enforcement of its road standard. Based on the number of new Town roads that have been built to accommodate back lot subdivisions it is likely that many of these lots will remain undeveloped. However, as frontage lots become scarce, the cost of raw land may increase to a point where developers find that the development of back lots will bring a favorable return, even with the construction of costly roads.

In order to estimate when the Town will reach buildout, it will be necessary to determine how many lots might be developed in future years 
based on historical building trends. An average of 28 units a year have been built in Foster since 1980. Because this average reflects the slumping economy of the early eighties and the boom of middle eighties it should cover the spectrum of possible development scenarios. Frontage lot buildout, 1,224 lots, will be reached in approximately 44 years, or by the year 2034 if, 28 lots are developed each year. Total buildout, 2,291 lots, could be reached in 81 years at the present rate. Frontage Buildout Population Estimate

Table 17 shows Foster's possible future population in five year increments, based on the buildout estimates and R.I. Division of Planning's persons per household projection. The projected population at frontage buildout in the year 2034, will be 6,748 . The projected population at final buildout in the year 2071 could reach 9,311.

Table 17.--Population Estimate Based Upon Frontage Lot Buildout

\begin{tabular}{lllll}
\hline Year & $\begin{array}{l}\text { Persons/ } \\
\text { Household }\end{array}$ & $\begin{array}{l}\text { New } \\
\text { Units }\end{array}$ & $\begin{array}{l}\text { Pop. } \\
\text { Increase }\end{array}$ & $\begin{array}{l}\text { Total } \\
\text { Pop. }\end{array}$ \\
1990 & 2.48 & 140 & 347 & 3996 \\
1995 & 2.43 & 140 & 340 & 4343 \\
2000 & 2.38 & 140 & 333 & 5683 \\
2005 & 2.32 & 140 & 324 & $5340 \quad 4901^{1}$ \\
2010 & 2.32 & 140 & 324 & 5664 \\
2015 & 2.32 & 140 & 324 & 5988 \\
2020 & 2.32 & 140 & 324 & 6312 \\
2025 & 2.32 & 140 & 324 & 6636 \\
2030 & 2.32 & 140 & 324 & 6960 \\
2035 & & &
\end{tabular}


dropping since before 1960. While the eventual number of units at buildout may stay the same, the population occupying those units will not remain static. In 1960, Rhode Island's household size was 3.20 and there were 31 units per 100 people, in 1980 household gize was 2.70 and there were 37 housing units per 100 people. If the trend of decreasing household size continues, as expected there will be 2.32 people per household and 43 housing units per 100 people. Demand for housing will be greater because of the greater number of units needed per 100 people as a result of smaller household size. Ultimately the time it takes to reach buildout could be shortened by this increased demand.

Another factor, which would tend to increase the time to buildout is the tendency for there to be a declining rate of growth at the upper level of the buildout capacity. The shortage of buildable lots in Town may force people to look elsewhere for housing there by reducing the number of lots which will be developed in a year. Additionally, land which is left undeveloped in the upper reaches of the buildout period will be the least desirable land which probably had been previously overlooked because other development opportunities existed.

Fiscal Implications of Buildout

As the population of the Town increases the demand for services will also increase, as will the expense of providing these services. Increased revenues generated by new residents in the form of property taxes, do not usually keep pace with the increased expense of providing schools, libraries, fire, police, road maintenance and recreation for new residents. Federal assistance cut-backs and state mandated tax restrictions have further hindered the municipalities ability to raise 
needed revenue. Having a clear picture of the possible future demand on services will enable the Town to investigate mechanisms which could lessen the disparity between service demand and available revenues. The buildout analysis used in conjunction with the Planners Data Base can provide the Town with glimpse of the type of service demand increase to expect in the coming years and can give an indication of the Town's ability to meet those demands given the current tax structure. To estimate the revenue generated by new development we would first look at the number of new homes that would be added to the tax roll by a given year. The number of new units multiplied by the median assessed valuation of homes in the town, times the tax rate $(\$ 30 / 1000$ at 508 valuation) would total the amount of revenue generated from new homes.

The Town can also expect an increase in revenue from the taxation of tangible items and motor vehicles. For every dollar of revenue generated in real property taxes about $\$ .20$ in additional revenue from the taxation of these other taxable items, will be gained.

Assuming the 1,224 frontage lots identified in the initial buildout are in fact cut and have single family homes built on them, approximately 1.5 million dollars in additional property taxes and $\$ 300,000$ in taxes from tangibles and motor vehicles would be generated in a year.

Funds to support the educational system typically comprise the largest part of a Towns budget. The number of students attending public schools has a direct relationship to the school budget. Table 18 shows that by applying a student per housing unit multiplier to the figures 
generated in the buildout a fairly accurate estimate of the school population can be made.

Two bedroom, three and four bedroom units have multipliers of $0.246,1.131$, and 2.068 respectively. Of the 313 single family homes built in Foster since 1980, approximately 268 have had two bedrooma, 608 have three bedrooms, and 8 have had four bedrooms. These same percentages will be used in estimating how many bedrooms will be found in the 1,224 units to be built on frontage lots.

Table 18.--Predicted Number of Additional School-Age Children (Based Upon Frontage Buildout)

\begin{tabular}{|c|c|c|c|}
\hline of Lots & $\begin{array}{l}\text { of } \\
\text { Units }\end{array}$ & * Multiplier & $\begin{aligned}= & \text { school age } \\
& \text { Children }\end{aligned}$ \\
\hline $2882 \mathrm{BR}$ & 343 & 0.246 & $=84$ \\
\hline $6383 \mathrm{BR}$ & 771 & 1.131 & $=872$ \\
\hline $984 \mathrm{BR}$ & 110 & 2.068 & $=228$ \\
\hline 1008 & 1224 & & $=1184$ \\
\hline 1 source: & Burchell 1985 & & \\
\hline
\end{tabular}

The Town will have to plan on accommodating close to 600 additional students in its elementary school. Currently the cost of supporting a student in the Foster school system is $\$ 3,241$. At current funding levels the Town will have to raise $\$ 1.9$ million dollars to support the additional students. However, it is unlikely that the current system would be adequate to support 600 additional students. Additional classrooms and staff would be necessary so funding levels would have to be increased.

The $\$ 1.8$ millon dollars in additional revenue generated by new residents will clearly not cover the cost of providing basic services. 
This is one example of a fiscal impact generated by residential growth, there are a whole host of other impacts both direct and indirect which the Town must plan for. Through the manipulation of data in the Planner's Database these impacts can be identified.

Scenario Building

Analyzing the Effects of Proposed Legislation

The Planner's Database can be used to quickly estimate the effects of zoning changes or proposed overlay districts, such as the one proposed in the Draft Scituate Reservoir Management Plan (1989). The Table 19.--Vacant Commercial and Industrial Land in the scituate Reservoir prohibition of all new watershed

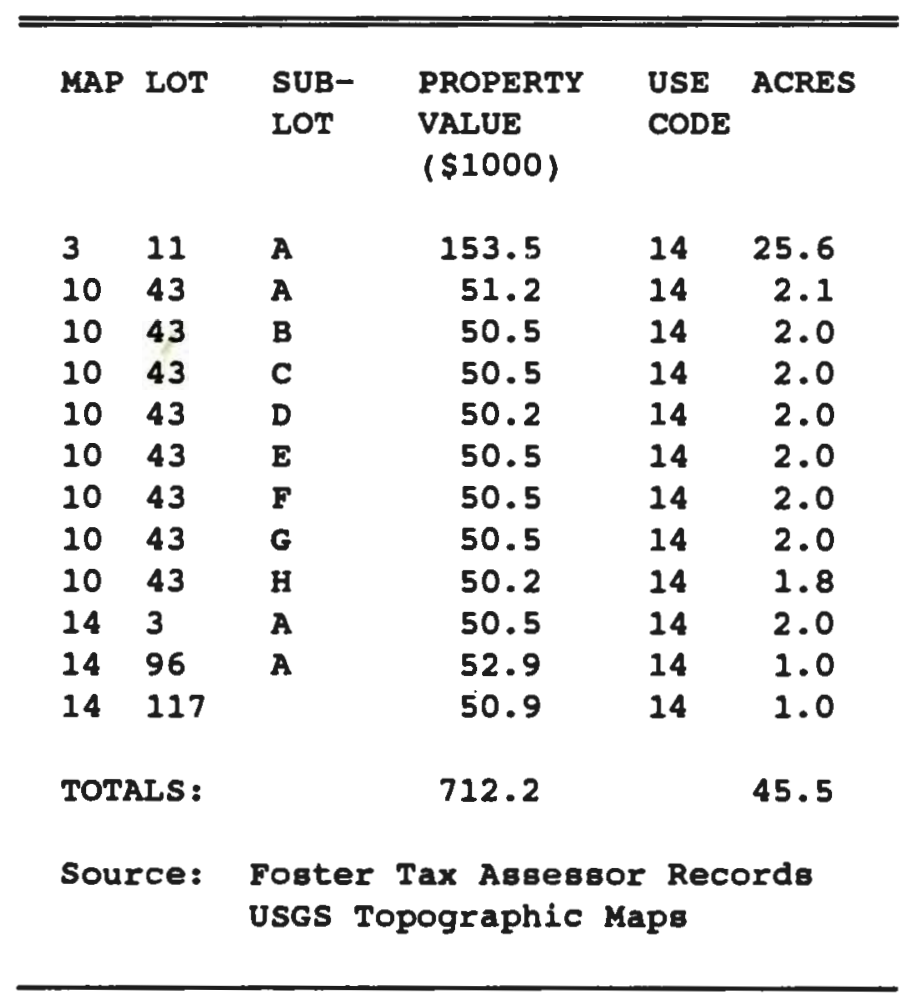

commercial and industrial

uges in the scituate

Reservoir Watershed. The

database can be used to

derive a quick approximation

that estimates the effect

this proposed legislation

might have on the town's tax

base.

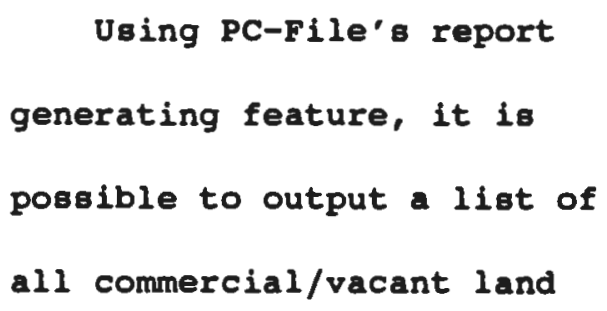

that is within the scituate Reservoir watershed. The report includes the parcel size and land value as shown in Table 19. There are twelve vacant 
parcels of land in the scituate Reservoir Natershed that are currently classified as commercial or industrial vacant land. The total area of the twelve parcels is 45.5 acres. The total assessed value of these parcels is over $\$ 712,000$.

Assuming all new commercial and industrial uses are prohibited, the only other use left is residential. Vacant commercial and industrial land is assessed at a higher value than corresponding residential land. The assessed value of commercial and industrial land in the scituate Watershed would fall accordingly.

We can estimate the difference in arsegsed value (and therefor tax revenues) by comparing the average assessed value of vacant commercial/ industrial land and the average assessed value of vacant residential land. Table 20 shows the average values per acre as determined by the Project Team using the Planner's Database.

Table 20.--Vacant Land Value in the Scituate Reservoir Watershed

\begin{tabular}{lcc} 
& $\begin{array}{c}\text { Vacant Commercial/ } \\
\text { Industrial Land }\end{array}$ & $\begin{array}{c}\text { Vacant Residential } \\
\text { Land }\end{array}$ \\
$\begin{array}{l}\text { Property Value } \\
\text { Acres }\end{array}$ & 412,200 & $\$ 25,101,000$ \\
Average Value/Acre & $\$ 15,652$ & 10,564 \\
Source: Foster Tax Assessor & $\$ 2,376$ \\
\hline
\end{tabular}

The 45.5 total acres of vacant commercial/industrial land in the Scituate Reservoir Watershed has a current property value of $\$ 712,200$. If this same land was assessed as vacant residential land it would have 
a property value of only $\$ 108,108$ (45.5 acres $\bullet 2,376$ dollars/acre vacant residential land) a $\$ 604,000$ decrease. At the current tax rate of approximately $\$ 30$ per thousand at $50 \%$ valuation, the town would stand to lose nearly $\$ 18,000$ per year in tax revenue.

Another source of tax revenue loss can be found in the Waterghed Management Plan's recommendation that would require the disallowing of all substandard lots of record. A substandard lot of record is a parcel which does not meet the minimum lot standards of current zoning regulations, but is considered buildable since the creation of the lot predates the zoning regulation. There are currently sixty-eight substandard lots of record totaling 117 acres in the scituate Reservoir Watershed. These substandard lots have a current taxable value of over 1.25 million dollars.

Substandard lots of record in the watershed were identifled by using PC-File's report generating capability. Records were selected for output based upon the following criteria; the acreage data field is less than 4.6, the use code field was equal to 13 , and the watershed field code was equal to 1 . In this fashion, only lots that are smaller than the minimum building size (less than 4.6 acres), that are currently residential vacant land (use code 13), and are within the scituate Reservoix Watershed (watershed code equals 1) were selected. The substandard lots of record actually have a higher average per acre value than standard residential vacant land. This can be explained by the fact that every lot is taxed higher for the first buildable lot and at a lower rate for excess land. By definition, substandard lots of record have no excess land so each small parcel is rated quite high. 
Table 21.--The Average Value of Substandard Lots of Record vs. Unbuildable Iand in the Scituate Reservoir Waterghed

\begin{tabular}{|c|c|c|}
\hline & $\begin{array}{c}\text { Substandard Lota } \\
\text { of Record }\end{array}$ & $\begin{array}{l}\text { Unbuildable } \\
\text { Land }\end{array}$ \\
\hline Property Value & $\$ 1,256,000$ & $\$ 175,500$ \\
\hline Acres & 117 & 117 \\
\hline Average Value/Acre & $\$ 10,752$ & $\$ 1,500$ \\
\hline Foster Tax & Asgessor & \\
\hline
\end{tabular}

Table 21 shows the resulting loss of value when substandard lots of record are taxed as non-buildable lots. The 1088 of over one million dollars of market value results in an additional tax revenue logs of over $\$ 15,000$ per year.

These are just two of the possible sources of tax revenue loss to the town that might be attributed to the implementation of the scituate Reservoir Management Plan. While the Project Team does not necessarily believe that the Regervoir Management Plan is either good or bad, it lo important to be aware of the potential side effects of proposed legislation. The Planner's Database provides one quick and easy way to evaluate the effects of such plans. Identification of Land for Acquisition

The planner is often faced with the task of identifying potential sites for acquigition. The Planner's Database permits easy identification of parcels meeting specific selection criteria. The criteria identifying land for acquisition for Town purposes such as recreation, schools and conservation, can come from many different sources. After compiling the information the planner can query the 
database for the specific conditions. Concerns of effect on tax base, environment, zoning and location can all be addressed.

The following simple example is a hypothetical application of the Planner's Database in identifying land for acquisition. The Town is looking for a parcel of land for a new school and recreational complex. The requirements for the site are:

- Between 35 and 55 acres in size
- Road frontage greater than 1500 feet
- Some wetlands present on site
- Land that is presently vacant

The planning objective is to locate a parcel for a school/recreational complex that is of adequate size to accommodate baseball and soccer fields, a school building and associated parking, and the potential construction of a natural educational trail system.

The question that is asked of the database is - How many vacant parcels in town are between 35 and 55 acres, potentially have wetlands and have a road frontage greater than 1500 feet? Using the pc-File report function this can be accomplished. By performing a complex search that satisfies the above requirements a report can be generated listing the lots. The search would be (ACREs $>=" 35^{n}$ \& ACRES $<=" 55^{n}$ ) \& (USE_CODE\# = "13"| USE_CODE\# = $15^{n} \mid$ USE_CODE\# $\left.=" 33^{n}\right) \&$ (WETLANDS = "1") \& (FRONTAGE $>=" 1500$ ). The use codes indicate parcels that are presently vacant.

When setting up the report format, information regarding the property value and current zoning of each parcel meeting the criteria can be printed. Generating a "short-list" makes the selection process easier. The final decision would have to be made evaluating each of the 
parcels spatially on the town maps and by field inspection. Table 22

presents the results of this hypothetical search.

Table 22.--Vacant Land Purchase Scenario

\begin{tabular}{|c|c|c|c|c|c|c|c|}
\hline MAP & LOT & $\begin{array}{l}\text { PROP } \\
\text { VALUE }\end{array}$ & ACRES & $\begin{array}{l}\text { USE } \\
\text { CODE }\end{array}$ & ZONE & $\begin{array}{l}\text { ROAD } \\
\text { FRONT. }\end{array}$ & WETLAND \\
\hline 3 & 3 & 75.3 & 47.5 & 13 & 1 & 2256 & 1 \\
\hline 3 & 58 & 66.4 & 37.7 & 13 & 1 & 3159 & 1 \\
\hline 4 & 68 & 68.0 & 36.5 & 13 & 1 & 1584 & 1 \\
\hline 8 & 49 & 51.1 & 36.0 & 15 & 1 & 2000 & 1 \\
\hline 11 & 89 & 73.0 & 50.0 & 13 & 1 & 2900 & 1 \\
\hline
\end{tabular}

Five parcels satisfied the site selection criteria. This is the baseline data for the decision. Evaluation of each site's location, property value, zoning and frontage would lead to a final decision. This listing is only an example, additional reports with varying requirements could also be generated to weigh other alternatives.

Archiving Summary statistics

Periodically saving the database to a disk as a permanent record of the Town's current land-use condition will provide the planner an opportunity to perform detailed trend analyses. The permanent record will act as an archive of the Town's present condition.

Each of the land use codes can be segregated by plat map to summarize the type, amount and location of the various land uses in Town. By gaving the database periodically, it will be possible to identify trends and potential problems. The following tables provide an example of just a few of the categories that can be analyzed in this fashion. For this example the different land-uses were categorized for each map by area, frontage and number of parcels. 
The flexibility of the Planner's Database will allow the planner the option of analyzing any of the collected data fields over time. As different needs and situations arise, specific data summaries could be generated using the archived disk.

This breakdown of information provides the planner with information regarding the number of each type of residential unit by map. Table 23 shows the results of the sort for USE_CODE 1, indicating total acreage, frontage and number of parcels by map and Town totals. This information is useful if the planner needs to determine the distribution of single family housing units in Town. The number of parcels in a map could be plotted on a full size representation of Foster that indicates map boundaries. Average road frontage of ingle family residences in map 9 could be calculated. This would be accomplished by dividing frontage $(19,904)$ by the number of parcels (45) which yields an average frontage of approximately 442 feet. Following Table 23 are tables that describe the same conditions and details for each specific use code in Town. This illustrates the high level of detail available with the Planner's Database. 
Table 23.--Single-Family Residences by Map Foster, RI

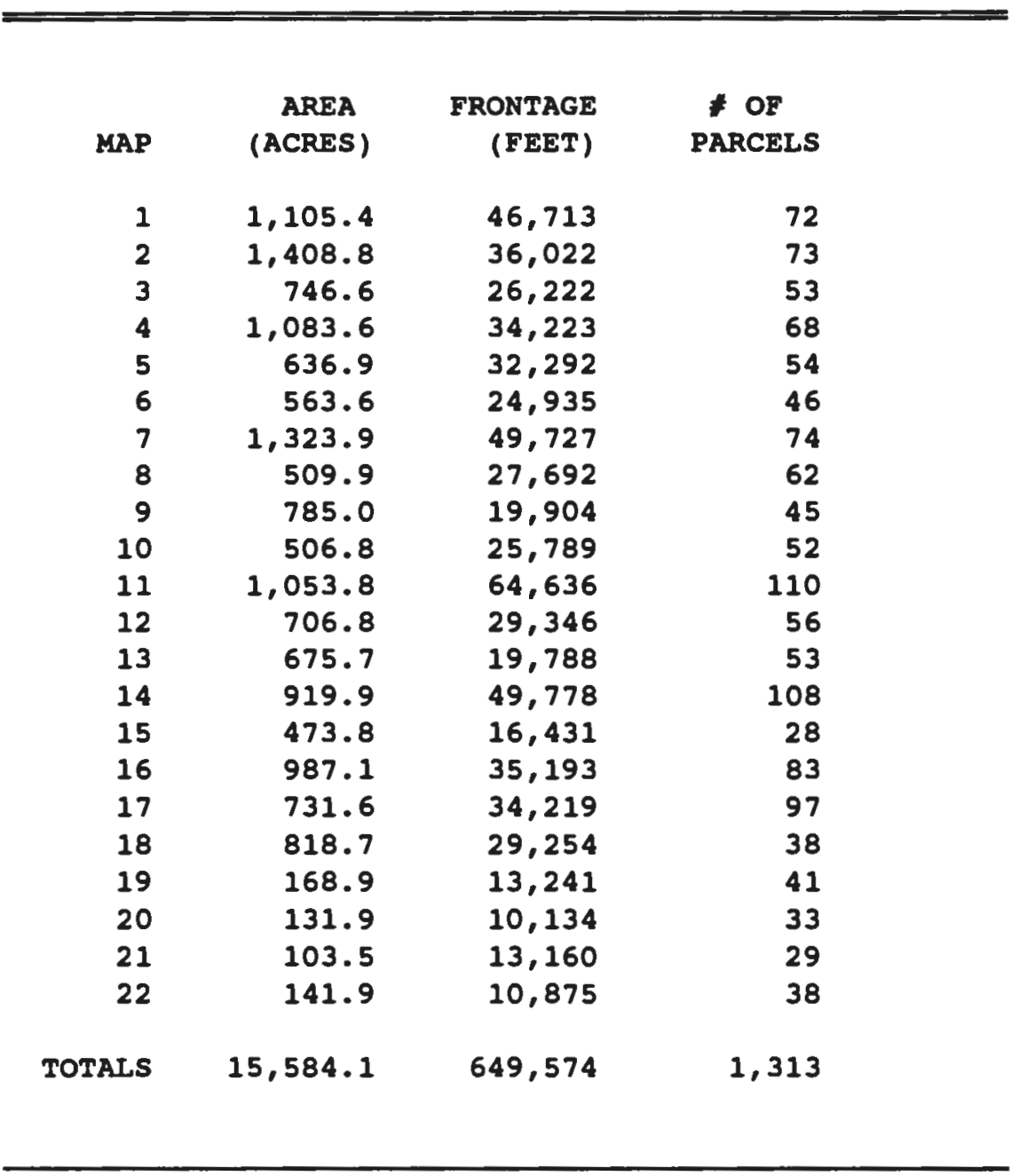


Table 24.--Two-Family Units by Map - Foster, RI

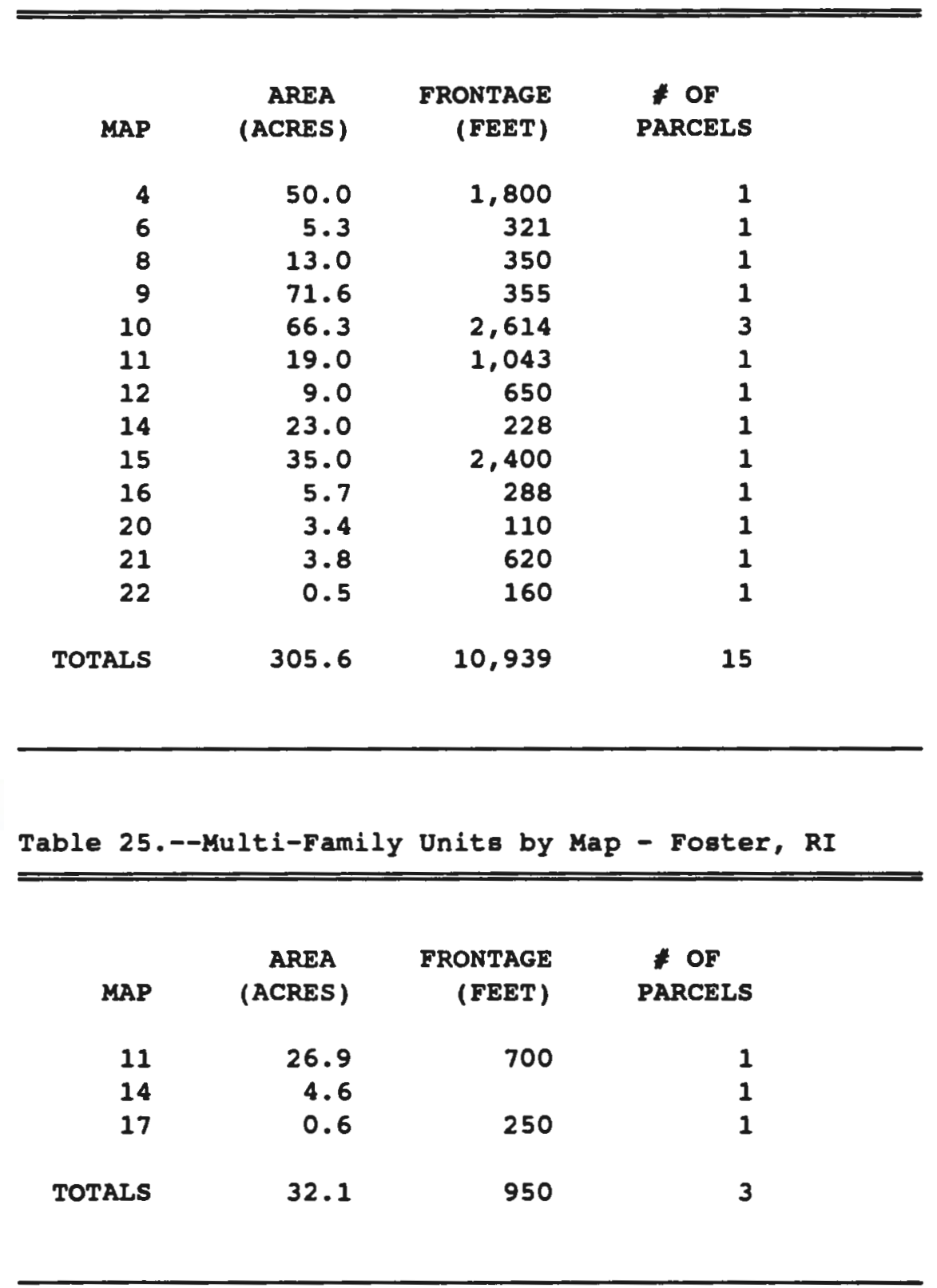


Table 26.--Mixed Residential Units - Foster, RI

\begin{tabular}{rrrr}
\hline \hline MAP & $\begin{array}{r}\text { AREA } \\
\text { (ACRES) }\end{array}$ & $\begin{array}{r}\text { FRONTAGE } \\
\text { (FEET) }\end{array}$ & $\begin{array}{c}\text { OF } \\
\text { PARCELS }\end{array}$ \\
3 & 3.9 & 400 & 1 \\
13 & 23.1 & 1,330 & 1 \\
14 & 7.5 & 988 & 2 \\
15 & 10.0 & 220 & 1 \\
20 & 0.2 & 540 & 1 \\
22 & 0.8 & 300 & 1 \\
TOTALS & 45.5 & 3,778 & 7 \\
& & & \\
\hline
\end{tabular}

Table 27.--Residential Farms by Map - Foster, RI

\begin{tabular}{rrrr}
\hline \hline MAP & $\begin{array}{r}\text { AREA } \\
\text { (ACRES) }\end{array}$ & $\begin{array}{r}\text { FRONTAGE } \\
\text { (FEET) }\end{array}$ & $\begin{array}{r}\text { OF } \\
\text { PARCELS }\end{array}$ \\
3 & 37.0 & 206 & 1 \\
4 & 162.0 & 3,692 & 4 \\
7 & 65.0 & 1,300 & 1 \\
8 & 142.8 & 4,400 & 1 \\
11 & 22.1 & 60 & 1 \\
14 & 119.9 & 948 & 2 \\
18 & 145.0 & 4,400 & 2 \\
TOTALS & 693.8 & 15,006 & 12 \\
& & & \\
\hline
\end{tabular}


Table 28.--Seasonal Residential Units - Foster, RI

\begin{tabular}{rrrr}
\hline & & & \\
MAPEA & $\begin{array}{r}\text { FRONTAGE } \\
\text { (ACRES) }\end{array}$ & $\begin{array}{r}\text { OF } \\
\text { (FEET) }\end{array}$ & \\
& & & \\
2 & 10.0 & 302 & 2 \\
4 & 120.0 & 3,150 & 3 \\
5 & 273.0 & 2,560 & 1 \\
6 & 22.8 & 2,160 & 1 \\
8 & 20.8 & 324 & 1 \\
13 & 51.7 & 2,079 & 10 \\
16 & 3.1 & 190 & 1 \\
\hline
\end{tabular}

Table 29.--Commercial Properties Less Than $\$ 100,000$ Foster, RI

\begin{tabular}{rrrr}
\hline & & \\
AREA & FRONTAGE & OF \\
(ACRES) & & & \\
(FEET) & 157 & 2 \\
10 & 2.2 & 1,550 & 2 \\
12 & 32.0 & 330 & 1 \\
13 & 6.1 & 578 & 2 \\
14 & 7.5 & 1,175 & 2 \\
17 & 33.3 & 1,270 & 10 \\
TOTALS & 3.4 & 5,060 & 2 \\
& 84.5 & & \\
\hline
\end{tabular}


Table 30.--Commercial Properties Greater Than $\$ 100,000$ Foster, RI

\begin{tabular}{rrrr}
\hline \hline MAP & $\begin{array}{r}\text { AREA } \\
\text { (ACRES) }\end{array}$ & $\begin{array}{r}\text { FRONTAGE } \\
\text { (FEET) }\end{array}$ & $\begin{array}{r}\text { OF } \\
\text { PARCELS }\end{array}$ \\
1 & 1.6 & 0 & 1 \\
4 & 60 & 4250 & 2 \\
5 & 81.6 & 2700 & 1 \\
8 & 14 & 1700 & 1 \\
10 & 108.2 & 9887 & 15 \\
11 & 34.1 & 530 & 3 \\
12 & 34.6 & 4255 & 2 \\
13 & 5.4 & 1147 & 2 \\
14 & 35.1 & 2453 & 4 \\
16 & 3.7 & 335 & 1 \\
17 & 46.6 & 1940 & 2 \\
18 & 12 & 480 & 1 \\
20 & 0.3 & 80 & 1 \\
21 & 15.9 & 300 & 3 \\
& & & \\
TOTALS & 453.1 & 30,057 & 39 \\
& & & \\
\hline
\end{tabular}

Table 31.--Total Industrial Properties - Foster, RI

\begin{tabular}{rrrr}
\hline & & & \\
MAP & $\begin{array}{r}\text { AREA } \\
\text { (ACRES) }\end{array}$ & $\begin{array}{r}\text { FRONTAGE } \\
\text { (FEET) }\end{array}$ & $\begin{array}{l}\text { \# OF } \\
\text { PARCELS }\end{array}$ \\
& & & \\
14 & 17.0 & 500 & 1 \\
17 & 39.3 & 3350 & 2 \\
TOTALS & 56.3 & 3,850 & 3 \\
\hline
\end{tabular}


Table 32.--Cemeteries by Map - Foster, RI

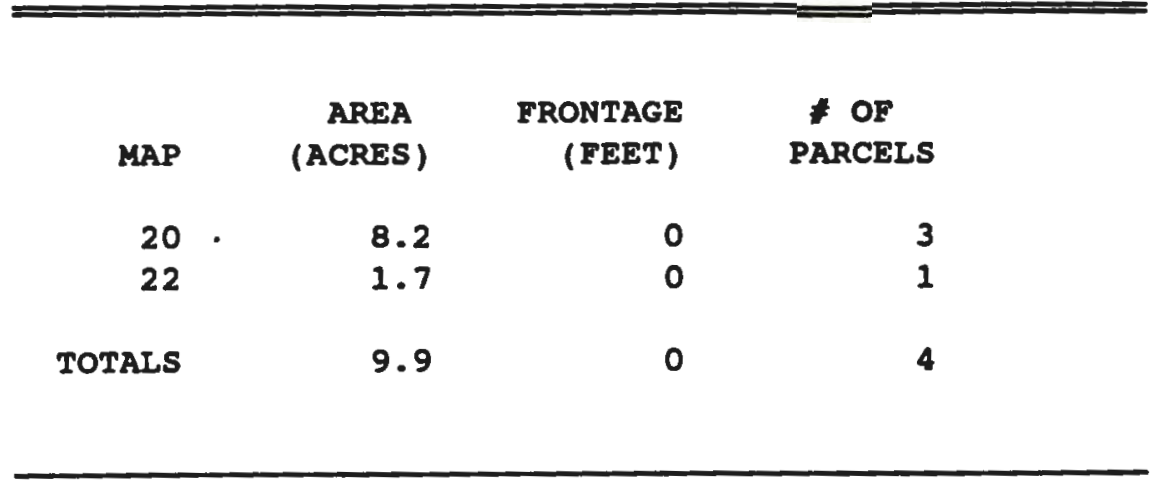

Table 33.--Charitable Property by Map - Foster, RI

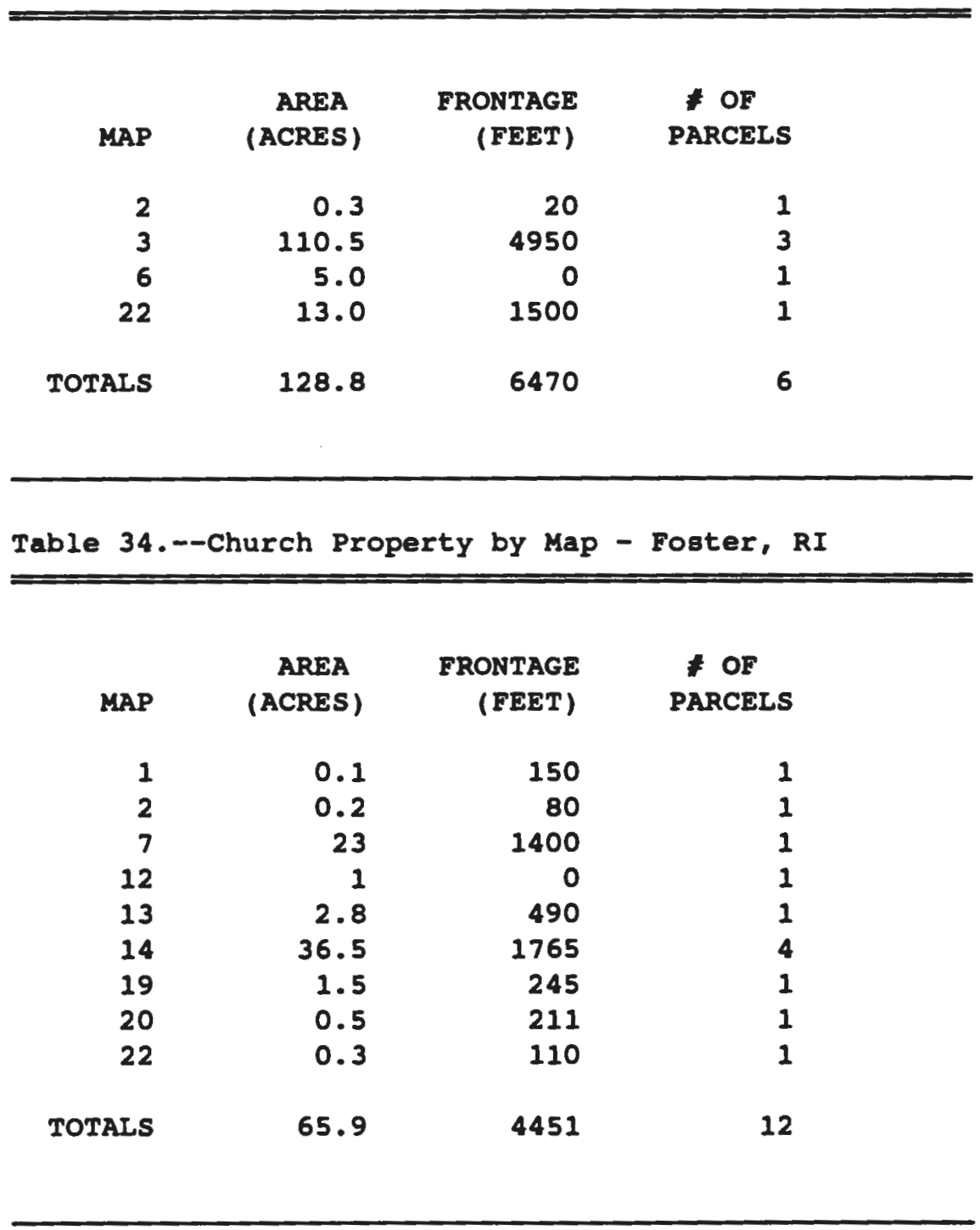


Table 35.--Library Property by Map - Foster, RI

\begin{tabular}{rrrr}
\hline & & \\
MAPEA & FRONTAGE & OF \\
(ACRES) & (FEET) & PARCELS \\
1 & 1.0 & 100 & 1 \\
20 & 0.3 & 160 & 2 \\
TOTALS & 1.3 & 260 & 1 \\
& & & \\
\hline
\end{tabular}

Table 36.--Town Property by Map - Foster, RI

\begin{tabular}{rrrr}
\hline & \multicolumn{1}{c}{ AREA } & FRONTAGE & OF \\
MAP & (ACRES) & PARCELS \\
& & & \\
1 & 8.3 & 640 & 2 \\
2 & 9.0 & 380 & 2 \\
6 & 20.0 & 0 & 1 \\
7 & 0.3 & 100 & 1 \\
12 & 0.1 & 86 & 1 \\
14 & 0.5 & 177 & 1 \\
18 & 8.0 & 0 & 4 \\
20 & 19.5 & 979 & 1 \\
22 & 0.3 & 40 & 14 \\
& & & \\
\hline
\end{tabular}


Table 37.--State Property by Map - Foster, RI

\begin{tabular}{rrrr}
\hline \hline & & & \\
MAP & $\begin{array}{r}\text { AREA } \\
\text { (ACRES) }\end{array}$ & $\begin{array}{r}\text { FRONTAGE } \\
\text { (FEET) }\end{array}$ & $\begin{array}{c}\text { OF } \\
\text { PARCELS }\end{array}$ \\
2 & 1.5 & 240 & 1 \\
4 & 5.0 & 390 & 1 \\
14 & 18.2 & 1262 & 1 \\
16 & 1.0 & 525 & 1 \\
17 & 66.0 & 2885 & 4 \\
19 & 6.0 & 320 & 1 \\
TOTALS & 97.7 & 5622 & 9 \\
& & & \\
\hline
\end{tabular}

Table 38.--Utility Property by Map - Foster, RI

\begin{tabular}{rrrr}
\hline \hline MAP & $\begin{array}{r}\text { AREA } \\
\text { (ACRES) }\end{array}$ & $\begin{array}{r}\text { FRONTAGE } \\
\text { (FEET) }\end{array}$ & $\begin{array}{r}\text { OF } \\
\text { PARCELS }\end{array}$ \\
3 & 68.1 & 777 & 4 \\
6 & 126.9 & 1583 & 7 \\
9 & 1185.7 & 6650 & 5 \\
12 & 742.1 & 11350 & 6 \\
15 & 106.3 & 2175 & 9 \\
17 & 68.5 & 0 & 7 \\
18 & 26.3 & 0 & 5 \\
19 & 12.2 & 488 & 1 \\
21 & 23.9 & 525 & 1 \\
22 & 8.9 & 520 & 3 \\
& & & 48 \\
TOTALS & $2,368.9$ & 24,068 & \\
\hline
\end{tabular}


Table 39.--Other Improved Land by Map - Foster, RI

\begin{tabular}{rrrr}
\hline \hline MAP & $\begin{array}{r}\text { AREA } \\
\text { (ACRES) }\end{array}$ & $\begin{array}{r}\text { FRONTAGE } \\
\text { (FEET) }\end{array}$ & $\begin{array}{r}\text { * OF } \\
\text { PARCELS }\end{array}$ \\
1 & 8.0 & 1030 & 2 \\
3 & 90.0 & 2780 & 1 \\
4 & 1.0 & 208 & 1 \\
5 & 52.4 & 1900 & 2 \\
6 & 95.0 & 3053 & 2 \\
8 & 72.3 & 2200 & 2 \\
10 & 115.0 & 1000 & 1 \\
11 & 6.4 & 1225 & 1 \\
12 & 76.0 & 2036 & 3 \\
15 & 7.1 & 1090 & 1 \\
16 & 6.4 & 731 & 1 \\
& & & 17.0 \\
TOTALS & 529.6 & $17,253.0$ & \\
\hline
\end{tabular}


Table 40.--Vacant Residential Land by Map - Foster, RI

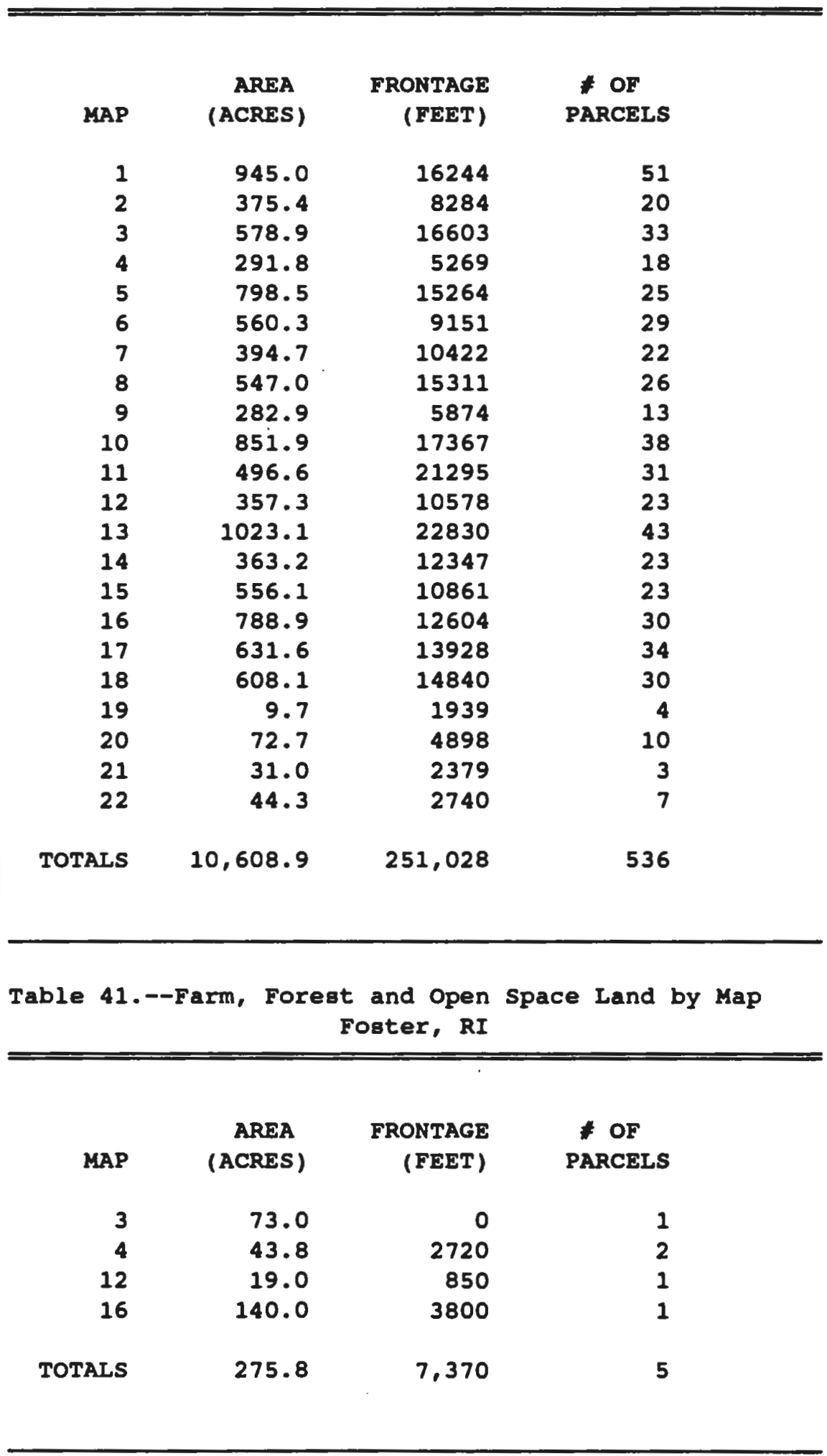


Table 42.--Vacant Commercial/Industrial Land by Map Foster, RI

\begin{tabular}{rrrr}
\hline \hline MAP & $\begin{array}{r}\text { AREA } \\
\text { (ACRES) }\end{array}$ & $\begin{array}{r}\text { FRONTAGE } \\
\text { (FEET) }\end{array}$ & $\begin{array}{c}\text { AF } \\
\text { PARCELS }\end{array}$ \\
1 & 25.6 & 537 & 1 \\
6 & 71.0 & 1200 & 3 \\
9 & 1180.0 & 6650 & 2 \\
10 & 70.6 & 4399 & 11 \\
12 & 741.0 & 11350 & 5 \\
14 & 4.0 & 869 & 3 \\
21 & 23.9 & 525 & 1 \\
& & & 26 \\
TOTALS & $2,116.1$ & 25,530 & \\
& & & \\
\hline
\end{tabular}

Table 43.--Other Vacant Land by Map - Foster, RI

\begin{tabular}{rrrr}
\hline \hline MAP & $\begin{array}{r}\text { AREA } \\
\text { (ACRES) }\end{array}$ & $\begin{array}{r}\text { FRONTAGE } \\
\text { (FEET) }\end{array}$ & $\begin{array}{r}\text { OF } \\
\text { PARCELS }\end{array}$ \\
2 & & & 1 \\
3 & 16.0 & 680 & 7 \\
4 & 134.9 & 420 & 4 \\
5 & 17.5 & 1800 & 1 \\
6 & 87.0 & 1500 & 9 \\
7 & 146.7 & 2726 & 8 \\
8 & 40.0 & 1605 & 2 \\
9 & 4.7 & 237 & 1 \\
10 & 69.5 & 0 & 8 \\
13 & 36.0 & 0 & 4 \\
14 & 82.2 & 1001 & 5 \\
15 & 32.4 & 215 & 3 \\
16 & 19.5 & 400 & 3 \\
17 & 9.0 & 0 & 1 \\
18 & 11.2 & 0 & 2 \\
20 & 46.0 & 515 & 2 \\
21 & 1.5 & 771 & 1 \\
22 & 3.0 & 475 & 63 \\
& & & \\
TOTALS & 879.1 & 14,745 & \\
& & & \\
& & & \\
\hline
\end{tabular}




\section{Additional Data Field:}

An advantage to using a magnetic database (softcopy) is that updating and changing is very easy. The Planner's Database has the ability to change as the Town does. The addition of new data fields and modifications to others can be made. The remainder of this section is devoted to new data fields that could be collected and entered. The Project Team identified several other fields that should be considered. Soil Type

The knowledge of the major soil types of a parcel is of great importance to the planning process. The Soil survey of Rhode Island is a good source of this type of information. The manual is published by the United States Department of Agriculture Soil Conservation Service. Soils are grouped, named and given a three letter code in the manual based on their physical characteristics and properties. The soil type code could be added to the Planner's Database.

Examples of the three digit code include SuB, ChB and WoB. SuB is in the sutton group, ChB is in the charlton group and Woodbridge soil. The manual contains information on all the soil groups suitability for septic systems, woodland use, agricultural uses, susceptibility to frost action and limitations to construction. 
This field is extremely valuable when assessing zoning and subdivision proposals. Consideration can be given to the physical properties of the soil and the construction that is proposed within it. similar to the wetlands field, the major soil type of a parcel can be used for general planning purposes and is not intended to replace on site scientific investigation.

Collection of the data for this field can be accomplished by overlaying the maps in the soil manual over the Town maps and coding each parcel. High intensity site specific soil information that exists for parcels or is required for subdivision approval could also be incorporated to improve the accuracy.

Steep slopes

The knowledge of where steep slopes are located in Foster is critically important to the land development process. When steep slopes are stripped of their vegetation the potential for erosion is increased. Soil erosion can have negative impacts on the quality of wetlands and drinking water.

Soil erosion can be mitigated through the use of preventative techniques including siltation fences, hay bales, grassed swales, and settling ponds during the construction phase. Recognizing parcels with steep slopes during the approval process insures that proper soil erosion prevention measures can be taken as well as the timely revegetation of disturbed slopes.

The information on steep slopes is available on a map that was produced by Everett Associates for the Town's 1982 Comprehensive Plan or the four United States Geological Survey (USGS) Quadrangles that cover 
Foster. The same method used to code the soil data could be employed. Aquifers

Since the Town relies on groundwater for its drinking water supply, protection of the aquifers is very important. Knowledge of a parcels location in relation to an aquifer is essential in evaluating development proposals. Certain uses within these areas should be regulated or prohibited. For example, nutrient loading calculations for individual sewage systems should be conducted when proposed over an aquifer to determine the impact on water quality.

Again the overlay approach can be engaged to determine which aquifer the parcels are located over. The source of the aquifer information would be the USGS Groundwater Maps that correspond to the quadrangle sheets that cover Foster.

Related to aquifer and groundwater protection, data flelds that indicate if underground storage tanks, like service stations have, injection wells or other potential contamination sources exist on the site could be entered. The Rhode Island Department of Environmental Management (DEM) and United States Environmental Protection Agency (EPA) are potential sources of this information.

Endangered species

The information for this potential data field is not distributed on a parcel specific basis. The reason for this is because many people want to have the "last one" of an endangered species. The Rhode Island DEM can provide information on the general areas where endangered species may be located. This field could be entered as either a yes or no. Yes (1) meaning that an endangered species exists in the area. This 
could be crose referenced with the information from DEM to determining the endangered species, and proper action can be taken.

General suggestions

The number of fields collected is only limited by the lmagination of the user of the Planner's Database and financial constraints. Other suggestions include number of children per household, types of business for commercial lots, distance from fire stations, agricultural uses and many others. As time goes on, so does the data required for the planning process, if the Planner's Database is properly maintained, it can stand the test of time.

\section{Compatibility with other systems}

Probably the most exciting and controversial planning tool available to the Planner as we enter the nineties is the advent of Geographical Information systems, or as it is commonly referee to, GIs. A GIS system is computer based technology that allows the planner to store, manipulate, and analyze large volumes of spatial data (Marble et al 1984). The spatial component of the Planner's Database ig achieved by crosg reference with Foster Town maps. A GIS combines these two elements.

The Rhode Island Environmental Data Center (EDC) is a cooperative effort between the Rhode Island DEM and the University of Rhode Island Department of Natural Resources sciences. The purpose of the project is to develop a statewide GIS. Data that is currently being entered for the State includes soila, hydrology, geology, roads and political boundaries (URI 1988). Collection of data for the additional fields 
Table 44.--Components of a GIS

1. A data input system which collects and/or processes epatial data derived from existing maps, aerial photos, etc.

2. A data storage and retrieval subsystem which organizes the epatial data in a form that permits it to be quickly retrieved by the user for subsequent analysis, as well as permitting rapid and accurate updates and corrections to be made to the spatial database.

3. A data manipulation system and analysis subsystem that performs a variety of tasks such as changing the form of the data through user defined aggregation rules or producing estimates of parameters and constraints for various space-time optimization or simulation models.

4. A data reporting subsystem which is capable of displaying all or part of the original database as well as manipulated data and the output from spatial models in tabular or map form. The creation of these map displays involves what is called digital or computer cartography. This is an area which represents a considerable conceptual extension of traditional cartographic approaches as well as a substantial change in the tools utilized in creating the cartographic displays.

Source: "Geographic Information Systems: An Overview" by Dr. Duane F. Marble

mentioned in the above section could potentially be generated by the EDC and incorporated into the Planner's Database.

Another advantage of the Planner's Database, and an incentive to keep the database updated, is the future compatibility with the Rhode Island GIS (RIGIS). When the Town is prepared to make a major investment into RIGIS compatible software and hardware, the Planner's Database will be able to provide a ready source of input data. PC-File has the ability to output into a RIGIS readable format. 


\section{Equipent Purchase}

As discussed in Chapter Two, the Planner's Database and PC-File are currently compatible with the Town's existing computer systems. However, in order for the planning staff to take full advantage of the database's capabilities it is recommended that the Town invest in a computer gystem for the Planning Department. The computer system selected should be compatible with existing Town systems as well as adaptable to future potential needs.

The Project Team recommends the purchase of an IBM compatible 80286 or 80386 microprocessor with a math co-processor. Elther of these systems will provide the speed and dependability necessary to run the PC-File based Planner's Database. It is also recommended that for future compatibility with GIS the Town invest in a high resolution color monitor such as the NEC 3D Multisync with a VGA graphics card.

\section{Conclusions}

The Planner's Database is just one tool to be used in preparing Foster for the twenty-first century. Planning for future growth is essential for preserving the rural character and high quality of life currently enjoyed by the residents of Foster.

The Planner's Database is cost effective and easy to operate. A new user will need to invest only a minimal amount of time learning the system. The database is easily updated and is forward compatible with new technologies and systems. By properly managing the database, the Town will be able to enjoy a planning asset with nominal investment in time and money. 
The applications demonstrated in this project are only an example of the many capabilities of the Planner's Database. Since there are no menu-driven formats, the user is not limited to pre-determined inflexible methods of analysis. Only future planning needs and situations will dictate how the database is utilized.

The Planner's Database is easily expanded with additional data fields. Some fields have been recommended by the Project Team for inclusion, others will be determined by the Town's future needs. In this way the database can continue to grow as a useful planning tool for the management of environmental, fiscal, and social needs. 
Alonso, William. 1983. A Theory of the Urban Land Market. Readings in Orban Analysis: Perspectives on Urban Form and structure, ed. Robert $\omega$. Lake. New Brunswick, NJ: Center for Urban Policy Research: 1-10.

Burchell, Robert W., Listokin, David. and William R. Dolphin. 1985. The New Practitioner's Guide to Fiscal Impact. New Brunswick, New Jersey: Center for Urban Policy Research.

Chapin, Stuart F., Jr. and E.J. Kaiser. 1985. Orban Land Ose Planning. Urbana: University of Illinois Press.

CPAD. 1989. The Hidden River. Kingston, RI: The University of Rhode Island Graduate Curriculum in Community Planning.

Everett, Michael. 1982. Foster, Rhode Island: Comprehensive Plan. Providence, RI: Everett Associates.

Kops, Daniel W., Hall, Lawrence Jr., Goetze, Rolf and Geraldo Canto. 1986. Managing Municipal Information Needs Osing Microcomputers. PAS Report No. 393. Chicago: American Planning Association.

Marble, Duane, F. 1984. Geographic Information Systems Overview. PECORA 9 Proceedings Spatial Information Technologies for Remote Sensing Today and Tomorrow. October 2-4, Sioux Falls, South Dakota: 1824.

Meyerson, Martin. 1956. Building the Middle-range Bridge for Comprehensive Planning. Journal of the American Institute of Planners. 22:2 (Spring): 58-64.

MMC Inc. 1989. Foster, RI, Fiscal Year 1989, Residential Manual. Chelmsford, MA.

Rhode Island Historical Preservation Commission. 1982. Foster, Rhode Island. Statewide Historical Preservation Report P-F-1. (June). Providence, RI: Rhode Island Historical Preservation Commission.

Smith, Kurth. 1990. Personal interview with the Town of Foster's plat map draftsman by the authors.

United States Department of Agriculture Soil Conservation Service. 1981. Soil Survey of Rhode Island.

University of Rhode Island. 1988. 1988-89 Bulletin of The Oniversity of Rhode Island Graduate School. Kingston, RI.

Winsor Associates. 1990. Housing Study for the City of Providence. Providence, RI. 
A P $P$ X D I $\mathbf{X}$

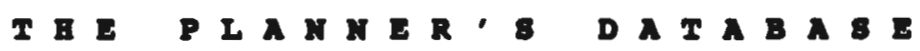




\begin{tabular}{|c|c|c|c|c|c|c|c|c|c|c|c|c|c|c|c|c|c|c|}
\hline Map & Lot & $\begin{array}{l}\text { Bldg. } \\
\text { Value }\end{array}$ & $\begin{array}{l}\text { Land } \\
\text { Value }\end{array}$ & Acres & $\begin{array}{l}\text { Land } \\
\text { Use }\end{array}$ & Zoning & $\begin{array}{l}\text { Bldg. } \\
\text { Grade }\end{array}$ & $\begin{array}{l}\text { \# of } \\
\text { Stories }\end{array}$ & $\begin{array}{l}\text { Occu- } \\
\text { pancy }\end{array}$ & $\begin{array}{l}\text { Heat } \\
\text { Type }\end{array}$ & $\begin{array}{l}\text { "of } \\
\text { Beds }\end{array}$ & $\begin{array}{l}\text { \# of } \\
\text { Baths }\end{array}$ & $\begin{array}{l}\text { Total } \\
\text { Rooms }\end{array}$ & $\begin{array}{l}\text { Year } \\
\text { Built }\end{array}$ & $\begin{array}{l}\text { 1st } \\
\text { Floor }\end{array}$ & Frontage & $\begin{array}{l}\text { Wet- } \\
\text { lands }\end{array}$ & $\begin{array}{l}\text { Water- } \\
\text { shed }\end{array}$ \\
\hline 1 & CEM & 0.0 & 0.0 & 0.0 & 70 & 1 & & 0.0 & & & & 0.0 & & & 0.0 & & & \\
\hline 1 & 1 & 0.0 & 9.5 & 3.1 & 13 & 1 & & 0.0 & & & & 0.0 & & & 0.0 & 350 & & \\
\hline 1 & $1 \mathbf{A}$ & 0.0 & 7.2 & 1.0 & 13 & 1 & & 0.0 & & & & 0.0 & & & 0.0 & & & \\
\hline 1 & $1 \mathrm{~B}$ & 0.0 & 7.8 & 1.4 & 13 & 1 & & 0.0 & & & & 0.0 & & & 0.0 & & & \\
\hline 1 & $1 \mathrm{C}$ & 0.0 & 8.2 & 2.1 & 13 & 1 & & 0.0 & & & & 0.0 & & & 0.0 & & & \\
\hline 1 & 2 & 0.0 & 47.4 & 6.9 & 13 & 1 & & 0.0 & & & & 0.0 & & & 0.0 & 600 & & \\
\hline 1 & $2 A$ & 38.9 & 0.0 & 0.0 & 5 & 1 & 2 & 0.0 & 1 & 2 & 0 & 0.0 & 0 & 1968 & 1.4 & & & \\
\hline 1 & $2 \mathrm{~A}$ & 67.9 & 53.4 & 5.5 & 1 & 1 & 3 & 2.0 & 1 & 2 & 4 & 2.0 & 8 & 1952 & 1.3 & 450 & 1 & \\
\hline 1 & 3 & 99.7 & 50.1 & 4.3 & 1 & 1 & 3 & 1.0 & 1 & 2 & 3 & 2.0 & 6 & 1967 & 1.4 & 3780 & 1 & \\
\hline 1 & 3 & 0.0 & 0.0 & 0.0 & 1 & 1 & 3 & 1.0 & 1 & 2 & 2 & 1.0 & 4 & 1966 & 0.7 & & & \\
\hline 1 & 4 & 96.0 & 53.4 & 8.0 & 1 & 1 & 3 & 1.5 & 1 & 2 & 4 & 2.0 & 8 & 1890 & 1.4 & 880 & 1 & \\
\hline 1 & 5 & 118.3 & 65.9 & 15.6 & 1 & 1 & 4 & 1.5 & 1 & 2 & 3 & 2.0 & 7 & 1720 & 1.4 & 1500 & 1 & \\
\hline 1 & 6 & 76.1 & 52.6 & 5.0 & 1 & 1 & 3 & 1.0 & 1 & 2 & 1 & 2.0 & 5 & 1960 & 1.3 & 400 & 1 & \\
\hline 1 & $6 A$ & 0.0 & 15.8 & 1.3 & 13 & 1 & & 0.0 & & & & 0.0 & & & 0.0 & & & \\
\hline 1 & 7 & 4.8 & 40.1 & 2.0 & 12 & 1 & & 0.0 & & & & 0.0 & & & 0.0 & 728 & & \\
\hline 1 & 8 & 52.8 & 56.9 & 8.6 & 1 & 1 & 3 & 2.0 & 1 & 2 & 3 & 1.0 & 6 & 1987 & 1.1 & 50 & 1 & \\
\hline 1 & $8 \mathbf{A}$ & 81.5 & 60.6 & 14.0 & 1 & 1 & 4 & 2.0 & 1 & 2 & 2 & 1.0 & 5 & 1985 & 0.8 & 600 & 1 & \\
\hline 1 & 9 & 132.9 & 54.9 & 6.6 & 1 & 1 & 4 & 2.0 & 1 & 2 & 3 & 2.0 & 7 & 1986 & 1.0 & 1124 & & \\
\hline 1 & 10 & 82.5 & 75.6 & 33.8 & 1 & 1 & 3 & 1.0 & 1 & 2 & 3 & 2.0 & 8 & 1811 & 1.8 & 1175 & 1 & \\
\hline 1 & $10 \mathrm{~A}$ & 0.0 & 44.8 & 5.1 & 13 & 1 & & 0.0 & & & & 0.0 & & & 0.0 & & & \\
\hline 1 & 11 & 123.8 & 61.0 & 10.9 & 1 & 1 & 4 & 2.0 & 1 & 2 & 3 & 2.0 & 6 & 1989 & 1.6 & 347 & & \\
\hline 1 & $11 \mathrm{~A}$ & 113.1 & 64.3 & 6.1 & 1 & 1 & 3 & 1.0 & 1 & 2 & 3 & 2.5 & 7 & 1986 & 1.2 & 325 & & \\
\hline 1 & $11 \mathrm{~B}$ & 224.7 & 77.0 & 32.8 & 1 & 1 & 5 & 2.0 & 1 & 2 & 5 & 2.5 & 11 & 1986 & 2.1 & 718 & & \\
\hline 1 & $11 \mathrm{C}$ & 95.4 & 54.2 & 6.0 & 1 & 1 & 4 & 2.0 & 1 & 2 & 3 & 2.5 & 7 & 1986 & 0.8 & 325 & & \\
\hline 1 & 11D & 94.1 & 67.5 & 16.8 & 1 & 1 & 4 & 2.0 & 1 & 2 & 3 & 2.0 & 7 & 1988 & 0.9 & 355 & & \\
\hline 1 & $11 \mathrm{E}$ & 0.0 & 46.8 & 6.5 & 13 & 1 & & 0.0 & & & & 0.0 & & & 0.0 & 325 & & \\
\hline 1 & $11 \mathrm{~F}$ & 94.4 & 55.0 & 6.6 & 1 & 1 & 4 & 1.0 & 1 & 2 & 3 & 2.0 & 6 & 1987 & 1.3 & 325 & & \\
\hline 1 & $11 \mathrm{G}$ & 0.0 & 54.9 & 12.2 & 13 & 1 & & 0.0 & & & & 0.0 & & & 0.0 & 347 & & \\
\hline 1 & $11 \mathrm{H}$ & 80.1 & 61.1 & 10.9 & 1 & 1 & 3 & 1.0 & 1 & 2 & 2 & 2.0 & 5 & 1988 & 1.3 & 350 & & \\
\hline 1 & 12 & 99.9 & 52.6 & 5.0 & 1 & 1 & 4 & 1.0 & 1 & 2 & 3 & 1.5 & 5 & 1979 & 0.8 & 954 & & \\
\hline 1 & $12 A$ & 63.7 & 52.1 & 4.5 & 1 & 1 & 3 & 1.0 & 1 & 2 & 3 & 1.0 & 5 & 1978 & 1.0 & 340 & & \\
\hline 1 & $12 B$ & 59.7 & 53.8 & 5.8 & 1 & 1 & 3 & 1.0 & 1 & 2 & 2 & 1.0 & 4 & 1979 & 0.9 & 1080 & & \\
\hline 1 & 14 & 54.7 & 44.7 & 3.0 & 1 & 1 & 2 & 1.0 & 1 & 3 & 2 & 1.0 & 5 & 1970 & 1.1 & 200 & & \\
\hline 1 & 15 & 72.6 & 60.0 & 10.0 & 1 & 1 & 3 & 1.0 & 1 & 2 & 3 & 1.0 & 5 & 1968 & 1.1 & 934 & & \\
\hline 1 & $15 \mathrm{~A}$ & 5.0 & 60.0 & 10.0 & 1 & 1 & & 0.0 & & & & 0.0 & & & 0.0 & & & \\
\hline 1 & 16 & 0.0 & 26.7 & 24.0 & 13 & 1 & & 0.0 & & & & 0.0 & & & 0.0 & 100 & & \\
\hline 1 & 17 & 0.0 & 7.5 & 5.0 & 13 & 1 & & 0.0 & & & & 0.0 & & & 0.0 & & & \\
\hline 1 & $17 \mathbf{A}$ & 0.0 & 15.0 & 10.0 & 13 & 1 & & 0.0 & & & & 0.0 & & & 0.0 & & & \\
\hline 1 & 18 & 0.0 & 11.3 & 7.5 & 13 & 1 & & 0.0 & & & & 0.0 & & & 0.0 & & & \\
\hline 1 & 19 & 276.1 & 80.5 & 52.0 & 1 & 1 & 5 & 1.5 & 1 & 2 & 5 & 3.0 & 11 & 1850 & 2.1 & 2180 & 1 & \\
\hline
\end{tabular}




\begin{tabular}{|c|c|c|c|c|c|c|c|c|c|c|c|c|c|c|c|c|c|c|}
\hline Map & Lot & $\begin{array}{l}\text { Bldg. } \\
\text { Value }\end{array}$ & $\begin{array}{l}\text { Land } \\
\text { Value }\end{array}$ & Acres & $\begin{array}{l}\text { Land } \\
\text { Use }\end{array}$ & Zoning & $\begin{array}{l}\text { Bldg. } \\
\text { Grade }\end{array}$ & $\begin{array}{l}\text { \# of } \\
\text { Stories }\end{array}$ & $\begin{array}{l}\text { Occu- } \\
\text { pancy }\end{array}$ & $\begin{array}{l}\text { Heat } \\
\text { Type }\end{array}$ & $\begin{array}{l}\text { \# of } \\
\text { Beds }\end{array}$ & $\begin{array}{l}\text { of } \\
\text { Baths }\end{array}$ & $\begin{array}{l}\text { Total } \\
\text { Rooms }\end{array}$ & $\begin{array}{l}\text { Year } \\
\text { Built }\end{array}$ & $\begin{array}{l}\text { 1st } \\
\text { Floor }\end{array}$ & Frontage & $\begin{array}{l}\text { Wet- } \\
\text { lands }\end{array}$ & $\begin{array}{l}\text { Water- } \\
\text { shed }\end{array}$ \\
\hline 1 & $19 \mathrm{~A}$ & 0.0 & 52.1 & 10.0 & 13 & 1 & & 0.0 & & & & 0.0 & & & 0.0 & 50 & & \\
\hline i & 20 & 135.9 & 25.0 & 0.4 & 1 & 1 & 5 & 2.0 & 1 & 2 & 4 & 2.0 & 10 & 1703 & 1.0 & 210 & & \\
\hline 1 & 21 & 0.0 & 44.2 & 4.8 & 13 & 3 & & 0.0 & & & & 0.0 & & & 0.0 & 850 & & \\
\hline 1 & 23 & 0.0 & 0.0 & 0.0 & 1 & 1 & 3 & 1.0 & 1 & 2 & 1 & 1.0 & 5 & 1800 & 0.8 & & & \\
\hline 1 & 23 & 150.3 & 71.5 & 25.0 & 1 & 1 & 4 & 1.0 & 1 & 2 & 3 & 1.0 & 7 & 1750 & 1.3 & 1060 & & \\
\hline 1 & $23 \mathrm{~A}$ & 0.0 & 48.4 & 7.6 & 13 & 1 & & 0.0 & & & & 0.0 & & & 0.0 & & & \\
\hline 1 & 24 & 0.0 & 68.6 & 34.2 & 13 & 1 & & 0.0 & & & & 0.0 & & & 0.0 & 600 & & \\
\hline 1 & 25 & 74.2 & 75.9 & 30.9 & 1 & 1 & 4 & 1.0 & 1 & 2 & 3 & 1.5 & 7 & 1830 & 0.9 & 442 & & \\
\hline 1 & $25 \mathrm{~A}$ & 102.9 & 67.9 & 20.5 & 1 & 1 & 4 & 2.0 & 1 & 2 & 2 & 2.0 & 4 & 1982 & 1.1 & 388 & & \\
\hline 1 & 26 & 22.5 & 36.6 & 1.0 & 1 & 1 & 2 & 1.0 & 1 & 2 & 3 & 2.0 & 5 & 1965 & 1.3 & 245 & & \\
\hline 1 & 27 & 141.7 & 105.9 & 98.0 & 1 & 1 & 4 & 1.5 & 1 & 2 & 4 & 1.0 & 11 & 1800 & 1.4 & 500 & & \\
\hline 1 & 28 & 0.0 & 35.9 & 2.5 & 13 & 1 & & 0.0 & & & & 0.0 & & & 0.0 & 700 & & \\
\hline 1 & 30 & 80.4 & 38.3 & 1.6 & 6 & 1 & 2 & 0.0 & & 2 & & 0.0 & & 1975 & 1.6 & & & \\
\hline 1 & 31 & 0.0 & 5.9 & 0.5 & 13 & 1 & & 0.0 & & & & 0.0 & & & 0.0 & 150 & & \\
\hline 1 & 32 & 0.0 & 4.0 & 0.3 & 13 & 1 & & 0.0 & & & & 0.0 & & & 0.0 & 100 & & \\
\hline 1 & 33 & 71.7 & 58.6 & 9.0 & 1 & 1 & 3 & 1.0 & 1 & 2 & 3 & 1.0 & 5 & 1969 & 1.0 & 700 & & \\
\hline 1 & 34 & 0.0 & 4.4 & 2.5 & 13 & 1 & & 0.0 & & & & 0.0 & & & 0.0 & 250 & & \\
\hline 1 & 35 & 0.0 & 8.7 & 2.5 & 13 & 1 & & 0.0 & & & & 0.0 & & & 0.0 & 150 & & \\
\hline 1 & 36 & 0.0 & 60.8 & 19.0 & 13 & 1 & & 0.0 & & & & 0.0 & & & 0.0 & 750 & & \\
\hline 1 & 37 & 10.0 & 79.7 & 41.9 & 1 & 1 & 3 & 1.0 & 1 & 2 & 2 & 1.0 & 6 & 1800 & 0.9 & 1900 & & \\
\hline 1 & $37 \mathrm{~A}$ & 75.3 & 52.3 & 4.9 & 1 & 1 & 3 & 1.0 & 1 & 2 & 3 & 1.0 & 6 & 1989 & 1.2 & 300 & & \\
\hline 1 & 37B & 0.0 & 45.1 & 5.3 & 13 & 1 & & 0.0 & & & & 0.0 & & & 0.0 & & & \\
\hline 1 & 38 & 76.2 & 53.5 & 5.6 & 1 & $i$ & 4 & 1.0 & 1 & 2 & 3 & 1.0 & 6 & 1780 & 1.2 & 800 & & \\
\hline 1 & $38 \mathrm{~A}$ & 0.0 & 58.5 & 15.8 & 13 & 1 & & 0.0 & & & & 0.0 & & & 0.0 & & & \\
\hline 1 & 39 & 59.0 & 13.2 & 0.1 & 72 & i & 1 & 0.0 & & 2 & & 0.0 & & 1864 & 0.9 & 150 & & \\
\hline 1 & 40 & 0.0 & 13.6 & 7.0 & 78 & 1 & & 0.0 & & & & 0.0 & & & 0.0 & 450 & & \\
\hline 1 & 41 & 88.4 & 56.2 & 8.5 & 1 & 1 & 4 & 1.5 & 1 & 2 & 3 & 2.0 & 5 & 1985 & 1.1 & 480 & 1 & \\
\hline 1 & 41D & 104.5 & 67.6 & 19.8 & 1 & 1 & 4 & 2.0 & 1 & 4 & 4 & 2.5 & 8 & 1975 & 1.1 & 751 & & \\
\hline 1 & $41 E$ & 104.5 & 55.6 & 6.8 & 1 & 1 & 4 & 1.5 & 1 & 2 & 3 & 2.0 & 5 & 1976 & 1.4 & 347 & & \\
\hline 1 & $41 \mathrm{G}$ & 85.8 & 53.8 & 5.8 & 1 & 1 & 3 & 1.0 & 1 & 2 & 3 & 1.5 & 7 & 1975 & 1.3 & 301 & & \\
\hline 1 & $41 \mathrm{H}$ & 90.0 & 56.8 & 7.8 & 1 & 1 & 3 & 1.0 & 1 & 2 & 3 & 2.0 & 6 & 1977 & 1.3 & 390 & & \\
\hline 1 & $41 I$ & 72.9 & 63.5 & 12.7 & 1 & 1 & 4 & 1.0 & 1 & 2 & 2 & 1.0 & 3 & 1979 & 0.8 & 500 & & \\
\hline 1 & $41 \mathrm{~J}$ & 90.5 & 62.0 & 11.5 & $i$ & i & 4 & 1.0 & 1 & 5 & 3 & 2.0 & 6 & 1984 & 0.9 & 1690 & & \\
\hline 1 & 42 & 0.0 & 60.6 & 21.0 & 13 & 1 & & 0.0 & & & & 0.0 & & & 0.0 & & 1 & \\
\hline 1 & 43 & 0.0 & 44.6 & 5.0 & 13 & i & & 0.0 & & & & 0.0 & & & 0.0 & 512 & 1 & \\
\hline 1 & $43 A$ & 0.0 & 44.0 & 4.6 & 13 & 1 & & 0.0 & & & & 0.0 & & & 0.0 & & & \\
\hline 1 & 43B & 271.9 & 58.7 & 22.4 & 1 & 1 & 5 & 1.0 & 1 & 3 & 4 & 3.0 & 8 & 1981 & 5.0 & & & \\
\hline 1 & 43D & 99.3 & 52.6 & 5.0 & 1 & 1 & 5 & 1.5 & 1 & 3 & 1 & 1.0 & 4 & 1981 & 1.3 & & & \\
\hline 1 & 43E & 58.4 & 66.6 & 15.0 & 1 & 1 & 3 & 1.0 & 2 & 3 & 1 & 1.0 & 3 & 1987 & 0.6 & & & \\
\hline 1 & 44 & 99.7 & 36.6 & 1.0 & 76 & 1 & 2 & 0.0 & & & & 0.0 & & 1850 & 1.8 & 100 & & \\
\hline
\end{tabular}




\begin{tabular}{|c|c|c|c|c|c|c|c|c|c|c|c|c|c|c|c|c|c|c|}
\hline Map & Lot & $\begin{array}{l}\text { Bldg. } \\
\text { Value }\end{array}$ & $\begin{array}{l}\text { Land } \\
\text { Value }\end{array}$ & Acres & $\begin{array}{l}\text { Land } \\
\text { Use }\end{array}$ & Zoning & $\begin{array}{l}\text { Bldg. } \\
\text { Grade }\end{array}$ & $\begin{array}{l}\text { \# of } \\
\text { Stories }\end{array}$ & $\begin{array}{l}\text { Occu- } \\
\text { pancy }\end{array}$ & $\begin{array}{l}\text { Heat } \\
\text { Type }\end{array}$ & $\begin{array}{l}\text { Hof } \\
\text { Beds }\end{array}$ & $\begin{array}{l}\text { \# of } \\
\text { Baths }\end{array}$ & $\begin{array}{l}\text { Total } \\
\text { Rooms }\end{array}$ & $\begin{array}{l}\text { Year } \\
\text { Built }\end{array}$ & $\begin{array}{l}\text { 1st } \\
\text { Floor }\end{array}$ & Frontage & $\begin{array}{l}\text { Wet- } \\
\text { lands }\end{array}$ & $\begin{array}{l}\text { Water- } \\
\text { shed }\end{array}$ \\
\hline 1 & 45 & 72.6 & 37.6 & 1.3 & 78 & 1 & 2 & 0.0 & & & & 0.0 & & 1952 & 1.7 & 190 & & \\
\hline 1 & 46 & 82.5 & 79.5 & 42.9 & 1 & 1 & 4 & 1.0 & 1 & 2 & 4 & 2.0 & 8 & 1840 & 1.2 & 750 & & \\
\hline 1 & $46 \mathrm{~A}$ & 68.5 & 38.2 & 13.1 & $i$ & 1 & 3 & 1.0 & $i$ & 2 & 2 & 1.0 & 3 & 1989 & 1.0 & & & \\
\hline 1 & 47 & 43.2 & 64.2 & 25.0 & 1 & 1 & 2 & 1.0 & 0 & 1 & 2 & 2.0 & 5 & 1760 & 1.1 & 1864 & 1 & \\
\hline 1 & $47 \mathrm{~A}$ & 0.0 & 64.2 & 25.0 & 13 & 1 & & 0.0 & & & & 0.0 & & & 0.0 & & 1 & \\
\hline 1 & $47 \mathrm{~B}$ & 0.0 & 64.2 & 25.0 & 13 & 1 & & 0.0 & & & & 0.0 & & & 0.0 & & 1 & \\
\hline 1 & 48 & 59.7 & 54.5 & 7.0 & 1 & 1 & 3 & 1.0 & 1 & 2 & 1 & 1.0 & 5 & 1969 & 1.1 & 700 & 1 & \\
\hline 1 & 49 & 0.0 & 52.1 & 10.0 & 13 & 1 & & 0.0 & & & & 0.0 & & & 0.0 & 560 & 1 & \\
\hline 1 & 50 & 117.3 & 97.5 & 72.0 & 1 & 1 & 4 & 1.5 & 1 & 2 & 3 & 1.5 & 7 & 1763 & 1.8 & 1000 & 1 & \\
\hline 1 & 51 & 0.0 & 44.2 & 5.0 & 13 & 1 & & 0.0 & & & & 0.0 & & & 0.0 & 650 & 1 & \\
\hline 1 & $51 \mathrm{~A}$ & 84.9 & 52.6 & 5.0 & 1 & 1 & 3 & 2.0 & 1 & 2 & 3 & 1.0 & 6 & 1979 & 1.0 & 500 & 1 & \\
\hline 1 & 52 & 62.0 & 52.6 & 6.1 & 1 & 1 & 3 & 1.0 & 1 & 2 & 3 & 1.0 & 5 & 1969 & 1.0 & 500 & & \\
\hline 1 & $52 \mathrm{~A}$ & 93.1 & 53.0 & 5.3 & $i$ & 1 & 4 & 1.5 & 1 & 2 & 3 & 2.0 & 6 & 1987 & 1.0 & 400 & & \\
\hline 1 & 53 & 83.1 & 52.1 & 4.6 & 1 & 1 & 3 & 1.5 & 1 & 2 & 3 & 2.0 & 5 & 1978 & 1.2 & 300 & & \\
\hline 1 & $53 \mathrm{~A}$ & 85.1 & 52.8 & 5.1 & 1 & 1 & 4 & 1.5 & 1 & 2 & 3 & 1.5 & 5 & 1986 & 0.8 & 300 & & \\
\hline 1 & $53 B$ & 96.8 & 52.2 & 4.7 & 1 & 1 & 4 & 1.5 & 1 & 2 & 3 & 2.0 & 7 & 1989 & 1.0 & 300 & & \\
\hline 1 & $53 \mathrm{C}$ & 69.8 & 52.8 & 5.1 & 1 & 1 & 3 & 1.0 & 1 & 2 & 3 & 1.5 & 5 & 1988 & 1.0 & 467 & & \\
\hline 1 & 54 & 0.0 & 90.3 & 84.0 & 13 & 1 & & 0.0 & & & & 0.0 & & & 0.0 & & 1 & \\
\hline 1 & 55 & 72.5 & 53.4 & 5.5 & 1 & 1 & 3 & 1.0 & 1 & 2 & 2 & 1.5 & 5 & 1987 & 1.2 & 50 & & \\
\hline 1 & 56 & 79.4 & 68.8 & 23.0 & 1 & 1 & 3 & 1.5 & 1 & 2 & 3 & 2.0 & 5 & 1975 & 1.0 & 400 & & \\
\hline 1 & 57 & 93.3 & 60.1 & 10.0 & 1 & $i$ & 4 & 1.0 & $i$ & 2 & 4 & 1.0 & 10 & 1797 & 1.4 & 602 & & \\
\hline 1 & $57 \mathrm{~A}$ & 67.0 & 60.9 & 10.8 & 1 & 1 & 3 & 1.5 & 1 & 2 & 3 & 1.5 & 6 & 1974 & 1.2 & 375 & & \\
\hline 1 & $57 \mathrm{~B}$ & 0.0 & 79.6 & 94.0 & 13 & 1 & & 0.0 & & & & 0.0 & & & 0.0 & 710 & & \\
\hline 1 & 58 & 98.4 & 94.2 & 65.0 & 1 & 1 & 5 & 2.0 & 1 & 2 & 3 & 2.0 & 7 & 1779 & 1.3 & 1350 & & \\
\hline 1 & 59 & 0.4 & 52.6 & 12.0 & 13 & i & & 0.0 & & & & 0.0 & & & 0.0 & 920 & & \\
\hline 1 & 60 & 101.5 & 55.0 & 6.6 & 1 & $i$ & 3 & 1.0 & 1 & 2 & 3 & 2.0 & 8 & 1978 & 1.7 & 430 & & \\
\hline 1 & $60 A$ & 85.2 & 52.9 & 5.1 & 1 & $i$ & 4 & 1.0 & 1 & 3 & 2 & 1.5 & 4 & 1982 & 1.2 & 1300 & & \\
\hline 1 & 61 & 0.0 & 63.8 & 23.9 & 13 & 1 & & 0.0 & & & & 0.0 & & & 0.0 & 1040 & & \\
\hline 1 & $61 A$ & 0.0 & 10.6 & 5.0 & 13 & 1 & & 0.0 & & & & 0.0 & & & 0.0 & & & \\
\hline 1 & 62 & 0.0 & 99.2 & 91.5 & 13 & 1 & & 0.0 & & & & 0.0 & & & 0.0 & 2450 & 1 & \\
\hline 1 & $62 A$ & 84.5 & 68.2 & 18.0 & 1 & 1 & 4 & 1.0 & 1 & 2 & 3 & 2.0 & 7 & 1740 & 1.0 & & & \\
\hline 1 & 63 & 0.0 & 58.6 & 15.0 & 13 & 1 & & 0.0 & & & & 0.0 & & & 0.0 & 544 & & \\
\hline 1 & 64 & 131.0 & 52.8 & 5.1 & 1 & 1 & 4 & 2.0 & 1 & 2 & 4 & 2.5 & 9 & 1900 & 1.4 & 669 & & \\
\hline 1 & 64 & 0.0 & 0.0 & 0.0 & 1 & 1 & 2 & 1.0 & 1 & 2 & 1 & 1.0 & 3 & 1900 & 0.8 & & & \\
\hline 1 & $64 A$ & 71.5 & 53.8 & 5.8 & 1 & 1 & 3 & 1.0 & 1 & 2 & 3 & 1.5 & 6 & 1975 & 1.1 & 500 & & \\
\hline 1 & $64 \mathrm{~B}$ & 101.9 & 54.0 & 5.9 & 1 & 1 & 4 & 1.5 & 1 & 2 & 3 & 2.0 & 7 & 1976 & 1.1 & 300 & & \\
\hline 1 & $64 \mathrm{C}$ & 75.6 & 58.5 & 8.9 & 1 & 1 & 3 & 1.5 & 1 & 2 & 3 & 2.0 & 5 & 1976 & 1.0 & 300 & & \\
\hline 1 & $64 D$ & 0.0 & 50.0 & 8.6 & 13 & 1 & & 0.0 & & & & 0.0 & & & 0.0 & 300 & & \\
\hline 1 & 65 & 0.2 & 54.7 & 12.0 & 13 & 1 & & 0.0 & & & & 0.0 & & & 0.0 & 643 & & \\
\hline 1 & 66 & 0.0 & 72.0 & 38.0 & 13 & 1 & & 0.0 & & & & 0.0 & & & 0.0 & & 1 & \\
\hline
\end{tabular}




\begin{tabular}{|c|c|c|c|c|c|c|c|c|c|c|c|c|c|c|c|c|c|c|}
\hline Map & Lot & $\begin{array}{l}\text { Bldg. } \\
\text { Value }\end{array}$ & $\begin{array}{l}\text { Land } \\
\text { Value }\end{array}$ & Acres & $\begin{array}{l}\text { Land } \\
\text { Use }\end{array}$ & Zoning & $\begin{array}{l}\text { Bldg. } \\
\text { Grade }\end{array}$ & $\begin{array}{l}\text { \# of } \\
\text { Stories }\end{array}$ & $\begin{array}{l}\text { Occu- } \\
\text { pancy }\end{array}$ & $\begin{array}{l}\text { Heat } \\
\text { Type }\end{array}$ & $\begin{array}{l}\text { \# of } \\
\text { Beds }\end{array}$ & $\begin{array}{l}\text { \# of } \\
\text { Baths }\end{array}$ & $\begin{array}{l}\text { Total } \\
\text { Rooms }\end{array}$ & $\begin{array}{l}\text { Year } \\
\text { Built }\end{array}$ & $\begin{array}{l}\text { 1st } \\
\text { Floor }\end{array}$ & Frontage & $\begin{array}{l}\text { Wet- } \\
\text { lands }\end{array}$ & $\begin{array}{l}\text { Water- } \\
\text { ahed }\end{array}$ \\
\hline 1 & $66 \mathrm{~A}$ & 0.0 & 14.6 & 10.2 & 13 & 1 & & 0.0 & & & & 0.0 & & & 0.0 & & 1 & \\
\hline 1 & $66 \mathrm{~B}$ & 88.7 & 54.1 & 6.0 & 1 & 1 & 3 & 1.0 & 1 & 2 & 4 & 2.0 & 7 & 1979 & 2.1 & 300 & & \\
\hline 1 & 67 & 43.2 & 74.1 & 39.2 & 1 & 1 & 2 & 1.0 & 1 & 2 & 2 & 1.0 & 4 & 1973 & 0.8 & 310 & & \\
\hline 1 & $67 \mathrm{~A}$ & 67.4 & 54.9 & 5.9 & 1 & 1 & 3 & 1.0 & 1 & 2 & 3 & 1.0 & 5 & 1978 & 1.0 & 300 & & \\
\hline 1 & 68 & 77.9 & 61.6 & 15.0 & 1 & 1 & 3 & 2.0 & 1 & 4 & 2 & 1.0 & 5 & 1980 & 1.2 & 300 & 1 & \\
\hline 1 & $68 \mathrm{~A}$ & 0.0 & 64.3 & 30.0 & 13 & 1 & & 0.0 & & & & 0.0 & & & 0.0 & 479 & 1 & \\
\hline 1 & 68B & 0.0 & 58.6 & 15.0 & 13 & 1 & & 0.0 & & & & 0.0 & & & 0.0 & 300 & 1 & \\
\hline 1 & 69 & 103.0 & 42.6 & 2.5 & 1 & 1 & 4 & 1.5 & 2 & 2 & 4 & 2.0 & 6 & 1880 & 1.5 & 300 & & \\
\hline 1 & 70 & 0.0 & 81.9 & 95.2 & 13 & 1 & & 0.0 & & & & 0.0 & & & 0.0 & 900 & & \\
\hline 1 & $70 \mathrm{~B}$ & 0.2 & 46.1 & 6.0 & 12 & 1 & & 0.0 & & & & 0.0 & & & 0.0 & 302 & & \\
\hline 1 & $70 \mathrm{C}$ & 0.0 & 44.3 & 4.8 & 13 & 1 & & 0.0 & & & & 0.0 & & & 0.0 & & & \\
\hline 1 & 72 & 0.0 & 89.3 & 71.0 & 13 & 1 & & 0.0 & & & & 0.0 & & & 0.0 & 914 & & \\
\hline 2 & 1 & 0.0 & 13.5 & 9.0 & 13 & 1 & & 0.0 & & & & 0.0 & & & 0.0 & & 1 & \\
\hline 2 & 3 & 63.4 & 79.6 & 47.7 & 1 & 1 & 3 & 1.0 & 1 & 2 & 3 & 2.0 & 6 & 1779 & 1.2 & 480 & 1 & \\
\hline 2 & 3 & 12.6 & 0.0 & 0.0 & 5 & 1 & 2 & 0.0 & & 1 & & 0.0 & 1 & 1940 & 0.5 & & & \\
\hline 2 & 4 & 68.3 & 38.1 & 1.6 & 1 & 1 & 3 & 1.0 & 1 & 2 & 3 & 1.5 & 6 & 1950 & 1.3 & 302 & & \\
\hline 2 & 5 & 83.0 & 42.7 & 2.5 & 1 & 1 & 3 & 1.5 & 1 & 2 & 4 & 2.0 & 8 & 1950 & 1.5 & 310 & & \\
\hline 2 & 6 & 23.8 & 44.4 & 3.0 & 1 & 1 & 2 & 1.0 & 1 & 2 & 1 & 1.0 & 4 & 1947 & 1.0 & 200 & & \\
\hline 2 & 7 & 81.2 & 68.6 & 20.0 & 1 & 1 & 4 & 1.0 & 1 & 2 & 3 & 1.0 & 6 & 1790 & 1.3 & 1350 & & \\
\hline 2 & 8 & 0.0 & 0.0 & 0.0 & 1 & 1 & 2 & 1.0 & 1 & 2 & 2 & 1.0 & 4 & 1900 & 0.8 & & & \\
\hline 2 & 8 & 102.1 & 52.9 & 5.1 & 1 & 1 & 3 & 1.0 & 1 & 2 & 2 & 1.0 & 5 & 1826 & 1.4 & 522 & 1 & \\
\hline 2 & $8 \mathrm{~A}$ & 120.7 & 52.9 & 5.2 & 1 & 1 & 4 & 2.0 & 1 & 2 & 3 & 2.5 & 6 & 1988 & 0.9 & 300 & & \\
\hline 2 & $8 B$ & 0.0 & 44.5 & 4.9 & 13 & 1 & & 0.0 & & & & 0.0 & & & 0.0 & 362 & & \\
\hline 2 & $8 C$ & 6.8 & 65.4 & 21.7 & 1 & 1 & 1 & 1.0 & 1 & 1 & 0 & 0.0 & 1 & 1970 & 0.4 & 436 & 1 & \\
\hline 2 & 9 & 50.9 & 53.7 & 5.8 & 1 & 1 & 3 & 1.0 & 1 & 2 & 3 & 1.0 & 4 & 1950 & 0.8 & 970 & & \\
\hline 2 & 10 & 80.3 & 53.7 & 5.8 & 1 & 1 & 3 & 1.0 & 1 & 2 & 3 & 1.5 & 6 & 1966 & 1.2 & 600 & & \\
\hline 2 & 11 & 120.9 & 98.0 & 73.3 & 1 & 1 & 5 & 1.5 & 1 & 2 & 4 & 2.0 & 7 & 1850 & 1.4 & 1350 & & \\
\hline 2 & 12 & 358.4 & 110.2 & 110.0 & 1 & 1 & 9 & 1.0 & 1 & 2 & 3 & 3.5 & 10 & 1976 & 2.9 & 70 & 1 & \\
\hline 2 & 13 & 80.5 & 69.2 & 19.5 & 1 & 1 & 3 & 1.0 & 1 & 2 & 3 & 2.5 & 7 & 1790 & 1.4 & 810 & & \\
\hline 2 & 14 & 120.5 & 89.2 & 55.0 & 1 & 1 & 4 & 2.0 & 1 & 2 & 4 & 2.0 & 8 & 1973 & 1.6 & 350 & 1 & \\
\hline 2 & $14 \mathrm{~A}$ & 108.9 & 52.3 & 4.8 & 1 & 1 & 4 & 1.0 & 1 & 2 & 3 & 2.0 & 7 & 1973 & 1.2 & 900 & & \\
\hline 2 & 14AI & 75.3 & 55.5 & 6.9 & 1 & 1 & 3 & 2.0 & 1 & 2 & 3 & 2.0 & 6 & 1973 & 0.7 & & & \\
\hline 2 & 15 & 93.6 & 37.8 & 1.4 & 1 & 1 & 3 & 2.0 & 1 & 2 & 4 & 1.5 & 6 & 1967 & 1.1 & 250 & & \\
\hline 2 & 16 & 67.7 & 43.1 & 2.8 & 1 & 1 & 3 & 1.0 & 1 & 2 & 3 & 2.0 & 7 & 1963 & 1.1 & 225 & & \\
\hline 2 & 17 & 84.1 & 102.0 & 84.0 & 1 & 1 & 3 & 1.0 & 1 & 2 & 3 & 1.5 & 9 & 1790 & 1.5 & 350 & 1 & \\
\hline 2 & 18 & 0.0 & 45.4 & 7.0 & 13 & 1 & & 0.0 & & & & 0.0 & & & 0.0 & 1100 & 1 & \\
\hline 2 & 19 & 66.5 & 40.1 & 2.0 & 1 & 1 & 3 & 1.0 & 1 & 2 & 3 & 1.0 & 5 & 1967 & 1.0 & 210 & 1 & \\
\hline 2 & $19 \mathrm{~A}$ & 0.0 & 44.6 & 6.0 & 13 & 1 & & 0.0 & & & & 0.0 & & & 0.0 & & 1 & \\
\hline 2 & 20 & 96.1 & 52.7 & 5.0 & 1 & 1 & 3 & 2.0 & 1 & 2 & 3 & 1.0 & 8 & 1922 & 0.9 & 800 & & \\
\hline 2 & 20 & 0.0 & 0.0 & 0.0 & 1 & 1 & 2 & 1.0 & 1 & 2 & 2 & 1.0 & 4 & 1922 & 0.6 & & & \\
\hline
\end{tabular}




\begin{tabular}{|c|c|c|c|c|c|c|c|c|c|c|c|c|c|c|c|c|c|c|}
\hline Map & Lot & $\begin{array}{l}\text { Bldg. } \\
\text { Value }\end{array}$ & $\begin{array}{l}\text { Land } \\
\text { Value }\end{array}$ & Acres & $\begin{array}{l}\text { Land } \\
\text { Use }\end{array}$ & Zoning & $\begin{array}{l}\text { Bldg. } \\
\text { Grade }\end{array}$ & $\begin{array}{l}\text { " of } \\
\text { Stories }\end{array}$ & $\begin{array}{l}\text { Occu- } \\
\text { pancy }\end{array}$ & $\begin{array}{l}\text { Heat } \\
\text { Type }\end{array}$ & $\begin{array}{l}\text { \# of } \\
\text { Beds }\end{array}$ & $\begin{array}{l}\text { of } \\
\text { Baths }\end{array}$ & $\begin{array}{l}\text { Total } \\
\text { Rooms }\end{array}$ & $\begin{array}{l}\text { Year } \\
\text { Built }\end{array}$ & $\begin{array}{l}\text { 1st } \\
\text { Floor }\end{array}$ & Frontage & $\begin{array}{l}\text { Wet- } \\
\text { lands }\end{array}$ & $\begin{array}{l}\text { Water- } \\
\text { shed }\end{array}$ \\
\hline 2 & 21 & 122.0 & 59.3 & 25.0 & 1 & 1 & 4 & 1.0 & 1 & 2 & 3 & 2.0 & 6 & 1985 & 1.7 & 450 & 1 & \\
\hline 2 & 22 & 76.9 & 38.8 & 1.7 & 1 & 1 & 3 & 1.0 & 1 & 2 & 2 & 2.0 & 5 & 1986 & 1.0 & 315 & 1 & \\
\hline 2 & 23 & 0.0 & 0.0 & 0.0 & 1 & 1 & 2 & 1.0 & 1 & 2 & 1 & 1.0 & 5 & 1944 & 0.7 & & & \\
\hline 2 & 23 & 108.5 & 37.3 & 1.2 & 1 & 1 & 3 & 1.0 & 1 & 2 & 4 & 2.0 & 6 & 1958 & 2.1 & 160 & & \\
\hline 2 & 24 & 63.6 & 53.0 & 7.0 & 1 & 1 & 3 & 1.0 & 1 & 2 & 2 & 2.0 & 4 & 1950 & 1.2 & 260 & & \\
\hline 2 & 26 & 0.0 & 4.2 & 12.0 & 13 & 1 & & 0.0 & & & & 0.0 & & & 0.0 & & & \\
\hline 2 & 27 & 0.0 & 11.4 & 8.0 & 13 & 1 & & 0.0 & & & & 0.0 & & & 0.0 & 462 & & \\
\hline 2 & 28 & 70.7 & 42.2 & 2.6 & 1 & 1 & 3 & 1.0 & 1 & 2 & 4 & 1.5 & 7 & 1952 & 1.0 & 300 & & \\
\hline 2 & 29 & 0.0 & 32.0 & 1.5 & 80 & 1 & & 0.0 & & & & 0.0 & & & 0.0 & 240 & & \\
\hline 2 & 30 & 63.5 & 52.6 & 5.0 & 1 & 1 & 3 & 1.0 & 1 & 2 & 2 & 1.0 & 4 & 1965 & 1.1 & 30 & 1 & \\
\hline 2 & 31 & 87.8 & 52.6 & 5.0 & 1 & 1 & 4 & 1.0 & 1 & 2 & 2 & 1.0 & 6 & 1900 & 1.2 & 300 & & \\
\hline 2 & $31 \mathrm{~A}$ & 0.0 & 90.0 & 70.2 & 13 & 1 & & 0.0 & & & & 0.0 & & & 0.0 & 600 & 1 & \\
\hline 2 & 33 & 70.7 & 52.2 & 6.0 & 1 & 1 & 3 & 2.0 & 1 & 2 & 3 & 1.5 & 7 & 1940 & 0.9 & 1040 & 1 & \\
\hline 2 & 34 & 81.2 & 48.8 & 4.0 & 1 & 1 & 3 & 2.0 & 1 & 2 & 3 & 1.5 & 7 & 1959 & 0.8 & 438 & 1 & \\
\hline 2 & 35 & 63.8 & 50.6 & 4.3 & 1 & $i$ & 3 & 1.0 & 1 & 2 & 3 & 1.5 & 6 & 1950 & 1.3 & 750 & & \\
\hline 2 & 36 & 73.7 & 84.4 & 48.0 & 1 & 1 & 3 & 1.0 & 1 & 2 & 4 & 1.0 & 10 & 1850 & 1.9 & 1020 & 1 & \\
\hline 2 & 37 & 50.3 & 37.9 & 1.5 & 1 & 1 & 3 & 1.0 & 1 & 2 & 2 & 1.0 & 4 & 1965 & 0.8 & 150 & & \\
\hline 2 & 38 & 25.0 & 99.3 & 82.5 & 1 & 1 & 3 & 1.0 & & 1 & & 0.0 & 1 & 1975 & 0.6 & 85 & 1 & \\
\hline 2 & 39 & 66.9 & 48.8 & 4.0 & 1 & 1 & 3 & 1.0 & 1 & 2 & 2 & 1.5 & 5 & 1935 & 1.3 & 284 & & \\
\hline 2 & 40 & 0.0 & 47.6 & 7.0 & 13 & 1 & & 0.0 & & & & 0.0 & & & 0.0 & 366 & & \\
\hline 2 & 41 & 83.5 & 59.4 & 9.5 & 1 & 1 & 3 & 2.0 & 1 & 4 & 2 & 1.0 & 5 & 1986 & 1.0 & 545 & 1 & \\
\hline 2 & $41 \mathrm{~A}$ & 86.5 & 49.8 & 4.1 & 1 & 1 & 3 & 1.0 & 1 & 2 & 3 & 1.0 & 5 & 1974 & 1.4 & 300 & & \\
\hline 2 & 42 & 59.4 & 73.7 & 27.0 & 1 & 1 & 3 & 1.0 & 1 & 2 & 3 & 1.0 & 5 & 1940 & 1.0 & 1200 & 1 & \\
\hline 2 & 43 & 58.7 & 70.3 & 24.0 & 1 & 1 & 3 & 1.0 & 1 & 2 & 1 & 1.0 & 3 & 1850 & 1.2 & 250 & 1 & \\
\hline 2 & 44 & 59.2 & 104.6 & 89.8 & 1 & 1 & 3 & 1.0 & 1 & 2 & 2 & 1.0 & 6 & 1770 & 0.9 & & 1 & \\
\hline 2 & 45 & 77.8 & 81.8 & 47.0 & 1 & 1 & 3 & 1.0 & 1 & 1 & 3 & 1.0 & 5 & 1981 & 1.1 & 820 & 1 & \\
\hline 2 & 46 & 76.0 & 47.3 & 3.5 & 1 & 1 & 4 & 1.0 & 1 & 2 & 4 & 1.0 & 8 & 1790 & 1.3 & & 1 & \\
\hline 2 & 47 & 0.0 & 90.9 & 77.0 & 13 & 1 & & 0.0 & & & & 0.0 & & & 0.0 & & 1 & \\
\hline 2 & 48 & 46.9 & 54.7 & 6.4 & 1 & 1 & 2 & 1.0 & 1 & 2 & 2 & 1.0 & 5 & 1780 & 1.1 & 263 & & \\
\hline 2 & 49 & 0.0 & 59.0 & 16.0 & 15 & 1 & & 0.0 & & & & 0.0 & & & 0.0 & 680 & & \\
\hline 2 & 50 & 96.7 & 55.4 & 8.7 & 1 & 1 & 4 & 1.0 & 1 & 2 & 3 & 1.0 & 7 & 1755 & 1.3 & 386 & & \\
\hline 2 & 51 & 0.0 & 12.1 & 6.0 & 13 & 1 & & 0.0 & & & & 0.0 & & & 0.0 & 260 & & \\
\hline 2 & 52 & 58.9 & 78.1 & 36.5 & 1 & 1 & 4 & 1.0 & 1 & 2 & 3 & 1.0 & 6 & 1800 & 0.9 & 400 & 1 & \\
\hline 2 & 53 & 55.2 & 62.0 & 11.5 & 1 & 1 & 3 & 1.0 & 1 & 2 & 2 & 1.0 & 5 & 1755 & 1.1 & 1320 & 1 & \\
\hline 2 & 54 & 0.0 & 25.2 & 0.3 & 71 & 1 & & 0.0 & & & & 0.0 & & & 0.0 & 20 & & \\
\hline 2 & 55 & 0.0 & 12.2 & 6.8 & 13 & 1 & & 0.0 & & & & 0.0 & & & 0.0 & 450 & & \\
\hline 2 & $55 \mathrm{~A}$ & 0.0 & 44.8 & 5.1 & 13 & 1 & & 0.0 & & & & 0.0 & & & 0.0 & 347 & & \\
\hline 2 & 56 & 0.0 & 18.1 & 10.0 & 13 & 1 & & 0.0 & & & & 0.0 & & & 0.0 & 550 & & \\
\hline 2 & 57 & 0.0 & 0.0 & 0.0 & 1 & 1 & 4 & 1.0 & 1 & 2 & 2 & 1.0 & 8 & 1850 & 1.2 & & & \\
\hline 2 & 57 & 214.3 & 85.8 & 50.0 & 1 & $i$ & 4 & 2.0 & 2 & 2 & 5 & 2.0 & 12 & 1780 & 1.5 & 1420 & 1 & \\
\hline
\end{tabular}




\begin{tabular}{|c|c|c|c|c|c|c|c|c|c|c|c|c|c|c|c|c|c|c|}
\hline Map & Lot & $\begin{array}{l}\text { Bldg. } \\
\text { Value }\end{array}$ & $\begin{array}{l}\text { Land } \\
\text { Value }\end{array}$ & Acres & $\begin{array}{l}\text { Land } \\
\text { Use }\end{array}$ & Zoning & $\begin{array}{l}\text { Bldg. } \\
\text { Grade }\end{array}$ & $\begin{array}{l}\text { of } \\
\text { Stories }\end{array}$ & $\begin{array}{l}\text { Occu- } \\
\text { pancy }\end{array}$ & $\begin{array}{l}\text { Heat } \\
\text { Type }\end{array}$ & $\begin{array}{l}\text { \# of } \\
\text { Beds }\end{array}$ & $\begin{array}{l}\text { \# of } \\
\text { Baths }\end{array}$ & $\begin{array}{l}\text { Total } \\
\text { Rooms }\end{array}$ & $\begin{array}{l}\text { Year } \\
\text { Built }\end{array}$ & $\begin{array}{l}1 \mathrm{st} \\
\text { Floor }\end{array}$ & Frontage & $\begin{array}{l}\text { Wet- } \\
\text { lands }\end{array}$ & $\begin{array}{l}\text { Water- } \\
\text { shed }\end{array}$ \\
\hline 2 & 58 & 32.7 & 86.4 & 64.0 & 1 & 1 & 3 & 1.0 & 1 & 1 & 1 & 1.0 & 3 & 1935 & 0.5 & 1000 & 1 & \\
\hline 2 & 59 & 17.4 & 54.1 & 10.0 & 11 & 1 & 2 & 1.0 & $i$ & $i$ & 1 & 0.0 & 2 & 1932 & 0.5 & 302 & & \\
\hline 2 & 60 & 71.9 & 44.2 & 2.9 & 1 & 1 & 3 & 1.0 & 1 & 2 & 2 & 1.0 & 3 & 1987 & 0.9 & 208 & & \\
\hline 2 & 61 & 92.5 & 65.8 & 19.0 & $i$ & $i$ & 3 & 1.0 & 1 & 2 & 4 & 1.0 & 10 & 1969 & 1.9 & 290 & & \\
\hline 2 & 62 & 66.4 & 57.6 & 8.3 & 78 & 1 & 3 & 0.0 & & & & 0.0 & & 1965 & 2.0 & 240 & & \\
\hline 2 & 63 & 118.2 & 58.0 & 12.5 & 1 & 1 & 5 & 2.0 & 1 & 2 & 4 & 1.5 & 7 & 1747 & 1.0 & 1650 & & \\
\hline 2 & $63 \mathrm{~A}$ & 86.0 & 53.4 & 5.5 & 1 & 1 & 3 & 1.0 & 1 & 2 & 3 & 1.5 & 7 & 1970 & 1.2 & 300 & & \\
\hline 2 & $63 \mathrm{~B}$ & 70.9 & 52.6 & 5.0 & 1 & 1 & 3 & 1.0 & 1 & 2 & 2 & 2.0 & 4 & 1975 & 1.4 & 466 & & \\
\hline 2 & 64 & 143.0 & 64.0 & 13.0 & 1 & 1 & 5 & 2.0 & 1 & 2 & 3 & 2.5 & 9 & 1756 & 1.8 & 470 & & \\
\hline 2 & 65 & 70.9 & 60.7 & 10.6 & 1 & 1 & 3 & 2.0 & 1 & 2 & 2 & 1.5 & 4 & 1979 & 0.8 & 233 & & \\
\hline 2 & $65 A$ & 57.4 & 53.8 & 5.8 & 1 & 1 & 3 & 1.0 & 1 & 2 & 2 & 1.0 & 5 & 1964 & 1.2 & 320 & & \\
\hline 2 & 66 & 90.9 & 55.9 & 7.2 & 1 & 1 & 5 & 1.0 & 1 & 2 & 2 & 1.0 & 4 & 1850 & 1.3 & 355 & & \\
\hline 2 & 67 & 190.5 & 85.1 & 55.8 & 1 & 1 & 4 & 2.0 & 1 & 2 & 3 & 2.0 & 7 & 1972 & 1.5 & 430 & & \\
\hline 2 & 67 & 0.0 & 0.0 & 0.0 & 1 & 1 & 3 & 1.5 & 1 & 1 & 1 & 1.0 & 3 & 1972 & 0.6 & & & \\
\hline 2 & 68 & 0.0 & 79.3 & 52.0 & 13 & $i$ & & 0.0 & & & & 0.0 & & & 0.0 & 490 & & \\
\hline 2 & $69 A$ & 0.0 & 51.4 & 9.5 & 13 & 1 & & 0.0 & & & & 0.0 & & & 0.0 & 1000 & & \\
\hline 2 & 70 & 25.0 & 19.0 & 0.2 & 72 & 1 & & 0.0 & & 2 & & 0.0 & & 1850 & 0.7 & 80 & & \\
\hline 2 & 71 & 66.3 & 48.8 & 4.0 & 1 & 1 & 3 & 1.5 & 1 & 2 & 4 & 1.0 & 6 & 1931 & 1.1 & 1185 & & \\
\hline 2 & 72 & 45.7 & 37.9 & 1.4 & 1 & 1 & 2 & 1.0 & 1 & 2 & 3 & 1.0 & 5 & 1960 & 1.0 & 300 & & \\
\hline 2 & 73 & 69.0 & 35.3 & 0.9 & 1 & 1 & 3 & 1.0 & 1 & 2 & 3 & 2.0 & 6 & 1962 & 1.1 & 200 & & \\
\hline 2 & 74 & 52.1 & 60.0 & 10.1 & 1 & 1 & 3 & 1.0 & 1 & 4 & 3 & 1.0 & 6 & 1974 & 0.8 & 361 & & \\
\hline 2 & $74 \mathrm{~A}$ & 100.7 & 78.7 & 36.0 & 1 & 1 & 4 & 1.5 & $i$ & 2 & 3 & 2.0 & 8 & 1773 & 1.4 & 775 & & \\
\hline 2 & $74 B$ & 64.2 & 59.3 & 9.4 & 1 & 1 & 3 & 1.0 & 1 & 3 & 2 & 1.0 & 3 & 1984 & 0.9 & 350 & & \\
\hline 2 & $74 \mathrm{C}$ & 0.0 & 0.0 & 0.0 & 1 & 1 & 3 & 2.0 & $i$ & 3 & 1 & 1.0 & 3 & 1985 & 0.8 & & & \\
\hline 2 & $74 C$ & 131.5 & 59.3 & 9.4 & 1 & 1 & 4 & 1.5 & 1 & 4 & 3 & 2.0 & 5 & 1982 & 0.9 & 656 & & \\
\hline 2 & 75 & 63.8 & 55.6 & 7.0 & 1 & 1 & 3 & 1.5 & 1 & 4 & 2 & 1.0 & 5 & 1930 & 1.2 & 480 & & \\
\hline 2 & 76 & 0.0 & 77.6 & 45.5 & 13 & 1 & & 0.0 & & & & 0.0 & & & 0.0 & 475 & & \\
\hline 2 & $76 \mathrm{~A}$ & 129.8 & 52.7 & 5.1 & 1 & 1 & 4 & 2.0 & 1 & 2 & 4 & 2.5 & 8 & 1987 & 1.2 & & & \\
\hline 2 & $76 \mathrm{~B}$ & 0.0 & 44.1 & 4.7 & 13 & 1 & & 0.0 & & & & 0.0 & & & 0.0 & 300 & & \\
\hline 2 & $76 \mathrm{C}$ & 0.0 & 55.1 & 9.3 & 13 & 1 & & 0.0 & & & & 0.0 & & & 0.0 & 300 & & \\
\hline 2 & 77 & 93.6 & 68.1 & 43.0 & 1 & 1 & 3 & 1.0 & 1 & 2 & 3 & 2.0 & 8 & 1968 & 1.7 & & & \\
\hline 2 & 78 & 78.9 & 33.0 & 0.7 & 78 & 1 & 2 & 0.0 & & 2 & & 0.0 & & 1948 & 2.7 & 140 & & \\
\hline 2 & 79 & 134.0 & 85.4 & 48.2 & 1 & 1 & 4 & 1.0 & 1 & 2 & 5 & 3.5 & 8 & 1973 & 2.1 & 319 & & \\
\hline 2 & 80 & 106.2 & 66.2 & 15.7 & 1 & $i$ & 4 & 1.0 & 1 & 2 & 4 & 1.5 & 9 & 1769 & 1.5 & 888 & & \\
\hline 2 & $80 \mathrm{~A}$ & 0.0 & 49.6 & 8.4 & 13 & $i$ & & 0.0 & & & & 0.0 & & & 0.0 & 322 & & \\
\hline 2 & $80 \mathrm{~B}$ & 109.2 & 57.0 & 7.9 & 1 & 1 & 4 & 2.0 & 1 & 3 & 3 & 2.0 & 4 & 1988 & 0.9 & & & \\
\hline 2 & 81 & 48.6 & 40.1 & 2.0 & 1 & 1 & 3 & 1.5 & $i$ & 2 & 3 & 1.0 & 7 & 1936 & 1.0 & 430 & & \\
\hline 3 & 1 & 202.2 & 73.0 & 40.0 & 1 & 1 & 5 & 2.0 & 1 & 2 & 4 & 2.5 & 11 & 1770 & 1.2 & 1300 & 1 & \\
\hline 3 & 2 & 93.0 & 78.5 & 38.0 & 1 & 1 & 4 & 1.5 & 1 & 2 & 4 & 1.0 & 6 & 1860 & 1.1 & 430 & & \\
\hline 3 & 3 & 0.0 & 75.3 & 47.5 & 13 & 1 & & 0.0 & & & & 0.0 & & & 0.0 & 2256 & 1 & \\
\hline
\end{tabular}




\begin{tabular}{|c|c|c|c|c|c|c|c|c|c|c|c|c|c|c|c|c|c|c|}
\hline Map & Lot & $\begin{array}{l}\text { Bldg. } \\
\text { Value }\end{array}$ & $\begin{array}{l}\text { Land } \\
\text { Value }\end{array}$ & Acres & $\begin{array}{l}\text { Land } \\
\text { Use }\end{array}$ & Zoning & $\begin{array}{l}\text { Bldg. } \\
\text { Grade }\end{array}$ & $\begin{array}{l}\text { of } \\
\text { Stories }\end{array}$ & $\begin{array}{l}\text { Occu- } \\
\text { pancy }\end{array}$ & $\begin{array}{l}\text { Heat } \\
\text { Type }\end{array}$ & $\begin{array}{l}\text { "of } \\
\text { Beds }\end{array}$ & $\begin{array}{l}\text { of } \\
\text { Baths }\end{array}$ & $\begin{array}{l}\text { Total } \\
\text { Rooms }\end{array}$ & $\begin{array}{l}\text { Year } \\
\text { Built }\end{array}$ & $\begin{array}{l}\text { lat } \\
\text { Floor }\end{array}$ & Frontage & $\begin{array}{l}\text { Wet- } \\
\text { lands }\end{array}$ & $\begin{array}{l}\text { Water- } \\
\text { shed }\end{array}$ \\
\hline 3 & $3 \mathrm{~A}$ & 0.0 & 58.1 & 23.5 & 13 & 1 & & 0.0 & & & & 0.0 & & & 0.0 & 1000 & & \\
\hline 3 & 3B & 178.7 & 70.8 & 24.8 & 1 & 1 & 4 & 1.0 & 1 & 2 & 3 & 2.5 & 10 & 1989 & 2.9 & 700 & 1 & \\
\hline 3 & 4 & 46.8 & 52.2 & 4.8 & 1 & 1 & 3 & 1.0 & 1 & 2 & 2 & 1.0 & 5 & 1932 & 0.6 & 300 & & \\
\hline 3 & $4 \mathrm{~A}$ & 107.6 & 52.6 & 5.0 & 1 & 1 & 4 & 2.0 & 1 & 2 & 3 & 2.5 & 7 & 1986 & 1.1 & 300 & & 1 \\
\hline 3 & 4B & 59.3 & 52.6 & 5.0 & 1 & 1 & 3 & 1.0 & 1 & 2 & 2 & 1.0 & 4 & 1980 & 0.7 & 345 & & \\
\hline 3 & $4 C$ & 77.8 & 53.1 & 5.3 & 1 & 1 & 4 & 2.0 & 1 & 2 & 2 & 1.0 & 4 & 1986 & 1.4 & 325 & & 1 \\
\hline 3 & 4D & 122.8 & 19.1 & 95.3 & 1 & 1 & 4 & 1.0 & 1 & 2 & 2 & 1.5 & 6 & 1987 & 2.0 & 1473 & 1 & \\
\hline 3 & 4D1 & 182.8 & 60.1 & 10.0 & 1 & 1 & 6 & 2.0 & 1 & 2 & 4 & 3.0 & 8 & 1700 & 1.4 & 1250 & & 1 \\
\hline 3 & 5 & 97.2 & 79.4 & 37.0 & 9 & 1 & 3 & 1.0 & 1 & 2 & 2 & 1.0 & 5 & 1920 & 1.3 & 206 & & \\
\hline 3 & 5 & 109.5 & 50.3 & 4.1 & 1 & 1 & 4 & 2.0 & 1 & 2 & 3 & 3.0 & 6 & 1986 & 0.9 & & & \\
\hline 3 & 6 & 72.3 & 90.0 & 59.0 & 1 & 1 & 3 & 1.5 & 1 & 2 & 3 & 2.0 & 5 & 1900 & 0.9 & 230 & 1 & 1 \\
\hline 3 & 7 & 86.1 & 80.4 & 41.0 & 1 & 1 & 3 & 1.0 & 1 & 2 & 2 & 1.0 & 6 & 1953 & 1.6 & 580 & 1 & 1 \\
\hline 3 & $7 \mathrm{~A}$ & 102.2 & 52.5 & 5.7 & 1 & 1 & 3 & 2.0 & 1 & 2 & 3 & 1.5 & 7 & 1984 & 1.2 & 300 & 1 & 1 \\
\hline 3 & 9 & 0.0 & 0.0 & 0.0 & 1 & 1 & 2 & 1.0 & 1 & 1 & 1 & 1.0 & 3 & 1850 & 0.4 & & & 1 \\
\hline 3 & 9 & 147.7 & 80.4 & 38.5 & 1 & 1 & 5 & 2.0 & 1 & 2 & 5 & 2.0 & 9 & 1850 & 1.8 & 816 & 1 & 1 \\
\hline 3 & $9 A$ & 100.3 & 52.1 & 4.6 & 1 & 1 & 3 & 1.0 & 1 & 2 & 4 & 3.0 & 6 & 1986 & 1.4 & 333 & & 1 \\
\hline 3 & 9A1 & 111.3 & 52.5 & 4.9 & 1 & 1 & 3 & 2.0 & 1 & 2 & 3 & 2.0 & 7 & 1986 & 0.9 & 300 & & 1 \\
\hline 3 & 10 & 0.0 & 45.9 & 5.9 & 13 & 1 & & 0.0 & & & & 0.0 & & & 0.0 & 300 & & \\
\hline 3 & $10 \mathrm{~B}$ & 88.0 & 52.3 & 4.8 & 1 & 1 & 4 & 1.0 & 1 & 2 & 3 & 2.0 & 6 & 1984 & 1.0 & 409 & & \\
\hline 3 & $10 \mathrm{C}$ & 0.0 & 46.0 & 6.7 & 13 & 1 & & 0.0 & & & & 0.0 & & & 0.0 & 300 & & \\
\hline 3 & $10 \mathrm{D}$ & 93.0 & 52.1 & 4.7 & 1 & $i$ & 3 & 1.5 & 1 & 2 & 2 & 2.0 & 6 & 1983 & 1.1 & 300 & & 1 \\
\hline 3 & 11 & 90.0 & 70.6 & 25.5 & 1 & 1 & 3 & 1.0 & 1 & 2 & 3 & 1.5 & 5 & 1966 & 1.3 & & 1 & 1 \\
\hline 3 & $11 \mathrm{~A}$ & 0.0 & 153.5 & 25.6 & 10 & 1 & & 0.0 & & & & 0.0 & & & 0.0 & 537 & & 1 \\
\hline 3 & 12 & 123.9 & 37.9 & 1.5 & 1 & 1 & 4 & 2.0 & 1 & 2 & 3 & 2.5 & 7 & 1988 & 1.2 & 350 & & \\
\hline 3 & 13 & 63.7 & 54.1 & 6.0 & 1 & 1 & 4 & 1.0 & 1 & 2 & 1 & 1.0 & 4 & 1986 & 0.7 & 885 & & \\
\hline 3 & 14 & 0.0 & 23.2 & 0.3 & 15 & 1 & & 0.0 & & & & 0.0 & & & 0.0 & 420 & & \\
\hline 3 & 15 & 0.0 & 6.9 & 0.9 & 13 & 1 & & 0.0 & & & & 0.0 & & & 0.0 & 300 & & \\
\hline 3 & 16 & 31.4 & 72.1 & 51.2 & 1 & 1 & 2 & 2.0 & 1 & 1 & 2 & 1.0 & 3 & 1935 & 0.6 & 2900 & & 1 \\
\hline 3 & $16 \mathrm{~A}$ & 0.0 & 80.7 & 13.5 & 10 & 1 & & 0.0 & & & & 0.0 & & & 0.0 & 240 & & \\
\hline 3 & $16 \mathrm{~B}$ & 78.9 & 52.9 & 5.2 & 1 & 1 & 3 & 1.0 & 1 & 2 & 3 & 2.0 & 6 & 1981 & 1.3 & 370 & & \\
\hline 3 & $16 \mathrm{C}$ & 0.0 & 70.7 & 36.0 & 13 & 1 & & 0.0 & & & & 0.0 & & & 0.0 & 1050 & & \\
\hline 3 & 16D & 0.0 & 32.3 & 1.4 & 15 & 1 & & 0.0 & & & & 0.0 & & & 0.0 & & & \\
\hline 3 & $16 \mathrm{E}$ & 0.0 & 56.6 & 13.6 & 13 & 1 & & 0.0 & & & & 0.0 & & & 0.0 & & & \\
\hline 3 & $16 \mathrm{~F}$ & 0.0 & 52.2 & 10.5 & 13 & 1 & & 0.0 & & & & 0.0 & & & 0.0 & & & \\
\hline 3 & $16 G$ & 0.0 & 62.6 & 22.1 & 13 & 1 & & 0.0 & & & & 0.0 & & & 0.0 & & & \\
\hline 3 & 17 & 0.0 & 41.8 & 4.0 & 15 & 1 & & 0.0 & & & & 0.0 & & & 0.0 & & & \\
\hline 3 & 18 & 42.5 & 15.0 & 3.9 & 4 & 1 & & 0.0 & & & & 0.0 & & & 0.0 & 400 & & \\
\hline 3 & $18 \mathrm{~A}$ & 84.9 & 53.1 & 5.3 & 1 & 1 & 4 & 1.5 & 1 & 2 & 3 & 1.0 & 6 & 1988 & 1.1 & 578 & & \\
\hline 3 & $18 B$ & 76.0 & 54.4 & 6.2 & 1 & 1 & 3 & 1.5 & 1 & 4 & 2 & 2.5 & 5 & 1985 & 0.9 & 580 & & \\
\hline 3 & 19 & 0.0 & 46.9 & 6.5 & 13 & 1 & & 0.0 & & & & 0.0 & & & 0.0 & 330 & & \\
\hline
\end{tabular}




\begin{tabular}{|c|c|c|c|c|c|c|c|c|c|c|c|c|c|c|c|c|c|c|}
\hline Map & Lot & $\begin{array}{l}\text { Bldg. } \\
\text { Value }\end{array}$ & $\begin{array}{l}\text { Land } \\
\text { Value }\end{array}$ & Acres & $\begin{array}{l}\text { Land } \\
\text { Use }\end{array}$ & Zoning & $\begin{array}{l}\text { Bldg. } \\
\text { Grade }\end{array}$ & $\begin{array}{l}\text { of } \\
\text { Stories }\end{array}$ & $\begin{array}{l}\text { Occu- } \\
\text { pancy }\end{array}$ & $\begin{array}{l}\text { Heat } \\
\text { Type }\end{array}$ & $\begin{array}{l}\text { of } \\
\text { Beds }\end{array}$ & $\begin{array}{l}\text { "of } \\
\text { Baths }\end{array}$ & $\begin{array}{l}\text { Total } \\
\text { Rooms }\end{array}$ & $\begin{array}{l}\text { Year } \\
\text { Built }\end{array}$ & $\begin{array}{l}\text { 1st } \\
\text { Floor }\end{array}$ & Frontage & $\begin{array}{l}\text { Wet- } \\
\text { lands }\end{array}$ & $\begin{array}{l}\text { Water- } \\
\text { shed }\end{array}$ \\
\hline 3 & 20 & 0.0 & 88.9 & 70.3 & 13 & 1 & & 0.0 & & & & 0.0 & & & 0.0 & 1450 & & \\
\hline 3 & $20 \mathrm{~A}$ & 0.0 & 73.9 & 42.0 & 13 & 1 & & 0.0 & & & & 0.0 & & & 0.0 & 1300 & & \\
\hline 3 & 20B & 0.0 & 191.0 & 0.0 & 10 & 1 & & 0.0 & & & & 0.0 & & & 0.0 & 500 & & \\
\hline 3 & 21 & 0.0 & 60.2 & 18.0 & 71 & 1 & & 0.0 & & & & 0.0 & & & 0.0 & 2200 & & \\
\hline 3 & 22 & 0.0 & 38.2 & 6.4 & 10 & $i$ & & 0.0 & & & & 0.0 & & & 0.0 & & & \\
\hline 3 & 23 & 0.0 & 27.9 & 32.6 & 15 & 1 & & 0.0 & & & & 0.0 & & & 0.0 & & & \\
\hline 3 & $23 \mathrm{~A}$ & 0.0 & 135.6 & 22.6 & 10 & 1 & & 0.0 & & & & 0.0 & & & 0.0 & & & \\
\hline 3 & 24 & 0.0 & 62.7 & 22.0 & 13 & 1 & & 0.0 & & & & 0.0 & & & 0.0 & & & \\
\hline 3 & 25 & 0.0 & 37.9 & 2.9 & 15 & 1 & & 0.0 & & & & 0.0 & & & 0.0 & & & \\
\hline 3 & 26 & 0.0 & 85.3 & 62.5 & 71 & 1 & & 0.0 & & & & 0.0 & & & 0.0 & 2750 & & \\
\hline 3 & 27 & 0.0 & 67.4 & 30.0 & 71 & 1 & & 0.0 & & & & 0.0 & & & 0.0 & & 1 & \\
\hline 3 & 29 & 0.0 & 72.9 & 68.0 & 15 & 1 & & 0.0 & & & & 0.0 & & & 0.0 & & 1 & \\
\hline 3 & 30 & 85.9 & 50.0 & 4.3 & 1 & 1 & 3 & 2.0 & 1 & 4 & 3 & 2.5 & 5 & 1987 & 0.9 & 200 & 1 & \\
\hline 3 & 31 & 142.2 & 50.0 & 4.2 & 1 & 1 & 4 & 2.0 & 1 & 2 & 3 & 2.5 & 7 & 1988 & 1.4 & 200 & 1 & \\
\hline 3 & $32 A$ & 66.9 & 54.4 & 6.2 & 1 & 1 & 3 & 1.0 & 1 & 2 & 3 & 1.0 & 5 & 1975 & 1.0 & 300 & 1 & \\
\hline 3 & 33 & 62.3 & 38.8 & 1.7 & 1 & 1 & 3 & 1.0 & 1 & 2 & 3 & 1.0 & 5 & 1975 & 1.0 & 540 & & \\
\hline 3 & 34 & 0.0 & 78.7 & 73.0 & 33 & 1 & & 0.0 & & & & 0.0 & & & 0.0 & & 1 & \\
\hline 3 & 35 & 35.7 & 88.7 & 90.0 & 12 & 1 & 2 & 0.0 & & & & 0.0 & & 1965 & 1.5 & 2780 & & \\
\hline 3 & 36 & 0.0 & 66.8 & 34.7 & 13 & 1 & & 0.0 & & & & 0.0 & & & 0.0 & 300 & 1 & \\
\hline 3 & $36 \mathrm{~A}$ & 77.5 & 62.7 & 12.0 & 1 & 1 & 3 & 1.0 & 1 & 2 & 2 & 1.0 & 5 & 1975 & 1.2 & 630 & 1 & \\
\hline 3 & 36B & 85.8 & 61.1 & 10.9 & 1 & 1 & 4 & 1.0 & 1 & 2 & 2 & 1.5 & 6 & 1790 & 1.1 & 450 & & \\
\hline 3 & 37 & 71.2 & 60.1 & 10.0 & 1 & 1 & 3 & 1.0 & 1 & 4 & 2 & 1.0 & 5 & 1981 & 0.9 & 470 & 1 & \\
\hline 3 & 38 & 87.2 & 52.0 & 4.6 & 1 & 1 & 3 & 1.0 & 1 & 2 & 3 & 1.0 & 6 & 1987 & 0.9 & 800 & & \\
\hline 3 & $38 \mathrm{~A}$ & 106.5 & 52.0 & 4.6 & 1 & 1 & 3 & 1.0 & 1 & 2 & 4 & 1.5 & 7 & 1976 & 1.8 & 330 & & \\
\hline 3 & $38 B$ & 69.1 & 52.1 & 4.6 & 1 & 1 & 3 & 1.5 & 1 & 2 & 2 & 1.5 & 5 & 1978 & 0.8 & 420 & & \\
\hline 3 & $38 \mathrm{C}$ & 77.1 & 52.1 & 4.6 & 1 & 1 & 3 & 1.0 & 1 & 2 & 3 & 1.5 & 6 & 1977 & 1.2 & 360 & 1 & \\
\hline 3 & 39 & 0.0 & 70.5 & 35.7 & 13 & 1 & & 0.0 & & & & 0.0 & & & 0.0 & 656 & 1 & \\
\hline 3 & $39 \mathrm{~A}$ & 91.6 & 52.2 & 4.8 & 1 & 1 & 3 & 2.0 & 1 & 2 & 3 & 2.0 & 6 & 1988 & 1.0 & & & \\
\hline 3 & 40 & 92.5 & 53.1 & 5.3 & 1 & 1 & 3 & 1.0 & 1 & 2 & 2 & 2.0 & 5 & 1988 & 1.3 & 400 & & \\
\hline 3 & $40 \mathrm{~A}$ & 5.0 & 75.5 & 30.0 & 1 & 1 & & 0.0 & & & & 0.0 & & & 0.0 & 300 & & \\
\hline 3 & $40 \mathrm{~A} 1$ & 0.0 & 50.3 & 8.8 & 13 & $i$ & & 0.0 & & & & 0.0 & & & 0.0 & 300 & & \\
\hline 3 & $40 \mathrm{~A} 2$ & 33.3 & 52.6 & 5.0 & 1 & 1 & 3 & 2.0 & 1 & 2 & 2 & 2.0 & 6 & 1989 & 1.1 & 300 & & \\
\hline 3 & 40B & 165.4 & 62.0 & 11.5 & 1 & 1 & 5 & 2.0 & 1 & 2 & 2 & 2.5 & 8 & 1988 & 1.4 & 700 & 1 & \\
\hline 3 & $40 \mathrm{C}$ & 171.8 & 53.1 & 5.3 & 1 & i & 5 & 2.0 & 1 & 2 & 4 & 2.5 & 8 & 1988 & 1.6 & & & \\
\hline 3 & 42 & 0.0 & 60.6 & 20.0 & 13 & 1 & & 0.0 & & & & 0.0 & & & 0.0 & 429 & & \\
\hline 3 & 43 & 0.0 & 53.4 & 11.1 & 13 & 1 & & 0.0 & & & & 0.0 & & & 0.0 & 428 & & \\
\hline 3 & $43 \mathrm{~A}$ & 142.3 & 52.2 & 4.7 & 1 & 1 & 4 & 1.0 & 1 & 2 & 3 & 2.5 & 8 & 1988 & 2.2 & 395 & & \\
\hline 3 & $43 B$ & 0.0 & 44.0 & 4.6 & 13 & 1 & & 0.0 & & & & 0.0 & & & 0.0 & 427 & & \\
\hline 3 & 44 & 60.5 & 38.3 & 1.6 & 1 & 1 & 3 & 1.0 & 1 & 2 & 4 & 1.0 & 8 & 1950 & 1.2 & 200 & 1 & \\
\hline 3 & 45 & 0.0 & 32.2 & 1.5 & 13 & 1 & & 0.0 & & & & 0.0 & & & 0.0 & & 1 & \\
\hline
\end{tabular}




\begin{tabular}{|c|c|c|c|c|c|c|c|c|c|c|c|c|c|c|c|c|c|c|}
\hline Map & Lot & $\begin{array}{l}\text { Bldg. } \\
\text { Value }\end{array}$ & $\begin{array}{l}\text { Land } \\
\text { Value }\end{array}$ & Acres & $\begin{array}{l}\text { Land } \\
\text { Use }\end{array}$ & Zoning & $\begin{array}{l}\text { Bldg. } \\
\text { Grade }\end{array}$ & $\begin{array}{l}\text { \# of } \\
\text { Stories }\end{array}$ & $\begin{array}{l}\text { Occu- } \\
\text { pancy }\end{array}$ & $\begin{array}{l}\text { Heat } \\
\text { Type }\end{array}$ & $\begin{array}{l}\text { \# of } \\
\text { Beds }\end{array}$ & $\begin{array}{l}\text { \# of } \\
\text { Baths }\end{array}$ & $\begin{array}{l}\text { Total } \\
\text { Rooms }\end{array}$ & $\begin{array}{l}\text { Year } \\
\text { Built }\end{array}$ & $\begin{array}{l}1 \text { st } \\
\text { Floor }\end{array}$ & Frontage & $\begin{array}{l}\text { Wet- } \\
\text { lands }\end{array}$ & $\begin{array}{l}\text { Water- } \\
\text { shed }\end{array}$ \\
\hline 3 & 46 & 0.0 & 41.8 & 4.0 & 13 & 1 & & 0.0 & & & & 0.0 & & & 0.0 & 500 & 1 & \\
\hline 3 & $46 A$ & 0.0 & 40.3 & 3.7 & 13 & 1 & & 0.0 & & & & 0.0 & & & 0.0 & 400 & 1 & \\
\hline 3 & 47 & 64.7 & 41.1 & 2.3 & 1 & 1 & 3 & 1.0 & 1 & 2 & 3 & 2.0 & 6 & 1976 & 1.1 & 250 & & \\
\hline 3 & 48 & 0.0 & 31.8 & 27.2 & 13 & 1 & & 0.0 & & & & 0.0 & & & 0.0 & 300 & 1 & \\
\hline 3 & $48 \mathrm{~A}$ & 92.7 & 52.7 & 5.1 & 1 & 1 & 3 & 1.5 & 1 & 2 & 3 & 2.0 & 7 & 1987 & 1.1 & 800 & & \\
\hline 3 & 49 & 84.9 & 55.2 & 6.7 & 1 & 1 & 3 & 1.0 & 1 & 2 & 1 & 1.0 & 5 & 1960 & 1.6 & 600 & & \\
\hline 3 & 50 & 0.0 & 6.0 & 0.6 & 13 & 1 & & 0.0 & & & & 0.0 & & & 0.0 & & & \\
\hline 3 & 51 & 0.0 & 39.3 & 3.3 & 13 & 1 & & 0.0 & & & & 0.0 & & & 0.0 & 570 & & \\
\hline 3 & 52 & 100.3 & 53.7 & 7.8 & 1 & 1 & 3 & 2.0 & 1 & 2 & 3 & 2.0 & 7 & 1977 & 0.8 & 550 & & \\
\hline 3 & 53 & 52.1 & 61.2 & 8.0 & 1 & 1 & 3 & 1.5 & 1 & 2 & 3 & 1.0 & 6 & 1800 & 0.8 & & & \\
\hline 3 & 55 & 78.7 & 52.2 & 4.8 & 1 & 1 & 3 & 1.5 & 1 & 2 & 3 & 2.0 & 7 & 1954 & 1.0 & 200 & & \\
\hline 3 & 57 & 45.5 & 55.5 & 10.7 & 1 & 1 & 3 & 1.0 & 1 & 2 & 2 & 1.0 & 5 & 1945 & 0.9 & 423 & 1 & \\
\hline 3 & 58 & 0.0 & 66.4 & 37.7 & 13 & 1 & & 0.0 & & & & 0.0 & & & 0.0 & 3159 & 1 & \\
\hline 3 & 60 & 64.7 & 88.0 & 64.0 & 1 & 1 & 3 & 1.0 & 1 & 2 & 1 & 1.0 & 5 & 1945 & 1.1 & 750 & 1 & \\
\hline 3 & 61 & 0.0 & 54.7 & 12.0 & 13 & 1 & & 0.0 & & & & 0.0 & & & 0.0 & 848 & & \\
\hline 3 & 62 & 0.0 & 57.0 & 13.7 & 15 & 1 & & 0.0 & & & & 0.0 & & & 0.0 & & & \\
\hline 3 & 63 & 0.0 & 10.4 & 7.0 & 13 & 1 & & 0.0 & & & & 0.0 & & & 0.0 & & & \\
\hline 3 & 64 & 0.0 & 6.2 & 4.1 & 13 & 1 & & 0.0 & & & & 0.0 & & & 0.0 & & & \\
\hline 3 & 65 & 0.0 & 10.8 & 7.2 & 13 & 1 & & 0.0 & & & & 0.0 & & & 0.0 & & & \\
\hline 3 & 66 & 0.0 & 4.2 & 2.8 & 13 & 1 & & 0.0 & & & & 0.0 & & & 0.0 & & & \\
\hline 3 & 67 & 0.0 & 73.0 & 40.0 & 13 & 1 & & 0.0 & & & & 0.0 & & & 0.0 & & 1 & \\
\hline 4 & 1 & 84.0 & 52.6 & 5.0 & 1 & 1 & 3 & 1.0 & 1 & 2 & 3 & 1.0 & 5 & 1922 & 1.0 & 325 & & \\
\hline 4 & 2 & 67.5 & 67.7 & 17.3 & 1 & 1 & 3 & 1.0 & 1 & 2 & 3 & 1.0 & 5 & 1976 & 0.8 & 340 & 1 & \\
\hline 4 & $2 A$ & 67.3 & 52.1 & 4.6 & 1 & 1 & 3 & 1.0 & 1 & 2 & 2 & 1.0 & 3 & 1978 & 1.0 & 307 & & \\
\hline 4 & $3 \mathbf{A}$ & 93.7 & 57.1 & 8.0 & 1 & 1 & 4 & 2.0 & 1 & 2 & 3 & 1.5 & 6 & 1979 & 1.0 & 300 & & \\
\hline 4 & 4 & 0.0 & 37.9 & 3.0 & 13 & 1 & & 0.0 & & & & 0.0 & & & 0.0 & 420 & & \\
\hline 4 & 5 & 97.2 & 79.4 & 37.0 & 9 & 1 & 3 & 1.0 & 1 & 2 & 2 & 1.0 & 6 & 1920 & 1.3 & 1400 & & \\
\hline 4 & 6 & 75.0 & 54.1 & 6.0 & 1 & 1 & 3 & 1.5 & 1 & 2 & 3 & 1.5 & 8 & 1939 & 1.0 & 625 & & \\
\hline 4 & 7 & 77.4 & 47.3 & 3.5 & 1 & 1 & 3 & 1.5 & 1 & 2 & 4 & 1.5 & 7 & 1950 & 1.4 & 500 & & \\
\hline 4 & 8 & 81.2 & 53.8 & 5.8 & 1 & 1 & 3 & 1.5 & 1 & 2 & 3 & 1.0 & 6 & 1975 & 1.2 & 709 & & \\
\hline 4 & $8 A$ & 115.5 & 52.6 & 5.0 & 1 & 1 & 4 & 2.0 & 1 & 2 & 4 & 2.0 & 6 & 1973 & 1.1 & 500 & & \\
\hline 4 & $8 B$ & 93.2 & 52.6 & 5.0 & 80 & 1 & 3 & 1.0 & 1 & 2 & 3 & 2.0 & 6 & 1977 & 1.6 & 390 & & \\
\hline 4 & 9 & 97.9 & 59.4 & 9.6 & 1 & 1 & 3 & 1.0 & 1 & 2 & 3 & 1.0 & 6 & 1968 & 1.6 & 530 & & \\
\hline 4 & 10 & 80.5 & 53.1 & 5.3 & 1 & 1 & 3 & 2.0 & 1 & 2 & 3 & 1.5 & 7 & 1964 & 0.9 & 311 & & \\
\hline 4 & 11 & 64.6 & 43.4 & 2.7 & 1 & 1 & 3 & 1.0 & 1 & 2 & 3 & 1.0 & 5 & 1965 & 1.0 & 156 & & \\
\hline 4 & 12 & 67.6 & 43.7 & 2.7 & 1 & 1 & 3 & 1.0 & 1 & 4 & 3 & 1.5 & 5 & 1965 & 1.3 & 156 & & \\
\hline 4 & 13 & 97.4 & 52.6 & 5.0 & 1 & 1 & 4 & 1.5 & 1 & 2 & 3 & 1.5 & 6 & 1965 & 0.9 & 290 & & \\
\hline 4 & 14 & 69.6 & 52.7 & 5.0 & 1 & 1 & 3 & 2.0 & 1 & 4 & 3 & 1.5 & 6 & 1974 & 0.8 & 300 & & \\
\hline 4 & $14 \mathrm{~A}$ & 75.1 & 52.9 & 5.2 & 1 & 1 & 3 & 1.0 & 1 & 2 & 3 & 1.0 & 4 & 1973 & 1.3 & 369 & & \\
\hline 4 & $14 C$ & 109.0 & 53.5 & 5.6 & 1 & 1 & 4 & 1.5 & 1 & 2 & 3 & 2.0 & 6 & 1973 & 1.1 & 300 & & \\
\hline
\end{tabular}




\begin{tabular}{|c|c|c|c|c|c|c|c|c|c|c|c|c|c|c|c|c|c|c|}
\hline Map & Lot & $\begin{array}{l}\text { Bldg. } \\
\text { Value }\end{array}$ & $\begin{array}{l}\text { Land } \\
\text { Value }\end{array}$ & Acres & $\begin{array}{l}\text { Land } \\
\text { Use }\end{array}$ & Zoning & $\begin{array}{l}\text { Bldg. } \\
\text { Grade }\end{array}$ & $\begin{array}{l}\text { \# of } \\
\text { Stories }\end{array}$ & $\begin{array}{l}\text { Occu- } \\
\text { pancy }\end{array}$ & $\begin{array}{l}\text { Heat } \\
\text { Type }\end{array}$ & $\begin{array}{l}\text { "of } \\
\text { Beds }\end{array}$ & $\begin{array}{l}\text { \# of } \\
\text { Baths }\end{array}$ & $\begin{array}{l}\text { Total } \\
\text { Rooms }\end{array}$ & $\begin{array}{l}\text { Year } \\
\text { Built }\end{array}$ & $\begin{array}{l}\text { 1st } \\
\text { Floor }\end{array}$ & Frontage & $\begin{array}{l}\text { Wet- } \\
\text { lands }\end{array}$ & $\begin{array}{l}\text { Water- } \\
\text { shed }\end{array}$ \\
\hline 4 & 15 & 15.6 & 36.6 & 1.0 & 12 & 1 & 1 & 1.0 & 0 & 1 & 0 & 0.0 & 7 & 1960 & 1.2 & 208 & & \\
\hline 4 & 16 & 0.0 & 50.6 & 9.0 & 13 & 1 & & 0.0 & & & & 0.0 & & & 0.0 & 450 & & \\
\hline 4 & 17 & 45.4 & 55.6 & 7.0 & 1 & 1 & 2 & 1.5 & 1 & 2 & 2 & 1.0 & 6 & 1749 & 1.1 & 750 & & \\
\hline 4 & 18 & 46.9 & 54.1 & 6.0 & 1 & 1 & 3 & 1.0 & 1 & 2 & 1 & 1.0 & 3 & 1945 & 0.7 & 780 & & \\
\hline 4 & $18 \mathrm{~A}$ & 0.0 & 49.1 & 8.0 & 13 & 1 & & 0.0 & & & & 0.0 & & & 0.0 & & & \\
\hline 4 & 19 & 109.6 & 71.9 & 24.0 & 1 & 1 & 4 & 1.5 & 1 & 2 & 4 & 2.0 & 6 & 1980 & 1.0 & 700 & & \\
\hline 4 & $19 \mathrm{~A}$ & 52.8 & 53.5 & 5.6 & 1 & 1 & 3 & 1.0 & 1 & 4 & 1 & 1.0 & 4 & 1984 & 0.8 & 350 & & \\
\hline 4 & 20 & 35.6 & 96.7 & 70.0 & 1 & 1 & 2 & 1.0 & 1 & 2 & 2 & 1.0 & 4 & 1914 & 0.7 & 1000 & 1 & \\
\hline 4 & 21 & 58.5 & 104.8 & 125.0 & 1 & 1 & 3 & 1.0 & 1 & 2 & 2 & 1.0 & 5 & 1800 & 1.1 & 1300 & 1 & \\
\hline 4 & 23 & 0.0 & 25.6 & 38.0 & 13 & 1 & & 0.0 & & & & 0.0 & & & 0.0 & & 1 & \\
\hline 4 & $23 \mathrm{~A}$ & 0.0 & 15.0 & 10.0 & 15 & 1 & & 0.0 & & & & 0.0 & & & 0.0 & & & \\
\hline 4 & $23 B$ & 0.0 & 12.0 & 8.0 & 15 & 1 & & 0.0 & & & & 0.0 & & & 0.0 & & & \\
\hline 4 & 24 & 75.8 & 79.9 & 52.0 & 1 & 1 & 4 & 1.0 & 1 & 2 & 3 & 1.0 & 8 & 1800 & 1.1 & 650 & 1 & \\
\hline 4 & 25 & 0.0 & 52.0 & 15.0 & 33 & 1 & & 0.0 & & & & 0.0 & & & 0.0 & 820 & & \\
\hline 4 & 26 & 60.1 & 40.1 & 2.0 & 1 & 1 & 3 & 1.0 & 1 & 4 & 3 & 1.0 & 5 & 1949 & 1.5 & 210 & & \\
\hline 4 & 27 & 68.2 & 54.2 & 6.8 & 1 & 1 & 3 & 1.0 & 1 & 2 & 3 & 1.5 & 5 & 1978 & 1.4 & 30 & & \\
\hline 4 & 28 & 70.2 & 36.6 & 1.0 & 1 & 1 & 3 & 1.0 & 1 & 2 & 4 & 2.0 & 6 & 1965 & 1.3 & 170 & & \\
\hline 4 & 29 & 93.7 & 52.1 & 4.6 & 1 & 1 & 3 & 1.5 & 1 & 2 & 3 & 2.0 & 7 & 1967 & 1.2 & 325 & & \\
\hline 4 & 30 & 116.5 & 96.7 & 70.0 & 9 & 1 & 3 & 1.0 & 1 & 2 & 3 & 1.5 & 6 & 1780 & 1.2 & 910 & & \\
\hline 4 & 31 & 55.8 & 70.8 & 22.0 & 1 & 1 & 3 & 1.5 & 1 & 2 & 3 & 1.0 & 5 & 1935 & 0.8 & 390 & & \\
\hline 4 & 32 & 91.9 & 109.2 & 95.0 & 1 & 1 & 3 & 1.0 & 1 & 2 & 2 & 1.5 & 5 & 1865 & 1.3 & 900 & 1 & \\
\hline 4 & 33 & 56.1 & 52.2 & 4.8 & 1 & 1 & 2 & 1.0 & 1 & 3 & 2 & 1.0 & 4 & 1962 & 0.8 & 212 & & \\
\hline 4 & 34 & 56.9 & 30.3 & 0.5 & 1 & 1 & 3 & 1.0 & 1 & 2 & 3 & 1.0 & 5 & 1964 & 0.9 & 100 & & \\
\hline 4 & 35 & 93.6 & 66.6 & 15.0 & 9 & 1 & 3 & 1.0 & 1 & 2 & 3 & 1.0 & 5 & 1920 & 0.9 & 482 & & \\
\hline 4 & 36 & 42.0 & 52.6 & 5.0 & 1 & 1 & 3 & 1.0 & 1 & 2 & 2 & 1.0 & 4 & 1959 & 0.8 & 372 & & \\
\hline 4 & 37 & 118.8 & 86.1 & 54.7 & 1 & 1 & 3 & 1.5 & 1 & 2 & 4 & 2.0 & 8 & 1972 & 1.1 & 431 & & \\
\hline 4 & 38 & 90.4 & 52.6 & 5.0 & 1 & 1 & 3 & 1.0 & 1 & 2 & 3 & 1.0 & 7 & 1829 & 1.1 & 263 & & \\
\hline 4 & 40 & 57.9 & 67.0 & 16.0 & 1 & 1 & 3 & 1.0 & 1 & 2 & 3 & 1.0 & 5 & 1940 & 1.3 & 660 & & \\
\hline 4 & 41 & 0.0 & 92.2 & 78.0 & 15 & 1 & & 0.0 & & & & 0.0 & & & 0.0 & & 1 & \\
\hline 4 & 42 & 1.1 & 66.0 & 24.0 & 1 & 1 & 1 & 1.0 & 0 & 1 & 1 & 1.0 & 2 & 1952 & 0.2 & 300 & & \\
\hline 4 & 43 & 60.9 & 36.0 & 1.0 & 1 & 1 & 3 & 1.0 & 1 & 2 & 3 & 1.0 & 5 & 1946 & 1.3 & 200 & & \\
\hline 4 & 44 & 15.6 & 35.3 & 0.9 & 1 & 1 & 3 & 1.0 & 1 & 1 & 2 & 1.0 & 4 & 1971 & 1.0 & 200 & & \\
\hline 4 & 45 & 90.2 & 33.1 & 0.7 & 1 & 1 & 3 & 1.0 & 1 & 2 & 3 & 2.0 & 7 & 1963 & 1.3 & 165 & & \\
\hline 4 & 46 & 0.0 & 60.5 & 18.5 & 13 & 1 & & 0.0 & & & & 0.0 & & & 0.0 & 414 & & \\
\hline 4 & 47 & 64.5 & 39.0 & 1.7 & 1 & 1 & 3 & 1.0 & 1 & 3 & 2 & 1.0 & 6 & 1910 & 1.5 & 216 & & \\
\hline 4 & 48 & 61.0 & 52.1 & 4.6 & 1 & 1 & 3 & 2.0 & 1 & 2 & 4 & 1.0 & 6 & 1935 & 0.8 & 50 & & \\
\hline 4 & 49 & 42.0 & 25.0 & 0.4 & 1 & 1 & 2 & 1.0 & 1 & 2 & 2 & 1.0 & 4 & 1940 & 0.8 & 150 & & \\
\hline 4 & 50 & 111.8 & 69.5 & 20.0 & 1 & 1 & 3 & 1.0 & 1 & 2 & 3 & 2.0 & 6 & 1959 & 2.3 & 231 & & \\
\hline 4 & 51 & 73.7 & 54.1 & 6.0 & 1 & 1 & 3 & 1.0 & 1 & 2 & 3 & 1.0 & 7 & 1956 & 1.5 & 685 & & \\
\hline 4 & 52 & 41.5 & 37.6 & 1.3 & 1 & 1 & 2 & 1.5 & 1 & 2 & 2 & 1.0 & 5 & 1943 & 0.7 & 245 & & \\
\hline
\end{tabular}




\begin{tabular}{|c|c|c|c|c|c|c|c|c|c|c|c|c|c|c|c|c|}
\hline Map & Lot & $\begin{array}{l}\text { Bldg. } \\
\text { Value }\end{array}$ & $\begin{array}{l}\text { Land } \\
\text { Value }\end{array}$ & Acres & $\begin{array}{l}\text { Land } \\
\text { Use }\end{array}$ & Zoning & $\begin{array}{l}\text { Bldg. } \\
\text { Grade }\end{array}$ & $\begin{array}{l}\text { \# of } \\
\text { Stories }\end{array}$ & $\begin{array}{l}\text { Occu- } \\
\text { pancy }\end{array}$ & $\begin{array}{l}\text { Heat } \\
\text { Type }\end{array}$ & $\begin{array}{l}\text { \# of } \\
\text { Beds }\end{array}$ & $\begin{array}{l}\text { \# of } \\
\text { Baths }\end{array}$ & $\begin{array}{l}\text { Total } \\
\text { Rooms }\end{array}$ & $\begin{array}{l}\text { Year } \\
\text { Built }\end{array}$ & $\begin{array}{l}\text { 1st } \\
\text { Floor }\end{array}$ & Frontage \\
\hline 4 & 53 & 60.8 & 33.7 & 0.8 & 1 & 1 & 3 & 1.5 & 1 & 2 & 2 & 1.0 & 5 & 1939 & 0.8 & 135 \\
\hline 4 & 54 & 94.0 & 54.9 & 6.5 & 1 & 1 & 3 & 1.0 & 1 & 3 & 4 & 2.0 & 6 & 1915 & 1.3 & 800 \\
\hline 4 & 54 & 0.0 & 0.0 & 0.0 & 1 & 1 & 2 & 1.0 & 1 & 1 & 1 & 1.0 & 2 & 1919 & 0.9 & \\
\hline 4 & $54 \mathrm{~A}$ & 84.4 & 95.0 & 40.0 & 9 & 1 & & 0.0 & & & & 0.0 & & & 0.0 & 900 \\
\hline 4 & 54B & 0.0 & 44.1 & 4.6 & 13 & 1 & & 0.0 & & & & 0.0 & & & 0.0 & \\
\hline 4 & $54 \mathrm{C}$ & 0.0 & 44.1 & 4.6 & 13 & 1 & & 0.0 & & & & 0.0 & & & 0.0 & \\
\hline 4 & 54D & 0.0 & 44.0 & 4.6 & 13 & 1 & & 0.0 & & & & 0.0 & & & 0.0 & \\
\hline 4 & 55 & 0.0 & 11.8 & 11.5 & 13 & 1 & & 0.0 & & & & 0.0 & & & 0.0 & \\
\hline 4 & 56 & 0.0 & 26.0 & 39.0 & 13 & 1 & & 0.0 & & & & 0.0 & & & 0.0 & \\
\hline 4 & 57 & 0.0 & 57.4 & 38.0 & 15 & 1 & & 0.0 & & & & 0.0 & & & 0.0 & 1800 \\
\hline 4 & 58 & 72.2 & 98.6 & 180.0 & 1 & 1 & 3 & 1.5 & 1 & 2 & 2 & 1.0 & 6 & 1950 & 0.9 & 1950 \\
\hline 4 & 59 & 83.3 & 72.0 & 32.0 & 1 & 1 & 4 & 1.5 & 1 & 4 & 3 & 1.0 & 5 & 1983 & 0.9 & 750 \\
\hline 4 & $59 \mathrm{~A}$ & 98.5 & 72.0 & 32.0 & i & 1 & 4 & 2.0 & 1 & 4 & 3 & 1.0 & 6 & 1983 & 1.0 & 750 \\
\hline 4 & 61 & 57.6 & 61.2 & 15.0 & $i$ & 1 & 3 & 1.0 & $i$ & 4 & 2 & 1.0 & 6 & 1960 & 0.9 & 1300 \\
\hline 4 & 62 & 0.0 & 67.6 & 39.0 & 13 & 1 & & 0.0 & & & & 0.0 & & & 0.0 & 2000 \\
\hline 4 & 63 & 72.5 & 75.2 & 43.4 & 1 & 1 & 4 & 1.5 & 1 & 2 & 3 & 1.0 & 6 & 1820 & 0.6 & 3400 \\
\hline 4 & $63 \mathrm{~A}$ & 84.3 & 44.2 & 4.7 & 1 & 1 & 3 & 1.0 & 1 & 2 & 3 & 1.5 & 5 & 1988 & 1.3 & \\
\hline 4 & $63 B$ & 0.0 & 44.7 & 5.0 & 13 & 1 & & 0.0 & & & & 0.0 & & & 0.0 & \\
\hline 4 & $63 \mathrm{C}$ & 0.0 & 53.2 & 11.0 & 13 & 1 & & 0.0 & & & & 0.0 & & & 0.0 & \\
\hline 4 & 64 & 69.0 & 52.8 & 5.1 & 1 & $i$ & 3 & 1.0 & 1 & 2 & 3 & 1.0 & 6 & 1820 & 1.1 & 700 \\
\hline 4 & $64 \mathrm{~A}$ & 0.0 & 49.7 & 8.1 & 13 & 1 & & 0.0 & & & & 0.0 & & & 0.0 & \\
\hline 4 & 65 & 25.7 & 63.4 & 12.6 & 1 & i & 3 & 1.0 & 1 & 3 & 2 & 1.0 & 6 & 1962 & 1.3 & 534 \\
\hline 4 & 66 & 0.0 & 55.6 & 12.7 & 13 & 1 & & 0.0 & & & & 0.0 & & & 0.0 & 26 \\
\hline 4 & 67 & 39.6 & 65.4 & 14.0 & 1 & 1 & 2 & 1.0 & 1 & 3 & 2 & 1.0 & 5 & 1947 & 0.7 & 358 \\
\hline 4 & 68 & 0.0 & 68.0 & 36.5 & 13 & $i$ & & 0.0 & & & & 0.0 & & & 0.0 & 1584 \\
\hline 4 & 70 & 69.2 & 45.6 & 3.4 & 1 & 1 & 3 & 1.0 & 1 & 2 & 2 & 1.0 & 5 & 1976 & 1.0 & 350 \\
\hline 4 & 71 & 94.8 & 42.5 & 2.5 & 1 & 1 & 3 & 1.5 & 1 & 2 & 3 & 2.0 & 7 & 1964 & 1.3 & 300 \\
\hline 4 & 72 & 51.6 & 0.0 & 0.0 & 1 & 1 & 2 & 1.0 & 1 & 2 & 2 & 1.5 & 4 & 1880 & 1.0 & \\
\hline 4 & 72 & 105.4 & 84.3 & 50.0 & 2 & 1 & 4 & 2.0 & 3 & 2 & 5 & 3.0 & 12 & 1858 & 1.4 & 1800 \\
\hline 4 & 73 & 106.3 & 52.2 & 4.7 & 1 & 1 & 4 & 1.0 & 1 & 2 & 3 & 2.5 & 5 & 1989 & 1.3 & 721 \\
\hline 4 & 74 & 88.7 & 52.8 & 5.1 & $i$ & 1 & 3 & 1.0 & $i$ & 2 & 2 & 1.0 & 5 & 1986 & 1.0 & 736 \\
\hline 4 & $74 \mathrm{~A}$ & 82.6 & 52.5 & 5.7 & 1 & 1 & 4 & 2.0 & i & 2 & 2 & 1.5 & 3 & 1987 & 0.6 & 776 \\
\hline 4 & 75 & 0.0 & 0.0 & 0.0 & 11 & 1 & 2 & 1.0 & 1 & 1 & & 0.0 & & 1955 & 2.2 & \\
\hline 4 & 75 & 0.0 & 0.0 & 0.0 & 11 & 1 & 1 & 0.0 & i & i & & 0.0 & & 1955 & 0.7 & \\
\hline 4 & 75 & 488.8 & 136.5 & 115.0 & 11 & 1 & 2 & 0.0 & 1 & 1 & & 0.0 & & 1955 & 0.4 & 2650 \\
\hline 4 & 76 & 0.0 & 63.1 & 12.0 & 6 & 1 & & 0.0 & & & & 0.0 & & & 0.0 & 2000 \\
\hline 4 & 77 & 88.6 & 37.4 & 1.3 & 1 & 1 & 3 & 1.0 & 1 & 2 & 3 & 1.0 & 6 & 1959 & 1.9 & 118 \\
\hline 4 & 78 & 127.0 & 67.6 & 19.5 & $i$ & 1 & 4 & 2.0 & 1 & 2 & 3 & 2.5 & 7 & 1984 & 1.1 & 616 \\
\hline 4 & $78 \mathrm{~A}$ & 0.0 & 52.2 & 13.7 & 13 & 1 & & 0.0 & & & & 0.0 & & & 0.0 & 325 \\
\hline 4 & 79 & 3.4 & 44.6 & 5.0 & 11 & 1 & & 0.0 & & & & 0.0 & & & 0.0 & 500 \\
\hline
\end{tabular}




\begin{tabular}{|c|c|c|c|c|c|c|c|c|c|c|c|c|c|c|c|c|c|c|}
\hline Map & Lot & $\begin{array}{l}\text { Bldg. } \\
\text { Value }\end{array}$ & $\begin{array}{l}\text { Land } \\
\text { Value }\end{array}$ & Acres & $\begin{array}{l}\text { Land } \\
\text { Use }\end{array}$ & Zoning & $\begin{array}{l}\text { Bldg. } \\
\text { Grade }\end{array}$ & $\begin{array}{l}\text { \# of } \\
\text { Stories }\end{array}$ & $\begin{array}{l}\text { Occu- } \\
\text { pancy }\end{array}$ & $\begin{array}{l}\text { Heat } \\
\text { Type }\end{array}$ & $\begin{array}{l}\text { \# of } \\
\text { Beds }\end{array}$ & $\begin{array}{l}\text { \# of } \\
\text { Baths }\end{array}$ & $\begin{array}{l}\text { Total } \\
\text { Rooms }\end{array}$ & $\begin{array}{l}\text { Year } \\
\text { Built }\end{array}$ & $\begin{array}{l}\text { 1st } \\
\text { Floor }\end{array}$ & Frontage & $\begin{array}{l}\text { Wet- } \\
\text { lands }\end{array}$ & $\begin{array}{l}\text { Water- } \\
\text { shed }\end{array}$ \\
\hline 4 & 80 & 80.3 & 51.0 & 4.5 & 1 & 1 & 3 & 1.5 & 1 & 2 & 3 & 2.0 & 5 & 1979 & 0.9 & & & \\
\hline 4 & 81 & 13.4 & 63.6 & 25.0 & 13 & 1 & & 0.0 & & & & 0.0 & & & 0.0 & 50 & 1 & \\
\hline 4 & 83 & 0.0 & 92.1 & 48.0 & 6 & 1 & & 0.0 & & & & 0.0 & & & 0.0 & 2250 & 1 & \\
\hline 4 & 84 & 109.1 & 55.5 & 6.9 & 1 & 1 & 4 & 2.0 & 1 & 2 & 2 & 2.5 & 5 & 1980 & 0.8 & 973 & 1 & \\
\hline 4 & 87 & 25.3 & 64.7 & 28.8 & 33 & 1 & & 0.0 & & & & 0.0 & & & 0.0 & 1900 & 1 & \\
\hline 5 & 1 & 126.1 & 69.0 & 24.0 & 1 & 1 & 3 & 1.0 & 1 & 2 & 4 & 2.0 & 12 & 1964 & 2.2 & 1000 & 1 & \\
\hline 5 & 2 & 0.0 & 0.0 & 0.0 & 11 & 1 & 1 & 1.0 & 1 & 3 & 2 & 0.0 & 4 & 1975 & 0.3 & & & \\
\hline 5 & 2 & 0.0 & 0.0 & 0.0 & 11 & 1 & 3 & 1.0 & 1 & 3 & 2 & 1.0 & 5 & 1976 & 0.7 & & & \\
\hline 5 & 2 & 0.0 & 0.0 & 0.0 & 11 & 1 & 1 & 1.0 & 1 & 1 & 1 & 0.0 & 4 & 1965 & 0.3 & & & \\
\hline 5 & 2 & 0.0 & 0.0 & 0.0 & 11 & 1 & 3 & 1.0 & 1 & 3 & 2 & 1.0 & 5 & 1982 & 0.8 & & & \\
\hline 5 & 2 & 0.0 & 0.0 & 0.0 & 11 & 1 & 3 & 1.0 & 1 & 3 & 2 & 1.0 & 4 & 1972 & 0.8 & & & \\
\hline 5 & 2 & 0.0 & 0.0 & 0.0 & 11 & 1 & 1 & 1.0 & 1 & 1 & & 0.0 & & 1984 & 0.3 & & & \\
\hline 5 & 2 & 416.1 & 160.7 & 200.0 & 11 & 1 & 3 & 1.0 & 1 & 1 & 2 & 1.0 & 5 & 1850 & 0.8 & 2360 & 1 & \\
\hline 5 & 2 & 0.0 & 0.0 & 0.0 & 11 & 1 & 1 & 1.0 & 1 & 4 & 1 & 4.0 & 5 & 1975 & 0.2 & & & \\
\hline 5 & 2 & 0.0 & 0.0 & 0.0 & 11 & 1 & 2 & 1.0 & 1 & 1 & & 0.0 & & 1970 & 0.6 & & & \\
\hline 5 & 2 & 0.0 & 0.0 & 0.0 & 11 & 1 & 1 & 2.0 & 1 & 3 & 1 & 1.0 & 5 & 1968 & 0.5 & & & \\
\hline 5 & 2 & 0.0 & 0.0 & 0.0 & 11 & 1 & 3 & 1.0 & 1 & 3 & 2 & 1.0 & 4 & 1974 & 0.2 & & & \\
\hline 5 & 2 & 0.0 & 0.0 & 0.0 & 11 & 1 & 1 & 1.0 & 1 & 1 & 1 & 0.0 & 4 & 1974 & 0.2 & & & \\
\hline 5 & 2 & 0.0 & 0.0 & 0.0 & 11 & 1 & 3 & 1.0 & 1 & 1 & & 0.0 & & 1987 & 1.5 & & & \\
\hline 5 & 2 & 0.0 & 0.0 & 0.0 & 11 & 1 & 1 & 1.0 & 1 & 1 & 1 & 0.0 & 4 & 1965 & 0.2 & & & \\
\hline 5 & 2 & 0.0 & 0.0 & 0.0 & 11 & 1 & 1 & 1.0 & 1 & 1 & 1 & 0.0 & 3 & 1965 & 0.5 & & & \\
\hline 5 & 2 & 0.0 & 0.0 & 0.0 & 11 & 1 & 3 & 1.0 & 1 & 3 & 1 & 0.0 & 3 & 1973 & 0.4 & & & \\
\hline 5 & 2 & 0.0 & 0.0 & 0.0 & 11 & 1 & 1 & 1.0 & 1 & 3 & & 0.0 & & 1970 & 0.4 & & & \\
\hline 5 & 2 & 0.0 & 0.0 & 0.0 & 11 & 1 & 3 & 1.0 & 1 & 3 & 2 & 1.0 & 4 & 1978 & 0.4 & & & \\
\hline 5 & 2 & 0.0 & 0.0 & 0.0 & 11 & 1 & 2 & 1.0 & 1 & 3 & 1 & 1.0 & 4 & 1970 & 0.5 & & & \\
\hline 5 & 3 & 26.9 & 43.1 & 2.8 & 1 & 1 & 2 & 1.0 & 1 & 2 & 2 & 1.0 & 4 & 1920 & 0.5 & 350 & & \\
\hline 5 & 4 & 0.0 & 50.6 & 9.0 & 13 & 1 & & 0.0 & & & & 0.0 & & & 0.0 & 300 & & \\
\hline 5 & 5 & 0.0 & 19.0 & 17.5 & 13 & 1 & & 0.0 & & & & 0.0 & & & 0.0 & & 1 & \\
\hline 5 & 6 & 0.0 & 16.1 & 12.5 & 13 & 1 & & 0.0 & & & & 0.0 & & & 0.0 & & 1 & \\
\hline 5 & 7 & 104.4 & 40.3 & 2.0 & 1 & 1 & 3 & 1.0 & 1 & 2 & 3 & 2.5 & 6 & 1964 & 1.8 & 213 & & \\
\hline 5 & 8 & 0.0 & 0.0 & 0.0 & 6 & 1 & 3 & 0.0 & & 2 & & 0.0 & & 1950 & 1.1 & & & \\
\hline 5 & 8 & 1331.8 & 117.4 & 81.6 & 6 & 1 & 3 & 0.0 & & 2 & & 0.0 & & 1975 & 5.9 & 2700 & 1 & \\
\hline 5 & 9 & 0.0 & 109.0 & 110.0 & 13 & $i$ & & 0.0 & & & & 0.0 & & & 0.0 & 1550 & 1 & \\
\hline 5 & $9 \mathrm{~B}$ & 8.6 & 73.1 & 40.1 & 13 & 1 & & 0.0 & & & & 0.0 & & & 0.0 & 700 & 1 & \\
\hline 5 & 10 & 84.2 & 54.9 & 6.5 & 1 & 1 & 3 & 1.0 & 1 & 2 & 3 & 1.0 & 5 & 1988 & 1.1 & 360 & & \\
\hline 5 & 11 & 62.5 & 54.9 & 6.5 & 1 & 1 & 3 & 1.0 & 1 & 2 & 2 & 1.0 & 2 & 1988 & 0.8 & 452 & & \\
\hline 5 & 12 & 87.7 & 42.5 & 2.5 & 1 & 1 & 3 & 1.0 & 1 & 2 & 3 & 2.0 & 5 & 1988 & 1.2 & 148 & & \\
\hline 5 & 13 & 0.0 & 8.5 & 3.3 & 13 & 1 & & 0.0 & & & & 0.0 & & & 0.0 & & & \\
\hline 5 & 14 & 13.8 & 54.1 & 6.0 & 1 & 1 & 1 & 1.0 & & 1 & 2 & 0.0 & 1 & 1965 & 0.4 & & & \\
\hline 5 & 15 & 0.0 & 43.1 & 4.5 & 13 & $i$ & & 0.0 & & & & 0.0 & & & 0.0 & & & \\
\hline
\end{tabular}




\begin{tabular}{|c|c|c|c|c|c|c|c|c|c|c|c|c|c|c|c|c|c|c|}
\hline Map & Lot & $\begin{array}{l}\text { Bldg. } \\
\text { Value }\end{array}$ & $\begin{array}{l}\text { Land } \\
\text { Value }\end{array}$ & Acres & $\begin{array}{l}\text { Land } \\
\text { Use }\end{array}$ & Zoning & $\begin{array}{l}\text { Bldg. } \\
\text { Grade }\end{array}$ & $\begin{array}{l}\text { \# of } \\
\text { Stories }\end{array}$ & $\begin{array}{l}\text { Occu- } \\
\text { pancy }\end{array}$ & $\begin{array}{l}\text { Heat } \\
\text { Type }\end{array}$ & $\begin{array}{l}\text { of } \\
\text { Beds }\end{array}$ & $\begin{array}{l}\text { of } \\
\text { Baths }\end{array}$ & $\begin{array}{l}\text { Total } \\
\text { Rooms }\end{array}$ & $\begin{array}{l}\text { Year } \\
\text { Built }\end{array}$ & $\begin{array}{l}\text { 1st } \\
\text { Floor }\end{array}$ & Frontage & $\begin{array}{l}\text { Wet- } \\
\text { lands }\end{array}$ & $\begin{array}{l}\text { Water- } \\
\text { shed }\end{array}$ \\
\hline 5 & 16 & 22.0 & 69.3 & 19.5 & 1 & 1 & 1 & 1.0 & & 1 & 1 & 1.0 & 2 & 1965 & 0.5 & & & \\
\hline 5 & 16 & 0.0 & 0.0 & 0.0 & 1 & 1 & $i$ & 1.0 & & 1 & 1 & 1.0 & 1 & 1940 & 0.3 & & & \\
\hline 5 & 17 & 5.1 & 60.4 & 18.4 & 12 & $i$ & & 0.0 & & & & 0.0 & & & 0.0 & & & \\
\hline 5 & 18 & 57.5 & 54.1 & 6.0 & 1 & 1 & 3 & 1.0 & 1 & 2 & 3 & 1.0 & 5 & 1973 & 1.0 & 625 & & \\
\hline 5 & 19 & 63.0 & 49.4 & 4.2 & 1 & $i$ & 3 & 1.0 & 1 & 2 & 3 & 1.5 & 6 & 1960 & 1.3 & 200 & & \\
\hline 5 & 20 & 63.4 & 55.6 & 7.0 & 1 & 1 & 3 & 1.0 & 1 & 2 & 3 & 1.0 & 5 & 1972 & 1.0 & 545 & & \\
\hline 5 & 21 & 74.1 & 62.0 & 11.5 & 1 & 1 & 3 & 2.0 & 1 & 1 & 4 & 1.0 & 6 & 1971 & 0.8 & 320 & & \\
\hline 5 & 22 & 107.3 & 82.3 & 47.4 & 1 & 1 & 4 & 1.0 & $i$ & 4 & 2 & 2.0 & 6 & 1820 & 1.5 & 850 & 1 & \\
\hline 5 & $22 \mathrm{~A}$ & 80.1 & 52.7 & 5.1 & 1 & 1 & 3 & 1.0 & 1 & i & 2 & 1.0 & 6 & 1973 & 1.0 & 300 & & \\
\hline 5 & 23 & 101.4 & 36.7 & 1.1 & 1 & 1 & 3 & 1.5 & 1 & 2 & 4 & 2.0 & 7 & 1973 & 1.0 & 132 & & \\
\hline 5 & 24 & 0.0 & 112.0 & 126.0 & 13 & $i$ & & 0.0 & & & & 0.0 & & & 0.0 & 245 & 1 & \\
\hline 5 & 25 & 79.2 & 67.0 & 17.0 & 1 & 1 & 4 & 1.0 & 1 & 2 & 4 & 1.0 & 8 & 1771 & 1.1 & 1050 & & \\
\hline 5 & 26 & 10.7 & 36.6 & 1.0 & $i$ & 1 & 3 & 1.0 & 1 & 2 & 2 & 1.0 & 4 & 1967 & 0.6 & 106 & & \\
\hline 5 & 27 & 0.0 & 86.7 & 74.0 & 13 & 1 & & 0.0 & & & & 0.0 & & & 0.0 & 3000 & 1 & \\
\hline 5 & $27 \mathrm{~A}$ & 0.0 & 54.1 & 6.0 & 11 & 1 & & 0.0 & & & & 0.0 & & & 0.0 & 200 & & \\
\hline 5 & 28 & 62.2 & 60.5 & 10.5 & 1 & 1 & 3 & 1.0 & 1 & 2 & 4 & 1.0 & 8 & 1936 & 1.3 & 450 & & \\
\hline 5 & 29 & 45.9 & 33.2 & 0.8 & $i$ & $i$ & 2 & 1.0 & $i$ & 2 & 1 & 1.0 & 5 & 1958 & 0.9 & 250 & & \\
\hline 5 & 30 & 75.3 & 58.2 & 8.8 & 1 & 1 & 3 & 1.5 & 1 & 2 & 4 & 1.5 & 7 & 1972 & 0.9 & 750 & & \\
\hline 5 & 31 & 69.6 & 38.9 & 1.8 & 1 & i & 3 & 1.0 & 1 & 4 & 4 & 1.0 & 6 & 1966 & 1.2 & 271 & & \\
\hline 5 & 32 & 55.8 & 52.2 & 4.8 & 1 & 1 & 3 & 1.0 & 1 & 2 & 2 & 2.0 & 5 & 1983 & 0.8 & 355 & & \\
\hline 5 & 33 & 63.4 & 55.6 & 7.0 & $i$ & $i$ & 3 & 1.0 & 1 & 2 & 3 & 1.0 & 5 & 1969 & 1.0 & 272 & 1 & \\
\hline 5 & 34 & 8.5 & 51.4 & 9.5 & 13 & 1 & & 0.0 & & & & 0.0 & & & 0.0 & 850 & 1 & \\
\hline 5 & 35 & 48.8 & 41.2 & 2.2 & 1 & $i$ & 3 & 1.0 & 1 & 2 & 2 & 1.0 & 5 & 1910 & 0.7 & 419 & & \\
\hline 5 & 36 & 0.0 & 61.3 & 26.0 & 13 & 1 & & 0.0 & & & & 0.0 & & & 0.0 & 468 & 1 & \\
\hline 5 & 37 & 116.6 & 67.6 & 16.9 & 1 & 1 & 4 & 2.0 & 1 & 2 & 3 & 2.0 & 6 & 1970 & 0.9 & 900 & 1 & \\
\hline 5 & 39 & 83.1 & 67.7 & 17.0 & $i$ & $i$ & 3 & 1.0 & 1 & 2 & 2 & 2.0 & 8 & 1978 & 1.1 & 312 & & \\
\hline 5 & 40 & 49.4 & 42.5 & 2.5 & i & i & 3 & 1.0 & $i$ & 2 & 3 & 1.0 & 6 & 1964 & 0.9 & 172 & 1 & \\
\hline 5 & 41 & 73.0 & 56.4 & 9.0 & 1 & 1 & 3 & 1.0 & 1 & 2 & 2 & 1.0 & 5 & 1975 & 1.0 & 875 & 1 & \\
\hline 5 & 42 & 67.2 & 50.0 & 4.3 & i & i & 3 & 1.0 & $i$ & 1 & 2 & 1.5 & 5 & 1982 & 0.8 & 250 & 1 & \\
\hline 5 & 43 & 0.0 & 17.7 & 17.5 & 15 & 1 & & 0.0 & & & & 0.0 & & & 0.0 & 1500 & 1 & \\
\hline 5 & 44 & 55.0 & 54.1 & 6.0 & 1 & i & 3 & 1.5 & 1 & 2 & 1 & 1.0 & 4 & 1944 & 0.8 & 1200 & & \\
\hline 5 & 45 & 0.0 & 44.1 & 4.7 & 13 & 1 & & 0.0 & & & & 0.0 & & & 0.0 & 225 & & \\
\hline 5 & $45 \mathrm{~A}$ & 114.2 & 57.1 & 8.0 & 1 & $i$ & 4 & 1.5 & 1 & 2 & 4 & 1.5 & 7 & 1988 & 1.1 & 1075 & & \\
\hline 5 & 46 & 118.6 & 105.8 & 89.0 & 1 & 1 & 5 & 2.0 & 1 & 2 & 3 & 1.5 & 8 & 1820 & 1.1 & 1700 & 1 & \\
\hline 5 & 47 & 0.0 & 87.3 & 68.5 & 13 & 1 & & 0.0 & & & & 0.0 & & & 0.0 & 550 & 1 & \\
\hline 5 & $47 \mathrm{~A}$ & 108.5 & 59.4 & 9.5 & 1 & $i$ & 4 & 1.5 & 1 & 2 & 3 & 2.0 & 7 & 1987 & 1.1 & 300 & & \\
\hline 5 & 49 & 0.0 & 61.2 & 27.0 & 13 & 1 & & 0.0 & & & & 0.0 & & & 0.0 & 450 & 1 & \\
\hline 5 & 50 & 36.2 & 95.0 & 67.0 & 11 & 1 & 2 & 1.0 & 1 & 1 & & 1.0 & 1 & 1950 & 1.6 & & & \\
\hline 5 & 52 & 0.0 & 0.0 & 0.0 & 1 & 1 & 2 & 1.0 & 1 & 3 & 1 & 1.0 & 4 & 1935 & 0.7 & & & \\
\hline 5 & 52 & 86.8 & 69.5 & 20.0 & 1 & 1 & 3 & 1.0 & 2 & 2 & 2 & 1.5 & 6 & 1935 & 0.8 & & & \\
\hline
\end{tabular}




\begin{tabular}{|c|c|c|c|c|c|c|c|c|c|c|c|c|c|c|c|c|c|c|}
\hline Map & Lot & $\begin{array}{l}\text { Bldg. } \\
\text { Value }\end{array}$ & $\begin{array}{l}\text { Land } \\
\text { Value }\end{array}$ & Acres & $\begin{array}{l}\text { Land } \\
\text { Use }\end{array}$ & Zoning & $\begin{array}{l}\text { Bldg. } \\
\text { Grade }\end{array}$ & $\begin{array}{l}\text { \# of } \\
\text { Stories }\end{array}$ & $\begin{array}{l}\text { Occu- } \\
\text { pancy }\end{array}$ & $\begin{array}{l}\text { Heat } \\
\text { Type }\end{array}$ & $\begin{array}{l}\text { \# of } \\
\text { Beds }\end{array}$ & $\begin{array}{l}\text { " of } \\
\text { Baths }\end{array}$ & $\begin{array}{l}\text { Total } \\
\text { Rooms }\end{array}$ & $\begin{array}{l}\text { Year } \\
\text { Built }\end{array}$ & $\begin{array}{l}\text { 1st } \\
\text { Floor }\end{array}$ & Frontage & $\begin{array}{l}\text { Wet- } \\
\text { lands }\end{array}$ & $\begin{array}{l}\text { Water- } \\
\text { shed }\end{array}$ \\
\hline 5 & 53 & 51.6 & 43.1 & 2.8 & 1 & 1 & 2 & 1.0 & 1 & 2 & 3 & 1.0 & 6 & 1955 & 0.7 & & & \\
\hline 5 & 54 & 73.5 & 75.4 & 30.1 & 1 & 1 & 4 & 1.0 & 1 & 2 & 3 & 1.0 & 7 & 1800 & 1.2 & 2350 & & \\
\hline 5 & 55 & 88.4 & 66.9 & 16.0 & 1 & 1 & 4 & 1.0 & 1 & 2 & 3 & 1.0 & 9 & 1800 & 1.2 & 837 & & \\
\hline 5 & 56 & 0.0 & 49.9 & 8.4 & 13 & 1 & & 0.0 & & & & 0.0 & & & 0.0 & 1140 & & \\
\hline 5 & $56 \mathrm{~A}$ & 95.8 & 57.1 & 8.0 & 1 & 1 & 3 & 1.0 & 1 & 2 & 2 & 1.0 & 5 & 1979 & 1.4 & 755 & & \\
\hline 5 & 57 & 92.9 & 60.1 & 10.0 & 1 & 1 & 3 & 1.0 & 1 & 2 & 3 & 1.0 & 8 & 1790 & 2.0 & 1500 & & \\
\hline 5 & 58 & 0.0 & 44.6 & 5.0 & 13 & 1 & & 0.0 & & & & 0.0 & & & 0.0 & 960 & & \\
\hline 5 & 59 & 93.9 & 54.1 & 6.0 & 1 & 1 & 1 & 4.0 & 1 & 2 & 4 & 1.0 & 10 & 1790 & 1.6 & 1100 & & \\
\hline 5 & 60 & 0.0 & 62.8 & 22.0 & 13 & 1 & & 0.0 & & & & 0.0 & & & 0.0 & 419 & & \\
\hline 5 & 60A & 139.7 & 65.1 & 13.8 & 1 & 1 & 4 & 2.0 & 1 & 2 & 3 & 2.0 & 8 & 1978 & 1.5 & 325 & & \\
\hline 5 & $60 \mathrm{~B}$ & 36.3 & 52.6 & 5.0 & 1 & 1 & 3 & 1.0 & 1 & 2 & 1 & 1.0 & 3 & 1900 & 0.4 & 415 & & \\
\hline 5 & 61 & 124.3 & 48.8 & 4.0 & 1 & 1 & 4 & 1.0 & 1 & 2 & 3 & 2.0 & 7 & 1970 & 2.0 & 735 & & \\
\hline 5 & 62 & 77.3 & 52.5 & 5.0 & 1 & 1 & 3 & 1.0 & 1 & 5 & 4 & 1.0 & 6 & 1979 & 1.5 & 599 & & 1 \\
\hline 5 & $62 A$ & 95.0 & 52.1 & 4.7 & 1 & 1 & 4 & 2.0 & 1 & 2 & 3 & 1.5 & 7 & 1987 & 0.9 & 983 & & 1 \\
\hline 5 & $62 B$ & 5.0 & 52.3 & 4.8 & 1 & 1 & & 0.0 & & & & 0.0 & & & 0.0 & 569 & & 1 \\
\hline 5 & $62 \mathrm{C}$ & 0.0 & 45.0 & 5.3 & 13 & 1 & & 0.0 & & & & 0.0 & & & 0.0 & 300 & & 1 \\
\hline 5 & 62D & 0.0 & 44.2 & 4.7 & 13 & 1 & & 0.0 & & & & 0.0 & & & 0.0 & 364 & & 1 \\
\hline 5 & 63 & 0.0 & 64.5 & 25.0 & 13 & 1 & & 0.0 & & & & 0.0 & & & 0.0 & 25 & & 1 \\
\hline 5 & $63 \mathrm{~A}$ & 0.0 & 46.3 & 6.1 & 75 & 1 & & 0.0 & & & & 0.0 & & & 0.0 & 234 & & 1 \\
\hline 5 & 63B & 0.0 & 46.8 & 12.0 & 13 & 1 & & 0.0 & & & & 0.0 & & & 0.0 & 206 & & 1 \\
\hline 5 & $63 \mathrm{~B} 1$ & 180.0 & 53.9 & 5.8 & 1 & 1 & 5 & 2.0 & 1 & 2 & 3 & 2.5 & 8 & 1986 & 1.7 & 363 & & 1 \\
\hline 5 & $63 \mathrm{~B} 1 \mathrm{~A}$ & 0.0 & 45.9 & 5.8 & 13 & 1 & & 0.0 & & & & 0.0 & & & 0.0 & 362 & & 1 \\
\hline 5 & $63 C$ & 0.0 & 10.1 & 6.7 & 13 & 1 & & 0.0 & & & & 0.0 & & & 0.0 & & & 1 \\
\hline 5 & 64 & 0.0 & 117.2 & 160.0 & 13 & 1 & & 0.0 & & & & 0.0 & & & 0.0 & 2250 & & \\
\hline 5 & 65 & 106.1 & 61.2 & 11.0 & 1 & 1 & 3 & 1.5 & 1 & 2 & 4 & 1.0 & 8 & 1900 & 1.4 & 1536 & & \\
\hline 5 & 66 & 50.1 & 16.1 & 2.0 & 1 & 1 & 3 & 1.0 & 1 & 2 & 1 & 1.0 & 4 & 1974 & 0.8 & 750 & & \\
\hline 5 & 67 & 79.3 & 70.8 & 22.0 & 1 & 1 & 3 & 1.0 & 1 & 2 & 3 & 1.5 & 6 & 1977 & 1.4 & 773 & & \\
\hline 5 & 68 & 73.1 & 70.1 & 21.0 & 1 & 1 & 3 & 1.0 & 1 & 4 & 3 & 2.0 & 7 & 1968 & 1.2 & 200 & & \\
\hline 5 & 69 & 0.0 & 53.2 & 11.0 & 13 & 1 & & 0.0 & & & & 0.0 & & & 0.0 & 900 & & \\
\hline 5 & 70 & 133.9 & 77.7 & 33.9 & 1 & 1 & 3 & 1.0 & 1 & 2 & 3 & 2.5 & 7 & 1988 & 2.2 & 371 & 1 & \\
\hline 5 & 71 & 82.1 & 73.0 & 34.0 & 1 & 1 & 3 & 1.0 & 1 & 4 & 3 & 1.0 & 6 & 1974 & 1.5 & 1000 & 1 & \\
\hline 6 & 1 & 72.9 & 45.5 & 3.3 & 1 & 1 & 3 & 1.0 & 1 & 2 & 4 & 1.0 & 9 & 1850 & 1.0 & 300 & & 1 \\
\hline 6 & 2 & 0.0 & 59.1 & 24.0 & 15 & 1 & & 0.0 & & & & 0.0 & & & 0.0 & 1450 & 1 & 1 \\
\hline 6 & 3 & 28.2 & 55.6 & 7.0 & 1 & 3 & 1 & 1.0 & 1 & 2 & 1 & 1.0 & 5 & 1940 & 1.0 & 2100 & & 1 \\
\hline 6 & 4 & 66.1 & 55.6 & 7.0 & 1 & 3 & 3 & 1.0 & 1 & 4 & 2 & 1.0 & 7 & 1945 & 1.1 & 300 & & 1 \\
\hline 6 & 5 & 80.9 & 71.1 & 24.2 & 1 & 1 & 3 & 1.0 & 1 & 4 & 3 & 1.5 & 6 & 1977 & 1.4 & 1840 & 1 & 1 \\
\hline 6 & 6 & 99.3 & 104.8 & 86.0 & 1 & 1 & 4 & 1.5 & 1 & 2 & 4 & 1.0 & 10 & 1929 & 1.3 & 1625 & 1 & 1 \\
\hline 6 & $6 \mathrm{~A}$ & 0.0 & 7.5 & 5.0 & 71 & 1 & & 0.0 & & & & 0.0 & & & 0.0 & & & 1 \\
\hline 6 & 7 & 70.9 & 38.5 & 1.7 & 1 & 1 & 3 & 1.0 & 1 & 2 & 3 & 1.0 & 6 & 1975 & 0.9 & 272 & & 1 \\
\hline 6 & 9 & 0.0 & 46.1 & 6.0 & 13 & 1 & & 0.0 & & & & 0.0 & & & 0.0 & 425 & & 1 \\
\hline
\end{tabular}




$\begin{array}{llrrrr}\text { Map } & \text { Lat } & \begin{array}{r}\text { Bldg. } \\ \text { Value }\end{array} & \begin{array}{r}\text { Land } \\ \text { Value }\end{array} & \text { Acres } & \text { Land } \\ & & & \text { Use } \\ 6 & 9 \mathrm{~A} & 70.6 & 59.8 & 9.8 & 1 \\ 6 & 10 & 66.9 & 49.8 & 4.2 & 1 \\ 6 & 11 & 73.2 & 51.0 & 4.5 & 1 \\ 6 & 12 & 0.0 & 79.5 & 52.3 & 13 \\ 6 & 12 \mathrm{~A} & 0.0 & 48.5 & 4.9 & 13 \\ 6 & 12 \mathrm{~B} & 135.5 & 52.1 & 4.6 & 1 \\ 6 & 12 \mathrm{C} & 131.7 & 58.1 & 4.6 & 1 \\ 6 & 12 \mathrm{D} & 225.6 & 59.6 & 5.6 & 1 \\ 6 & 12 \mathrm{E} & 106.9 & 58.1 & 4.6 & 1 \\ 6 & 12 \mathrm{~F} & 0.0 & 44.5 & 4.9 & 13 \\ 6 & 12 \mathrm{G} & 107.4 & 48.0 & 4.6 & 1 \\ 6 & 12 \mathrm{H} & 145.4 & 53.8 & 5.8 & 1 \\ 6 & 12 \mathrm{I} & 0.0 & 48.1 & 4.6 & 13 \\ 6 & 12 \mathrm{~J} & 66.7 & 58.1 & 4.6 & 1 \\ 6 & 12 \mathrm{~K} & 131.4 & 58.1 & 4.6 & 1 \\ 6 & 13 & 0.0 & 56.2 & 14.8 & 13 \\ 6 & 13 \mathrm{~A} & 123.9 & 55.3 & 6.8 & 1 \\ 6 & 13 \mathrm{~B} & 165.6 & 56.3 & 7.5 & 1 \\ 6 & 14 & 86.0 & 52.1 & 4.7 & 1 \\ 6 & 14 & 0.0 & 145.3 & 191.3 & 13 \\ 6 & 1401 & 0.0 & 44.0 & 4.6 & 13 \\ 6 & 1402 & 86.0 & 52.1 & 4.7 & 1 \\ 6 & 1403 & 0.0 & 44.0 & 4.6 & 13 \\ 6 & 14 \mathrm{~A} & \mathbf{7 9 . 5} & \mathbf{7 4 . 9} & 29.3 & 1 \\ 6 & 14 \mathrm{~B} & 158.5 & 73.6 & 26.9 & 1 \\ 6 & 14 \mathrm{C} & 0.0 & 208.0 & 34.7 & 10 \\ 6 & 14 \mathrm{D} & 0.0 & 21.6 & 23.0 & 15 \\ 6 & 14 \mathrm{E} & 0.0 & 31.6 & 1.2 & 15 \\ 6 & 14 \mathrm{~F} & 0.0 & 96.0 & 16.0 & 10 \\ 6 & 14 \mathrm{G} & 109.1 & 52.6 & 5.0 & 1 \\ 6 & 14 \mathrm{H} & 0.0 & 52.6 & 5.0 & 15 \\ 6 & 14 \mathrm{I} & 0.0 & 11.6 & 9.1 & 15 \\ 6 & 15 & 0.0 & 61.5 & 20.0 & 13 \\ 6 & 15 \mathrm{~B} & 0.0 & 5.8 & 0.0 & 10 \\ 6 & 16 & 0.0 & 262.5 & 25.0 & 10 \\ 6 & 17 & 0.0 & 85.8 & 102.0 & 13 \\ 6 & 18 & 312.3 & 84.4 & 46.0 & 1 \\ 6 & 19 & 51.3 & 40.1 & 2.0 & 1 \\ 6 & 19 \mathrm{~A} & 57.8 & 40.1 & 2.0 & 1 \\ 6 & 20 & 0.0 & 45.3 & 5.5 & 13\end{array}$
$\begin{array}{llllllll}\text { Zoning } & \text { Bldg. } & \text { \# of } & \text { Occu- } & \text { Heat } & \text { \# of } & \text { \# of } & \text { Total } \\ & \text { Grade } & \text { Stories } & \text { pancy } & \text { Type } & \text { Beds } & \text { Baths } & \text { Rooms }\end{array}$

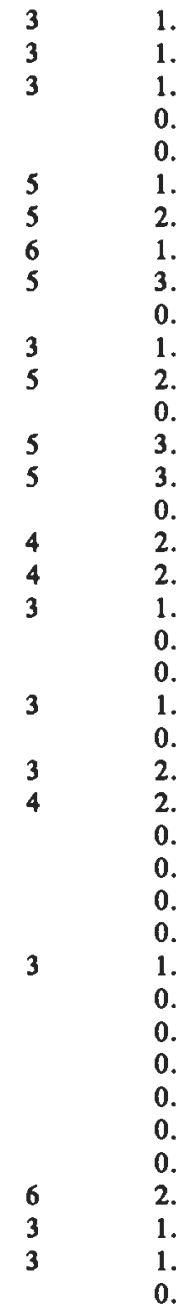

0.0
0.0

0

.0

0.0

1.0
1.5
0.0
Year 1st Frontage Wet- WaterBuilt Floor

$\begin{array}{rrr}1987 & 0.9 & 450 \\ 1975 & 0.9 & 85\end{array}$

$\begin{array}{lll}1972 \quad 1.2 & 85\end{array}$

$\begin{array}{ll} & 0.0 \\ 1978 & 0.0 \\ 1979 & 1.1\end{array}$

$1979 \quad 1.0$

19792.9

1989

1989

$1989 \quad 0.2$

$1989 \quad 1.5$

1989

$\begin{array}{ll}1981 & 0.0 \\ 1982 & 1.4\end{array}$

$1982 \quad 1.4$

1989

1989

$1989 \quad 1.2$

$1870 \quad 1.1$

1985

1.1
1.4
0.0
0.0

0.0
0.0
0.0

0.0
0.0

$1982 \quad 2.0$

0.0
0.0
0.0

0.0
0.0
450

lands shed

651

568

900

424

\section{7}

300

400

1300
600

600

600

600

376

376
600

600

1850

2450

400

850 $\begin{array}{ll}2 & 4 \\ 2 & 3 \\ 4 & 2\end{array}$ 


\begin{tabular}{|c|c|c|c|c|c|c|c|c|c|c|c|c|c|c|c|c|c|c|}
\hline Map & Lot & $\begin{array}{l}\text { Bldg. } \\
\text { Value }\end{array}$ & $\begin{array}{l}\text { Land } \\
\text { Value }\end{array}$ & Acres & $\begin{array}{l}\text { Land } \\
\text { Use }\end{array}$ & Zoning & $\begin{array}{l}\text { Bldg. } \\
\text { Grade }\end{array}$ & $\begin{array}{l}\text { of } \\
\text { Stories }\end{array}$ & $\begin{array}{l}\text { Occu- } \\
\text { pancy }\end{array}$ & $\begin{array}{l}\text { Heat } \\
\text { Type }\end{array}$ & $\begin{array}{l}\text { \# of } \\
\text { Beds }\end{array}$ & $\begin{array}{l}\text { " of } \\
\text { Baths }\end{array}$ & $\begin{array}{l}\text { Total } \\
\text { Rooms }\end{array}$ & $\begin{array}{l}\text { Year } \\
\text { Built }\end{array}$ & $\begin{array}{l}\text { 1st } \\
\text { Floor }\end{array}$ & Frontage & $\begin{array}{l}\text { Wet- } \\
\text { lands }\end{array}$ & $\begin{array}{l}\text { Water- } \\
\text { shed }\end{array}$ \\
\hline 6 & $20 \mathrm{~A}$ & 68.6 & 53.2 & 5.4 & 1 & 1 & 1 & 2.0 & 1 & 2 & 3 & 1.5 & 5 & 1976 & 1.1 & 390 & & 1 \\
\hline 6 & 20B & 97.6 & 52.1 & 4.7 & 1 & 1 & 4 & 1.5 & 1 & 2 & 2 & 2.0 & 5 & 1977 & 0.9 & 300 & & 1 \\
\hline 6 & 20D & 91.8 & 52.4 & 4.9 & 1 & 1 & 3 & 1.0 & 1 & 2 & 3 & 1.5 & 5 & 1989 & 1.5 & 300 & & 1 \\
\hline 6 & $20 \mathrm{E}$ & 0.0 & 53.2 & 11.0 & 13 & 1 & & 0.0 & & & & 0.0 & & & 0.0 & & & 1 \\
\hline 6 & 21 & 0.0 & 61.5 & 20.0 & 78 & 1 & & 0.0 & & & & 0.0 & & & 0.0 & & 1 & 1 \\
\hline 6 & $21 \mathrm{~A}$ & 0.0 & 136.5 & 13.0 & 10 & 1 & & 0.0 & & & & 0.0 & & & 0.0 & & 1 & 1 \\
\hline 6 & $21 B$ & 0.0 & 15.0 & 11.0 & 15 & 1 & & 0.0 & & & & 0.0 & & & 0.0 & & & 1 \\
\hline 6 & 22 & 0.0 & 20.7 & 20.0 & 13 & 1 & & 0.0 & & & & 0.0 & & & 0.0 & & 1 & 1 \\
\hline 6 & 23 & 61.9 & 51.2 & 4.5 & 1 & 1 & 3 & 1.5 & 1 & 1 & 4 & 2.0 & 10 & 1800 & 1.1 & 700 & 1 & 1 \\
\hline 6 & $23 \mathrm{~A}$ & 0.0 & 1.7 & 0.2 & 10 & 1 & & 0.0 & & & & 0.0 & & & 0.0 & 65 & & 1 \\
\hline 6 & 24 & 0.0 & 30.0 & 5.0 & 10 & 1 & & 0.0 & & & & 0.0 & & & 0.0 & 318 & & 1 \\
\hline 6 & 25 & 0.0 & 46.1 & 6.0 & 13 & 1 & & 0.0 & & & & 0.0 & & & 0.0 & 854 & & 1 \\
\hline 6 & $25 \mathrm{AE}$ & 0.0 & 4.1 & 0.0 & 10 & 1 & & 0.0 & & & & 0.0 & & & 0.0 & 625 & & 1 \\
\hline 6 & 26 & 0.0 & 346.5 & 33.0 & 10 & 1 & & 0.0 & & & & 0.0 & & & 0.0 & 1200 & 1 & 1 \\
\hline 6 & $26 \mathrm{~A}$ & 0.0 & 44.4 & 4.9 & 13 & 1 & & 0.0 & & & & 0.0 & & & 0.0 & & & 1 \\
\hline 6 & $26 \mathrm{Al}$ & 0.0 & 44.6 & 5.0 & 13 & 1 & & 0.0 & & & & 0.0 & & & 0.0 & & & 1 \\
\hline 6 & 27 & 9.8 & 107.5 & 94.6 & 12 & 1 & 1 & 0.0 & 0 & 1 & & 0.0 & & 1930 & 0.7 & 3000 & 1 & 1 \\
\hline 6 & $27 \mathrm{~A}$ & 0.0 & 4.2 & 0.3 & 15 & 1 & & 0.0 & & & & 0.0 & & & 0.0 & & & 1 \\
\hline 6 & 27AE & 0.0 & 42.0 & 0.0 & 10 & 1 & & 0.0 & & & & 0.0 & & & 0.0 & & & 1 \\
\hline 6 & 28 & 0.0 & 58.4 & 15.2 & 13 & 1 & & 0.0 & & & & 0.0 & & & 0.0 & 620 & & 1 \\
\hline 6 & $28 \mathrm{~A}$ & 0.0 & 47.3 & 6.8 & 13 & 1 & & 0.0 & & & & 0.0 & & & 0.0 & & & 1 \\
\hline 6 & 29 & 0.0 & 46.0 & 5.9 & 13 & 1 & & 0.0 & & & & 0.0 & & & 0.0 & 474 & & 1 \\
\hline 6 & $29 A$ & 158.6 & 57.0 & 7.9 & 1 & 1 & 4 & 2.0 & 1 & 2 & 3 & 2.0 & 10 & 1978 & 2.2 & 250 & & 1 \\
\hline 6 & $29 \mathrm{~A} 1$ & 143.7 & 56.0 & 7.2 & 1 & 1 & 4 & 1.0 & 1 & 4 & 2 & 2.0 & 5 & 1983 & 1.3 & 308 & & 1 \\
\hline 6 & $29 \mathrm{~A} 2$ & 99.8 & 56.9 & 7.9 & 1 & 1 & 4 & 1.5 & 1 & 4 & 2 & 2.0 & 5 & 1979 & 1.0 & 300 & & 1 \\
\hline 6 & $29 \mathrm{AE}$ & 0.0 & 44.3 & 0.0 & 10 & 1 & & 0.0 & & & & 0.0 & & & 0.0 & & & 1 \\
\hline 6 & 29B & 0.0 & 44.0 & 4.6 & 13 & 1 & & 0.0 & & & & 0.0 & & & 0.0 & & & 1 \\
\hline 6 & 30 & 0.0 & 7.5 & 5.0 & 13 & 1 & & 0.0 & & & & 0.0 & & & 0.0 & & 1 & 1 \\
\hline 6 & 32 & 0.0 & 7.1 & 4.7 & 15 & 1 & & 0.0 & & & & 0.0 & & & 0.0 & & & 1 \\
\hline 6 & 33 & 0.0 & 4.5 & 3.0 & 13 & 1 & & 0.0 & & & & 0.0 & & & 0.0 & & & 1 \\
\hline 6 & 35 & 59.0 & 53.3 & 6.9 & 1 & 1 & 3 & 1.5 & 1 & 2 & 3 & 1.0 & 5 & 1946 & 0.6 & 550 & 1 & 1 \\
\hline 6 & $35 \mathrm{~A}$ & 0.0 & 60.1 & 17.9 & 13 & 1 & & 0.0 & & & & 0.0 & & & 0.0 & 600 & & 1 \\
\hline 6 & 35B & 224.7 & 53.1 & 5.3 & 2 & 1 & 5 & 1.5 & 3 & 2 & 5 & 3.5 & 14 & 1975 & 2.1 & 321 & 1 & 1 \\
\hline 6 & $35 \mathrm{C}$ & 70.5 & 52.1 & 4.7 & 1 & 1 & 3 & 1.0 & 1 & 2 & 4 & 1.0 & 6 & 1977 & 0.9 & 330 & & 1 \\
\hline 6 & 35D & 84.5 & 69.4 & 19.8 & 1 & 1 & 3 & 1.5 & 1 & 2 & 3 & 1.5 & 6 & 1983 & 0.9 & 406 & & 1 \\
\hline 6 & 35D1 & 2.5 & 54.6 & 12.0 & 13 & 1 & & 0.0 & & & & 0.0 & & & 0.0 & 310 & 1 & 1 \\
\hline 6 & 36 & 107.5 & 40.1 & 2.0 & 1 & 1 & 3 & 1.5 & 1 & 2 & 3 & 2.0 & 7 & 1966 & 1.2 & 200 & & 1 \\
\hline 6 & 37 & 7.4 & 38.5 & 3.4 & 13 & 1 & & 0.0 & & & & 0.0 & & & 0.0 & 300 & & 1 \\
\hline 6 & $37 \mathrm{~A}$ & 85.2 & 52.1 & 4.6 & 1 & 1 & 3 & 1.0 & 1 & 2 & 3 & 1.5 & 6 & 1970 & 1.2 & 851 & & 1 \\
\hline 6 & 38 & 0.0 & 28.0 & 0.6 & 13 & 1 & & 0.0 & & & & 0.0 & & & 0.0 & 150 & & 1 \\
\hline
\end{tabular}




\begin{tabular}{|c|c|c|c|c|c|c|c|c|c|c|c|c|c|c|c|c|c|c|}
\hline Map & Lot & $\begin{array}{l}\text { Bldg. } \\
\text { Value }\end{array}$ & $\begin{array}{l}\text { Land } \\
\text { Value }\end{array}$ & Acres & $\begin{array}{l}\text { Land } \\
\text { Use }\end{array}$ & Zoning & $\begin{array}{l}\text { Bldg. } \\
\text { Grade }\end{array}$ & $\begin{array}{l}\text { \# of } \\
\text { Stories }\end{array}$ & $\begin{array}{l}\text { Occu- } \\
\text { pancy }\end{array}$ & $\begin{array}{l}\text { Heat } \\
\text { Type }\end{array}$ & $\begin{array}{l}\text { \# of } \\
\text { Beds }\end{array}$ & $\begin{array}{l}\text { \# of } \\
\text { Baths }\end{array}$ & $\begin{array}{l}\text { Total } \\
\text { Rooms }\end{array}$ & $\begin{array}{l}\text { Year } \\
\text { Built }\end{array}$ & $\begin{array}{l}\text { 1st } \\
\text { Floor }\end{array}$ & Frontage & $\begin{array}{l}\text { Wet- } \\
\text { lands }\end{array}$ & $\begin{array}{l}\text { Water- } \\
\text { shed }\end{array}$ \\
\hline 6 & 39 & 253.6 & 75.1 & 22.8 & 11 & 1 & 3 & 1.0 & 1 & 2 & 2 & 1.0 & 5 & 1960 & 1.3 & 2160 & 1 & 1 \\
\hline 6 & 40 & 75.0 & 99.3 & 81.0 & 1 & 1 & 4 & 1.0 & 1 & 2 & 3 & 1.0 & 5 & 1778 & 1.1 & 1150 & & 1 \\
\hline 6 & 41 & 64.2 & 18.2 & 55.0 & 1 & 1 & 3 & 1.5 & 1 & 2 & 3 & 1.0 & 6 & 1780 & 1.0 & 1160 & 1 & 1 \\
\hline 6 & $41 \mathrm{~A}$ & 93.4 & 52.6 & 5.0 & 1 & 1 & 3 & 1.5 & 1 & 4 & 2 & 1.0 & 5 & 1987 & 0.9 & 350 & & 1 \\
\hline 6 & 43 & 96.0 & 52.1 & 4.6 & 1 & 1 & 4 & 1.0 & 1 & 2 & 3 & 1.5 & 6 & 1976 & 1.3 & 540 & 1 & 1 \\
\hline 6 & 45 & 0.0 & 50.8 & 8.7 & 15 & 1 & & 0.0 & & & & 0.0 & & & 0.0 & 300 & & 1 \\
\hline 6 & 46 & 110.8 & 52.0 & 4.6 & 1 & 1 & 4 & 1.0 & 1 & 2 & 2 & 2.5 & 7 & 1977 & 1.3 & 300 & & 1 \\
\hline 6 & 47 & 0.0 & 45.4 & 5.5 & 13 & 1 & & 0.0 & & & & 0.0 & & & 0.0 & 300 & & 1 \\
\hline 6 & 48 & 0.0 & 60.2 & 18.0 & 13 & 1 & & 0.0 & & & & 0.0 & & & 0.0 & & & 1 \\
\hline 7 & CEM & 0.0 & 0.0 & 0.0 & C & 1 & & 0.0 & & & & 0.0 & & & 0.0 & & & \\
\hline 7 & 1 & 27.0 & 44.4 & 3.0 & 1 & 1 & 4 & 2.0 & 1 & 2 & 1 & 0.0 & 2 & 1804 & 0.2 & 500 & & \\
\hline 7 & 2 & 132.3 & 91.2 & 50.0 & 1 & 1 & 4 & 1.0 & 1 & 2 & 3 & 1.5 & 6 & 1970 & 2.1 & 3200 & & \\
\hline 7 & 3 & 291.6 & 70.8 & 23.0 & 72 & 1 & 1 & 0.0 & 0 & 2 & 0 & 0.0 & 0 & 1850 & 4.3 & 1400 & 1 & \\
\hline 7 & 4 & 0.0 & 64.1 & 24.4 & 13 & 1 & & 0.0 & & & & 0.0 & & & 0.0 & 1050 & & \\
\hline 7 & $4 \mathrm{~A}$ & 130.6 & 52.1 & 4.6 & 1 & 1 & 4 & 2.0 & 1 & 2 & 4 & 2.0 & 7 & 1987 & 1.2 & 783 & & \\
\hline 7 & 5 & 0.0 & 44.8 & 6.5 & 13 & 1 & & 0.0 & & & & 0.0 & & & 0.0 & 300 & & \\
\hline 7 & 6 & 70.6 & 36.6 & 1.0 & 1 & 1 & 3 & 1.0 & 1 & 2 & 2 & 1.0 & & 1960 & 0.9 & 157 & & \\
\hline 7 & 7 & 55.4 & 38.5 & 1.7 & 1 & 1 & 3 & 1.0 & 1 & 2 & 3 & 1.0 & 6 & 1963 & 1.1 & 185 & & \\
\hline 7 & 8 & 74.9 & 38.9 & 1.8 & 1 & 1 & 3 & 1.0 & 1 & 2 & 3 & 1.0 & 6 & 1959 & 0.9 & 187 & & \\
\hline 7 & 9 & 58.9 & 40.5 & 2.0 & 1 & 1 & 3 & 1.0 & 1 & 2 & 3 & 1.0 & 6 & 1958 & 1.0 & 220 & & \\
\hline 7 & 10 & 60.4 & 43.5 & 2.7 & 1 & 1 & 3 & 1.0 & 1 & 2 & 2 & 1.0 & 5 & 1961 & 1.0 & 295 & & \\
\hline 7 & 11 & 136.7 & 86.5 & 50.0 & 1 & 1 & 4 & 2.0 & 1 & 2 & 4 & 1.5 & 8 & 1852 & 1.6 & 1900 & & \\
\hline 7 & 12 & 74.8 & 61.9 & 11.0 & 1 & 1 & 4 & 1.0 & 1 & 1 & 4 & 1.0 & 10 & 1830 & 1.6 & 1550 & & \\
\hline 7 & $12 \mathrm{~A}$ & 5.0 & 57.8 & 8.5 & 1 & 1 & & 0.0 & & & & 0.0 & & & 0.0 & & & \\
\hline 7 & 13 & 0.3 & 82.9 & 58.6 & 15 & 1 & & 0.0 & & & & 0.0 & & & 0.0 & 300 & 1 & \\
\hline 7 & $13 \mathrm{~A}$ & 70.7 & 52.1 & 4.6 & 1 & 1 & 3 & 1.0 & 1 & 2 & 3 & 2.0 & 5 & 1976 & 1.1 & 330 & 1 & \\
\hline 7 & $13 \mathrm{~B}$ & 87.7 & 52.6 & 5.0 & 1 & 1 & 3 & 1.0 & 1 & 2 & 2 & 2.5 & 4 & 1988 & 1.4 & 839 & & \\
\hline 7 & 14 & 0.0 & 23.6 & 25.0 & 13 & 1 & & 0.0 & & & & 0.0 & & & 0.0 & 0 & 1 & \\
\hline 7 & 15 & 62.5 & 72.5 & 25.0 & 1 & 1 & 3 & 1.5 & 1 & 2 & 3 & 1.0 & 5 & 1958 & 0.9 & 500 & 1 & \\
\hline 7 & 16 & 57.9 & 49.3 & 4.2 & 1 & 1 & 3 & 1.0 & 1 & 2 & 2 & 1.0 & 4 & 1947 & 1.0 & 304 & & \\
\hline 7 & 17 & 69.0 & 59.2 & 9.4 & 1 & 1 & 3 & 1.0 & 1 & 1 & 2 & 1.0 & 4 & 1966 & 1.6 & 1990 & & \\
\hline 7 & $17 \mathrm{~A}$ & 103.3 & 52.1 & 4.6 & 1 & 1 & 4 & 1.0 & 1 & 2 & 3 & 2.5 & 6 & 1986 & 1.3 & 312 & & \\
\hline 7 & 18 & 83.6 & 67.5 & 16.8 & 1 & 1 & 3 & 1.0 & 1 & 2 & 3 & 1.0 & 8 & 1979 & 1.4 & 0 & 1 & \\
\hline 7 & 19 & 0.0 & 15.0 & 10.0 & 15 & 1 & & 0.0 & & & & 0.0 & & & 0.0 & 0 & & \\
\hline 7 & 20 & 0.0 & 72.9 & 39.8 & 15 & 1 & & 0.0 & & & & 0.0 & & & 0.0 & 50 & 1 & \\
\hline 7 & $20 \mathrm{~A}$ & 102.1 & 52.3 & 4.8 & 1 & 1 & 4 & 2.0 & 1 & 2 & 3 & 2.5 & 7 & 1989 & 1.2 & 300 & & \\
\hline 7 & $20 \mathrm{~B}$ & 71.2 & 52.6 & 5.0 & $i$ & 1 & 3 & 1.0 & $i$ & 2 & 3 & 1.0 & 4 & 1986 & 1.2 & 301 & & \\
\hline 7 & $20 C$ & 123.7 & 52.6 & 5.0 & 1 & 1 & 4 & 2.0 & 1 & 2 & 3 & 2.5 & 7 & 1983 & 1.3 & 300 & & \\
\hline 7 & 20D & 0.0 & 44.6 & 5.0 & 13 & 1 & & 0.0 & & & & 0.0 & & & 0.0 & 316 & & \\
\hline 7 & 21 & 0.0 & 35.9 & 2.5 & 13 & 1 & & 0.0 & & & & 0.0 & & & 0.0 & 700 & & \\
\hline
\end{tabular}




\begin{tabular}{|c|c|c|c|c|c|c|c|c|c|c|c|c|c|c|c|c|c|c|}
\hline Map & Lot & $\begin{array}{l}\text { Bldg. } \\
\text { Value }\end{array}$ & $\begin{array}{l}\text { Land } \\
\text { Value }\end{array}$ & Acres & $\begin{array}{l}\text { Land } \\
\text { Use }\end{array}$ & Zoning & $\begin{array}{l}\text { Bldg. } \\
\text { Grade }\end{array}$ & $\begin{array}{l}\text { \# of } \\
\text { Stories }\end{array}$ & $\begin{array}{l}\text { Occu- } \\
\text { pancy }\end{array}$ & $\begin{array}{l}\text { Heat } \\
\text { Type }\end{array}$ & $\begin{array}{l}\text { \# of } \\
\text { Beds }\end{array}$ & $\begin{array}{l}\text { of } \\
\text { Baths }\end{array}$ & $\begin{array}{l}\text { Total } \\
\text { Rooms }\end{array}$ & $\begin{array}{l}\text { Year } \\
\text { Built }\end{array}$ & $\begin{array}{l}\text { 1st } \\
\text { Floor }\end{array}$ & Frontage & $\begin{array}{l}\text { Wet- } \\
\text { lands }\end{array}$ & $\begin{array}{l}\text { Water- } \\
\text { shed }\end{array}$ \\
\hline 7 & 22 & 29.6 & 92.4 & 61.0 & 1 & 1 & 2 & 1.0 & 1 & 2 & 2 & 1.0 & 4 & 1947 & 0.5 & 850 & & \\
\hline 7 & 23 & 0.0 & 6.7 & 0.8 & 13 & 1 & & 0.0 & & & & 0.0 & & & 0.0 & 385 & & \\
\hline 7 & 24 & 72.8 & 40.1 & 2.0 & 1 & 1 & 3 & 1.0 & 1 & 2 & 3 & 1.0 & 5 & 1954 & 1.2 & 381 & & \\
\hline 7 & 25 & 0.0 & 63.4 & 23.0 & 13 & 1 & & 0.0 & & & & 0.0 & & & 0.0 & 1100 & & \\
\hline 7 & $25 \mathrm{~A}$ & 130.2 & 52.6 & 5.0 & 1 & 1 & 4 & 2.0 & 1 & 2 & 4 & 2.0 & 10 & 1860 & 2.3 & 167 & & \\
\hline 7 & 26 & 77.3 & 58.6 & 9.0 & 1 & 1 & 3 & 1.0 & 1 & 2 & 2 & 1.0 & 5 & 1953 & 1.2 & 380 & & \\
\hline 7 & 27 & 97.9 & 64.5 & 13.3 & i & 1 & 3 & 1.5 & 1 & 2 & 3 & 2.0 & 7 & 1900 & 1.0 & 550 & & \\
\hline 7 & 27 & 66.7 & 0.0 & 0.0 & 9 & 1 & 1 & 0.0 & 0 & 1 & 0 & 0.0 & & 1965 & 1.7 & & & \\
\hline 7 & 28 & 53.5 & 37.6 & 1.3 & 1 & $i$ & 3 & 1.0 & 1 & 2 & 3 & 1.0 & 5 & 1952 & 1.1 & 390 & & \\
\hline 7 & 29 & 94.3 & 112.8 & 106.0 & $i$ & $i$ & 4 & 1.0 & 1 & 2 & 4 & 1.0 & 8 & 1820 & 1.6 & 1370 & 1 & \\
\hline 7 & 30 & 192.6 & 149.2 & 201.4 & 1 & i & 5 & 2.0 & 1 & 2 & 3 & 2.5 & 6 & 1989 & 2.0 & 1400 & & \\
\hline 7 & 31 & 89.3 & 66.6 & 15.0 & 1 & 1 & 3 & 2.0 & 1 & 2 & 3 & 1.0 & 6 & 1984 & 0.9 & 319 & & \\
\hline 7 & $31 \mathrm{~A}$ & 53.4 & 52.9 & 5.2 & 1 & 1 & 2 & 1.5 & 1 & 1 & 1 & 1.0 & 5 & 1950 & 1.5 & 308 & & \\
\hline 7 & 32 & 19.4 & 89.0 & 54.7 & 1 & 1 & 3 & 1.0 & 1 & 3 & 3 & 1.0 & 4 & 1971 & 0.8 & 650 & & \\
\hline 7 & $32 A$ & 90.0 & 52.2 & 4.7 & 1 & 1 & 4 & 1.0 & 1 & 2 & 2. & 1.5 & 6 & 1780 & 1.2 & 853 & & \\
\hline 7 & 33 & 63.6 & 77.5 & 33.5 & 1 & $i$ & 3 & 1.5 & 1 & 2 & 3 & 1.0 & 6 & 1939 & 0.8 & 666 & & \\
\hline 7 & $33 \mathrm{~A}$ & 79.0 & 52.5 & 4.9 & 1 & 1 & 4 & 1.0 & 1 & 2 & 3 & 1.0 & 5 & 1986 & 0.9 & 300 & & \\
\hline 7 & 34 & 0.0 & 63.9 & 36.3 & 13 & 1 & & 0.0 & & & & 0.0 & & & 0.0 & 220 & 1 & \\
\hline 7 & 35 & 115.2 & 43.0 & 2.5 & 1 & $i$ & 4 & 2.0 & 1 & 2 & 3 & 2.0 & 5 & 1988 & 1.1 & 400 & & \\
\hline 7 & 36 & 63.9 & 55.9 & 15.0 & 1 & 1 & 3 & 1.0 & 1 & 2 & 3 & 1.0 & 4 & 1987 & 1.1 & 525 & 1 & \\
\hline 7 & 37 & 130.5 & 55.9 & 10.0 & $i$ & 1 & 4 & 2.0 & 1 & 2 & 4 & 3.0 & 8 & 1989 & 1.2 & 1300 & 1 & \\
\hline 7 & 38 & 80.7 & 56.2 & 7.4 & 1 & 1 & 3 & 2.0 & $i$ & 2 & 2 & 1.0 & 4 & 1983 & 0.7 & 400 & 1 & \\
\hline 7 & 39 & 0.0 & 46.1 & 6.0 & 13 & 1 & & 0.0 & & & & 0.0 & & & 0.0 & 450 & & \\
\hline 7 & 40 & 0.0 & 47.2 & 6.7 & 13 & 1 & & 0.0 & & & & 0.0 & & & 0.0 & 600 & 1 & \\
\hline 7 & 42 & 0.0 & 48.1 & 7.3 & 13 & 1 & & 0.0 & & & & 0.0 & & & 0.0 & 1110 & & \\
\hline 7 & 45 & 57.2 & 52.4 & 4.9 & 1 & 1 & 3 & 1.0 & 1 & 2 & 3 & 1.0 & 5 & 1970 & 1.0 & 300 & 1 & \\
\hline 7 & 46 & 0.0 & 13.6 & 7.0 & 13 & 1 & & 0.0 & & & & 0.0 & & & 0.0 & 116 & $i$ & \\
\hline 7 & 47 & 64.6 & 72.5 & 24.9 & 1 & $i$ & 3 & 1.0 & 1 & 2 & 3 & 1.0 & 6 & 1786 & 1.4 & 870 & $i$ & \\
\hline 7 & $47 \mathrm{~A}$ & 0.0 & 14.7 & 9.8 & 13 & 1 & & 0.0 & & & & 0.0 & & & 0.0 & 361 & & \\
\hline 7 & 48 & 1.1 & 53.1 & 10.9 & 13 & 1 & & 0.0 & & & & 0.0 & & & 0.0 & 450 & 1 & \\
\hline 7 & $48 \mathrm{~A}$ & 52.5 & 61.6 & 11.3 & 1 & 1 & 3 & 2.0 & 1 & 4 & 1 & 1.0 & 3 & 1976 & 0.7 & 444 & 1 & \\
\hline 7 & 49 & 87.3 & 65.0 & 13.7 & 1 & 1 & 3 & 1.0 & 1 & 2 & 3 & 1.5 & 6 & 1967 & 1.5 & 650 & 1 & \\
\hline 7 & 50 & 0.0 & 16.4 & 0.3 & 78 & 1 & & 0.0 & & & & 0.0 & & & 0.0 & 100 & & \\
\hline 7 & 51 & 9.7 & 49.3 & 3.9 & 1 & 1 & 1 & 1.0 & 1 & 1 & 0 & 0.0 & 2 & 1900 & 0.5 & 778 & & \\
\hline 7 & S1A & 55.9 & 61.4 & 12.6 & 1 & 1 & 2 & 1.0 & 1 & 2 & 3 & 1.0 & 6 & 1946 & 1.5 & 305 & 1 & \\
\hline 7 & 52 & 0.0 & 0.0 & 0.0 & 1 & 1 & 2 & 1.0 & 1 & 3 & 1 & 1.0 & 2 & 1800 & 0.9 & & & \\
\hline 7 & 52 & 100.1 & 36.7 & 1.0 & 1 & 1 & 3 & 1.0 & 1 & 2 & 2 & 1.0 & 4 & 1800 & 1.2 & 390 & & \\
\hline 7 & 53 & 88.7 & 95.9 & 68.5 & 1 & $i$ & 4 & 1.5 & 1 & 2 & 3 & 1.5 & 5 & 1942 & 1.3 & 3800 & 1 & \\
\hline 7 & $53 \mathrm{~A}$ & 0.0 & 89.6 & 71.5 & 13 & $i$ & & 0.0 & & & & 0.0 & & & 0.0 & & & \\
\hline 7 & 54 & 45.5 & 18.2 & 0.2 & 1 & 1 & 3 & 1.0 & 1 & 2 & 2 & 1.5 & 4 & 1939 & 0.9 & 100 & & \\
\hline
\end{tabular}




\begin{tabular}{|c|c|c|c|c|c|c|c|c|c|c|c|c|c|c|c|c|c|c|}
\hline Map & Lot & $\begin{array}{l}\text { Bldg. } \\
\text { Value }\end{array}$ & $\begin{array}{l}\text { Land } \\
\text { Value }\end{array}$ & Acres & $\begin{array}{l}\text { Land } \\
\text { Use }\end{array}$ & Zoning & $\begin{array}{l}\text { Bldg. } \\
\text { Grade }\end{array}$ & $\begin{array}{l}\text { \# of } \\
\text { Stories }\end{array}$ & $\begin{array}{l}\text { Occu- } \\
\text { pancy }\end{array}$ & $\begin{array}{l}\text { Heat } \\
\text { Type }\end{array}$ & $\begin{array}{l}\text { of } \\
\text { Beds }\end{array}$ & $\begin{array}{l}\text { of } \\
\text { Baths }\end{array}$ & $\begin{array}{l}\text { Total } \\
\text { Rooms }\end{array}$ & $\begin{array}{l}\text { Year } \\
\text { Built }\end{array}$ & $\begin{array}{l}1 \mathrm{st} \\
\text { Floor }\end{array}$ & Frontage & $\begin{array}{l}\text { Wet- } \\
\text { lands }\end{array}$ & $\begin{array}{l}\text { Water- } \\
\text { shed }\end{array}$ \\
\hline 7 & 55 & 26.6 & 18.2 & 0.2 & 1 & 1 & 2 & 1.0 & 1 & 2 & 1 & 1.0 & 3 & 1939 & 0.5 & 100 & & \\
\hline 7 & 56 & 115.8 & 94.2 & 65.0 & 9 & 1 & 3 & 1.5 & 1 & 2 & 3 & 1.0 & 6 & 1930 & 0.9 & 1300 & 1 & \\
\hline 7 & 57 & 60.0 & 52.6 & 5.0 & 1 & 1 & 3 & 1.0 & 1 & 2 & 2 & 1.0 & 5 & 1967 & 1.0 & 350 & & \\
\hline 7 & 58 & 52.0 & 20.0 & 0.3 & 1 & 1 & 3 & 1.0 & 1 & 3 & 1 & 1.0 & 3 & 1935 & 0.7 & 50 & & \\
\hline 7 & 59 & 38.1 & 23.8 & 0.4 & 1 & 1 & 2 & 1.5 & $i$ & 2 & 4 & 1.0 & 6 & 1900 & 1.0 & 200 & & \\
\hline 7 & 60 & 36.1 & 37.6 & 1.3 & 1 & 1 & 2 & 2.0 & 1 & 3 & 4 & 1.0 & 6 & 1939 & 0.7 & 250 & & \\
\hline 7 & 61 & 43.9 & 31.8 & 0.7 & 1 & 1 & 3 & 1.0 & 1 & 1 & 0 & 2.0 & 1 & 1939 & 0.8 & 100 & & \\
\hline 7 & 62 & 70.0 & 37.6 & 1.3 & 1 & 1 & 3 & 1.5 & 1 & 2 & 3 & 1.0 & 3 & 1950 & 0.9 & 226 & & \\
\hline 7 & 63 & 0.0 & 67.3 & 30.5 & 13 & 1 & & 0.0 & & & & 0.0 & & & 0.0 & 74 & 1 & \\
\hline 7 & $63 \mathrm{~A}$ & 70.3 & 56.4 & 7.5 & 1 & 1 & 3 & 1.0 & 1 & 2 & 3 & 1.0 & 5 & 1970 & 1.1 & 460 & 1 & \\
\hline 7 & $63 B$ & 87.8 & 58.8 & 5.0 & 1 & 1 & 3 & 1.0 & 1 & 2 & 2 & 2.0 & 5 & 1980 & 1.4 & 300 & 1 & \\
\hline 7 & $64 A$ & 122.3 & 81.0 & 58.0 & 1 & 1 & 3 & 1.5 & 1 & 2 & 3 & 2.5 & 7 & 1800 & 2.1 & & & \\
\hline 7 & 65 & 43.2 & 39.6 & 36.7 & 1 & 1 & 3 & 1.0 & 1 & 2 & 3 & 1.0 & 6 & 1978 & 1.0 & 0 & & \\
\hline 7 & 66 & 112.8 & 61.2 & 11.0 & 1 & 1 & 3 & 1.0 & 1 & 2 & 2 & 2.5 & 6 & 1970 & 1.7 & 673 & & \\
\hline 7 & 67 & 70.1 & 31.0 & 0.5 & 1 & 1 & 3 & 1.0 & 1 & 2 & 3 & 1.0 & 4 & 1972 & 1.1 & 70 & & \\
\hline 7 & 68 & 108.3 & 54.1 & 6.0 & 1 & 1 & 3 & 1.0 & 1 & 2 & 3 & 2.0 & 5 & 1984 & 1.7 & 1000 & & \\
\hline 7 & 69 & 0.0 & 47.4 & 6.9 & 15 & 1 & & 0.0 & & & & 0.0 & & & 0.0 & 1255 & 1 & \\
\hline 7 & $69 \mathrm{~A}$ & 46.6 & 54.2 & 6.1 & 1 & 1 & 2 & 1.0 & 1 & 4 & 3 & 1.0 & 4 & 1986 & 1.2 & 680 & 1 & \\
\hline 7 & 70 & 65.9 & 37.9 & 1.5 & 1 & 1 & 3 & 1.0 & 1 & 2 & 3 & 1.0 & 5 & 1986 & 1.0 & 220 & & \\
\hline 7 & 71 & 0.0 & 4.0 & 0.3 & 13 & 1 & & 0.0 & & & & 0.0 & & & 0.0 & 200 & & \\
\hline 7 & 72 & 146.6 & 62.7 & 12.0 & 1 & 1 & 4 & 2.0 & 1 & 2 & 5 & 2.5 & 12 & 1904 & 1.7 & 3900 & 1 & \\
\hline 7 & 73 & 0.0 & 47.6 & 7.0 & 13 & 1 & & 0.0 & & & & 0.0 & & & 0.0 & 390 & & \\
\hline 7 & 74 & 0.0 & 0.0 & 0.0 & 1 & 1 & 3 & 1.0 & 0 & 1 & 0 & 0.0 & 1 & 1983 & 0.2 & & & \\
\hline 7 & 74 & 165.5 & 69.0 & 22.0 & 1 & 1 & 4 & 1.0 & 1 & 2 & 3 & 2.0 & 7 & 1790 & 1.9 & 1190 & 1 & \\
\hline 7 & 75 & 64.6 & 78.7 & 36.0 & 1 & 1 & 2 & 1.0 & 1 & 2 & 3 & 1.0 & 6 & 1800 & 1.0 & 304 & 1 & \\
\hline 7 & $75 \mathrm{~A}$ & 161.5 & 56.0 & 8.0 & 1 & 1 & 5 & 2.0 & 1 & 2 & 3 & 2.5 & 7 & 1975 & 1.3 & 1300 & 1 & \\
\hline 7 & $75 B$ & 85.3 & 52.6 & 5.0 & 1 & 1 & 3 & 1.5 & 1 & 2 & 3 & 2.0 & 5 & 1987 & 0.9 & 360 & 1 & \\
\hline 7 & 76 & 0.0 & 85.6 & 63.0 & 13 & 1 & & 0.0 & & & & 0.0 & & & 0.0 & 800 & 1 & \\
\hline 7 & $76 A$ & 0.0 & 7.5 & 5.0 & 15 & 1 & & 0.0 & & & & 0.0 & & & 0.0 & 0 & & \\
\hline 7 & 77 & 0.0 & 15.2 & 10.1 & 15 & 1 & & 0.0 & & & & 0.0 & & & 0.0 & 0 & 1 & \\
\hline 7 & 78 & 0.0 & 9.3 & 6.2 & 15 & 1 & & 0.0 & & & & 0.0 & & & 0.0 & 0 & 1 & \\
\hline 7 & 79 & 0.0 & 15.2 & 10.1 & 15 & 1 & & 0.0 & & & & 0.0 & & & 0.0 & 0 & 1 & \\
\hline 7 & 80 & 130.5 & 137.5 & 160.6 & 1 & 1 & 4 & 1.5 & 1 & 2 & 3 & 2.0 & 6 & 1984 & 1.1 & 3000 & 1 & \\
\hline 7 & 82 & 60.9 & 59.8 & 10.0 & 1 & 1 & 3 & 1.0 & 1 & 2 & 4 & 1.0 & 6 & 1920 & 1.1 & 1210 & & \\
\hline 7 & $82 \mathrm{~A}$ & 80.6 & 53.4 & 5.5 & 1 & 1 & 3 & 1.0 & 1 & 2 & 3. & 1.5 & 6 & 1973 & 1.2 & 315 & & \\
\hline 7 & $82 B$ & 1.8 & 44.9 & 5.2 & 13 & 1 & & 0.0 & & & & 0.0 & & & 0.0 & 1250 & & \\
\hline 7 & $82 C$ & 0.0 & 71.7 & 38.0 & 13 & 1 & & 0.0 & & & & 0.0 & & & 0.0 & & & \\
\hline 7 & 83 & 0.0 & 45.4 & 8.0 & 13 & 1 & & 0.0 & & & & 0.0 & & & 0.0 & 550 & & \\
\hline 8 & 1 & 0.8 & 61.9 & 20.8 & 11 & 1 & & 0.0 & & & & 0.0 & & & 0.0 & 324 & 1 & \\
\hline 8 & 2 & 0.0 & 60.2 & 18.0 & 13 & 1 & & 0.0 & & & & 0.0 & & & 0.0 & 150 & 1 & \\
\hline
\end{tabular}




\begin{tabular}{|c|c|c|c|c|c|c|c|c|c|c|c|c|c|c|c|c|c|c|}
\hline Map & Lot & $\begin{array}{l}\text { Bldg. } \\
\text { Value }\end{array}$ & $\begin{array}{l}\text { Land } \\
\text { Value }\end{array}$ & Acres & $\begin{array}{l}\text { Land } \\
\text { Use }\end{array}$ & Zoning & $\begin{array}{l}\text { Bldg. } \\
\text { Grade }\end{array}$ & $\begin{array}{l}\text { " of } \\
\text { Stories }\end{array}$ & $\begin{array}{l}\text { Occu- } \\
\text { pancy }\end{array}$ & $\begin{array}{l}\text { Heat } \\
\text { Type }\end{array}$ & $\begin{array}{l}\text { \# of } \\
\text { Beds }\end{array}$ & $\begin{array}{l}\text { Wof } \\
\text { Baths }\end{array}$ & $\begin{array}{l}\text { Total } \\
\text { Rooms }\end{array}$ & $\begin{array}{l}\text { Year } \\
\text { Built }\end{array}$ & $\begin{array}{l}\text { 1st } \\
\text { Floor }\end{array}$ & Frontage & $\begin{array}{l}\text { Wet- } \\
\text { lands }\end{array}$ & $\begin{array}{l}\text { Water- } \\
\text { ahed }\end{array}$ \\
\hline 8 & 3 & 0.0 & 37.9 & 3.0 & 13 & 1 & & 0.0 & & & & 0.0 & & & 0.0 & 360 & & \\
\hline 8 & 4 & 0.0 & 67.4 & 31.0 & 13 & 1 & & 0.0 & & & & 0.0 & & & 0.0 & 775 & 1 & \\
\hline 8 & 5 & 183.9 & 71.3 & 22.8 & 1 & 1 & 7 & 2.0 & 1 & 2 & 3 & 2.0 & 8 & 1820 & 1.4 & 1125 & & \\
\hline 8 & 6 & 62.2 & 74.8 & 28.3 & 1 & 1 & 3 & 1.0 & 1 & 2 & 2 & 1.0 & 5 & 1939 & 1.0 & 620 & & 1 \\
\hline 8 & 7 & 0.0 & 52.6 & 10.6 & 13 & 1 & & 0.0 & & & & 0.0 & & & 0.0 & 457 & 1 & 1 \\
\hline 8 & 7B & 82.2 & 56.2 & 7.4 & 1 & 1 & 3 & 1.5 & 1 & 2 & 3 & 1.5 & 6 & 1968 & 1.6 & 456 & 1 & 1 \\
\hline 8 & $7 \mathrm{C}$ & 88.8 & 53.4 & 5.5 & 1 & 1 & 3 & 2.0 & 1 & 2 & 5 & 1.5 & 9 & 1974 & 1.1 & 325 & 1 & 1 \\
\hline 8 & 7D & 70.1 & 54.3 & 6.1 & 1 & 1 & 3 & 1.0 & 1 & 2 & 4 & 1.5 & 7 & 1970 & 1.0 & 400 & 1 & 1 \\
\hline 8 & $7 \mathrm{E}$ & 71.4 & 54.6 & 6.3 & 1 & 1 & 3 & 1.0 & 1 & 3 & 3 & 2.0 & 8 & 1986 & 1.0 & 1210 & & 1 \\
\hline 8 & $7 F$ & 91.7 & 53.0 & 7.0 & 1 & 1 & 3 & 1.0 & 1 & 2 & 3 & 1.0 & 2 & 1977 & 1.5 & 300 & 1 & 1 \\
\hline 8 & $7 \mathrm{G}$ & 67.2 & 53.6 & 5.7 & 1 & 1 & 3 & 1.0 & 1 & 2 & 3 & 1.0 & 5 & 1988 & 1.0 & 300 & 1 & 1 \\
\hline 8 & 8 & 72.6 & 52.9 & 5.2 & 1 & 1 & 3 & 1.0 & 1 & 2 & 2 & 2.0 & 5 & 1986 & 0.9 & 275 & 1 & 1 \\
\hline 8 & 9 & 9.7 & 123.2 & 142.8 & 9 & 1 & & 0.0 & & & & 0.0 & & & 0.0 & 4400 & 1 & 1 \\
\hline 8 & 10 & 68.3 & 68.9 & 14.0 & 6 & 1 & 4 & 1.0 & 1 & 2 & 2 & 1.0 & 6 & 1840 & 1.5 & 1700 & 1 & \\
\hline 8 & 12 & 169.2 & 77.0 & 40.0 & 1 & 1 & 4 & 1.5 & 1 & 1 & 5 & 1.0 & 10 & 1840 & 1.9 & 2700 & & 1 \\
\hline 8 & 13 & 0.0 & 64.1 & 26.0 & 13 & 1 & & 0.0 & & & & 0.0 & & & 0.0 & 2400 & 1 & 1 \\
\hline 8 & 15 & 31.8 & 91.6 & 60.7 & 1 & 1 & 3 & 1.0 & 1 & 1 & 2 & 1.0 & 4 & 1950 & 0.4 & 760 & & 1 \\
\hline 8 & $15 \mathrm{~A}$ & 23.7 & 59.0 & 16.0 & 12 & 1 & & 0.0 & & & & 0.0 & & & 0.0 & & & 1 \\
\hline 8 & 19 & 0.0 & 61.4 & 24.0 & 13 & 1 & & 0.0 & & & & 0.0 & & & 0.0 & 1150 & 1 & 1 \\
\hline 8 & 20 & 4.8 & 68.8 & 32.5 & 13 & 1 & & 0.0 & & & & 0.0 & & & 0.0 & 1200 & 1 & 1 \\
\hline 8 & $20 \mathrm{~A}$ & 0.0 & 44.0 & 4.6 & 13 & 1 & & 0.0 & & & & 0.0 & & & 0.0 & 250 & 1 & 1 \\
\hline 8 & $20 A 1$ & 105.4 & 53.0 & 5.2 & 1 & 1 & 4 & 2.0 & 1 & 2 & 3 & 2.0 & 6 & 1979 & 1.0 & 339 & 1 & 1 \\
\hline 8 & 21 & 63.3 & 43.8 & 2.9 & 1 & 1 & 3 & 1.0 & 1 & 2 & 3 & 1.5 & 6 & 1966 & 1.2 & 730 & & 1 \\
\hline 8 & 22 & 3.5 & 48.4 & 7.5 & 13 & 1 & & 0.0 & & & & 0.0 & & & 0.0 & 400 & & 1 \\
\hline 8 & $22 A$ & 109.6 & 52.5 & 5.5 & 1 & $i$ & 4 & 1.0 & 1 & 2 & 3 & 2.0 & 7 & 1979 & 1.2 & 339 & 1 & 1 \\
\hline 8 & $22 \mathrm{~A}$ & 0.0 & 0.0 & 0.0 & 1 & 1 & 1 & 1.0 & 1 & 4 & 2 & 1.0 & 5 & 1972 & 0.8 & & & 1 \\
\hline 8 & $22 B$ & 73.6 & 54.7 & 6.4 & 1 & 1 & 3 & 1.0 & 1 & 2 & 2 & 1.5 & 5 & 1973 & 1.1 & & & 1 \\
\hline 8 & $22 \mathrm{C}$ & 25.4 & 52.2 & 5.2 & 1 & 1 & 2 & 1.0 & 1 & 4 & 1 & 1.0 & 3 & 1900 & 0.6 & 365 & 1 & 1 \\
\hline 8 & $22 \mathrm{D}$ & 99.5 & 52.7 & 5.0 & 1 & 1 & 3 & 1.5 & 1 & 4 & 3 & 2.0 & 5 & 1977 & 1.1 & 300 & & 1 \\
\hline 8 & $22 \mathrm{E}$ & 96.0 & 52.9 & 5.2 & 1 & 1 & 3 & 1.0 & 1 & 2 & 3 & 1.0 & 6 & 1976 & 1.7 & 300 & & 1 \\
\hline 8 & $22 \mathrm{~F}$ & 94.3 & 56.1 & 7.3 & 1 & 1 & 3 & 1.5 & 1 & 3 & 3 & 2.0 & 6 & 1980 & 1.2 & 300 & & 1 \\
\hline 8 & 23 & 124.1 & 59.4 & 9.5 & 1 & 1 & 4 & 1.0 & 1 & 2 & 3 & 2.5 & 7 & 1959 & 1.8 & 663 & 1 & 1 \\
\hline 8 & 24 & 165.8 & 65.8 & 13.0 & 2 & $i$ & 4 & 2.0 & 5 & 2 & 5 & 5.0 & 13 & 1850 & 3.2 & 350 & 1 & 1 \\
\hline 8 & $24 A$ & 0.0 & 27.1 & 32.0 & 13 & 1 & & 0.0 & & & & 0.0 & & & 0.0 & 0 & 1 & 1 \\
\hline 8 & 25 & 0.0 & 8.4 & 5.6 & 13 & 1 & & 0.0 & & & & 0.0 & & & 0.0 & 0 & 1 & 1 \\
\hline 8 & 26 & 76.9 & 0.0 & 0.0 & 5 & 1 & & 0.0 & 1 & 3 & & 0.0 & & 1986 & 1.9 & & & 1 \\
\hline 8 & 26 & 128.4 & 69.6 & 30.0 & 1 & 1 & 5 & 1.5 & 1 & 2 & 3 & 2.5 & 10 & 1780 & 1.0 & 1600 & 1 & $i$ \\
\hline 8 & $26 A$ & 75.8 & 53.9 & 9.2 & 1 & 1 & 3 & 1.0 & 1 & 1 & 2 & 1.0 & 6 & 1987 & 1.0 & 475 & & 1 \\
\hline 8 & 27 & 98.4 & 52.6 & 5.0 & 1 & 1 & 4 & 2.0 & 1 & 2 & 3 & 2.0 & 7 & 1972 & 1.1 & & & 1 \\
\hline 8 & 28 & 83.9 & 37.9 & 1.5 & $i$ & $i$ & 4 & 1.0 & 1 & 2 & 3 & 1.5 & 5 & 1945 & 1.2 & 165 & & 1 \\
\hline
\end{tabular}




\begin{tabular}{|c|c|c|c|c|c|c|c|c|c|c|c|c|c|c|c|c|c|c|}
\hline Map & Lot & $\begin{array}{l}\text { Bldg. } \\
\text { Value }\end{array}$ & $\begin{array}{l}\text { Land } \\
\text { Value }\end{array}$ & Acres & $\begin{array}{l}\text { Land } \\
\text { Use }\end{array}$ & Zoning & $\begin{array}{l}\text { Bldg. } \\
\text { Grade }\end{array}$ & $\begin{array}{l}\text { " of } \\
\text { Stories }\end{array}$ & $\begin{array}{l}\text { Occu- } \\
\text { pancy }\end{array}$ & $\begin{array}{l}\text { Heat } \\
\text { Type }\end{array}$ & $\begin{array}{l}\text { Hof } \\
\text { Beds }\end{array}$ & $\begin{array}{l}\text { \# of } \\
\text { Baths }\end{array}$ & $\begin{array}{l}\text { Total } \\
\text { Rooms }\end{array}$ & $\begin{array}{l}\text { Year } \\
\text { Built }\end{array}$ & $\begin{array}{l}\text { 1st } \\
\text { Floor }\end{array}$ & Frontage & $\begin{array}{l}\text { Wet- } \\
\text { lands }\end{array}$ & $\begin{array}{l}\text { Water- } \\
\text { shed }\end{array}$ \\
\hline 8 & $28 \mathrm{~A}$ & 113.2 & 53.7 & 5.7 & 1 & 1 & 4 & 1.5 & 1 & 4 & 3 & 2.0 & 9 & 1979 & 1.4 & 475 & & 1 \\
\hline 8 & 28B & 97.3 & 52.7 & 5.1 & 1 & 1 & 4 & 2.0 & 1 & 4 & 2 & 2.0 & 7 & 1976 & 1.1 & 300 & & \\
\hline 8 & $28 \mathrm{C}$ & 106.2 & 52.3 & 4.8 & 1 & 1 & 3 & 1.0 & 1 & 2 & 4 & 2.5 & 7 & 1976 & 1.4 & 300 & & 1 \\
\hline 8 & 28D & 105.6 & 52.1 & 4.7 & 1 & 1 & 4 & 2.0 & 1 & 2 & 3 & 2.0 & 5 & 1977 & 1.1 & 300 & & \\
\hline 8 & $28 F$ & 0.0 & 57.0 & 13.7 & 13 & 1 & & 0.0 & & & & 0.0 & & & 0.0 & & & 1 \\
\hline 8 & 29 & 113.0 & 45.3 & 3.2 & 1 & 1 & 4 & 1.0 & 1 & 2 & 3 & 2.5 & 7 & 1967 & 1.6 & 301 & 1 & 1 \\
\hline 8 & 30 & 82.8 & 52.2 & 4.7 & 1 & 1 & 3 & 2.0 & 1 & 2 & 3 & 1.0 & 6 & 1968 & 0.9 & 500 & 1 & 1 \\
\hline 8 & 31 & 131.8 & 66.6 & 15.0 & 1 & 1 & 4 & 2.0 & 1 & 2 & 4 & 2.5 & 8 & 1987 & 1.1 & 230 & & \\
\hline 8 & 32 & 99.8 & 52.6 & 5.0 & 1 & 1 & 3 & 2.0 & 1 & 2 & 2 & 1.5 & 5 & 1979 & 1.5 & 180 & & \\
\hline 8 & 33 & 96.9 & 39.9 & 1.9 & 1 & 1 & 3 & 1.0 & 1 & 2 & 4 & 2.0 & 9 & 1700 & 1.3 & 300 & 1 & \\
\hline 8 & 34 & 106.6 & 59.4 & 9.5 & 1 & 1 & 4 & 1.5 & 1 & 2 & 5 & 2.0 & 1 & 1749 & 1.5 & 364 & 1 & \\
\hline 8 & $34 \mathrm{~A}$ & 122.0 & 67.3 & 16.5 & 1 & 1 & 4 & 1.5 & 1 & 4 & 4 & 2.5 & 8 & 1974 & 1.1 & 540 & & \\
\hline 8 & 34B & 75.7 & 54.1 & 6.0 & 1 & 1 & 3 & 1.0 & 1 & 2 & 3 & 1.0 & 6 & 1975 & 1.1 & 300 & & \\
\hline 8 & 35 & 82.0 & 40.1 & 2.0 & 1 & 1 & 2 & 1.0 & 1 & 2 & 2 & 1.0 & 6 & 1920 & 0.9 & 250 & 1 & \\
\hline 8 & 36 & 0.0 & 69.1 & 33.0 & 13 & 1 & & 0.0 & & & & 0.0 & & & 0.0 & 50 & 1 & \\
\hline 8 & 37 & 0.0 & 10.5 & 4.0 & 15 & 1 & & 0.0 & & & & 0.0 & & & 0.0 & 400 & $i$ & \\
\hline 8 & 38 & 87.0 & 53.8 & 9.0 & 1 & $i$ & 3 & 1.0 & 1 & 2 & 2 & 2.5 & 5 & 1977 & 1.7 & 300 & 1 & \\
\hline 8 & 40 & 113.3 & 52.1 & 4.7 & 1 & 1 & 3 & 1.0 & 1 & 2 & 2 & 2.5 & 5 & 1970 & 1.8 & 500 & 1 & 1 \\
\hline 8 & $40 \mathrm{~A}$ & 82.1 & 52.5 & 4.9 & 1 & 1 & 4 & 1.0 & 1 & 2 & 2 & 1.0 & 4 & 1986 & 1.1 & 300 & & 1 \\
\hline 8 & $40 \mathrm{~B}$ & 112.0 & 56.4 & 7.5 & 1 & 1 & 3 & 1.0 & 2 & 2 & 2 & 3.0 & 5 & 1981 & 1.2 & 582 & & 1 \\
\hline 8 & $40 C$ & 78.8 & 52.3 & 4.8 & 1 & 1 & 4 & 1.0 & 1 & 2 & 1 & 1.0 & 4 & 1983 & 0.9 & 350 & 1 & 1 \\
\hline 8 & 42 & 83.3 & 41.1 & 2.3 & 1 & 1 & 3 & 1.0 & 1 & 2 & 3 & 2.0 & 6 & 1972 & 1.5 & 400 & & 1 \\
\hline 8 & 43 & 97.7 & 54.9 & 6.5 & 1 & 1 & 3 & 1.0 & 1 & 2 & 4 & 2.0 & 9 & 1975 & 1.5 & 200 & & 1 \\
\hline 8 & 44 & 69.6 & 52.1 & 4.6 & 1 & 1 & 3 & 1.0 & 1 & 2 & 3 & 1.0 & 7 & 1959 & 1.3 & 400 & & 1 \\
\hline 8 & 45 & 5.5 & 40.2 & 2.1 & 1 & 1 & & 0.0 & & & & 0.0 & & & 0.0 & 265 & & 1 \\
\hline 8 & 46 & 80.6 & 56.1 & 7.3 & 1 & 1 & 4 & 1.0 & 1 & 2 & 2 & 1.0 & 4 & 1965 & 0.9 & 509 & & 1 \\
\hline 8 & $46 \mathrm{~A}$ & 83.8 & 53.1 & 5.3 & 1 & 1 & 5 & 1.5 & 1 & 4 & 2 & 2.0 & 5 & 1988 & 0.9 & 300 & & 1 \\
\hline 8 & 47 & 78.8 & 47.2 & 3.6 & 1 & 1 & 3 & 1.0 & 1 & 2 & 3 & 1.0 & 6 & 1961 & 1.4 & 400 & & $i$ \\
\hline 8 & 48 & 67.8 & 64.3 & 56.3 & 12 & 1 & 2 & 0.0 & & & & 0.0 & & 1969 & 3.1 & 2200 & 1 & \\
\hline 8 & $48 \mathrm{~A}$ & 82.9 & 53.4 & 5.5 & 1 & 1 & 3 & 1.0 & 1 & 2 & 3 & 1.0 & 6 & 1981 & 1.3 & 300 & & 1 \\
\hline 8 & 49 & 0.0 & 51.1 & 36.0 & 15 & 1 & & 0.0 & & & & 0.0 & & & 0.0 & 2000 & 1 & \\
\hline 8 & 50 & 74.9 & 50.0 & 4.3 & 1 & 1 & 3 & 1.5 & 1 & 2 & 4 & 2.0 & 9 & 1750 & 1.3 & 980 & & 1 \\
\hline 8 & 51 & 99.5 & 52.6 & 5.0 & 1 & 1 & 4 & 1.5 & 1 & 2 & 3 & 2.0 & 10 & 1816 & 1.6 & 340 & 1 & 1 \\
\hline 8 & $51 \mathrm{~A}$ & 103.2 & 52.4 & 4.9 & 1 & 1 & 4 & 2.0 & 1 & 2 & 4 & 2.0 & 8 & 1987 & 0.8 & 650 & & 1 \\
\hline 8 & $51 \mathrm{~A} 1$ & 89.5 & 52.4 & 4.9 & 1 & 1 & 4 & 1.5 & 1 & 4 & 3 & 1.5 & 6 & 1979 & 1.0 & & & 1 \\
\hline 8 & 52 & 0.0 & 52.2 & 10.3 & 13 & 1 & & 0.0 & & & & 0.0 & & & 0.0 & 550 & & 1 \\
\hline 8 & $52 \mathrm{~A}$ & 0.0 & 73.1 & 41.7 & 13 & 1 & & 0.0 & & & & 0.0 & & & 0.0 & 900 & 1 & 1 \\
\hline 8 & 53 & 63.1 & 75.0 & 29.5 & 1 & 1 & 3 & 1.0 & 1 & 2 & 2 & 1.0 & 5 & 1959 & 1.1 & 450 & & 1 \\
\hline 8 & $53 \mathrm{~A}$ & 0.0 & 54.0 & 11.5 & 13 & 1 & & 0.0 & & & & 0.0 & & & 0.0 & 700 & & 1 \\
\hline 8 & $53 \mathrm{~B}$ & 76.6 & 52.2 & 4.8 & 1 & 1 & 3 & 1.5 & 1 & 2 & 2 & 2.0 & 6 & 1980 & 0.9 & 400 & & 1 \\
\hline
\end{tabular}




\begin{tabular}{|c|c|c|c|c|c|c|c|c|c|c|c|c|c|c|c|c|c|c|}
\hline Map & Lot & $\begin{array}{l}\text { Bldg. } \\
\text { Value }\end{array}$ & $\begin{array}{l}\text { Land } \\
\text { Value }\end{array}$ & Acres & $\begin{array}{l}\text { Land } \\
\text { Use }\end{array}$ & Zoning & $\begin{array}{l}\text { Bldg. } \\
\text { Grade }\end{array}$ & $\begin{array}{l}\text { \# of } \\
\text { Stories }\end{array}$ & $\begin{array}{l}\text { Occu- } \\
\text { pancy }\end{array}$ & $\begin{array}{l}\text { Heat } \\
\text { Type }\end{array}$ & $\begin{array}{l}\text { " of } \\
\text { Beds }\end{array}$ & $\begin{array}{l}\text { " of } \\
\text { Baths }\end{array}$ & $\begin{array}{l}\text { Total } \\
\text { Rooms }\end{array}$ & $\begin{array}{l}\text { Year } \\
\text { Built }\end{array}$ & $\begin{array}{l}1 \mathrm{st} \\
\text { Floor }\end{array}$ & Frontage & $\begin{array}{l}\text { Wet- } \\
\text { lands }\end{array}$ & $\begin{array}{l}\text { Water- } \\
\text { shed }\end{array}$ \\
\hline 8 & $53 \mathrm{C}$ & 0.0 & 52.1 & 10.0 & 13 & 1 & & 0.0 & & & & 0.0 & & & 0.0 & 300 & & 1 \\
\hline 8 & 54 & 0.0 & 87.5 & 68.0 & 13 & 1 & & 0.0 & & & & 0.0 & & & 0.0 & 1100 & & \\
\hline 8 & 55 & 7.9 & 96.8 & 104.0 & 13 & 1 & & 0.0 & & & & 0.0 & & & 0.0 & 1320 & & \\
\hline 8 & 56 & 0.0 & 7.9 & 2.0 & 13 & 1 & & 0.0 & & & & 0.0 & & & 0.0 & 100 & & \\
\hline 8 & 57 & 0.0 & 47.3 & 6.8 & 13 & 1 & & 0.0 & & & & 0.0 & & & 0.0 & 800 & & \\
\hline 8 & 57A & 0.0 & 49.7 & 8.4 & 13 & 1 & & 0.0 & & & & 0.0 & & & 0.0 & & & \\
\hline 8 & 57B & 0.0 & 44.1 & 6.8 & 13 & 1 & & 0.0 & & & & 0.0 & & & 0.0 & & & \\
\hline 8 & 58 & 73.8 & 42.2 & 2.4 & 1 & 1 & 3 & 1.0 & 1 & 3 & 3 & 2.0 & 5 & 1989 & 1.0 & 300 & & \\
\hline 8 & 60 & 72.2 & 38.3 & 1.6 & 1 & 1 & 3 & 2.0 & 1 & 2 & 3 & 1.5 & 7 & 1930 & 0.8 & 400 & & \\
\hline 8 & 61 & 1.5 & 11.8 & 0.1 & 1 & 1 & & 0.0 & & & & 0.0 & & & 0.0 & 40 & & 1 \\
\hline 8 & 64 & 67.7 & 52.6 & 5.0 & 1 & 1 & 3 & 2.0 & 2 & 2 & 2 & 2.0 & 6 & 1939 & 0.8 & 500 & & \\
\hline 8 & 65 & 0.0 & 46.1 & 6.0 & 13 & 1 & & 0.0 & & & & 0.0 & & & 0.0 & 355 & & \\
\hline 8 & $65 \mathrm{~A}$ & 0.0 & 46.1 & 6.0 & 13 & 1 & & 0.0 & & & & 0.0 & & & 0.0 & 355 & & \\
\hline 8 & 66 & 33.5 & 36.6 & 1.0 & 1 & 1 & 2 & 1.0 & 1 & 3 & 3 & 1.0 & 4 & 1946 & 0.9 & 214 & & \\
\hline 9 & 1 & 38.0 & 74.4 & 28.0 & 1 & 1 & 2 & 1.0 & $i$ & 3 & 1 & 1.0 & 4 & 1956 & 0.6 & 187 & & 1 \\
\hline 9 & 2 & 63.8 & 38.5 & 1.6 & 1 & 1 & 3 & 1.0 & 1 & 2 & 4 & 1.0 & 6 & 1956 & 1.2 & 150 & & 1 \\
\hline 9 & 3 & 0.0 & 56.0 & 13.0 & 13 & 1 & & 0.0 & & & & 0.0 & & & 0.0 & 350 & 1 & 1 \\
\hline 9 & $3 \mathrm{~A}$ & 56.8 & 52.6 & 5.0 & 1 & 1 & 3 & 1.5 & 1 & 2 & 3 & 1.0 & 6 & 1900 & 0.7 & 300 & & $i$ \\
\hline 9 & 4 & 72.5 & 48.8 & 4.0 & 1 & 1 & 3 & 1.0 & 1 & 2 & 3 & 1.0 & 5 & 1970 & 1.1 & 300 & & 1 \\
\hline 9 & $4 A$ & 101.0 & 52.5 & 4.9 & $i$ & 1 & 4 & 1.5 & 1 & 2 & 3 & 2.0 & 8 & 1974 & 1.2 & 300 & & 1 \\
\hline 9 & $5 A$ & 60.3 & 52.6 & 5.0 & 1 & 1 & 3 & 1.0 & 1 & 3 & 1 & 1.0 & 4 & 1986 & 0.8 & 300 & & 1 \\
\hline 9 & $5 B$ & 102.4 & 52.6 & 5.0 & 1 & 1 & 3 & 1.5 & 1 & 3 & 3 & 2.0 & 7 & 1984 & 1.4 & 300 & & 1 \\
\hline 9 & 6 & 92.7 & 130.7 & 143.2 & 1 & 1 & 5 & 1.5 & 1 & 2 & 2 & 1.0 & 7 & 1785 & 1.1 & 1400 & 1 & 1 \\
\hline 9 & 7 & 101.5 & 40.4 & 2.1 & 1 & 1 & 5 & 2.0 & 1 & 2 & 3 & 1.5 & 8 & 1928 & 0.8 & 476 & & 1 \\
\hline 9 & 8 & 132.4 & 72.2 & 27.5 & 1 & 1 & 4 & 2.0 & 1 & 2 & 3 & 2.5 & 7 & 1989 & 1.2 & 405 & & 1 \\
\hline 9 & $8 \mathrm{~A}$ & 0.0 & 50.6 & 9.0 & 13 & 1 & & 0.0 & & & & 0.0 & & & 0.0 & 461 & & 1 \\
\hline 9 & $8 B$ & 0.0 & 59.2 & 16.3 & 13 & 1 & & 0.0 & & & & 0.0 & & & 0.0 & 303 & & 1 \\
\hline 9 & $8 \mathrm{C}$ & 83.5 & 67.0 & 16.1 & 1 & 1 & 3 & 1.0 & 1 & 2 & 3 & 2.0 & 7 & 1976 & 1.5 & 303 & & 1 \\
\hline 9 & 9 & 58.4 & 54.1 & 6.0 & 1 & 1 & 3 & 1.5 & 1 & 2 & 3 & 1.0 & 7 & 1900 & 1.1 & 500 & & 1 \\
\hline 9 & 10 & 66.0 & 37.8 & 1.4 & 1 & 1 & 3 & 1.0 & 1 & 2 & 3 & 1.0 & 5 & 1963 & 0.9 & 72 & & 1 \\
\hline 9 & 11 & 0.0 & 45.0 & 5.3 & 13 & 1 & & 0.0 & & & & 0.0 & & & 0.0 & 300 & & 1 \\
\hline 9 & $11 \mathrm{~A}$ & 85.6 & 54.7 & 6.4 & 1 & 1 & 3 & 2.0 & 1 & 2 & 3 & 1.5 & 8 & 1974 & 1.0 & 329 & & 1 \\
\hline 9 & $11 \mathrm{~B}$ & 127.2 & 54.1 & 6.0 & 1 & 1 & 5 & 2.0 & 1 & 2 & 3 & 1.5 & 6 & 1983 & 1.0 & 463 & & 1 \\
\hline 9 & $11 \mathrm{~B} 1$ & 0.0 & 45.1 & 5.3 & 13 & 1 & & 0.0 & & & & 0.0 & & & 0.0 & 458 & & 1 \\
\hline 9 & 12 & 57.5 & 67.0 & 16.0 & 1 & 1 & 3 & 1.5 & 1 & 2 & 1 & 1.0 & 5 & 1930 & 0.7 & 396 & & 1 \\
\hline 9 & 14 & 101.5 & 85.7 & 71.6 & 2 & 1 & 5 & 1.0 & 2 & 2 & 5 & 2.0 & 14 & 1880 & 1.9 & 355 & & 1 \\
\hline 9 & $14 \mathrm{~A}$ & 0.0 & 10.1 & 4.7 & 15 & 1 & & 0.0 & & & & 0.0 & & & 0.0 & 237 & & $i$ \\
\hline 9 & 15 & 69.6 & 66.9 & 15.5 & 1 & 1 & 3 & 1.0 & 1 & 2 & 2 & 1.0 & 5 & 1930 & 1.1 & 50 & & 1 \\
\hline 9 & 16 & 91.9 & 52.6 & 5.0 & $i$ & 1 & 5 & 1.0 & 1 & 2 & 1 & 2.0 & 4 & 1985 & 1.0 & 385 & & 1 \\
\hline 9 & 17 & 95.1 & 54.9 & 6.5 & 1 & $i$ & 6 & 1.0 & 1 & 2 & 1 & 1.0 & 6 & 1790 & 1.2 & 400 & 1 & 1 \\
\hline
\end{tabular}




\begin{tabular}{|c|c|c|c|c|c|c|c|c|c|c|c|c|c|c|c|c|c|c|}
\hline Map & Lot & $\begin{array}{l}\text { Bldg. } \\
\text { Value }\end{array}$ & $\begin{array}{l}\text { Land } \\
\text { Value }\end{array}$ & Acres & $\begin{array}{l}\text { Land } \\
\text { Use }\end{array}$ & Zoning & $\begin{array}{l}\text { Bldg. } \\
\text { Grade }\end{array}$ & $\begin{array}{l}\text { of } \\
\text { Stories }\end{array}$ & $\begin{array}{l}\text { Occu- } \\
\text { pancy }\end{array}$ & $\begin{array}{l}\text { Heat } \\
\text { Type }\end{array}$ & $\begin{array}{l}\text { \# of } \\
\text { Beds }\end{array}$ & $\begin{array}{l}\text { \# of } \\
\text { Baths }\end{array}$ & $\begin{array}{l}\text { Total } \\
\text { Rooms }\end{array}$ & $\begin{array}{l}\text { Year } \\
\text { Built }\end{array}$ & $\begin{array}{l}\text { 1st } \\
\text { Floor }\end{array}$ & Frontage & $\begin{array}{l}\text { Wet- } \\
\text { lands }\end{array}$ & $\begin{array}{l}\text { Water- } \\
\text { shed }\end{array}$ \\
\hline 9 & $17 \mathrm{~A}$ & 91.1 & 57.6 & 8.3 & 1 & 1 & 4 & 2.0 & 1 & 2 & 3 & 1.5 & 6 & 1976 & 0.9 & 531 & 1 & 1 \\
\hline 9 & 17B & 101.1 & 57.1 & 8.0 & 1 & 1 & 4 & 1.5 & 1 & 2 & 3 & 2.0 & 6 & 1975 & 1.1 & 300 & 1 & 1 \\
\hline 9 & $17 C$ & 125.3 & 54.3 & 6.1 & 1 & 1 & 4 & 2.0 & 1 & 2 & 3 & 2.0 & 8 & 1976 & 1.6 & 300 & 1 & 1 \\
\hline 9 & 17D & 0.0 & 60.4 & 18.3 & 13 & 1 & & 0.0 & & & & 0.0 & & & 0.0 & 1080 & 1 & 1 \\
\hline 9 & $17 F$ & 132.6 & 52.6 & 5.0 & 1 & 1 & 5 & 1.5 & 1 & 2 & 3 & 2.0 & 7 & 1989 & 1.2 & 320 & 1 & 1 \\
\hline 9 & $17 \mathrm{G}$ & 120.5 & 54.0 & 5.9 & 1 & 1 & 4 & 2.0 & 1 & 2 & 3 & 2.5 & 8 & 1978 & 1.1 & 326 & 1 & 1 \\
\hline 9 & 18 & 82.1 & 60.8 & 10.7 & 1 & 1 & 3 & 1.0 & $i$ & 2 & 3 & 1.0 & 5 & 1977 & 1.2 & 349 & 1 & 1 \\
\hline 9 & $18 \mathrm{~A}$ & 0.0 & 11.4 & 7.6 & 13 & 1 & & 0.0 & & & & 0.0 & & & 0.0 & & & 1 \\
\hline 9 & 19 & 81.5 & 38.8 & 1.7 & 1 & 1 & 3 & 1.5 & 1 & 2 & 4 & 1.5 & 6 & 1930 & 0.9 & 247 & & 1 \\
\hline 9 & 20 & 147.6 & 79.2 & 40.0 & 1 & 1 & 6 & 1.0 & 1 & 2 & 5 & 2.0 & 10 & 1770 & 1.7 & 1400 & 1 & 1 \\
\hline 9 & 21 & 72.0 & 71.6 & 25.0 & 1 & 1 & 3 & 1.0 & 1 & 2 & 4 & 1.0 & 7 & 1860 & 1.3 & 700 & & 1 \\
\hline 9 & 22 & 165.5 & 40.1 & 2.0 & 1 & 1 & 6 & 2.0 & 1 & 2 & 5 & 3.0 & 12 & 1880 & 1.6 & 625 & & 1 \\
\hline 9 & 23 & 66.4 & 27.9 & 0.5 & 1 & 1 & 3 & 1.0 & $i$ & 2 & 3 & 1.5 & 5 & 1968 & 1.1 & 100 & & $i$ \\
\hline 9 & 24 & 0.0 & 63.9 & 24.0 & 13 & 1 & & 0.0 & & & & 0.0 & & & 0.0 & 2000 & 1 & 1 \\
\hline 9 & 25 & 74.3 & 79.0 & 36.5 & 1 & 1 & 3 & 1.5 & 1 & 4 & 2 & 2.0 & 5 & 1983 & 0.9 & 0 & & 1 \\
\hline 9 & 26 & 143.4 & 71.1 & 26.0 & 1 & 1 & 6 & 1.5 & 1 & 2 & 3 & 2.5 & 8 & 1730 & 1.7 & 405 & 1 & 1 \\
\hline 9 & 27 & 0.0 & 2058.0 & 196.0 & 10 & 1 & & 0.0 & & & & 0.0 & & & 0.0 & 3800 & 1 & 1 \\
\hline 9 & 28 & 111.1 & 37.9 & 1.5 & 1 & 1 & 5 & 1.5 & 1 & 2 & 3 & 2.0 & 7 & 1978 & 1.4 & 250 & & 1 \\
\hline 9 & 29 & 76.6 & 101.1 & 82.0 & 1 & 1 & 5 & 1.0 & 1 & 2 & 2 & 1.5 & 7 & 1800 & 1.1 & 2400 & 1 & 1 \\
\hline 9 & 30 & 102.7 & 86.8 & 50.8 & 1 & 1 & 4 & 2.0 & 1 & 2 & 4 & 2.0 & 8 & 1800 & 1.1 & 0 & 1 & 1 \\
\hline 9 & $30 \mathrm{~B}$ & 0.0 & 9.7 & 1.6 & 10 & 1 & & 0.0 & & & & 0.0 & & & 0.0 & & & 1 \\
\hline 9 & $30 \mathrm{C}$ & 0.0 & 21.3 & 3.6 & 10 & 1 & & 0.0 & & & & 0.0 & & & 0.0 & & & 1 \\
\hline 9 & 31 & 50.6 & 55.0 & 6.6 & 1 & 1 & 2 & 1.0 & 1 & 1 & 2 & 1.0 & 5 & 1970 & 1.0 & 492 & & 1 \\
\hline 9 & $32 \mathrm{~A}$ & 0.0 & 2.9 & 0.5 & 10 & 1 & & 0.0 & & & & 0.0 & & & 0.0 & & & 1 \\
\hline 9 & $32 B$ & 0.0 & 74.2 & 42.5 & 13 & $i$ & & 0.0 & & & & 0.0 & & & 0.0 & 36 & 1 & 1 \\
\hline 9 & $32 \mathrm{C}$ & 56.7 & 54.2 & 6.0 & 1 & 1 & 2 & 1.0 & 1 & 1 & 3 & 1.0 & 3 & 1983 & 0.9 & 300 & & 1 \\
\hline 9 & 32D & 101.5 & 58.8 & 9.2 & 1 & 1 & 3 & 1.0 & 1 & 2 & 4 & 2.0 & 7 & 1978 & 1.8 & 418 & & 1 \\
\hline 9 & 33 & 0.0 & 113.6 & 121.7 & 13 & 1 & & 0.0 & & & & 0.0 & & & 0.0 & 243 & & 1 \\
\hline 9 & $33 \mathrm{~A}$ & 0.0 & 149.4 & 0.0 & 10 & 1 & & 0.0 & & & & 0.0 & & & 0.0 & & & 1 \\
\hline 9 & 34 & 46.1 & 0.0 & 0.0 & 7 & 1 & 1 & 0.0 & & 2 & & 0.0 & & 1950 & 4.0 & & & 1 \\
\hline 9 & 34 & 85.4 & 143.7 & 68.0 & 1 & i & 3 & 1.0 & 1 & 2 & 3 & 1.0 & 5 & 1944 & 0.8 & 0 & & 1 \\
\hline 9 & 34 & 0.0 & 0.0 & 0.0 & 1 & 1 & 2 & 1.0 & 1 & 2 & 2 & 1.0 & 6 & 1940 & 0.6 & & & 1 \\
\hline 9 & 35 & 0.0 & 10332. & 984.0 & 10 & 1 & & 0.0 & & & & 0.0 & & & 0.0 & 2850 & 1 & 1 \\
\hline 9 & 36 & 0.0 & 48.8 & 7.8 & 13 & 1 & & 0.0 & & & & 0.0 & & & 0.0 & 50 & & 1 \\
\hline 9 & $36 \mathrm{~A}$ & 85.1 & 53.8 & 5.8 & 1 & $i$ & 3 & 2.0 & 1 & 2 & 3 & 2.0 & 6 & 1900 & 1.1 & 550 & 1 & 1 \\
\hline 9 & 37 & 77.2 & 53.0 & 5.2 & 1 & 1 & 3 & 1.5 & 1 & 2 & 4 & 1.0 & 6 & 1939 & 1.2 & 483 & & 1 \\
\hline 9 & $37 A$ & 0.0 & 44.6 & 5.0 & 13 & 1 & & 0.0 & & & & 0.0 & & & 0.0 & 293 & & 1 \\
\hline 9 & $37 \mathrm{~B}$ & 0.0 & 47.7 & 7.1 & 13 & $i$ & & 0.0 & & & & 0.0 & & & 0.0 & 300 & & 1 \\
\hline 9 & $37 \mathrm{~B} 1$ & 130.7 & 54.6 & 6.4 & 1 & 1 & 5 & 2.0 & 1 & 2 & 3 & 2.5 & 7 & 1986 & 0.9 & 305 & & 1 \\
\hline 9 & 37B2 & 142.7 & 54.2 & 6.0 & 1 & 1 & 5 & 2.0 & 1 & 2 & 4 & 2.5 & 8 & 1987 & 1.2 & 395 & & 1 \\
\hline
\end{tabular}




\begin{tabular}{|c|c|c|c|c|c|c|c|c|c|c|c|c|c|c|c|c|c|c|}
\hline Map & Lot & $\begin{array}{l}\text { Bldg. } \\
\text { Value }\end{array}$ & $\begin{array}{l}\text { Land } \\
\text { Value }\end{array}$ & Acres & $\begin{array}{l}\text { Land } \\
\text { Use }\end{array}$ & Zoning & $\begin{array}{l}\text { Bldg. } \\
\text { Grade }\end{array}$ & $\begin{array}{l}\text { \# of } \\
\text { Stories }\end{array}$ & $\begin{array}{l}\text { Occu- } \\
\text { pancy }\end{array}$ & $\begin{array}{l}\text { Heat } \\
\text { Type }\end{array}$ & $\begin{array}{l}\text { \# of } \\
\text { Beds }\end{array}$ & $\begin{array}{l}\text { \# of } \\
\text { Baths }\end{array}$ & $\begin{array}{l}\text { Total } \\
\text { Rooms }\end{array}$ & $\begin{array}{l}\text { Year } \\
\text { Built }\end{array}$ & $\begin{array}{l}\text { 1st } \\
\text { Floor }\end{array}$ & Frontage & $\begin{array}{l}\text { Wet- } \\
\text { lands }\end{array}$ & $\begin{array}{l}\text { Water- } \\
\text { shed }\end{array}$ \\
\hline 10 & 1 & 55.9 & 36.3 & 1.0 & 1 & 1 & 3 & 1.0 & 1 & 2 & 3 & 1.0 & 5 & 1967 & 0.9 & 660 & & \\
\hline 10 & 2 & 82.5 & 42.5 & 2.5 & 1 & 1 & 3 & 1.5 & 1 & 3 & 3 & 3.0 & 5 & 1949 & 1.4 & 543 & & \\
\hline 10 & 4 & 64.3 & 29.4 & 0.3 & 1 & 1 & 3 & 1.0 & 1 & 3 & 3 & 1.0 & 5 & 1968 & 1.0 & 281 & & \\
\hline 10 & 5 & 0.0 & 2.3 & 0.2 & 13 & 1 & & 0.0 & & & & 0.0 & & & 0.0 & 101 & & \\
\hline 10 & 6 & 2.7 & 17.0 & 0.2 & 1 & 1 & 1 & 1.0 & 1 & 1 & 1 & 1.0 & 2 & 1950 & 0.8 & 267 & & \\
\hline 10 & 7 & 0.0 & 16.7 & 0.4 & 13 & 1 & & 0.0 & & & & 0.0 & & & 0.0 & 122 & & \\
\hline 10 & 8 & 0.0 & 5.5 & 0.5 & 13 & 4 & & 0.0 & & & & 0.0 & & & 0.0 & 250 & & \\
\hline 10 & 9 & 0.0 & 11.5 & 0.5 & 14 & 4 & & 0.0 & & & & 0.0 & & & 0.0 & 160 & & \\
\hline 10 & $9 A$ & 0.0 & 0.5 & 0.1 & 13 & 4 & & 0.0 & & & & 0.0 & & & 0.0 & 600 & & \\
\hline 10 & 10 & 63.7 & 64.0 & 12.5 & 1 & 1 & 3 & 1.0 & 1 & 2 & 2 & 1.0 & 6 & 1865 & 1.0 & 222 & & \\
\hline 10 & 11 & 106.7 & 68.1 & 20.0 & 1 & 1 & 4 & 1.0 & 1 & 2 & 1 & 1.0 & 4 & 1977 & 1.4 & 434 & & \\
\hline 10 & $11 \mathrm{~A}$ & 0.0 & 0.8 & 0.5 & 15 & 1 & & 0.0 & & & & 0.0 & & & 0.0 & & & \\
\hline 10 & 12 & 0.0 & 87.1 & 67.3 & 13 & 1 & & 0.0 & & & & 0.0 & & & 0.0 & 1157 & & \\
\hline 10 & $12 A$ & 81.0 & 57.4 & 8.2 & 1 & 1 & 3 & 1.0 & 1 & 2 & 3 & 1.0 & 5 & 1975 & 1.1 & 520 & & \\
\hline 10 & 13 & 119.9 & 53.5 & 5.6 & 1 & 1 & 4 & 1.0 & 1 & 2 & 3 & 2.0 & 7 & 1986 & 1.3 & 300 & 1 & \\
\hline 10 & $13 \mathrm{~A}$ & 91.8 & 51.3 & 5.5 & 1 & 1 & 4 & 1.0 & 1 & 2 & 3 & 2.0 & 6 & 1988 & 1.0 & 300 & & \\
\hline 10 & 14 & 61.6 & 44.4 & 2.9 & 1 & 1 & 3 & 1.0 & 1 & 2 & 3 & 1.0 & 4 & 1976 & 1.0 & 172 & 1 & \\
\hline 10 & 15 & 0.0 & 0.0 & 0.0 & 1 & 1 & 3 & 1.0 & 0 & 2 & 2 & 0.0 & 4 & 1940 & 1.1 & & & \\
\hline 10 & 15 & 130.1 & 53.8 & 5.8 & 1 & 1 & 3 & 1.0 & 1 & 2 & 3 & 1.5 & 9 & 1972 & 2.1 & 340 & 1 & \\
\hline 10 & 16 & 42.2 & 58.1 & 8.7 & 1 & 1 & 2 & 1.0 & 1 & 2 & 2 & 1.0 & 4 & 1955 & 1.1 & 510 & 1 & \\
\hline 10 & 17 & 26.4 & 43.9 & 2.9 & 1 & 1 & 2 & 1.0 & 1 & 2 & 1 & 1.0 & 2 & 1940 & 0.6 & 170 & 1 & \\
\hline 10 & 18 & 48.6 & 53.4 & 5.5 & 1 & 1 & 3 & 1.0 & 1 & 2 & 2 & 1.0 & 3 & 1974 & 0.7 & 300 & 1 & \\
\hline 10 & 19 & 0.0 & 49.1 & 8.0 & 13 & 1 & & 0.0 & & & & 0.0 & & & 0.0 & 750 & & \\
\hline 10 & 20 & 73.4 & 66.7 & 12.0 & 6 & 4 & 3 & 1.0 & 1 & 4 & 0 & 0.0 & & 1989 & 1.5 & 1425 & & \\
\hline 10 & 21 & 53.8 & 0.1 & 0.0 & 1 & 4 & 3 & 1.0 & 1 & 2 & 3 & 1.0 & 6 & 1965 & 1.3 & & & \\
\hline 10 & 21 & 59.2 & 67.5 & 5.6 & 6 & 4 & 3 & 0.0 & & 2 & & 0.0 & & 1940 & 2.2 & 301 & & \\
\hline 10 & $22 \mathrm{~A}$ & 67.5 & 44.6 & 5.0 & 1 & 1 & 3 & 2.0 & 1 & 2 & 3 & 1.0 & 6 & 1930 & 0.8 & & & \\
\hline 10 & 23 & 77.3 & 37.9 & 1.5 & 1 & 4 & 3 & 1.0 & 1 & 2 & 1 & 1.0 & 5 & 1950 & 1.2 & 0 & & \\
\hline 10 & 24 & 26.6 & 10.3 & 0.2 & 1 & 4 & 2 & 1.0 & 1 & 2 & 2 & 1.0 & 4 & 1875 & 0.6 & & & \\
\hline 10 & 24 & 9.5 & 10.3 & 0.3 & 5 & 4 & 1 & 0.0 & & 2 & & 0.0 & & 1900 & 0.8 & 157 & & \\
\hline 10 & 25 & 0.0 & 61.7 & 23.2 & 14 & 4 & & 0.0 & & & & 0.0 & & & 0.0 & 1250 & 1 & \\
\hline 10 & $25 A$ & 56.2 & 54.9 & 0.8 & 6 & 4 & 2 & 0.0 & & 2 & & 0.0 & & 1945 & 1.4 & & & \\
\hline 10 & 25B & 137.3 & 74.3 & 10.1 & 6 & 4 & 2 & 0.0 & & 2 & & 0.0 & & 1935 & 4.2 & & & \\
\hline 10 & 26 & 78.5 & 45.2 & 5.4 & 1 & 4 & 3 & 1.0 & 1 & 2 & 3 & 1.5 & 5 & 1966 & 1.2 & 469 & & \\
\hline 10 & $26 A$ & 180.3 & 60.8 & 1.5 & 6 & 4 & 2 & 0.0 & & 2 & & 0.0 & & 1974 & 5.1 & 200 & & \\
\hline 10 & 27 & 0.0 & 23.9 & 41.0 & 15 & 1 & & 0.0 & & & & 0.0 & & & 0.0 & 0 & 1 & \\
\hline 10 & $27 \mathrm{~A}$ & 75.3 & 54.6 & 16.0 & 1 & 4 & 3 & 1.0 & 1 & 2 & 3 & 1.0 & 6 & 1956 & 1.3 & 22 & 1 & \\
\hline 10 & 28 & 0.0 & 53.1 & 20.0 & 13 & 4 & & 0.0 & & & & 0.0 & & & 0.0 & 1229 & & \\
\hline 10 & $28 \mathrm{~A}$ & 0.0 & 52.9 & 20.2 & 13 & 4 & & 0.0 & & & & 0.0 & & & 0.0 & 300 & & \\
\hline 10 & 29 & 40.2 & 83.6 & 115.0 & 12 & 1 & 2 & 1.0 & 1 & 1 & & 1.0 & 3 & 1960 & 1.3 & 1000 & & \\
\hline
\end{tabular}




\begin{tabular}{|c|c|c|c|c|c|c|c|c|c|c|c|c|c|c|c|c|c|c|}
\hline Map & Lot & $\begin{array}{l}\text { Bldg. } \\
\text { Value }\end{array}$ & $\begin{array}{l}\text { Land } \\
\text { Value }\end{array}$ & Acres & $\begin{array}{l}\text { Land } \\
\text { Use }\end{array}$ & Zoning & $\begin{array}{l}\text { Bldg. } \\
\text { Grade }\end{array}$ & $\begin{array}{l}\text { \# of } \\
\text { Stories }\end{array}$ & $\begin{array}{l}\text { Occu- } \\
\text { pancy }\end{array}$ & $\begin{array}{l}\text { Heat } \\
\text { Type }\end{array}$ & $\begin{array}{l}\text { \# of } \\
\text { Beds }\end{array}$ & $\begin{array}{l}\text { \# of } \\
\text { Baths }\end{array}$ & $\begin{array}{l}\text { Total } \\
\text { Rooms }\end{array}$ & $\begin{array}{l}\text { Year } \\
\text { Built }\end{array}$ & $\begin{array}{l}\text { lat } \\
\text { Floor }\end{array}$ & Frontage & $\begin{array}{l}\text { Wet- } \\
\text { lands }\end{array}$ & $\begin{array}{l}\text { Water- } \\
\text { shed }\end{array}$ \\
\hline 10 & 30 & 94.8 & 44.8 & 6.5 & 1 & 1 & 4 & 2.0 & 1 & 2 & 3 & 1.5 & 6 & 1988 & 0.7 & 0 & & \\
\hline 10 & 31 & 99.9 & 44.3 & 4.4 & 1 & 4 & 3 & 1.0 & 1 & 3 & 2 & 1.0 & 5 & 1936 & 0.9 & 17 & 1 & \\
\hline 10 & 31 & 0.0 & 0.0 & 0.0 & 1 & 4 & 3 & 1.0 & 1 & 3 & 2 & 1.0 & 3 & 1947 & 0.5 & & & \\
\hline 10 & 31 & 0.0 & 0.0 & 0.0 & 1 & 4 & 3 & 1.0 & 1 & 2 & 2 & 1.0 & 3 & 1947 & 0.6 & & & \\
\hline 10 & 32 & 50.6 & 52.9 & 0.6 & 6 & 4 & 3 & 0.0 & 0 & & & 0.0 & & 1950 & 0.8 & 303 & & \\
\hline 10 & 33 & 93.9 & 66.1 & 4.6 & 6 & 4 & 3 & 0.0 & & & & 0.0 & & 1982 & 1.4 & 300 & 1 & \\
\hline 10 & 34 & 20.9 & 45.2 & 5.4 & 1 & 4 & 3 & 1.0 & 1 & 1 & 2 & 1.0 & 4 & 1822 & 1.1 & 630 & 1 & 1 \\
\hline 10 & 35 & 0.0 & 49.3 & 14.0 & 13 & 4 & & 0.0 & & & & 0.0 & & & 0.0 & 700 & & 1 \\
\hline 10 & $35 \mathrm{~A}$ & 0.0 & 76.8 & 105.0 & 13 & 1 & & 0.0 & & & & 0.0 & & & 0.0 & 1500 & & 1 \\
\hline 10 & 36 & 147.7 & 68.6 & 11.0 & 6 & 4 & 3 & 0.0 & & & & 0.0 & & 1965 & 3.0 & 3547 & & 1 \\
\hline 10 & 37 & 180.7 & 68.5 & 6.1 & 6 & 4 & 5 & 1.0 & 1 & 2 & 3 & 1.0 & 5 & 1806 & 0.9 & 500 & & 1 \\
\hline 10 & 37 & 0.0 & 0.0 & 0.0 & 6 & 4 & 3 & 0.0 & & 2 & & 0.0 & & 1950 & 1.6 & & & 1 \\
\hline 10 & 37 & 0.0 & 0.0 & 0.0 & 6 & 4 & 3 & 0.0 & & 2 & & 0.0 & & 1950 & 1.0 & & & 1 \\
\hline 10 & $37 \mathrm{~A}$ & 39.2 & 60.4 & 1.9 & 5 & 4 & 3 & 0.0 & & 2 & & 0.0 & & 1960 & 1.1 & & & 1 \\
\hline 10 & 38 & 0.0 & 0.0 & 0.0 & 1 & 4 & 1 & 1.0 & 1 & 3 & 1 & 1.0 & 5 & 1959 & 0.6 & & & 1 \\
\hline 10 & 38 & 57.7 & 72.2 & 49.0 & 1 & 4 & 2 & 1.0 & 1 & 3 & 3 & 1.0 & 3 & 1945 & 0.9 & 1275 & & 1 \\
\hline 10 & 40 & 0.0 & 79.4 & 54.0 & 13 & 1 & & 0.0 & & & & 0.0 & & & 0.0 & 575 & & 1 \\
\hline 10 & 41 & 52.8 & 58.2 & 8.7 & 1 & 1 & 3 & 1.0 & 1 & 1 & 2 & 1.0 & 5 & 1900 & 1.1 & 1250 & & 1 \\
\hline 10 & 41 & 28.5 & 0.0 & 0.0 & 5 & 1 & 2 & 1.0 & 1 & 1 & 1 & 1.0 & 4 & 1900 & 0.4 & & & 1 \\
\hline 10 & 42 & 0.0 & 2.4 & 0.3 & 13 & 1 & & 0.0 & & & & 0.0 & & & 0.0 & 50 & & 1 \\
\hline 10 & 43 & 0.0 & 48.5 & 7.6 & 13 & 1 & & 0.0 & & & & 0.0 & & & 0.0 & 494 & & 1 \\
\hline 10 & $43 \mathrm{~A}$ & 0.0 & 51.2 & 2.1 & 14 & 4 & & 0.0 & & & & 0.0 & & & 0.0 & 226 & & 1 \\
\hline 10 & 43B & 0.0 & 50.5 & 2.0 & 14 & 4 & & 0.0 & & & & 0.0 & & & 0.0 & 226 & & 1 \\
\hline 10 & $43 \mathrm{C}$ & 0.0 & 50.5 & 2.0 & 14 & 4 & & 0.0 & & & & 0.0 & & & 0.0 & 225 & & 1 \\
\hline 10 & 43D & 0.0 & 50.5 & 2.0 & 14 & 4 & & 0.0 & & & & 0.0 & & & 0.0 & 225 & & 1 \\
\hline 10 & $43 E$ & 0.0 & 50.5 & 2.0 & 14 & 4 & & 0.0 & & & & 0.0 & & & 0.0 & 225 & & 1 \\
\hline 10 & $43 F$ & 0.0 & 50.5 & 2.0 & 14 & 4 & & 0.0 & & & & 0.0 & & & 0.0 & 225 & 1 & 1 \\
\hline 10 & $43 G$ & 0.0 & 50.5 & 2.0 & 14 & 4 & & 0.0 & & & & 0.0 & & & 0.0 & 225 & & 1 \\
\hline 10 & $43 \mathrm{H}$ & 0.0 & 50.2 & 1.8 & 14 & 4 & & 0.0 & & & & 0.0 & & & 0.0 & 212 & & 1 \\
\hline 10 & 44 & 99.1 & 34.0 & 2.0 & 1 & 4 & 4 & 1.5 & 1 & 2 & 4 & 1.5 & 6 & 1948 & 1.7 & 228 & & 1 \\
\hline 10 & 45 & 90.8 & 78.7 & 56.5 & 2 & 4 & 3 & 1.0 & 1 & 2 & 3 & 2.0 & 7 & 1944 & 1.8 & 1300 & & 1 \\
\hline 10 & $45 A$ & 0.0 & 23.0 & 29.5 & 13 & 1 & & 0.0 & & & & 0.0 & & & 0.0 & 0 & 1 & 1 \\
\hline 10 & 46 & 89.4 & 50.5 & 13.0 & 1 & 4 & 3 & 1.0 & 1 & 2 & 4 & 1.5 & 6 & 1948 & 1.2 & 1200 & & 1 \\
\hline 10 & 47 & 27.7 & 33.2 & 1.7 & 1 & 4 & 2 & 1.0 & 1 & 3 & 2 & 1.0 & 4 & 1900 & 0.7 & 560 & & \\
\hline 10 & 48 & 89.0 & 44.2 & 2.9 & 1 & 1 & 3 & 2.0 & 1 & 2 & 4 & 2.0 & 8 & 1940 & 1.0 & 442 & 1 & \\
\hline 10 & 49 & 65.9 & 81.0 & 40.0 & 1 & 1 & 3 & 1.0 & 1 & 2 & 2 & 1.0 & 5 & 1925 & 0.9 & 274 & 1 & 1 \\
\hline 10 & 50 & 72.6 & 53.8 & 9.0 & 1 & 1 & 3 & 1.5 & 1 & 2 & 2 & 1.0 & 5 & 1910 & 1.6 & 361 & 1 & 1 \\
\hline 10 & 51 & 34.4 & 38.6 & 1.6 & 2 & 1 & 2 & 1.0 & 1 & 2 & 2 & 1.0 & 4 & 1900 & 0.8 & 244 & & \\
\hline 10 & 52 & 46.0 & 61.2 & 10.9 & 1 & 1 & 3 & 1.0 & 1 & 2 & 1 & 1.0 & 4 & 1900 & 0.8 & 650 & 1 & 1 \\
\hline 10 & 53 & 108.5 & 80.9 & 41.0 & 6 & 1 & 3 & 0.0 & & 2 & & 0.0 & & 1925 & 3.9 & 2391 & 1 & 1 \\
\hline
\end{tabular}




\begin{tabular}{|c|c|c|c|c|c|c|c|c|c|c|c|c|c|c|c|c|c|c|}
\hline Map & Lot & $\begin{array}{l}\text { Bldg. } \\
\text { Value }\end{array}$ & $\begin{array}{l}\text { Land } \\
\text { Value }\end{array}$ & Acres & $\begin{array}{l}\text { Land } \\
\text { Use }\end{array}$ & Zoning & $\begin{array}{l}\text { Bldg. } \\
\text { Grade }\end{array}$ & $\begin{array}{l}\text { of } \\
\text { Stories }\end{array}$ & $\begin{array}{l}\text { Occu- } \\
\text { pancy }\end{array}$ & $\begin{array}{l}\text { Heat } \\
\text { Type }\end{array}$ & $\begin{array}{l}\text { \# of } \\
\text { Beds }\end{array}$ & $\begin{array}{l}\text { of } \\
\text { Baths }\end{array}$ & $\begin{array}{l}\text { Total } \\
\text { Rooms }\end{array}$ & $\begin{array}{l}\text { Year } \\
\text { Built }\end{array}$ & $\begin{array}{l}\text { 1st } \\
\text { Floor }\end{array}$ & Frontage & $\begin{array}{l}\text { Wet- } \\
\text { lands }\end{array}$ & $\begin{array}{l}\text { Water- } \\
\text { ahed }\end{array}$ \\
\hline 10 & 54 & 0.0 & 76.7 & 47.0 & 13 & 1 & & 0.0 & & & & 0.0 & & & 0.0 & 442 & 1 & 1 \\
\hline 10 & 55 & 59.7 & 48.0 & 3.8 & 1 & 1 & 3 & 1.0 & 1 & 2 & 2 & 1.0 & 4 & 1966 & 1.0 & 330 & & 1 \\
\hline 10 & 56 & 60.0 & 77.6 & 39.0 & 1 & 1 & 3 & 1.5 & $i$ & 2 & 4 & 1.0 & 7 & 1900 & 1.1 & 1700 & 1 & 1 \\
\hline 10 & 57 & 0.0 & 2.6 & 1.8 & 15 & 1 & & 0.0 & & & & 0.0 & & & 0.0 & 0 & & 1 \\
\hline 10 & 58 & 0.0 & 47.5 & 14.0 & 13 & $i$ & & 0.0 & & & & 0.0 & & & 0.0 & 640 & 1 & 1 \\
\hline 10 & 59 & 116.1 & 73.8 & 27.0 & 1 & 1 & 3 & 1.5 & 1 & 2 & 3 & 1.0 & 7 & 1930 & 0.9 & 2632 & & 1 \\
\hline 10 & 59 & 0.0 & 0.0 & 0.0 & $i$ & $i$ & 2 & 1.5 & 1 & 1 & 2 & 1.0 & 5 & 1930 & 0.8 & & & 1 \\
\hline 10 & 60 & 21.8 & 0.0 & 0.0 & 15 & 1 & 1 & 1.0 & 1 & 2 & 1 & 1.0 & 3 & 1935 & 0.7 & & & $i$ \\
\hline 10 & 60 & 60.2 & 69.5 & 20.2 & 1 & 1 & 3 & 1.0 & 1 & 2 & 4 & 1.0 & 6 & 1942 & 0.8 & 449 & & 1 \\
\hline 10 & $60 \mathrm{~A}$ & 102.5 & 52.1 & 4.7 & $i$ & 1 & 4 & 2.0 & 1 & 2 & 4 & 2.0 & 6 & 1975 & 1.1 & 300 & & 1 \\
\hline 10 & 61 & 117.0 & 69.6 & 20.3 & 1 & 1 & 4 & 2.0 & 1 & 4 & 3 & 2.5 & 2 & 1988 & 1.2 & 760 & & 1 \\
\hline 10 & $61 \mathrm{~A}$ & 106.4 & 53.2 & 5.4 & 1 & 1 & 4 & 2.0 & 1 & 2 & 3 & 2.5 & 5 & 1988 & 1.2 & & & \\
\hline 10 & 62 & 138.9 & 56.4 & 7.5 & $i$ & $i$ & 4 & 1.0 & $i$ & 2 & 1 & 2.5 & 6 & 1987 & 1.3 & 958 & & \\
\hline 10 & 63 & 0.0 & 44.1 & 4.6 & 13 & 1 & & 0.0 & & & & 0.0 & & & 0.0 & 231 & & \\
\hline 10 & 64 & 0.0 & 58.6 & 15.5 & 13 & 1 & & 0.0 & & & & 0.0 & & & 0.0 & 2025 & & 1 \\
\hline 10 & $64 \mathrm{~A}$ & 42.9 & 54.9 & 6.5 & 1 & 1 & 4 & 2.0 & 1 & 2 & 3 & 2.0 & 6 & 1989 & 1.0 & & & \\
\hline 10 & $64 \mathrm{~B}$ & 0.0 & 46.2 & 6.0 & 13 & 1 & & 0.0 & & & & 0.0 & & & 0.0 & & & \\
\hline 10 & $64 C$ & 0.0 & 45.8 & 5.8 & 13 & 1 & & 0.0 & & & & 0.0 & & & 0.0 & & & \\
\hline 10 & 64D & 0.0 & 44.4 & 4.9 & 13 & 1 & & 0.0 & & & & 0.0 & & & 0.0 & & & \\
\hline 10 & 65 & 0.0 & 0.4 & 0.3 & 15 & 1 & & 0.0 & & & & 0.0 & & & 0.0 & 0 & & 1 \\
\hline 10 & 66 & 0.0 & 7.8 & 5.2 & 15 & 1 & & 0.0 & & & & 0.0 & & & 0.0 & 0 & & 1 \\
\hline 10 & 67 & 0.0 & 92.8 & 80.2 & 13 & 1 & & 0.0 & & & & 0.0 & & & 0.0 & 0 & & 1 \\
\hline 10 & 68 & 0.0 & 25.0 & 0.5 & 15 & 1 & & 0.0 & & & & 0.0 & & & 0.0 & 0 & & 1 \\
\hline 10 & 69 & 74.9 & 37.9 & 1.5 & 1 & 1 & 3 & 1.0 & 1 & 2 & 3 & 1.0 & 6 & 1979 & 0.9 & 324 & & \\
\hline 10 & 70 & 80.5 & 48.8 & 4.0 & $i$ & 1 & 3 & 1.0 & 1 & 2 & 3 & 1.0 & 5 & 1950 & 1.6 & 208 & & \\
\hline 10 & 71 & 0.0 & 59.4 & 18.3 & 13 & 1 & & 0.0 & & & & 0.0 & & & 0.0 & 392 & & \\
\hline 10 & $71 \mathrm{~A}$ & 61.6 & 52.1 & 4.7 & 1 & 1 & 3 & 1.5 & 1 & 2 & 2 & 1.0 & 6 & 1920 & 0.9 & 392 & & \\
\hline 10 & 72 & 0.0 & 65.0 & 26.0 & 13 & 1 & & 0.0 & & & & 0.0 & & & 0.0 & 2128 & 1 & \\
\hline 10 & 73 & 0.0 & 54.6 & 12.0 & 13 & 1 & & 0.0 & & & & 0.0 & & & 0.0 & 300 & & \\
\hline 10 & $73 \mathrm{~A}$ & 0.0 & 58.7 & 22.7 & 13 & 1 & & 0.0 & & & & 0.0 & & & 0.0 & 483 & & \\
\hline 10 & $73 B$ & 62.6 & 63.0 & 12.3 & 1 & 1 & 3 & 1.0 & 1 & 2 & 2 & 1.0 & 4 & 1988 & 1.1 & 303 & & \\
\hline 10 & $73 C$ & 0.0 & 54.7 & 12.1 & 13 & 1 & & 0.0 & & & & 0.0 & & & 0.0 & 304 & & \\
\hline 10 & 74 & 139.0 & 80.6 & 39.4 & 1 & 1 & 4 & 1.0 & 1 & 2 & 3 & 2.0 & 8 & 1988 & 1.3 & 2950 & 1 & \\
\hline 10 & $74 \mathrm{~A}$ & 74.7 & 53.8 & 5.8 & 1 & 1 & 3 & 1.0 & $i$ & 2 & 3 & 1.5 & 5 & 1962 & 1.6 & & & \\
\hline 10 & 75 & 92.8 & 66.0 & 18.4 & 1 & $i$ & 5 & 1.5 & 1 & 3 & 2 & 1.5 & 4 & 1984 & 1.0 & 818 & 1 & \\
\hline 10 & 76 & 72.9 & 35.3 & 0.9 & 1 & $i$ & 3 & 1.0 & $i$ & 2 & 2 & 1.0 & 3 & 1988 & 0.9 & & & \\
\hline 10 & 78 & 0.0 & 0.0 & 0.0 & 6 & 1 & 3 & 0.0 & 1 & 2 & & 0.0 & & 1988 & 3.5 & 880 & 1 & \\
\hline 10 & 78 & 161.3 & 64.2 & 4.3 & 6 & 4 & 3 & 1.0 & 1 & 2 & 2 & 1.0 & 4 & 1969 & 0.9 & 100 & & \\
\hline 10 & 79 & 5.2 & 37.8 & 3.1 & 1 & 4 & 1 & 1.0 & 1 & 2 & 2 & 1.0 & 4 & 1970 & 0.8 & 284 & 1 & \\
\hline 10 & 81 & 21.3 & 59.7 & 3.7 & 6 & 4 & 3 & 0.0 & $i$ & 2 & & 0.0 & & 1945 & 4.0 & 400 & 1 & \\
\hline
\end{tabular}




\begin{tabular}{|c|c|c|c|c|c|c|c|c|c|c|c|c|c|c|c|c|c|c|}
\hline Map & Lot & $\begin{array}{l}\text { Bldg. } \\
\text { Value }\end{array}$ & $\begin{array}{l}\text { Land } \\
\text { Value }\end{array}$ & Acres & $\begin{array}{l}\text { Land } \\
\text { Use }\end{array}$ & Zoning & $\begin{array}{l}\text { Bldg. } \\
\text { Grade }\end{array}$ & $\begin{array}{l}\text { \# of } \\
\text { Stories }\end{array}$ & $\begin{array}{l}\text { Occu- } \\
\text { pancy }\end{array}$ & $\begin{array}{l}\text { Heat } \\
\text { Type }\end{array}$ & $\begin{array}{l}\text { \# of } \\
\text { Beds }\end{array}$ & $\begin{array}{l}\text { \# of } \\
\text { Baths }\end{array}$ & $\begin{array}{l}\text { Total } \\
\text { Rooms }\end{array}$ & $\begin{array}{l}\text { Year } \\
\text { Built }\end{array}$ & $\begin{array}{l}\text { 1st } \\
\text { Floor }\end{array}$ & Frontage & $\begin{array}{l}\text { Wet- } \\
\text { lands }\end{array}$ & $\begin{array}{l}\text { Water- } \\
\text { shed }\end{array}$ \\
\hline 10 & 81 & 23.1 & 0.0 & 0.0 & 5 & 4 & 1 & 0.0 & & 2 & & 0.0 & & 1955 & 0.8 & & & \\
\hline 10 & 82 & 0.0 & 60.2 & 27.5 & 13 & 4 & & 0.0 & & & & 0.0 & & & 0.0 & 800 & 1 & \\
\hline 10 & $82 \mathrm{~A}$ & 36.7 & 53.5 & 5.6 & 1 & 1 & 3 & 1.0 & 1 & 2 & 3 & 2.0 & 7 & 1989 & 1.1 & & & \\
\hline 10 & $82 B$ & 0.0 & 44.1 & 4.6 & 13 & 1 & & 0.0 & & & & 0.0 & & & 0.0 & & & \\
\hline 10 & 83 & 0.0 & 58.2 & 24.5 & 13 & 4 & & 0.0 & & & & 0.0 & & & 0.0 & 653 & 1 & \\
\hline 10 & 84 & 0.0 & 54.3 & 24.8 & 13 & 4 & & 0.0 & & & & 0.0 & & & 0.0 & 312 & 1 & \\
\hline 10 & 85 & 59.3 & 62.0 & 1.1 & 6 & 4 & 3 & 0.0 & 1 & 3 & & 0.0 & & 1945 & 1.3 & 210 & & \\
\hline 10 & 86 & 112.2 & 62.3 & 1.0 & 6 & 4 & 3 & 0.0 & & 2 & & 0.0 & & 1960 & 2.0 & 210 & & \\
\hline 10 & 87 & 0.0 & 79.5 & 31.0 & 14 & 4 & & 0.0 & & & & 0.0 & & & 0.0 & 1200 & 1 & \\
\hline 10 & 88 & 54.1 & 45.1 & 8.2 & 2 & 4 & 3 & 2.0 & 2 & 2 & 3 & 2.0 & 6 & 1930 & 1.0 & 1070 & & \\
\hline 10 & 88 & 203.5 & 61.0 & 4.8 & 6 & 1 & 2 & 0.0 & & 2 & & 0.0 & & 1950 & 2.3 & & & \\
\hline 10 & 88 & 0.0 & 0.0 & 0.0 & 6 & 1 & 3 & 0.0 & & 3 & & 0.0 & & 1950 & 3.9 & & & \\
\hline 10 & $88 B$ & 0.0 & 59.5 & 18.0 & 13 & 1 & & 0.0 & & & & 0.0 & & & 0.0 & & & \\
\hline 10 & $88 \mathrm{C}$ & 0.0 & 91.6 & 76.9 & 13 & 1 & & 0.0 & & & & 0.0 & & & 0.0 & & & \\
\hline 10 & 89 & 88.9 & 53.4 & 5.5 & 1 & 1 & 3 & 1.0 & 1 & 4 & 3 & 1.5 & 5 & 1980 & 1.1 & 500 & & \\
\hline 10 & 90 & 73.0 & 57.1 & 8.0 & 1 & 1 & 3 & 1.0 & 1 & 2 & 2 & 1.0 & 6 & 1925 & 0.9 & 484 & & \\
\hline 10 & 91 & 0.0 & 41.8 & 4.0 & 13 & 1 & & 0.0 & & & & 0.0 & & & 0.0 & 80 & & \\
\hline 10 & 93 & 0.0 & 16.1 & 14.8 & 15 & $i$ & & 0.0 & & & & 0.0 & & & 0.0 & 0 & 1 & \\
\hline 10 & 94 & 0.0 & 8.3 & 5.5 & 15 & 1 & & 0.0 & & & & 0.0 & & & 0.0 & 0 & & 1 \\
\hline 10 & 95 & 0.0 & 59.2 & 18.4 & 13 & 1 & & 0.0 & & & & 0.0 & & & 0.0 & 20 & 1 & \\
\hline 11 & 1 & 18.7 & 68.2 & 18.0 & 1 & 1 & 6 & 1.5 & 1 & 2 & 2 & 2.0 & 5 & 1800 & 1.6 & 1150 & 1 & 1 \\
\hline 11 & 2 & 163.7 & 68.8 & 19.0 & 2 & 1 & 6 & 1.5 & 1 & 2 & 3 & 2.0 & 6 & 1850 & 1.3 & 1043 & 1 & 1 \\
\hline 11 & 3 & 0.0 & 7.5 & 5.0 & 13 & $i$ & & 0.0 & & & & 0.0 & & & 0.0 & 246 & i & 1 \\
\hline 11 & 4 & 91.4 & 73.2 & 26.0 & 1 & 1 & 3 & 1.0 & 1 & 2 & 3 & 2.0 & 6 & 1987 & 1.4 & 1400 & 1 & 1 \\
\hline 11 & $4 A$ & 93.7 & 52.6 & 5.0 & 1 & i & 3 & 1.0 & 1 & 2 & 3 & 1.0 & 8 & 1965 & 1.5 & 300 & & 1 \\
\hline 11 & 5 & 75.2 & 64.6 & 13.0 & 1 & 1 & 3 & 1.5 & 1 & 4 & 3 & 2.0 & 4 & 1987 & 1.1 & 475 & 1 & 1 \\
\hline 11 & $5 A$ & 54.9 & 64.0 & 13.0 & 1 & 1 & 3 & 1.0 & $i$ & 2 & 1 & 1.0 & 3 & 1880 & 0.9 & 696 & 1 & 1 \\
\hline 11 & 6 & 0.0 & 72.0 & 40.8 & 13 & 1 & & 0.0 & & & & 0.0 & & & 0.0 & 1000 & 1 & 1 \\
\hline 11 & $6 A$ & 80.7 & 60.1 & 10.0 & 1 & $i$ & 2 & 1.0 & 1 & 1 & 3 & 2.0 & 6 & 1980 & 1.5 & 1328 & & 1 \\
\hline 11 & 7 & 226.8 & 86.5 & 50.0 & 1 & 1 & 7 & 2.0 & 1 & 2 & 4 & 3.5 & 10 & 1980 & 2.0 & 3667 & 1 & i \\
\hline 11 & 9 & 58.0 & 53.9 & 8.3 & 1 & 1 & 2 & 1.0 & 1 & 4 & 1 & 1.0 & 5 & 1972 & 1.2 & 267 & & 1 \\
\hline 11 & 10 & 0.0 & 56.4 & 13.3 & 13 & 1 & & 0.0 & & & & 0.0 & & & 0.0 & 1013 & 1 & 1 \\
\hline 11 & 11 & 10.7 & 24.5 & 17.0 & 1 & 1 & 3 & 1.0 & 1 & 2 & 3 & 1.0 & 6 & 1986 & 0.9 & 1950 & & $i$ \\
\hline 11 & 12 & 84.8 & 71.9 & 25.6 & 1 & 1 & 4 & 1.0 & $i$ & 1 & 2 & 2.0 & 5 & 1850 & 1.4 & 2198 & 1 & 1 \\
\hline 11 & 13 & 107.6 & 62.6 & 15.0 & 1 & 1 & 4 & 1.5 & 1 & 2 & 3 & 1.5 & 6 & 1967 & 1.0 & 600 & 1 & 1 \\
\hline 11 & 15 & 0.0 & 45.4 & 5.5 & 13 & $i$ & & 0.0 & & & & 0.0 & & & 0.0 & 350 & 1 & 1 \\
\hline 11 & 16 & 89.6 & 62.6 & 13.4 & 1 & 1 & 3 & 1.0 & 1 & 2 & 3 & 2.0 & 6 & 1971 & 1.4 & 520 & 1 & 1 \\
\hline 11 & 17 & 17.8 & 56.4 & 7.5 & 1 & 1 & 1 & 1.0 & 1 & 3 & 2 & 1.0 & 4 & 1930 & 0.8 & 400 & & 1 \\
\hline 11 & 18 & 53.9 & 31.6 & 0.6 & 1 & 1 & 3 & 1.0 & 1 & 2 & 1 & 1.0 & 3 & 1935 & 0.8 & 130 & & $i$ \\
\hline 11 & 19 & 72.8 & 47.5 & 6.9 & 1 & 4 & 3 & 1.0 & 1 & 2 & 2 & 1.5 & 6 & 1960 & 1.2 & 1597 & & 1 \\
\hline
\end{tabular}




\begin{tabular}{|c|c|c|c|c|c|c|c|c|c|c|c|c|c|c|c|c|c|c|}
\hline Map & Lot & $\begin{array}{l}\text { Bldg. } \\
\text { Value }\end{array}$ & $\begin{array}{l}\text { Land } \\
\text { Value }\end{array}$ & Acres & $\begin{array}{l}\text { Land } \\
\text { Use }\end{array}$ & Zoning & $\begin{array}{l}\text { Bldg. } \\
\text { Grade }\end{array}$ & $\begin{array}{l}\text { \# of } \\
\text { Stories }\end{array}$ & $\begin{array}{l}\text { Occu- } \\
\text { pancy }\end{array}$ & $\begin{array}{l}\text { Heat } \\
\text { Type }\end{array}$ & $\begin{array}{l}\text { \# of } \\
\text { Beds }\end{array}$ & $\begin{array}{l}\text { \# of } \\
\text { Baths }\end{array}$ & $\begin{array}{l}\text { Total } \\
\text { Rooms }\end{array}$ & $\begin{array}{l}\text { Year } \\
\text { Built }\end{array}$ & $\begin{array}{l}\text { 1st } \\
\text { Floor }\end{array}$ & Frontage & $\begin{array}{l}\text { Wet- } \\
\text { lands }\end{array}$ & $\begin{array}{l}\text { Waler- } \\
\text { shed }\end{array}$ \\
\hline 11 & $19 A$ & 95.5 & 48.6 & 7.7 & 1 & 1 & 3 & 1.0 & 1 & 2 & 2 & 3.0 & 5 & 1976 & 1.0 & & & 1 \\
\hline 11 & 19B & 0.0 & 0.0 & 0.0 & 6 & 1 & 3 & 0.0 & 1 & 2 & & 0.0 & & 1910 & 2.4 & & & 1 \\
\hline 11 & $19 \mathrm{~B}$ & 199.0 & 61.1 & 1.3 & 6 & 1 & 3 & 0.0 & & 2 & & 0.0 & & 1965 & 2.8 & & & 1 \\
\hline 11 & 20 & 50.7 & 76.4 & 11.5 & 6 & 4 & 3 & 0.0 & & 2 & & 0.0 & & 1920 & 1.2 & 500 & 1 & 1 \\
\hline 11 & 21 & 0.0 & 39.8 & 5.8 & 13 & 1 & & 0.0 & & & & 0.0 & & & 0.0 & 15 & & 1 \\
\hline 11 & $21 \mathrm{~A}$ & 69.4 & 25.1 & 0.5 & 1 & 4 & 3 & 1.0 & 1 & 2 & 2 & 1.0 & 4 & 1937 & 1.0 & 150 & & 1 \\
\hline 11 & $21 B$ & 44.5 & 25.0 & 0.5 & 1 & 4 & 2 & 2.0 & 1 & 2 & 3 & 1.0 & 6 & 1940 & 0.9 & 112 & & 1 \\
\hline 11 & 22 & 80.1 & 47.5 & 6.9 & 1 & 4 & 3 & 1.0 & 1 & 2 & 1 & 1.0 & 6 & 1950 & 1.4 & 550 & & 1 \\
\hline 11 & $22 \mathrm{~A}$ & 0.0 & 49.6 & 8.4 & 13 & 1 & & 0.0 & & & & 0.0 & & & 0.0 & 738 & & 1 \\
\hline 11 & $22 \mathrm{~A} 1$ & 90.6 & 53.4 & 5.5 & 1 & 4 & 3 & 1.0 & 1 & 2 & 2 & 1.0 & 4 & 1953 & 1.3 & 945 & & 1 \\
\hline 11 & 23 & 66.1 & 37.9 & 1.4 & 1 & 4 & 3 & 1.0 & 1 & 2 & 2 & 1.0 & 8 & 1925 & 1.7 & 250 & & 1 \\
\hline 11 & 24 & 79.9 & 37.1 & 1.2 & 1 & 1 & 3 & 1.0 & 1 & 2 & 5 & 1.0 & 6 & 1945 & 1.1 & 200 & & 1 \\
\hline 11 & 25 & 88.9 & 69.9 & 21.3 & 6 & 1 & 2 & 0.0 & & 3 & & 0.0 & & 1968 & 3.9 & 30 & & 1 \\
\hline 11 & 27 & 83.9 & 68.0 & 18.2 & 1 & 1 & 4 & 1.5 & 1 & 2 & 2 & 2.0 & 6 & 1800 & 1.3 & 500 & & 1 \\
\hline 11 & 27 & 0.0 & 0.0 & 0.0 & 1 & 1 & 3 & 1.0 & 1 & 2 & 2 & 1.0 & 4 & 1970 & 0.6 & & & 1 \\
\hline 11 & 28 & 106.6 & 59.1 & 9.3 & 1 & 1 & 3 & 1.0 & 1 & 2 & 3 & 2.0 & 7 & 1976 & 1.6 & 800 & & 1 \\
\hline 11 & 29 & 0.0 & 54.7 & 12.0 & 13 & 1 & & 0.0 & & & & 0.0 & & & 0.0 & 367 & & 1 \\
\hline 11 & $29 \mathrm{~A}$ & 0.0 & 54.7 & 12.0 & 13 & 1 & & 0.0 & & & & 0.0 & & & 0.0 & 367 & & 1 \\
\hline 11 & 30 & 109.8 & 59.1 & 9.3 & 1 & 1 & 5 & 1.5 & 1 & 2 & 3 & 3.0 & 7 & 1964 & 1.4 & 350 & & 1 \\
\hline 11 & 31 & 93.1 & 64.1 & 13.1 & $i$ & 1 & 3 & 1.0 & 1 & 2 & 3 & 2.0 & 5 & 1972 & 1.4 & 425 & & 1 \\
\hline 11 & 32 & 114.2 & 60.7 & 10.6 & 1 & 1 & 4 & 1.0 & 1 & 2 & 2 & 2.0 & 8 & 1976 & 1.5 & 350 & & 1 \\
\hline 11 & 33 & 83.9 & 57.9 & 10.5 & 1 & 1 & 3 & 1.0 & 1 & 2 & 3 & 1.0 & 7 & 1968 & 1.0 & 300 & & 1 \\
\hline 11 & 34 & 11.7 & 46.7 & 6.4 & 12 & 1 & & 0.0 & & & & 0.0 & & & 0.0 & 1225 & & 1 \\
\hline 11 & 35 & 71.8 & 52.6 & 5.0 & 1 & 1 & 3 & 1.0 & 1 & 2 & 3 & 1.0 & 6 & 1977 & 1.1 & 300 & 1 & 1 \\
\hline 11 & $35 A$ & 105.9 & 62.6 & 12.0 & 1 & 1 & 4 & 1.5 & 1 & 2 & 3 & 2.0 & 7 & 1975 & 1.1 & 545 & 1 & 1 \\
\hline 11 & 36 & 83.4 & 78.4 & 35.0 & i & 1 & & 0.0 & & & & 0.0 & & & 0.0 & 3100 & 1 & 1 \\
\hline 11 & 37 & 107.8 & 70.8 & 22.1 & 9 & 1 & 4 & 1.5 & 1 & 2 & 1 & 2.0 & 3 & 1986 & 0.8 & 60 & & 1 \\
\hline 11 & $37 \mathrm{~B}$ & 118.0 & 66.5 & 15.0 & 1 & 1 & 3 & 1.0 & 1 & 2 & 3 & 2.0 & 7 & 1975 & 2.2 & 530 & & 1 \\
\hline 11 & 38 & 69.3 & 53.1 & 5.3 & 1 & 1 & 3 & 1.5 & 1 & 4 & 2 & 2.0 & 5 & 1974 & 0.9 & 300 & & 1 \\
\hline 11 & 39 & 73.1 & 52.3 & 4.8 & 1 & 1 & 3 & 1.0 & 1 & 2 & 3 & 1.0 & 6 & 1965 & 1.1 & 600 & & $i$ \\
\hline 11 & 40 & 69.8 & 48.8 & 4.0 & 1 & 1 & 3 & 1.0 & $i$ & 2 & 3 & 1.0 & 6 & 1972 & 1.2 & 340 & & 1 \\
\hline 11 & 41 & 102.8 & 54.0 & 6.0 & 1 & 1 & 5 & 1.0 & 1 & 2 & 3 & 2.0 & 7 & 1790 & 1.3 & 550 & & 1 \\
\hline 11 & $41 \mathrm{~A}$ & 0.0 & 54.6 & 12.0 & 13 & 1 & & 0.0 & & & & 0.0 & & & 0.0 & 300 & & 1 \\
\hline 11 & $41 B$ & 102.1 & 62.6 & 12.0 & 1 & 1 & 3 & 2.0 & 1 & 4 & 3 & 2.0 & 7 & 1983 & 1.1 & 400 & & 1 \\
\hline 11 & $41 C$ & 80.2 & 59.3 & 9.5 & 1 & 1 & 3 & 1.0 & 1 & 2 & 2 & 1.5 & 6 & 1983 & 1.4 & 350 & & 1 \\
\hline 11 & 41D & 0.0 & 55.6 & 16.6 & 13 & 1 & & 0.0 & & & & 0.0 & & & 0.0 & 360 & & 1 \\
\hline 11 & $41 E$ & 95.4 & 58.2 & 8.7 & 1 & 1 & 4 & 2.0 & 1 & 2 & 3 & 2.0 & 6 & 1987 & 1.0 & 300 & & $i$ \\
\hline 11 & 42 & 0.0 & 47.9 & 7.0 & 13 & 1 & & 0.0 & & & & 0.0 & & & 0.0 & 683 & & 1 \\
\hline 11 & 42B & 5.0 & 52.1 & 4.6 & 1 & 1 & & 0.0 & & & & 0.0 & & & 0.0 & 440 & & 1 \\
\hline 11 & 43 & 96.7 & 42.5 & 2.5 & 1 & 1 & 4 & 2.0 & 1 & 2 & 3 & 2.0 & 5 & 1976 & 0.8 & 390 & & 1 \\
\hline
\end{tabular}




\begin{tabular}{|c|c|c|c|c|c|c|c|c|c|c|c|c|c|c|c|c|c|c|}
\hline Map & Lot & $\begin{array}{l}\text { Bldg. } \\
\text { Value }\end{array}$ & $\begin{array}{l}\text { Land } \\
\text { Value }\end{array}$ & Acres & $\begin{array}{l}\text { Land } \\
\text { Use }\end{array}$ & Zoning & $\begin{array}{l}\text { Bldg. } \\
\text { Grade }\end{array}$ & $\begin{array}{l}\text { \# of } \\
\text { Stories }\end{array}$ & $\begin{array}{l}\text { Occu- } \\
\text { pancy }\end{array}$ & $\begin{array}{l}\text { Heat } \\
\text { Type }\end{array}$ & $\begin{array}{l}\text { \# of } \\
\text { Beds }\end{array}$ & $\begin{array}{l}\text { \# of } \\
\text { Baths }\end{array}$ & $\begin{array}{l}\text { Total } \\
\text { Rooms }\end{array}$ & $\begin{array}{l}\text { Year } \\
\text { Built }\end{array}$ & $\begin{array}{l}\text { 1st } \\
\text { Floor }\end{array}$ & Frontage & $\begin{array}{l}\text { Wet- } \\
\text { lands }\end{array}$ & $\begin{array}{l}\text { Water- } \\
\text { shed }\end{array}$ \\
\hline 11 & 44 & 57.6 & 39.2 & 1.8 & 1 & 1 & 3 & 1.0 & 1 & 2 & 2 & 1.0 & 4 & 1965 & 1.0 & 200 & & 1 \\
\hline 11 & 45 & 82.4 & 39.2 & 1.8 & 1 & 1 & 3 & 1.5 & 1 & 2 & 2 & 1.5 & 4 & 1987 & 1.0 & 200 & & 1 \\
\hline 11 & 46 & 75.3 & 59.8 & 12.3 & 1 & 1 & 3 & 1.0 & 1 & 2 & 4 & 1.0 & 6 & 1967 & 1.8 & 300 & & 1 \\
\hline 11 & 47 & 62.8 & 43.1 & 2.8 & 1 & 1 & 3 & 1.5 & 1 & 2 & 5 & 2.0 & 9 & 1954 & 1.1 & 370 & & 1 \\
\hline 11 & 48 & 0.0 & 47.3 & 6.8 & 13 & 1 & & 0.0 & & & & 0.0 & & & 0.0 & 300 & & 1 \\
\hline 11 & 49 & 4.1 & 65.7 & 27.0 & 13 & 1 & & 0.0 & & & & 0.0 & & & 0.0 & 2100 & & 1 \\
\hline 11 & 50 & 0.0 & 62.8 & 22.0 & 13 & 1 & & 0.0 & & & & 0.0 & & & 0.0 & 564 & 1 & 1 \\
\hline 11 & 51 & 0.0 & 45.8 & 9.0 & 13 & 1 & & 0.0 & & & & 0.0 & & & 0.0 & 532 & 1 & 1 \\
\hline 11 & 52 & 117.7 & 59.8 & 22.0 & 1 & 1 & 5 & 1.5 & 1 & 2 & 3 & 1.5 & 6 & 1800 & 1.6 & 1450 & 1 & 1 \\
\hline 11 & $52 B$ & 0.0 & 6.4 & 0.8 & 13 & 1 & & 0.0 & & & & 0.0 & & & 0.0 & & & 1 \\
\hline 11 & 53 & 50.7 & 37.8 & 1.4 & 1 & 1 & 3 & 1.0 & 1 & 2 & 1 & 1.0 & 5 & 1943 & 0.9 & 196 & 1 & 1 \\
\hline 11 & 54 & 83.4 & 63.4 & 12.6 & 1 & 1 & 4 & 2.0 & 1 & 3 & 2 & 1.0 & 7 & 1934 & 0.8 & 425 & 1 & 1 \\
\hline 11 & 55 & 0.0 & 72.0 & 39.0 & 13 & 1 & & 0.0 & & & & 0.0 & & & 0.0 & 300 & 1 & 1 \\
\hline 11 & $55 \mathrm{~A}$ & 53.7 & 52.7 & 6.1 & 1 & 1 & 3 & 1.0 & 1 & 2 & 2 & 1.0 & 4 & 1949 & 1.0 & 300 & 1 & 1 \\
\hline 11 & 55B & 137.4 & 52.5 & 4.9 & 1 & 1 & 4 & 1.0 & $i$ & 2 & 3 & 2.0 & 5 & 1983 & 2.4 & 300 & 1 & 1 \\
\hline 11 & 56 & 71.1 & 60.1 & 14.7 & 1 & 1 & 3 & 1.0 & 1 & 2 & 3 & 1.0 & 6 & 1986 & 1.1 & 900 & 1 & 1 \\
\hline 11 & $56 \mathrm{~B}$ & 73.0 & 52.3 & 4.8 & 1 & 1 & 3 & 1.0 & 1 & 2 & 2 & 2.0 & 6 & 1981 & 1.2 & 300 & 1 & 1 \\
\hline 11 & 57 & 0.0 & 47.6 & 7.0 & 13 & 1 & & 0.0 & & & & 0.0 & & & 0.0 & 850 & & 1 \\
\hline 11 & 58 & 8.1 & 97.4 & 53.4 & 1 & 1 & & 0.0 & & & & 0.0 & & & 0.0 & 0 & 1 & 1 \\
\hline 11 & 59 & 110.8 & 58.9 & 9.2 & 1 & 1 & 5 & 1.5 & 2 & 2 & 4 & 2.0 & 8 & 1800 & 1.5 & 494 & & 1 \\
\hline 11 & $59 \mathrm{~A}$ & 60.0 & 55.6 & 7.0 & 1 & 1 & 3 & 1.0 & 1 & 2 & 2 & 1.0 & 5 & 1988 & 0.6 & & & 1 \\
\hline 11 & 60 & 58.1 & 47.3 & 3.5 & 1 & 1 & 3 & 1.0 & 1 & 2 & 2 & 1.0 & 4 & 1940 & 0.9 & 0 & & 1 \\
\hline 11 & 61 & 42.0 & 37.9 & 1.5 & 1 & 1 & 3 & 1.0 & 1 & 2 & 1 & 1.0 & 3 & 1950 & 0.6 & 0 & & 1 \\
\hline 11 & 63 & 75.7 & 52.7 & 5.0 & 1 & 1 & 3 & 1.0 & 1 & 2 & 3 & 2.0 & 5 & 1986 & 1.2 & 400 & & 1 \\
\hline 11 & $63 \mathrm{~A}$ & 72.0 & 52.8 & 5.1 & 1 & 1 & 3 & 1.5 & 1 & 2 & 4 & 1.5 & 7 & 1985 & 0.9 & 300 & 1 & 1 \\
\hline 11 & $63 \mathrm{~B}$ & 102.8 & 52.9 & 5.1 & 1 & 1 & 4 & 1.5 & 1 & 2 & 3 & 1.5 & 7 & 1986 & 1.0 & 300 & 1 & 1 \\
\hline 11 & 64 & 81.9 & 76.8 & 37.0 & 1 & 1 & 3 & 2.0 & 1 & 2 & 4 & 1.0 & 8 & 1779 & 1.1 & 1500 & 1 & 1 \\
\hline 11 & $64 \mathrm{~A}$ & 47.5 & 36.6 & 1.0 & 1 & 1 & 2 & 1.0 & 1 & 2 & 3 & 1.0 & 6 & 1976 & 1.2 & 237 & & 1 \\
\hline 11 & 65 & 0.0 & 2.6 & 6.6 & 13 & 1 & & 0.0 & & & & 0.0 & & & 0.0 & 0 & & 1 \\
\hline 11 & $65 \mathrm{~A}$ & 0.0 & 7.5 & 5.0 & 13 & $i$ & & 0.0 & & & & 0.0 & & & 0.0 & 0 & 1 & 1 \\
\hline 11 & 67 & 94.2 & 55.5 & 8.3 & 1 & 1 & 3 & 1.0 & 1 & 2 & 3 & 1.0 & 7 & 1969 & 1.9 & 609 & 1 & 1 \\
\hline 11 & $67 \mathrm{~A}$ & 94.5 & 52.1 & 4.7 & 1 & 1 & 3 & 1.0 & 2 & 2 & 3 & 2.0 & 7 & 1982 & 1.1 & 311 & & 1 \\
\hline 11 & 68 & 67.8 & 38.9 & 1.8 & 1 & 1 & 3 & 2.0 & 1 & 2 & 3 & 1.0 & 7 & 1947 & 0.7 & 450 & & 1 \\
\hline 11 & 69 & 66.3 & 37.7 & 1.4 & 1 & 1 & 3 & 1.0 & 1 & 2 & 3 & 2.0 & 6 & 1958 & 1.2 & 300 & & 1 \\
\hline 11 & 70 & 72.7 & 37.9 & 1.5 & 1 & 1 & 3 & 1.0 & 1 & 2 & 2 & 1.0 & 4 & 1982 & 1.0 & 370 & & 1 \\
\hline 11 & 71 & 62.6 & 37.9 & 1.5 & 1 & $i$ & 3 & 1.0 & 1 & 2 & 2 & 1.0 & 5 & 1800 & 1.0 & 244 & & 1 \\
\hline 11 & 72 & 105.7 & 55.6 & 14.0 & 1 & $i$ & 3 & 2.0 & 1 & 2 & 2 & 2.0 & 5 & 1975 & 1.5 & 428 & 1 & 1 \\
\hline 11 & 73 & 22.5 & 40.1 & 2.0 & 1 & 1 & 2 & 1.0 & 1 & 2 & 1 & 1.0 & 2 & 1899 & 0.5 & 630 & 1 & 1 \\
\hline 11 & 74 & 0.0 & 44.6 & 5.0 & 13 & 1 & & 0.0 & & & & 0.0 & & & 0.0 & 763 & 1 & 1 \\
\hline 11 & $74 \mathrm{~A}$ & 100.4 & 54.4 & 6.2 & 1 & $i$ & 3 & 2.0 & 1 & 2 & 4 & 1.5 & 7 & 1988 & 0.9 & 425 & & 1 \\
\hline
\end{tabular}




\begin{tabular}{|c|c|c|c|c|c|c|c|c|c|c|c|c|c|c|c|c|c|c|}
\hline Map & Lot & $\begin{array}{l}\text { Bldg. } \\
\text { Value }\end{array}$ & $\begin{array}{l}\text { Land } \\
\text { Value }\end{array}$ & Acres & $\begin{array}{l}\text { Land } \\
\text { Use }\end{array}$ & Zoning & $\begin{array}{l}\text { Bldg. } \\
\text { Grade }\end{array}$ & $\begin{array}{l}\text { " of } \\
\text { Stories }\end{array}$ & $\begin{array}{l}\text { Occu- } \\
\text { pancy }\end{array}$ & $\begin{array}{l}\text { Heat } \\
\text { Type }\end{array}$ & $\begin{array}{l}\text { "of } \\
\text { Beds }\end{array}$ & $\begin{array}{l}\text { Wof } \\
\text { Baths }\end{array}$ & $\begin{array}{l}\text { Total } \\
\text { Rooms }\end{array}$ & $\begin{array}{l}\text { Year } \\
\text { Built. }\end{array}$ & $\begin{array}{l}\text { 1st } \\
\text { Floor }\end{array}$ & Frontage & $\begin{array}{l}\text { Wet- } \\
\text { lands }\end{array}$ & $\begin{array}{l}\text { Water- } \\
\text { shed }\end{array}$ \\
\hline 11 & 75 & 51.1 & 40.1 & 2.0 & 1 & 1 & 3 & 2.0 & 1 & 2 & 3 & 1.0 & 7 & 1800 & 0.7 & 138 & & 1 \\
\hline 11 & 77 & 0.0 & 66.9 & 32.0 & 13 & 1 & & 0.0 & & & & 0.0 & & & 0.0 & 425 & & 1 \\
\hline 11 & 78 & 84.8 & 44.4 & 3.0 & 1 & 1 & 3 & 1.0 & 1 & 2 & 4 & 2.0 & 9 & 1939 & 1.9 & 316 & & 1 \\
\hline 11 & 79 & 65.9 & 62.7 & 12.0 & 1 & 1 & 3 & 1.0 & 1 & 2 & 2 & 1.0 & 7 & 1939 & 1.3 & 294 & & 1 \\
\hline 11 & 83 & 65.7 & 36.9 & 1.1 & 1 & 1 & 3 & 1.0 & 1 & 2 & 3 & 1.0 & 5 & 1972 & 1.2 & 150 & & 1 \\
\hline 11 & 84 & 9.8 & 52.6 & 5.0 & 1 & 1 & 2 & 1.0 & 1 & 1 & 1 & 0.0 & 3 & 1941 & 0.4 & 550 & 1 & 1 \\
\hline 11 & 85 & 56.5 & 55.6 & 7.0 & 1 & 1 & 3 & 1.0 & 1 & 2 & 2 & 1.0 & 4 & 1965 & 0.9 & 1900 & & 1 \\
\hline 11 & 86 & 0.0 & 7.8 & 1.8 & 13 & 1 & & 0.0 & & & & 0.0 & & & 0.0 & 200 & 1 & 1 \\
\hline 11 & 87 & 67.1 & 67.0 & 16.0 & 1 & 1 & 3 & 2.0 & 1 & 2 & 1 & 4.0 & 4 & 1988 & 0.9 & 600 & & 1 \\
\hline 11 & 88 & 69.6 & 48.8 & 4.0 & 1 & 1 & 3 & 1.0 & 1 & 2 & 5 & 1.5 & 7 & 1945 & 1.3 & 200 & & 1 \\
\hline 11 & 89 & 0.0 & 73.0 & 50.0 & 13 & 1 & & 0.0 & & & & 0.0 & & & 0.0 & 2900 & 1 & 1 \\
\hline 11 & $89 \mathrm{~A}$ & 0.0 & 0.0 & 0.0 & 3 & 2 & 3 & 0.0 & 8 & 2 & & 0.0 & & 1982 & 6.6 & & & 1 \\
\hline 11 & $89 \mathrm{~A}$ & 986.1 & 72.2 & 26.9 & 3 & 2 & 3 & 0.0 & 8 & 3 & & 0.0 & & 1982 & 5.0 & 700 & 1 & 1 \\
\hline 11 & $89 A$ & 0.0 & 0.0 & 0.0 & 3 & 2 & 3 & 0.0 & 8 & 3 & & 0.0 & & 1982 & 5.1 & & & 1 \\
\hline 11 & $89 \mathrm{~A}$ & 0.0 & 0.0 & 0.0 & 3 & 2 & 3 & 0.0 & 6 & 3 & & 0.0 & & 1989 & 4.0 & & 1 & 1 \\
\hline 11 & $89 B$ & 149.1 & 56.6 & 8.4 & 1 & 1 & 4 & 1.0 & 1 & 2 & 4 & 2.5 & 9 & 1986 & 2.0 & 300 & 1 & 1 \\
\hline 11 & $89 \mathrm{C}$ & 92.1 & 58.6 & 9.0 & 1 & 1 & 4 & 2.0 & 1 & 2 & 3 & 1.5 & 7 & 1986 & 0.9 & 300 & & 1 \\
\hline 11 & 89D & 96.1 & 57.5 & 9.0 & 1 & 1 & 4 & 1.5 & 1 & 2 & 2 & 2.0 & 6 & 1986 & 0.9 & 300 & 1 & 1 \\
\hline 11 & $89 \mathrm{E}$ & 84.1 & 58.6 & 9.0 & 1 & 1 & 4 & 1.0 & 1 & 2 & 2 & 2.0 & 6 & 1989 & 1.1 & 300 & 1 & 1 \\
\hline 11 & 90 & 0.0 & 63.7 & 29.0 & 13 & 1 & & 0.0 & & & & 0.0 & & & 0.0 & 794 & 1 & 1 \\
\hline 11 & $90 \mathrm{~A}$ & 157.4 & 53.2 & 5.4 & 1 & 1 & 7 & 2.0 & 1 & 2 & 3 & 1.0 & 9 & 1821 & 1.4 & 372 & 1 & 1 \\
\hline 11 & $90 \mathrm{~B}$ & 127.9 & 64.0 & 13.0 & 1 & 1 & 5 & 1.0 & 1 & 2 & 3 & 1.0 & 8 & 1849 & 2.2 & 300 & 1 & 1 \\
\hline 11 & $90 \mathrm{D}$ & 141.3 & 56.7 & 7.7 & 1 & 1 & 5 & 2.0 & 1 & 2 & 4 & 2.5 & 9 & 1975 & 1.0 & 632 & 1 & 1 \\
\hline 11 & $90 \mathrm{E}$ & 90.4 & 54.3 & 6.1 & 1 & 1 & 4 & 1.0 & 1 & 4 & 3 & 2.0 & 7 & 1986 & 1.1 & 350 & 1 & 1 \\
\hline 11 & $90 \mathrm{~F}$ & 72.0 & 54.9 & 6.6 & 1 & 1 & 3 & 1.5 & 1 & 1 & 3 & 2.0 & 7 & 1974 & 1.0 & 360 & 1 & 1 \\
\hline 11 & 91 & 99.9 & 47.3 & 3.5 & 1 & 1 & 4 & 1.0 & 1 & 2 & 4 & 2.0 & 9 & 1900 & 1.9 & 425 & 1 & 1 \\
\hline 11 & 92 & 7.2 & 53.4 & 5.5 & 1 & 1 & 2 & 1.0 & 1 & 1 & 0 & 0.0 & 1 & 1968 & 0.2 & 850 & & 1 \\
\hline 11 & 93 & 54.3 & 57.8 & 26.3 & 1 & 1 & 3 & 1.0 & 1 & 4 & 2 & 1.0 & 4 & 1964 & 0.8 & 1300 & & 1 \\
\hline 11 & $93 \mathrm{~A}$ & 104.4 & 79.0 & 37.9 & 1 & 1 & 5 & 1.0 & 1 & 2 & 3 & 1.5 & 7 & 1800 & 1.2 & 1550 & & 1 \\
\hline 11 & 93B & 79.6 & 52.2 & 4.7 & 1 & 1 & 3 & 1.0 & 1 & 4 & 2 & 2.0 & 5 & 1978 & 1.4 & 337 & & 1 \\
\hline 11 & 94 & 72.1 & 52.2 & 4.7 & 1 & 1 & 3 & 1.0 & 1 & 2 & 2 & 1.5 & 4 & 1983 & 1.0 & 1660 & & 1 \\
\hline 11 & $94 A$ & 100.8 & 52.0 & 4.6 & 1 & 1 & 4 & 1.0 & 1 & 2 & 2 & 1.5 & 5 & 1980 & 1.4 & 474 & & 1 \\
\hline 11 & 94B & 146.5 & 52.4 & 4.9 & 1 & 1 & 5 & 2.0 & 1 & 2 & 3 & 2.5 & 9 & 1984 & 1.5 & 357 & & 1 \\
\hline 11 & 95 & 0.0 & 52.9 & 10.8 & 13 & 1 & & 0.0 & & & & 0.0 & & & 0.0 & 800 & & 1 \\
\hline 11 & 96 & 80.4 & 43.5 & 2.7 & 1 & 1 & 5 & 1.0 & 1 & 1 & 3 & 1.0 & 7 & 1800 & 1.1 & 231 & & 1 \\
\hline 11 & 98 & 100.1 & 56.2 & 7.4 & 1 & 1 & 5 & 1.5 & 1 & 2 & 3 & 1.0 & 5 & 1975 & 1.1 & 601 & & 1 \\
\hline 11 & 100 & 68.9 & 52.7 & 5.0 & 1 & 1 & 3 & 1.0 & 1 & 2 & 3 & 1.0 & 7 & 1960 & 1.1 & 400 & 1 & 1 \\
\hline 11 & 101 & 128.5 & 63.1 & 12.4 & 1 & 1 & 4 & 1.0 & 1 & 2 & 4 & 3.0 & 1 & 1976 & 2.1 & 551 & 1 & 1 \\
\hline 11 & 102 & 124.7 & 44.6 & 3.1 & 1 & 1 & 4 & 1.5 & 1 & 2 & 2 & 2.0 & 4 & 1984 & 1.7 & 750 & & 1 \\
\hline 11 & 103 & 0.0 & 9.8 & 4.5 & 13 & 1 & & 0.0 & & & & 0.0 & & & 0.0 & 700 & & \\
\hline
\end{tabular}




\begin{tabular}{|c|c|c|c|c|c|c|c|c|c|c|c|c|c|c|c|c|c|c|}
\hline Map & Lot & $\begin{array}{l}\text { Bldg. } \\
\text { Value }\end{array}$ & $\begin{array}{l}\text { Land } \\
\text { Value }\end{array}$ & Acres & $\begin{array}{l}\text { Land } \\
\text { Use }\end{array}$ & Zoning & $\begin{array}{l}\text { Bldg. } \\
\text { Grade }\end{array}$ & $\begin{array}{l}\text { \# of } \\
\text { Stories }\end{array}$ & $\begin{array}{l}\text { Occu- } \\
\text { pancy }\end{array}$ & $\begin{array}{l}\text { Heat } \\
\text { Type }\end{array}$ & $\begin{array}{l}\text { of } \\
\text { Beds }\end{array}$ & $\begin{array}{l}\text { of } \\
\text { Baths }\end{array}$ & $\begin{array}{l}\text { Total } \\
\text { Rooms }\end{array}$ & $\begin{array}{l}\text { Year } \\
\text { Built }\end{array}$ & $\begin{array}{l}\text { 1st } \\
\text { Floor }\end{array}$ & Frontage & $\begin{array}{l}\text { Wet- } \\
\text { lands }\end{array}$ & $\begin{array}{l}\text { Water- } \\
\text { shed }\end{array}$ \\
\hline 11 & 104 & 80.2 & 73.5 & 29.0 & 1 & 1 & 4 & 1.0 & 1 & 2 & 5 & 1.0 & 8 & 1840 & 1.1 & 2400 & 1 & 1 \\
\hline 11 & 106 & 0.0 & 70.2 & 53.0 & 13 & 1 & & 0.0 & & & & 0.0 & & & 0.0 & 1100 & 1 & 1 \\
\hline 11 & 108 & 55.6 & 52.1 & 4.6 & 1 & 1 & 3 & 1.0 & 1 & 2 & 2 & 1.0 & 4 & 1940 & 0.8 & 820 & & 1 \\
\hline 11 & $108 \mathrm{~A}$ & 67.1 & 52.1 & 4.6 & 1 & 1 & 3 & 1.0 & 1 & 2 & 3 & 1.0 & 5 & 1976 & 1.1 & & & 1 \\
\hline 11 & 109 & 0.0 & 0.0 & 0.0 & 1 & 1 & 3 & 1.0 & 1 & 2 & 2 & 1.0 & 5 & 1945 & 1.0 & & & 1 \\
\hline 11 & 109 & 140.3 & 56.5 & 7.5 & 1 & 1 & 5 & 1.5 & 1 & 2 & 4 & 2.0 & 8 & 1845 & 1.2 & 916 & & 1 \\
\hline 11 & 110 & 0.0 & 10.0 & 4.6 & 13 & 1 & & 0.0 & & & & 0.0 & & & 0.0 & 1150 & 1 & 1 \\
\hline 11 & 111 & 0.0 & 53.2 & 15.0 & 13 & 1 & & 0.0 & & & & 0.0 & & & 0.0 & 1400 & & 1 \\
\hline 11 & 112 & 166.0 & 71.6 & 26.8 & 1 & 1 & 7 & 1.5 & 1 & 2 & 4 & 2.0 & 9 & 1800 & 1.5 & 750 & 1 & 1 \\
\hline 11 & 113 & 116.5 & 61.5 & 11.2 & 1 & 1 & 5 & 2.0 & 1 & 2 & 2 & 2.0 & 7 & 1977 & 1.2 & 400 & 1 & 1 \\
\hline 12 & 1 & 85.9 & 54.7 & 8.0 & 1 & 1 & 3 & 1.0 & 1 & 2 & 2 & 1.0 & 4 & 1955 & 2.2 & 456 & 1 & 1 \\
\hline 12 & $1 \mathrm{~A}$ & 68.0 & 52.2 & 5.0 & 1 & 1 & 3 & 1.0 & 1 & 2 & 3 & 1.0 & 6 & 1974 & 1.2 & 300 & 1 & 1 \\
\hline 12 & 1B & 0.0 & 38.0 & 3.0 & 13 & 1 & & 0.0 & & & & 0.0 & & & 0.0 & 342 & 1 & 1 \\
\hline 12 & 2 & 59.7 & 33.1 & 0.7 & 1 & 1 & 3 & 1.0 & 1 & 2 & 3 & 1.0 & 6 & 1968 & 1.2 & 188 & 1 & 1 \\
\hline 12 & 3 & 96.4 & 52.8 & 6.5 & 1 & 1 & 4 & 1.5 & 1 & 2 & 2 & 1.0 & 6 & 1938 & 1.4 & 787 & 1 & 1 \\
\hline 12 & 4 & 0.0 & 76.6 & 63.0 & 13 & 1 & & 0.0 & & & & 0.0 & & & 0.0 & 346 & 1 & 1 \\
\hline 12 & 5 & 117.9 & 77.6 & 35.0 & 1 & 1 & 5 & 1.5 & 1 & 2 & 3 & 1.0 & 10 & 1812 & 1.7 & 750 & & 1 \\
\hline 12 & 5 & 0.0 & 0.0 & 0.0 & 1 & 1 & 3 & 1.0 & 1 & 2 & 3 & 1.0 & 5 & 1969 & 0.7 & & & 1 \\
\hline 12 & 6 & 0.0 & 0.0 & 0.0 & 6 & 1 & 2 & 1.0 & 1 & 2 & 0 & 1.0 & 1 & 1972 & 0.3 & 1755 & & 1 \\
\hline 12 & 6 & 39.9 & 52.2 & 4.6 & 6 & 1 & 2 & 0.0 & 0 & 2 & 0 & 0.0 & 0 & 1968 & 1.7 & 1755 & & 1 \\
\hline 12 & $6 A$ & 65.4 & 52.6 & 5.0 & 1 & 1 & 3 & 1.0 & 1 & 1 & 2 & 1.0 & 6 & 1981 & 1.1 & 1543 & & 1 \\
\hline 12 & 7 & 0.0 & 87.7 & 70.0 & 13 & 1 & & 0.0 & & & & 0.0 & & & 0.0 & 1900 & & 1 \\
\hline 12 & 8 & 0.0 & 44.6 & 5.0 & 13 & 1 & & 0.0 & & & & 0.0 & & & 0.0 & 1000 & & 1 \\
\hline 12 & 9 & 83.2 & 44.4 & 3.0 & 1 & 1 & 4 & 1.0 & 1 & 2 & 4 & 2.0 & 8 & 1800 & 1.2 & 400 & & 1 \\
\hline 12 & 10 & 148.1 & 56.5 & 7.6 & 1 & 1 & 4 & 1.5 & 1 & 2 & 4 & 2.0 & 10 & 1984 & 1.8 & 152 & & 1 \\
\hline 12 & 11 & 0.0 & 10.5 & 4.0 & 13 & 1 & & 0.0 & & & & 0.0 & & & 0.0 & 438 & & 1 \\
\hline 12 & 12 & 0.0 & 252.0 & 24.0 & 10 & 1 & & 0.0 & & & & 0.0 & & & 0.0 & 1300 & 1 & 1 \\
\hline 12 & 13 & 90.2 & 48.8 & 4.0 & 1 & 1 & 4 & 1.5 & 1 & 2 & 3 & 2.0 & 7 & 1864 & 1.1 & 572 & & 1 \\
\hline 12 & $13 \mathrm{AE}$ & 0.0 & 0.3 & 0.0 & 10 & 1 & & 0.0 & & & & 0.0 & & & 0.0 & & & 1 \\
\hline 12 & 14 & 83.3 & 47.3 & 3.5 & 1 & 1 & 3 & 1.0 & 1 & 2 & 3 & 2.0 & 7 & 1965 & 1.4 & 500 & & 1 \\
\hline 12 & 15 & 0.0 & 84.7 & 84.3 & 13 & 1 & & 0.0 & & & & 0.0 & & & 0.0 & 1300 & 1 & 1 \\
\hline 12 & 16 & 97.0 & 41.2 & 2.3 & 1 & 1 & 3 & 1.0 & 1 & 2 & 3 & 3.5 & 9 & 1968 & 1.6 & 450 & & 1 \\
\hline 12 & 17 & 0.0 & 3.6 & 0.2 & 13 & 1 & & 0.0 & & & & 0.0 & & & 0.0 & 100 & & 1 \\
\hline 12 & 18 & 150.4 & 99.7 & 108.0 & 1 & 1 & 5 & 1.5 & 1 & 2 & 3 & 2.5 & 9 & 1850 & 1.9 & 800 & 1 & 1 \\
\hline 12 & $18 \mathrm{~A}$ & 82.6 & 52.1 & 4.7 & 1 & 1 & 3 & 1.0 & 1 & 2 & 3 & 2.0 & 7 & 1974 & 1.5 & 300 & & 1 \\
\hline 12 & 19 & 47.2 & 35.3 & 0.9 & $i$ & 1 & 3 & 1.0 & 1 & 2 & 3 & 1.0 & 5 & 1960 & 1.0 & 200 & & $i$ \\
\hline 12 & 20 & 16.3 & 75.0 & 51.0 & 12 & 1 & & 0.0 & & & & 0.0 & & & 0.0 & 911 & 1 & 1 \\
\hline 12 & $20 \mathrm{~A}$ & 66.2 & 52.6 & 5.0 & 1 & $i$ & 3 & 1.5 & 1 & 2 & 3 & 1.0 & 6 & 1979 & 0.9 & 300 & & 1 \\
\hline 12 & 21 & 0.0 & 3.2 & 8.0 & 13 & 1 & & 0.0 & & & & 0.0 & & & 0.0 & 0 & & 1 \\
\hline 12 & 22 & 0.0 & 2.0 & 5.0 & 13 & 1 & & 0.0 & & & & 0.0 & & & 0.0 & 0 & & 1 \\
\hline
\end{tabular}




\begin{tabular}{|c|c|c|c|c|c|c|c|c|c|c|c|c|c|c|c|c|c|c|}
\hline Map & Lot & $\begin{array}{l}\text { Bldg. } \\
\text { Value }\end{array}$ & $\begin{array}{l}\text { Land } \\
\text { Value }\end{array}$ & Acres & $\begin{array}{l}\text { Land } \\
\text { Use }\end{array}$ & Zoning & $\begin{array}{l}\text { Bldg. } \\
\text { Grade }\end{array}$ & $\begin{array}{l}\text { of } \\
\text { Stories }\end{array}$ & $\begin{array}{l}\text { Occu- } \\
\text { pancy }\end{array}$ & $\begin{array}{l}\text { Heat } \\
\text { Type }\end{array}$ & $\begin{array}{l}\text { of } \\
\text { Beds }\end{array}$ & $\begin{array}{l}\text { of } \\
\text { Baths }\end{array}$ & $\begin{array}{l}\text { Total } \\
\text { Rooms }\end{array}$ & $\begin{array}{l}\text { Year } \\
\text { Built }\end{array}$ & $\begin{array}{l}\text { 1st } \\
\text { Floor }\end{array}$ & Frontage & $\begin{array}{l}\text { Wet- } \\
\text { lands }\end{array}$ & $\begin{array}{l}\text { Water } \\
\text { shed }\end{array}$ \\
\hline 12 & 23 & 0.5 & 63.4 & 23.0 & 12 & 1 & & 0.0 & & & & 0.0 & & & 0.0 & 725 & & 1 \\
\hline 12 & 24 & 85.5 & 54.7 & 7.5 & 1 & 1 & 3 & 1.0 & 1 & 2 & 2 & 2.0 & 7 & 1951 & 1.9 & 495 & & 1 \\
\hline 12 & 25 & 70.9 & 93.1 & 62.2 & 1 & 1 & 3 & 1.5 & 1 & 2 & 3 & 1.5 & 7 & 1800 & 0.9 & 1295 & & 1 \\
\hline 12 & $25 \mathrm{~A}$ & 101.9 & 56.5 & 7.6 & 1 & 1 & 3 & 2.0 & 1 & 2 & 3 & 2.5 & 8 & 1959 & 1.4 & 772 & & 1 \\
\hline 12 & 26 & 99.6 & 53.8 & 9.0 & 1 & 1 & 3 & 1.0 & 1 & 2 & 2 & 1.0 & 8 & 1819 & 1.8 & 212 & & 1 \\
\hline 12 & 27 & 52.3 & 34.5 & 0.7 & 1 & 1 & 3 & 1.0 & 1 & 2 & 2 & 1.0 & 4 & 1960 & 0.8 & 140 & & 1 \\
\hline 12 & 28 & 72.9 & 53.4 & 8.0 & 1 & 1 & 4 & 1.0 & 1 & 2 & 5 & 1.0 & 10 & 1838 & 1.4 & 600 & & 1 \\
\hline 12 & $29 \mathrm{~A}$ & 82.3 & 52.4 & 4.9 & 1 & 1 & 3 & 1.5 & 1 & 2 & 3 & 1.5 & 6 & 1976 & 1.1 & & & 1 \\
\hline 12 & $29 \mathrm{~B}$ & 0.0 & 13.4 & 8.9 & 13 & 1 & & 0.0 & & & & 0.0 & & & 0.0 & & & 1 \\
\hline 12 & $29 \mathrm{C}$ & 85.8 & 36.5 & 1.0 & 1 & 1 & 3 & 1.0 & 1 & 2 & 3 & 1.0 & 8 & 1952 & 1.9 & & & 1 \\
\hline 12 & 29D & 0.0 & 0.0 & 0.0 & 1 & 1 & 2 & 1.0 & 1 & 2 & 1 & 1.0 & 5 & 1942 & 0.7 & & & 1 \\
\hline 12 & 29D & 111.3 & 56.0 & 7.2 & 1 & 1 & 4 & 2.0 & 1 & 2 & 1 & 1.0 & 3 & 1942 & 1.3 & & & 1 \\
\hline 12 & $29 \mathrm{E}$ & 110.4 & 60.3 & 10.1 & 1 & 1 & 4 & 2.0 & 1 & 2 & 3 & 1.0 & 6 & 1979 & 0.9 & & & 1 \\
\hline 12 & $29 \mathrm{~F}$ & 100.8 & 57.1 & 8.0 & 1 & 1 & 4 & 2.0 & 1 & 2 & 3 & 1.5 & 7 & 1981 & 1.1 & & & 1 \\
\hline 12 & 30 & 0.0 & 0.0 & 0.0 & 1 & 1 & 3 & 1.5 & 1 & 2 & 2 & 1.0 & 5 & 1838 & 0.8 & & & 1 \\
\hline 12 & 30 & 111.0 & 72.1 & 27.3 & 1 & 1 & 3 & 1.5 & 1 & 2 & 3 & 1.0 & 6 & 1880 & 1.0 & 1075 & 1 & 1 \\
\hline 12 & 31 & 96.2 & 58.6 & 9.0 & 2 & 1 & 3 & 1.0 & 2 & 4 & 5 & 2.0 & 9 & 1963 & 2.2 & 650 & & 1 \\
\hline 12 & 32 & 106.6 & 38.5 & 1.7 & 1 & 1 & 3 & 2.0 & 1 & 2 & 3 & 2.0 & 6 & 1982 & 1.0 & 150 & & 1 \\
\hline 12 & 33 & 62.4 & 37.6 & 1.3 & 1 & 1 & 3 & 1.0 & 1 & 2 & 2 & 1.0 & 5 & 1974 & 0.8 & 225 & & 1 \\
\hline 12 & 34 & 96.0 & 65.8 & 19.0 & 33 & 1 & 5 & 1.0 & 1 & 2 & 4 & 1.0 & 7 & 1878 & 1.2 & 850 & 1 & 1 \\
\hline 12 & 35 & 89.0 & 52.9 & 5.5 & 1 & 1 & 5 & 1.0 & 1 & 1 & 4 & 1.0 & 11 & 1840 & 1.5 & 325 & & 1 \\
\hline 12 & 36 & 107.5 & 41.2 & 2.3 & 1 & 1 & 4 & 1.0 & 1 & 2 & 3 & 2.0 & 6 & 1986 & 1.7 & 300 & & 1 \\
\hline 12 & 37 & 77.3 & 57.1 & 8.0 & 1 & 1 & 3 & 1.5 & 1 & 3 & 2 & 2.0 & 5 & 1986 & 0.9 & 400 & & 1 \\
\hline 12 & 38 & 0.0 & 2.6 & 0.1 & 78 & 1 & & 0.0 & & & & 0.0 & & & 0.0 & 86 & & 1 \\
\hline 12 & 39 & 0.0 & 840.0 & 80.0 & 10 & 1 & & 0.0 & & & & 0.0 & & & 0.0 & 3100 & 1 & 1 \\
\hline 12 & 40 & 19.3 & 104.7 & 87.0 & 1 & 1 & 2 & 1.0 & 1 & 1 & 1 & 0.0 & 4 & 1940 & 0.5 & 350 & 1 & 1 \\
\hline 12 & 41 & 88.8 & 105.4 & 8.0 & 1 & 1 & 3 & 1.0 & 1 & 2 & 4 & 2.0 & 6 & 1969 & 1.6 & 80 & 1 & 1 \\
\hline 12 & $41 \mathrm{~A}$ & 74.3 & 97.0 & 9.4 & 1 & 1 & 4 & 2.0 & 1 & 4 & 2 & 1.0 & 5 & 1984 & 0.8 & 25 & & 1 \\
\hline 12 & 42 & 50.1 & 40.8 & 0.3 & 1 & 1 & 3 & 1.0 & 1 & 4 & 1 & 1.0 & 3 & 1985 & 0.6 & & & 1 \\
\hline 12 & $42 \mathrm{~A}$ & 63.9 & 52.7 & 0.5 & 1 & 1 & 3 & 2.0 & 1 & 2 & 3 & 1.5 & 7 & 1950 & 0.5 & & & 1 \\
\hline 12 & 43 & 57.2 & 36.6 & 1.0 & 1 & 1 & 3 & 1.0 & 1 & 2 & 4 & 1.0 & 8 & 1935 & 1.0 & 150 & & 1 \\
\hline 12 & 44 & 58.8 & 30.3 & 0.5 & 1 & 1 & 3 & 1.0 & 1 & 2 & 3 & 1.5 & 5 & 1962 & 1.3 & 125 & & 1 \\
\hline 12 & 45 & 45.8 & 33.0 & 0.8 & 1 & 1 & 2 & 1.0 & 1 & 2 & 2 & 1.0 & 6 & 1955 & 0.9 & 200 & & 1 \\
\hline 12 & 46 & 0.0 & 4.0 & 0.3 & 13 & 1 & & 0.0 & & & & 0.0 & & & 0.0 & 75 & 1 & 1 \\
\hline 12 & 47 & 0.0 & 151.2 & 144.0 & 10 & 1 & & 0.0 & & & & 0.0 & & & 0.0 & 2050 & 1 & 1 \\
\hline 12 & 48 & 35.6 & 36.6 & 1.0 & 1 & 1 & 3 & 1.5 & 1 & 2 & 3 & 2.0 & 7 & 1989 & 1.0 & 100 & & 1 \\
\hline 12 & 49 & 68.2 & 36.6 & 1.0 & 1 & 1 & 3 & 1.0 & 1 & 2 & 3 & 1.0 & 5 & 1988 & 1.1 & 100 & & 1 \\
\hline 12 & 50 & 69.7 & 45.3 & 3.3 & 1 & 1 & 3 & 1.5 & 1 & 2 & 2 & 2.0 & 6 & 1938 & 0.9 & 375 & & 1 \\
\hline 12 & 51 & 0.0 & 32.0 & 1.5 & 13 & 1 & & 0.0 & & & & 0.0 & & & 0.0 & 150 & & 1 \\
\hline 12 & 52 & 74.9 & 33.0 & 0.8 & 1 & 1 & 3 & 1.0 & 1 & 2 & 3 & 1.0 & 6 & 1962 & 1.0 & 350 & & 1 \\
\hline
\end{tabular}




\begin{tabular}{|c|c|c|c|c|c|c|c|c|c|c|c|c|c|c|c|c|c|c|}
\hline Map & Lot & $\begin{array}{l}\text { Bldg. } \\
\text { Value }\end{array}$ & $\begin{array}{l}\text { Land } \\
\text { Value }\end{array}$ & Acres & $\begin{array}{l}\text { Land } \\
\text { Use }\end{array}$ & Zoning & $\begin{array}{l}\text { Bldg. } \\
\text { Grade }\end{array}$ & $\begin{array}{l}\text { \# of } \\
\text { Stories }\end{array}$ & $\begin{array}{l}\text { Occu- } \\
\text { pancy }\end{array}$ & $\begin{array}{l}\text { Heat } \\
\text { Type }\end{array}$ & $\begin{array}{l}\text { \#of } \\
\text { Beds }\end{array}$ & $\begin{array}{l}\text { of } \\
\text { Baths }\end{array}$ & $\begin{array}{l}\text { Total } \\
\text { Rooms }\end{array}$ & $\begin{array}{l}\text { Year } \\
\text { Built }\end{array}$ & $\begin{array}{l}\text { 1st } \\
\text { Floor }\end{array}$ & Frontage & $\begin{array}{l}\text { Wet- } \\
\text { lands }\end{array}$ & $\begin{array}{l}\text { Water- } \\
\text { shed }\end{array}$ \\
\hline 12 & 53 & 58.6 & 38.0 & 1.5 & 1 & 1 & 3 & 1.0 & 1 & 2 & 3 & 1.0 & 6 & 1929 & 0.8 & 530 & & 1 \\
\hline 12 & $53 \mathrm{~A}$ & 0.0 & 31.4 & 1.2 & 13 & 1 & & 0.0 & & & & 0.0 & & & 0.0 & & & 1 \\
\hline 12 & 54 & 0.0 & 68.6 & 34.3 & 13 & 1 & & 0.0 & & & & 0.0 & & & 0.0 & 825 & & 1 \\
\hline 12 & $54 \mathrm{~A}$ & 0.0 & 44.6 & 5.0 & 13 & 1 & & 0.0 & & & & 0.0 & & & 0.0 & 425 & & 1 \\
\hline 12 & $54 \mathrm{Al}$ & 0.0 & 44.6 & 5.0 & 13 & 1 & & 0.0 & & & & 0.0 & & & 0.0 & 300 & & 1 \\
\hline 12 & $54 \mathrm{~A} 2$ & 86.3 & 64.0 & 13.0 & 1 & 1 & 3 & 2.0 & 1 & 2 & 3 & 1.5 & 5 & 1981 & 0.8 & 300 & & 1 \\
\hline 12 & 55 & 103.4 & 63.6 & 12.7 & 1 & 1 & 3 & 1.0 & 1 & 2 & 2 & 1.5 & 4 & 1979 & 1.0 & 1050 & & 1 \\
\hline 12 & $55 \mathrm{~A}$ & 0.0 & 60.7 & 18.0 & 13 & 1 & & 0.0 & & & & 0.0 & & & 0.0 & 900 & & 1 \\
\hline 12 & 56 & 0.0 & 6.0 & 4.0 & 13 & 1 & & 0.0 & & & & 0.0 & & & 0.0 & 0 & & 1 \\
\hline 12 & 57 & 79.0 & 55.2 & 6.8 & 1 & 1 & 3 & 1.5 & 1 & 2 & 2 & 2.0 & 7 & 1958 & 1.1 & 1043 & & 1 \\
\hline 12 & 59 & 0.0 & 42.7 & 4.5 & 13 & 1 & & 0.0 & & & & 0.0 & & & 0.0 & 350 & & 1 \\
\hline 12 & 60 & 0.0 & 54.5 & 11.9 & 13 & 1 & & 0.0 & & & & 0.0 & & & 0.0 & 1502 & & 1 \\
\hline 12 & 61 & 115.5 & 69.4 & 21.0 & 1 & 1 & 5 & 2.0 & 1 & 2 & 5 & 1.0 & 10 & 1747 & 1.2 & 1800 & & 1 \\
\hline 12 & 62 & 0.0 & 115.5 & 11.0 & 10 & 1 & & 0.0 & & & & 0.0 & & & 0.0 & 2800 & & 1 \\
\hline 12 & 63 & 0.0 & 0.5 & 0.2 & 13 & 1 & & 0.0 & & & & 0.0 & & & 0.0 & 125 & & 1 \\
\hline 12 & 64 & 0.4 & 34.0 & 2.0 & 12 & 1 & & 0.0 & & & & 0.0 & & & 0.0 & 400 & & 1 \\
\hline 12 & 65 & 96.8 & 68.0 & 21.0 & 1 & 1 & 5 & 1.0 & 1 & 2 & 3 & 1.0 & 8 & 1800 & 1.2 & 2327 & & 1 \\
\hline 12 & 66 & 0.0 & 5061.0 & 482.0 & 10 & 1 & & 0.0 & & & & 0.0 & & & 0.0 & 2100 & & 1 \\
\hline 12 & 67 & 20.8 & 54.5 & 6.3 & 1 & 1 & 3 & 1.0 & 1 & 1 & 0 & 0.0 & 2 & 1941 & 0.5 & 1307 & & 1 \\
\hline 12 & $67 A$ & 0.0 & 6.3 & 1.1 & 10 & 1 & & 0.0 & & & & 0.0 & & & 0.0 & & & 1 \\
\hline 12 & $67 \mathrm{~B}$ & 69.0 & 54.2 & 6.1 & 1 & 1 & 3 & 1.0 & 1 & 2 & 1 & 1.0 & 4 & 1983 & 0.8 & 424 & & 1 \\
\hline 12 & $67 \mathrm{C}$ & 130.3 & 54.2 & 6.0 & 1 & 1 & 4 & 2.0 & 1 & 2 & 3 & 2.0 & 6 & 1987 & 1.2 & 523 & & 1 \\
\hline 12 & 68 & 50.6 & 75.0 & 35.0 & 1 & 1 & 2 & 1.0 & 1 & 1 & 2 & 1.0 & 3 & 1975 & 1.0 & 3100 & 1 & 1 \\
\hline 12 & 69 & 0.0 & 53.2 & 12.0 & 13 & 1 & & 0.0 & & & & 0.0 & & & 0.0 & 500 & 1 & 1 \\
\hline 12 & 70 & 84.2 & 173.2 & 30.0 & 6 & 1 & 3 & 0.0 & & 2 & & 0.0 & & 1960 & 0.7 & 2500 & 1 & 1 \\
\hline 12 & 70 & 0.0 & 0.0 & 0.0 & 6 & 1 & 3 & 0.0 & & 2 & & 0.0 & & 1960 & 0.7 & & & 1 \\
\hline 12 & 70 & 0.0 & 0.0 & 0.0 & 6 & 1 & 1 & 0.0 & & 2 & & 0.0 & & 1950 & 1.3 & & & 1 \\
\hline 12 & 70 & 0.0 & 0.0 & 0.0 & 6 & 1 & 2 & 0.0 & & 2 & & 0.0 & & 1950 & 2.1 & & & 1 \\
\hline 12 & 71 & 2.6 & 75.3 & 32.0 & 5 & 1 & & 0.0 & & & & 0.0 & & & 0.0 & 1550 & 1 & 1 \\
\hline 12 & $71 \mathrm{~A}$ & 69.2 & 36.6 & 1.0 & 72 & 1 & 3 & 1.5 & 1 & 1 & 3 & 2.0 & 6 & 1790 & 1.8 & & & 1 \\
\hline 12 & 72 & 174.9 & 85.0 & 52.0 & 1 & 1 & 6 & 2.0 & 1 & 2 & 2 & 2.5 & 8 & 1812 & 1.5 & 900 & 1 & 1 \\
\hline 13 & 1 & 0.0 & 32.4 & 1.5 & 13 & 1 & & 0.0 & & & & 0.0 & & & 0.0 & 650 & & \\
\hline 13 & 2 & 0.0 & 31.9 & 1.4 & 13 & 1 & & 0.0 & & & & 0.0 & & & 0.0 & 650 & & \\
\hline 13 & $2 A$ & 0.0 & 41.7 & 3.8 & 13 & 1 & & 0.0 & & & & 0.0 & & & 0.0 & & & \\
\hline 13 & 3 & 112.3 & 52.1 & 4.6 & 1 & 1 & 4 & 2.0 & 1 & 2 & 3 & 2.5 & 7 & 1987 & 1.0 & 300 & & \\
\hline 13 & $3 A$ & 0.0 & 48.2 & 7.4 & 13 & 1 & & 0.0 & & & & 0.0 & & & 0.0 & 300 & & \\
\hline 13 & $3 B$ & 84.2 & 57.7 & 8.4 & 1 & 1 & 3 & 2.0 & 1 & 2 & 3 & 2.0 & 5 & 1987 & 0.8 & 300 & & \\
\hline 13 & $3 C$ & 150.0 & 56.0 & 7.2 & 1 & 1 & 4 & 2.0 & 1 & 3 & 4 & 2.5 & 8 & 1987 & 1.5 & 300 & & \\
\hline 13 & $3 D$ & 129.3 & 54.6 & 6.3 & 1 & 1 & 4 & 2.0 & 1 & 2 & 3 & 2.5 & 7 & 1988 & 1.1 & 305 & & \\
\hline 13 & $3 E$ & 69.2 & 53.5 & 5.6 & 1 & 1 & 3 & 1.0 & 1 & 2 & 3 & 1.0 & 6 & 1987 & 1.1 & 300 & & \\
\hline
\end{tabular}




\begin{tabular}{|c|c|c|c|c|c|c|c|c|c|c|c|c|c|c|c|c|c|c|}
\hline Map & Lot & $\begin{array}{l}\text { Bldg. } \\
\text { Value }\end{array}$ & $\begin{array}{l}\text { Land } \\
\text { Value }\end{array}$ & Acres & $\begin{array}{l}\text { Land } \\
\text { Use }\end{array}$ & Zoning & $\begin{array}{l}\text { Bldg. } \\
\text { Grade }\end{array}$ & $\begin{array}{l}\text { \# of } \\
\text { Stories }\end{array}$ & $\begin{array}{l}\text { Occu- } \\
\text { pancy }\end{array}$ & $\begin{array}{l}\text { Heat } \\
\text { Type }\end{array}$ & $\begin{array}{l}\text { \# of } \\
\text { Beds }\end{array}$ & $\begin{array}{l}\text { \# of } \\
\text { Baths }\end{array}$ & $\begin{array}{l}\text { Total } \\
\text { Rooms }\end{array}$ & $\begin{array}{l}\text { Year } \\
\text { Built }\end{array}$ & $\begin{array}{l}\text { 1st } \\
\text { Floor }\end{array}$ & Frontage & $\begin{array}{l}\text { Wet- } \\
\text { lands }\end{array}$ & $\begin{array}{l}\text { Water- } \\
\text { shed }\end{array}$ \\
\hline 13 & $3 F$ & 97.6 & 52.1 & 4.6 & 1 & 1 & 4 & 1.5 & 1 & 2 & 2 & 1.5 & 6 & 1987 & 0.9 & 300 & & \\
\hline 13 & $3 \mathbf{G}$ & 82.9 & 52.1 & 4.6 & 1 & 1 & 3 & 1.0 & 1 & 2 & 3 & 2.0 & 5 & 1988 & $1.4^{\circ}$ & 602 & & \\
\hline 13 & 4 & 83.1 & 36.6 & 1.0 & 1 & 1 & 3 & 1.5 & 1 & 2 & 3 & 1.5 & 7 & 1800 & 1.0 & 180 & & \\
\hline 13 & 5 & 108.2 & 122.8 & 177.0 & 1 & 1 & 3 & 1.0 & 1 & 4 & 1 & 1.0 & 2 & 1980 & 0.7 & 1300 & & \\
\hline 13 & 6 & 41.6 & 40.1 & 2.0 & 1 & 1 & 2 & 1.0 & 1 & 1 & 1 & 1.0 & 4 & 1969 & 1.0 & 250 & & \\
\hline 13 & 7 & 0.0 & 77.3 & 48.0 & 13 & 1 & & 0.0 & & & & 0.0 & & & 0.0 & 1250 & 1 & \\
\hline 13 & 8 & 61.0 & 46.6 & 3.5 & 1 & 1 & 3 & 1.0 & 1 & 2 & 2 & 1.0 & 5 & 1950 & 1.1 & 445 & & \\
\hline 13 & 9 & 67.3 & 71.9 & 24.0 & 1 & 1 & 3 & 1.5 & 1 & 2 & 3 & 1.5 & 7 & 1943 & 0.8 & 670 & & \\
\hline 13 & 10 & 96.2 & 44.4 & 3.0 & 1 & 1 & 3 & 2.0 & 1 & 2 & 3 & 2.0 & 7 & 1983 & 1.0 & 330 & & 1 \\
\hline 13 & 11 & 85.4 & 36.9 & 1.1 & 1 & 1 & 3 & 1.5 & 1 & 2 & 3 & 1.5 & 8 & 1965 & 1.2 & 208 & & 1 \\
\hline 13 & 12 & 0.0 & 67.4 & 30.1 & 13 & 1 & & 0.0 & & & & 0.0 & & & 0.0 & 606 & 1 & 1 \\
\hline 13 & 13 & 87.7 & 88.5 & 54.0 & 1 & 1 & 4 & 2.0 & 1 & 1 & 5 & 2.0 & 8 & 1800 & 1.2 & 930 & 1 & 1 \\
\hline 13 & $13 \mathrm{~A}$ & 90.5 & 65.0 & 13.7 & 1 & 1 & 3 & 2.0 & 1 & 4 & 3 & 1.5 & 5 & 1981 & 1.0 & 412 & 1 & 1 \\
\hline 13 & $14 \mathrm{~A}$ & 120.4 & 66.6 & 15.0 & 1 & 1 & 4 & 2.0 & 1 & 2 & 2 & 2.5 & 7 & 1985 & 1.1 & & & 1 \\
\hline 13 & 15 & 0.0 & 0.0 & 0.0 & 72 & 1 & 3 & 1.5 & 1 & 3 & 2 & 1.5 & 6 & 1965 & 1.0 & & & 1 \\
\hline 13 & 15 & 674.4 & 43.2 & 2.8 & 72 & 1 & 2 & 0.0 & & 2 & & 0.0 & & 1827 & 6.6 & 490 & & 1 \\
\hline 13 & 16 & 71.7 & 36.6 & 1.0 & 1 & 1 & 3 & 1.5 & 1 & 1 & 2 & 1.0 & 4 & 1981 & 0.7 & 256 & & 1 \\
\hline 13 & 17 & 14.3 & 87.1 & 51.7 & 11 & 1 & 2 & 1.0 & 1 & 1 & 0 & 0.0 & 2 & 1950 & 0.4 & 2079 & 1 & 1 \\
\hline 13 & 18 & 103.1 & 54.6 & 6.3 & 1 & 1 & 5 & 1.0 & 1 & 2 & 3 & 2.0 & 8 & 1799 & 1.4 & 919 & 1 & 1 \\
\hline 13 & $18 \mathrm{~A}$ & 115.1 & 60.7 & 10.6 & 1 & 1 & 4 & 2.0 & 1 & 2 & 3 & 2.0 & 7 & 1976 & 1.1 & & & 1 \\
\hline 13 & 18B & 111.3 & 52.6 & 5.0 & 1 & 1 & 4 & 1.5 & 1 & 2 & 4 & 2.0 & 7 & 1976 & 1.3 & & & 1 \\
\hline 13 & $18 \mathrm{C}$ & 0.0 & 44.6 & 5.0 & 13 & 1 & & 0.0 & & & & 0.0 & & & 0.0 & 1 & & 1 \\
\hline 13 & 18D & 57.7 & 64.1 & 13.1 & 1 & 1 & 2 & 1.0 & 1 & 4 & 2 & 1.0 & 5 & 1977 & 1.4 & & & 1 \\
\hline 13 & 19 & 0.0 & 66.2 & 27.5 & 13 & 1 & & 0.0 & & & & 0.0 & & & 0.0 & 1266 & 1 & 1 \\
\hline 13 & $19 \mathrm{~A}$ & 0.0 & 50.9 & 9.2 & 13 & 1 & & 0.0 & & & & 0.0 & & & 0.0 & 493 & 1 & 1 \\
\hline 13 & $19 \mathrm{~B}$ & 0.0 & 48.4 & 9.0 & 13 & 1 & & 0.0 & & & & 0.0 & & & 0.0 & 300 & 1 & 1 \\
\hline 13 & 20 & 56.6 & 70.7 & 23.2 & 1 & 1 & 3 & 1.0 & 1 & 2 & 3 & 1.0 & 5 & 1949 & 1.1 & 1577 & & 1 \\
\hline 13 & 21 & 58.6 & 37.4 & 1.3 & 1 & 1 & 3 & 1.0 & 1 & 2 & 1 & 1.5 & 6 & 1950 & 1.6 & 475 & & 1 \\
\hline 13 & 22 & 0.0 & 58.6 & 15.0 & 13 & 1 & & 0.0 & & & & 0.0 & & & 0.0 & 429 & 1 & 1 \\
\hline 13 & $22 \mathrm{~A}$ & 0.0 & 58.6 & 15.0 & 13 & 1 & & 0.0 & & & & 0.0 & & & 0.0 & 350 & 1 & 1 \\
\hline 13 & 23 & 0.0 & 84.7 & 62.7 & 13 & 1 & & 0.0 & & & & 0.0 & & & 0.0 & 1845 & 1 & 1 \\
\hline 13 & 24 & 129.4 & 0.0 & 0.0 & 1 & 4 & 3 & 1.0 & 1 & 2 & 5 & 2.0 & 8 & 1958 & 1.8 & & & 1 \\
\hline 13 & 24 & 81.2 & 66.6 & 5.0 & 6 & 4 & 3 & 0.0 & & 2 & & 0.0 & & 1963 & 4.0 & 1062 & & 1 \\
\hline 13 & 24 & 0.0 & 0.0 & 0.0 & 1 & 4 & 2 & 1.0 & 1 & 2 & 2 & 1.0 & 6 & 1949 & 0.8 & & & 1 \\
\hline 13 & 24 & 0.0 & 0.0 & 0.0 & 1 & 4 & 2 & 1.0 & 1 & 2 & 2 & 1.0 & 2 & 1945 & 0.8 & & & 1 \\
\hline 13 & 25 & 0.0 & 52.7 & 15.8 & 13 & 4 & & 0.0 & & & & 0.0 & & & 0.0 & 1104 & & 1 \\
\hline 13 & 26 & 0.0 & 41.8 & 4.0 & 13 & 4 & & 0.0 & & & & 0.0 & & & 0.0 & 100 & & 1 \\
\hline 13 & 27 & 30.3 & 44.0 & 4.6 & 5 & 4 & 1 & 0.0 & & 1 & & 0.0 & & 1942 & 4.7 & & & 1 \\
\hline 13 & 27 & 109.7 & 50.7 & 9.4 & 1 & 4 & 3 & 1.0 & 1 & 2 & 4 & 2.0 & 7 & 1962 & 2.1 & 250 & & 1 \\
\hline 13 & 27 & 0.0 & 0.0 & 0.0 & 1 & 4 & 1 & 1.0 & 1 & 1 & 1 & 1.0 & 4 & 1942 & 0.6 & & & 1 \\
\hline
\end{tabular}




\begin{tabular}{|c|c|c|c|c|c|c|c|c|c|c|c|c|c|c|c|c|c|c|}
\hline Map & Lot & $\begin{array}{l}\text { Bldg. } \\
\text { Value }\end{array}$ & $\begin{array}{l}\text { Land } \\
\text { Value }\end{array}$ & Acres & $\begin{array}{l}\text { Land } \\
\text { Use }\end{array}$ & Zoning & $\begin{array}{l}\text { Bldg. } \\
\text { Grade }\end{array}$ & $\begin{array}{l}\text { of } \\
\text { Stories }\end{array}$ & $\begin{array}{l}\text { Occu- } \\
\text { pancy }\end{array}$ & $\begin{array}{l}\text { Heat } \\
\text { Type }\end{array}$ & $\begin{array}{l}\text { of } \\
\text { Beds }\end{array}$ & $\begin{array}{l}\# \text { of } \\
\text { Baths }\end{array}$ & $\begin{array}{l}\text { Total } \\
\text { Rooms }\end{array}$ & $\begin{array}{l}\text { Year } \\
\text { Built }\end{array}$ & $\begin{array}{l}\text { 1st } \\
\text { Floor }\end{array}$ & Frontage & $\begin{array}{l}\text { Wet- } \\
\text { lands }\end{array}$ & $\begin{array}{l}\text { Water- } \\
\text { ahed }\end{array}$ \\
\hline 13 & 28 & 68.6 & 41.6 & 0.4 & 6 & 4 & 3 & 0.0 & & 2 & & 0.0 & & 1875 & 1.8 & 85 & & 1 \\
\hline 13 & 29 & 67.6 & 0.0 & 0.0 & 1 & 4 & 3 & 1.0 & 1 & 2 & 3 & 1.0 & 6 & 1965 & 0.9 & & & 1 \\
\hline 13 & 29 & 50.6 & 60.8 & 1.5 & 5 & 4 & 2 & 0.0 & & 1 & & 0.0 & & 1970 & 1.0 & 330 & & 1 \\
\hline 13 & 29 & 0.0 & 0.0 & 0.0 & 1 & 4 & 2 & 1.0 & 1 & 1 & 1 & 1.0 & 3 & 1900 & 0.4 & & & 1 \\
\hline 13 & $29 \mathrm{~A}$ & 86.2 & 27.4 & 0.7 & 1 & 4 & 5 & 1.0 & 1 & 2 & 3 & 2.0 & 7 & 1790 & 1.3 & 137 & & 1 \\
\hline 13 & 30 & 0.0 & 10.6 & 4.1 & 13 & 1 & & 0.0 & & & & 0.0 & & & 0.0 & 132 & & 1 \\
\hline 13 & 31 & 0.0 & 3.5 & 0.9 & 13 & 1 & & 0.0 & & & & 0.0 & & & 0.0 & 111 & & 1 \\
\hline 13 & 32 & 38.5 & 42.5 & 2.6 & 1 & 1 & 2 & 1.0 & 1 & 2 & 2 & 1.0 & 5 & 1948 & 0.8 & 270 & & 1 \\
\hline 13 & 33 & 0.0 & 1.7 & 0.7 & 13 & $i$ & & 0.0 & & & & 0.0 & & & 0.0 & 100 & & 1 \\
\hline 13 & 34 & 0.0 & 41.8 & 4.0 & 13 & 1 & & 0.0 & & & & 0.0 & & & 0.0 & 430 & & 1 \\
\hline 13 & 35 & 0.0 & 45.1 & 5.3 & 13 & 1 & & 0.0 & & & & 0.0 & & & 0.0 & 430 & & 1 \\
\hline 13 & 36 & 68.3 & 54.6 & 10.9 & 1 & 1 & 3 & 1.0 & 1 & 2 & 3 & 1.0 & 5 & 1975 & 1.2 & 870 & & 1 \\
\hline 13 & 37 & 0.0 & 142.0 & 212.0 & 13 & 1 & & 0.0 & & & & 0.0 & & & 0.0 & 950 & 1 & 1 \\
\hline 13 & $37 \mathrm{~A}$ & 0.0 & 44.1 & 4.6 & 13 & 1 & & 0.0 & & & & 0.0 & & & 0.0 & 550 & 1 & 1 \\
\hline 13 & $37 \mathrm{~B}$ & 0.0 & 7.5 & 5.0 & 15 & $i$ & & 0.0 & & & & 0.0 & & & 0.0 & & & 1 \\
\hline 13 & 38 & 0.0 & 22.0 & 13.0 & 13 & $i$ & & 0.0 & & & & 0.0 & & & 0.0 & 568 & 1 & $i$ \\
\hline 13 & 40 & 0.0 & 12.5 & 6.3 & 13 & 1 & & 0.0 & & & & 0.0 & & & 0.0 & 285 & 1 & 1 \\
\hline 13 & 41 & 0.0 & 47.6 & 7.0 & 13 & 1 & & 0.0 & & & & 0.0 & & & 0.0 & 285 & 1 & 1 \\
\hline 13 & 42 & 73.0 & 36.6 & 1.0 & 1 & 1 & 3 & 2.0 & 1 & 2 & 3 & 1.0 & 5 & 1800 & 0.9 & 481 & & $i$ \\
\hline 13 & 43 & 61.9 & 50.0 & 4.3 & 1 & $i$ & 3 & 2.0 & $i$ & 3 & 3 & 1.0 & 7 & 1932 & 0.9 & 438 & & 1 \\
\hline 13 & $43 \mathrm{~A}$ & 64.5 & 53.2 & 5.4 & $i$ & $i$ & 3 & 1.0 & $i$ & 2 & 3 & 1.0 & 5 & 1959 & 1.0 & 506 & & 1 \\
\hline 13 & 45 & 0.0 & 73.6 & 41.0 & 13 & i & & 0.0 & & & & 0.0 & & & 0.0 & 1600 & & 1 \\
\hline 13 & $45 \mathrm{~A}$ & 0.0 & 27.5 & 32.0 & 13 & 1 & & 0.0 & & & & 0.0 & & & 0.0 & 0 & & 1 \\
\hline 13 & 45B & 0.0 & 45.5 & 5.6 & 13 & 1 & & 0.0 & & & & 0.0 & & & 0.0 & & & 1 \\
\hline 13 & $45 \mathrm{C}$ & 0.0 & 45.3 & 5.5 & 13 & $i$ & & 0.0 & & & & 0.0 & & & 0.0 & & & $i$ \\
\hline 13 & 45D & 169.6 & 52.2 & 4.7 & 1 & 1 & 4 & 2.0 & 1 & 2 & 3 & 2.5 & 8 & 1988 & 1.8 & & & 1 \\
\hline 13 & $45 E$ & 84.1 & 52.8 & 5.1 & $i$ & 1 & 4 & 2.0 & i & 2 & 5 & 3.5 & 10 & 1989 & 2.0 & & & $i$ \\
\hline 13 & 46 & 0.0 & 20.7 & 20.0 & 13 & 1 & & 0.0 & & & & 0.0 & & & 0.0 & 0 & 1 & 1 \\
\hline 13 & 47 & 197.5 & 69.5 & 23.1 & 4 & 1 & 3 & 0.0 & & 2 & & 0.0 & & 1875 & 4.1 & 1330 & & 1 \\
\hline 13 & $47 A$ & 0.0 & 11.3 & 7.5 & 13 & 1 & & 0.0 & & & & 0.0 & & & 0.0 & 0 & & 1 \\
\hline 13 & $47 B$ & 0.0 & 10.9 & 7.2 & 13 & 1 & & 0.0 & & & & 0.0 & & & 0.0 & 0 & & i \\
\hline 13 & $47 \mathrm{C}$ & 0.0 & 22.0 & 20.0 & 15 & $i$ & & 0.0 & & & & 0.0 & & & 0.0 & 0 & & 1 \\
\hline 13 & $47 \mathrm{D}$ & 88.4 & 52.2 & 4.7 & 1 & 1 & 4 & 1.5 & 1 & 2 & 3 & 2.0 & 6 & 1987 & 0.9 & 300 & & 1 \\
\hline 13 & $47 E$ & 7.3 & 69.2 & 19.5 & 1 & 1 & 3 & 1.0 & 1 & 2 & 2 & 1.0 & 5 & 1970 & 0.7 & & & 1 \\
\hline 13 & 48 & 23.0 & 34.5 & 0.8 & 1 & $i$ & 2 & 1.0 & 1 & 3 & 1 & 1.0 & 3 & 1900 & 0.5 & 150 & & \\
\hline 13 & 49 & 5.8 & 37.4 & 1.3 & 1 & 1 & 3 & 1.0 & 1 & 2 & 2 & 1.0 & 4 & 1965 & 0.7 & 200 & & \\
\hline 13 & 50 & 69.8 & 51.0 & 4.5 & 1 & 1 & 3 & 1.0 & 1 & 2 & 2 & 1.0 & 4 & 1982 & 0.9 & 300 & & \\
\hline 13 & 51 & 0.0 & 22.9 & 0.4 & 13 & 1 & & 0.0 & & & & 0.0 & & & 0.0 & 150 & & \\
\hline 13 & 52 & 0.0 & 22.9 & 0.4 & 13 & $i$ & & 0.0 & & & & 0.0 & & & 0.0 & 150 & & \\
\hline 13 & 53 & 97.0 & 26.8 & 0.4 & 1 & 1 & 3 & 1.0 & 1 & 2 & 4 & 3.0 & 8 & 1960 & 1.8 & 150 & & \\
\hline
\end{tabular}




\begin{tabular}{|c|c|c|c|c|c|c|c|c|c|c|c|c|c|c|c|c|c|c|}
\hline Map & Lot & $\begin{array}{l}\text { Bldg. } \\
\text { Value }\end{array}$ & $\begin{array}{l}\text { Land } \\
\text { Value }\end{array}$ & Acres & $\begin{array}{l}\text { Land } \\
\text { Use }\end{array}$ & Zoning & $\begin{array}{l}\text { Bldg. } \\
\text { Grade }\end{array}$ & $\begin{array}{l}\text { \# of } \\
\text { Stories }\end{array}$ & $\begin{array}{l}\text { Occu- } \\
\text { pancy }\end{array}$ & $\begin{array}{l}\text { Heat } \\
\text { Type }\end{array}$ & $\begin{array}{l}\text { "of } \\
\text { Beds }\end{array}$ & $\begin{array}{l}\text { of } \\
\text { Baths }\end{array}$ & $\begin{array}{l}\text { Total } \\
\text { Rooms }\end{array}$ & $\begin{array}{l}\text { Year } \\
\text { Built }\end{array}$ & $\begin{array}{l}\text { 1st } \\
\text { Floor }\end{array}$ & Frontage & $\begin{array}{l}\text { Wet- } \\
\text { lands }\end{array}$ & $\begin{array}{l}\text { Water- } \\
\text { shed }\end{array}$ \\
\hline 13 & 54 & 69.6 & 40.1 & 2.0 & 1 & 1 & 3 & 1.0 & 1 & 2 & 3 & 1.0 & 6 & 1984 & 0.9 & 144 & & \\
\hline 13 & 55 & 0.0 & 51.4 & 9.5 & 13 & 1 & & 0.0 & & & & 0.0 & & & 0.0 & 175 & & \\
\hline 13 & 56 & 87.3 & 38.5 & 1.7 & 1 & 1 & 3 & 1.0 & 1 & 3 & 3 & 2.0 & 6 & 1986 & 1.0 & 206 & & \\
\hline 13 & 58 & 77.6 & 42.5 & 2.5 & 1 & 1 & 2 & 1.0 & 1 & 2 & 2 & 2.0 & 8 & 1968 & 1.2 & & & \\
\hline 13 & 59 & 39.4 & 36.6 & 1.0 & 1 & 1 & 2 & 1.0 & 1 & 2 & 2 & 1.0 & 5 & 1951 & 0.8 & 150 & 1 & \\
\hline 13 & 60 & 69.5 & 47.8 & 3.8 & 1 & 1 & 3 & 1.0 & 1 & 2 & 2 & 1.0 & 5 & 1966 & 1.3 & 0 & & \\
\hline 13 & 61 & 57.7 & 77.4 & 39.1 & 1 & 1 & 3 & 1.0 & 1 & 2 & 3 & 1.0 & 6 & 1800 & 0.9 & 50 & & 1 \\
\hline 13 & 62 & 0.0 & 49.7 & 8.4 & 13 & 1 & & 0.0 & & & & 0.0 & & & 0.0 & 484 & 1 & \\
\hline 13 & 63 & 0.0 & 45.8 & 5.8 & 13 & 1 & & 0.0 & & & & 0.0 & & & 0.0 & 310 & 1 & \\
\hline 13 & $63 \mathrm{~A}$ & 149.8 & 73.0 & 27.0 & 1 & 1 & 6 & 1.5 & 1 & 2 & 2 & 2.0 & 6 & 1980 & 1.4 & 874 & 1 & \\
\hline 13 & 63B & 96.0 & 52.1 & 4.7 & 1 & 1 & 3 & 1.0 & 1 & 2 & 2 & 1.5 & 7 & 1976 & 1.3 & 300 & 1 & \\
\hline 13 & 64 & 29.6 & 0.0 & 0.0 & 5 & 1 & 1 & 0.0 & & 3 & & 0.0 & & 1950 & 2.1 & & & \\
\hline 13 & 64 & 49.0 & 38.3 & 1.6 & 1 & 1 & 3 & 1.0 & 1 & 2 & 2 & 1.0 & 6 & 1948 & 0.9 & 324 & & \\
\hline 13 & 65 & 0.0 & 55.6 & 74.8 & 13 & 1 & & 0.0 & & & & 0.0 & & & 0.0 & 1277 & 1 & \\
\hline 13 & $65 \mathrm{~A}$ & 0.0 & 44.2 & 4.7 & 13 & 1 & & 0.0 & & & & 0.0 & & & 0.0 & 303 & 1 & \\
\hline 13 & 66 & 0.0 & 130.0 & 156.0 & 13 & 1 & & 0.0 & & & & 0.0 & & & 0.0 & 1850 & & 1 \\
\hline 13 & 67 & 0.0 & 48.1 & 7.3 & 13 & 1 & & 0.0 & & & & 0.0 & & & 0.0 & 500 & & \\
\hline 13 & 68 & 31.5 & 81.2 & 45.1 & 1 & 1 & 2 & 1.0 & 1 & 2 & 2 & 0.0 & 6 & 1900 & 1.1 & 530 & 1 & \\
\hline 13 & 69 & 57.8 & 53.3 & 5.4 & 1 & 1 & 3 & 1.0 & 1 & 2 & 3 & 1.0 & 5 & 1939 & 1.5 & 495 & & \\
\hline 13 & $70 \mathrm{~A}$ & 94.6 & 69.6 & 20.4 & 1 & 1 & 3 & 1.5 & 1 & 2 & 3 & 2.0 & 6 & 1932 & 1.0 & 500 & & \\
\hline 13 & $70 \mathrm{~B}$ & 129.1 & 52.6 & 5.0 & 1 & 1 & 4 & 2.0 & 1 & 2 & 3 & 2.5 & 8 & 1981 & 1.2 & 0 & & \\
\hline 13 & 75 & 0.0 & 1.5 & 1.0 & 15 & 1 & & 0.0 & & & & 0.0 & & & 0.0 & & & \\
\hline 13 & 76 & 0.0 & 15.0 & 10.0 & 15 & 1 & & 0.0 & & & & 0.0 & & & 0.0 & & & \\
\hline 14 & 1 & 0.0 & 46.1 & 10.0 & 13 & 4 & & 0.0 & & & & 0.0 & & & 0.0 & 410 & & 1 \\
\hline 14 & 2 & 85.0 & 54.7 & 11.7 & 1 & 4 & 4 & 1.5 & 1 & 2 & 3 & 2.0 & 7 & 1880 & 0.9 & 1067 & & 1 \\
\hline 14 & $2 \mathrm{~A}$ & 454.5 & 74.4 & 10.0 & 6 & 4 & 3 & 0.0 & & 2 & & 0.0 & & 1989 & 8.4 & & & 1 \\
\hline 14 & 2B & 0.0 & 39.4 & 5.5 & 13 & 1 & & 0.0 & & & & 0.0 & & & 0.0 & & & 1 \\
\hline 14 & $2 C$ & 0.0 & 45.0 & 5.3 & 15 & 4 & & 0.0 & & & & 0.0 & & & 0.0 & 1 & & 1 \\
\hline 14 & 3 & 78.0 & 44.1 & 4.7 & 1 & 1 & 3 & 1.0 & 1 & 2 & 2 & 2.0 & 7 & 1963 & 1.3 & 481 & & 1 \\
\hline 14 & $3 A$ & 0.0 & 50.5 & 2.0 & 14 & 4 & & 0.0 & & & & 0.0 & & & 0.0 & 700 & & 1 \\
\hline 14 & 4 & 44.9 & 37.6 & 1.3 & 1 & 1 & 2 & 1.5 & 1 & 4 & 3 & 1.0 & 6 & 1930 & 0.8 & 692 & & 1 \\
\hline 14 & 5 & 161.1 & 63.8 & 14.1 & 1 & 1 & 5 & 1.5 & 1 & 2 & 5 & 2.5 & 13 & 1739 & 1.8 & 1481 & & 1 \\
\hline 14 & 6 & 39.5 & 55.4 & 6.9 & 9 & 1 & & 0.0 & & & & 0.0 & & & 0.0 & 948 & & 1 \\
\hline 14 & 7 & 60.7 & 44.6 & 3.0 & 1 & 1 & 3 & 1.0 & 1 & 2 & 3 & 1.0 & 5 & 1964 & 1.2 & 425 & & 1 \\
\hline 14 & 8 & 105.7 & 55.6 & 7.0 & 1 & 1 & 4 & 1.5 & 1 & 2 & 3 & 2.0 & 7 & 1979 & 1.1 & 960 & & 1 \\
\hline 14 & 9 & 63.9 & 37.3 & 1.3 & 1 & 1 & 2 & 1.0 & 1 & 2 & 2 & 1.0 & 4 & 1986 & 1.2 & 200 & & 1 \\
\hline 14 & 10 & 69.8 & 38.6 & 1.6 & 1 & 1 & 3 & 1.5 & 1 & 2 & 3 & 1.5 & 7 & 1965 & 0.9 & 260 & & 1 \\
\hline 14 & 11 & 110.6 & 36.9 & 1.1 & 1 & 1 & 4 & 2.0 & 1 & 2 & 3 & 2.0 & 6 & 1965 & 1.3 & 200 & & 1 \\
\hline 14 & 13 & 0.0 & 63.9 & 24.0 & 13 & 1 & & 0.0 & & & & 0.0 & & & 0.0 & 1176 & 1 & 1 \\
\hline 14 & 14 & 73.6 & 66.6 & 15.5 & 1 & 1 & 4 & 1.5 & 1 & 1 & 5 & 1.5 & 10 & 1785 & 1.4 & 1065 & & 1 \\
\hline
\end{tabular}




\begin{tabular}{|c|c|c|c|c|c|c|c|c|c|c|c|c|c|c|c|c|c|c|}
\hline Map & Lot & $\begin{array}{l}\text { Bldg. } \\
\text { Value }\end{array}$ & $\begin{array}{l}\text { Land } \\
\text { Value }\end{array}$ & Acres & $\begin{array}{l}\text { Land } \\
\text { Use }\end{array}$ & Zoning & $\begin{array}{l}\text { Bldg. } \\
\text { Grade }\end{array}$ & $\begin{array}{l}\text { "of } \\
\text { Stories }\end{array}$ & $\begin{array}{l}\text { Occu- } \\
\text { pancy }\end{array}$ & $\begin{array}{l}\text { Heat } \\
\text { Type }\end{array}$ & $\begin{array}{l}\text { of } \\
\text { Beds }\end{array}$ & $\begin{array}{l}\text { of } \\
\text { Baths }\end{array}$ & $\begin{array}{l}\text { Total } \\
\text { Rooms }\end{array}$ & $\begin{array}{l}\text { Year } \\
\text { Built }\end{array}$ & $\begin{array}{l}\text { 1st } \\
\text { Floor }\end{array}$ & Frontage & $\begin{array}{l}\text { Wet- } \\
\text { lands }\end{array}$ & $\begin{array}{l}\text { Water } \\
\text { shed }\end{array}$ \\
\hline 14 & 15 & 0.0 & 51.6 & 12.5 & 13 & 1 & & 0.0 & & & & 0.0 & & & 0.0 & 966 & 1 & 1 \\
\hline 14 & 16 & 49.6 & 76.2 & 34.0 & 1 & 1 & 3 & 1.5 & 1 & 2 & 3 & 1.0 & 7 & 1929 & 0.8 & 750 & 1 & 1 \\
\hline 14 & 17 & 68.6 & 46.8 & 6.4 & 1 & 3 & 3 & 1.0 & 1 & 2 & 3 & 1.0 & 5 & 1986 & 1.0 & 1034 & & 1 \\
\hline 14 & $17 \mathrm{~A}$ & 72.9 & 52.0 & 4.6 & 1 & 1 & 3 & 1.0 & 1 & 2 & 3 & 1.0 & 6 & 1986 & 1.2 & 300 & & 1 \\
\hline 14 & 18 & 54.7 & 35.9 & 2.5 & 1 & 3 & 3 & 1.0 & 1 & 3 & 3 & 1.0 & 7 & 1700 & 0.9 & 312 & & 1 \\
\hline 14 & 19 & 0.0 & 71.2 & 21.6 & 72 & 3 & & 0.0 & & & & 0.0 & & & 0.0 & 753 & & 1 \\
\hline 14 & $19 A$ & 505.2 & 69.9 & 7.1 & 72 & 3 & 2 & 0.0 & 1 & 2 & & 0.0 & & 1973 & 4.6 & 394 & & 1 \\
\hline 14 & $19 \mathrm{~A}$ & 0.0 & 0.0 & 0.0 & 72 & 3 & 3 & 1.0 & 1 & 3 & 2 & 1.0 & 6 & 1987 & 0.8 & & & 1 \\
\hline 14 & $19 A 1$ & 0.0 & 57.1 & 5.3 & 72 & 3 & & 0.0 & & & & 0.0 & & & 0.0 & & & 1 \\
\hline 14 & 19B & 198.0 & 68.7 & 6.4 & 6 & 3 & 3 & 0.0 & & 2 & & 0.0 & & 1976 & 5.1 & 1588 & & 1 \\
\hline 14 & 20 & 68.8 & 35.3 & 0.9 & 1 & 1 & 3 & 1.0 & 1 & 2 & 2 & 1.0 & 6 & 1958 & 1.2 & 200 & & 1 \\
\hline 14 & 21 & 83.5 & 57.5 & 8.3 & 1 & 1 & 3 & 1.0 & 1 & 2 & 3 & 2.5 & 6 & 1989 & 1.3 & 614 & 1 & 1 \\
\hline 14 & $21 \mathrm{~A}$ & 100.4 & 52.2 & 4.8 & 1 & 1 & 3 & 2.0 & 1 & 2 & 3 & 2.5 & 6 & 1986 & 0.9 & 706 & 1 & 1 \\
\hline 14 & $21 B$ & 90.2 & 52.0 & 4.6 & 1 & 1 & 3 & 1.0 & 1 & 4 & 3 & 2.0 & 5 & 1988 & 1.5 & 314 & 1 & 1 \\
\hline 14 & $21 \mathrm{C}$ & 91.6 & 52.2 & 4.7 & 1 & 1 & 3 & 1.5 & 1 & 2 & 3 & 2.0 & 7 & 1986 & 1.0 & 368 & 1 & 1 \\
\hline 14 & 21D & 95.1 & 52.1 & 4.6 & 1 & 1 & 3 & 1.0 & 1 & 2 & 3 & 2.0 & 6 & 1986 & 1.5 & 362 & 1 & 1 \\
\hline 14 & 22 & 0.0 & 19.1 & 17.9 & 13 & 1 & & 0.0 & & & & 0.0 & & & 0.0 & 0 & 1 & 1 \\
\hline 14 & 23 & 0.0 & 78.4 & 18.0 & 13 & 1 & & 0.0 & & & & 0.0 & & & 0.0 & 400 & 1 & 1 \\
\hline 14 & $23 \mathrm{~A}$ & 0.0 & 62.2 & 21.0 & 13 & 1 & & 0.0 & & & & 0.0 & & & 0.0 & & & 1 \\
\hline 14 & 24 & 65.7 & 35.3 & 0.9 & 1 & 1 & 3 & 1.0 & 1 & 2 & 2 & 1.0 & 5 & 1966 & 1.1 & 200 & & 1 \\
\hline 14 & $24 \mathrm{~A}$ & 87.6 & 53.0 & 5.3 & 1 & 1 & 3 & 1.0 & 1 & 2 & 3 & 1.5 & 6 & 1977 & 1.1 & 302 & & 1 \\
\hline 14 & 25 & 78.5 & 36.6 & 1.0 & 1 & 1 & 3 & 1.0 & 1 & 2 & 2 & 1.5 & 7 & 1919 & 1.1 & 170 & & 1 \\
\hline 14 & $26 \mathrm{~A}$ & 67.3 & 52.1 & 4.7 & 1 & 1 & 3 & 1.0 & 1 & 2 & 2 & 1.0 & 5 & 1980 & 1.0 & 260 & & 1 \\
\hline 14 & 27 & 66.7 & 40.8 & 2.2 & 1 & 1 & 3 & 1.0 & 1 & 2 & 3 & 1.0 & 6 & 1947 & 0.7 & 190 & & 1 \\
\hline 14 & 28 & 72.6 & 41.1 & 2.3 & 1 & 1 & 3 & 1.5 & 1 & 2 & 3 & 2.0 & 6 & 1964 & 0.9 & 200 & & 1 \\
\hline 14 & 29 & 45.1 & 40.4 & 2.1 & 1 & 1 & 2 & 1.0 & 1 & 3 & 1 & 1.0 & 4 & 1953 & 1.0 & 180 & & 1 \\
\hline 14 & 31 & 66.0 & 47.4 & 3.5 & 1 & 1 & 3 & 1.0 & 1 & 2 & 3 & 1.0 & 8 & 1900 & 1.5 & 180 & & 1 \\
\hline 14 & 32 & 51.2 & 40.6 & 2.1 & 1 & 1 & 3 & 1.5 & 1 & 2 & 2 & 1.5 & 4 & 1952 & 0.8 & 180 & & 1 \\
\hline 14 & 33 & 109.0 & 53.1 & 5.3 & 1 & 1 & 3 & 2.0 & 1 & 2 & 3 & 1.5 & 7 & 1954 & 1.4 & 290 & & 1 \\
\hline 14 & 34 & 0.0 & 43.1 & 4.5 & 13 & 1 & & 0.0 & & & & 0.0 & & & 0.0 & 765 & & 1 \\
\hline 14 & 35 & 63.5 & 39.3 & 1.8 & 1 & 1 & 3 & 1.0 & 1 & 2 & 2 & 1.0 & 6 & 1957 & 1.0 & 650 & & 1 \\
\hline 14 & $35 \mathrm{~A}$ & 61.2 & 52.1 & 4.7 & 1 & 1 & 4 & 1.5 & 1 & 2 & 2 & 1.0 & 5 & 1824 & 0.9 & 1588 & & 1 \\
\hline 14 & 36 & 77.1 & 31.3 & 0.7 & 1 & 1 & 3 & 1.0 & 1 & 2 & 3 & 1.5 & 6 & 1957 & 1.3 & 165 & & 1 \\
\hline 14 & 37 & 63.8 & 30.3 & 0.6 & 1 & 1 & 3 & 1.0 & 1 & 2 & 3 & 1.0 & 6 & 1954 & 1.2 & 143 & & 1 \\
\hline 14 & 38 & 63.7 & 37.1 & 1.2 & 1 & 1 & 3 & 1.0 & 1 & 2 & 3 & 1.0 & 5 & 1950 & 1.3 & 300 & & 1 \\
\hline 14 & 39 & 71.9 & 29.4 & 0.5 & 1 & 1 & 3 & 1.0 & 1 & 2 & 2 & 1.5 & 6 & 1976 & 1.0 & 850 & & 1 \\
\hline 14 & 40 & 73.0 & 47.3 & 3.5 & 1 & 1 & 3 & 1.5 & 1 & 3 & 3 & 1.0 & 5 & 1931 & 1.1 & 1100 & & 1 \\
\hline 14 & 41 & 0.0 & 60.3 & 18.2 & 80 & 1 & & 0.0 & & & & 0.0 & & & 0.0 & 1262 & 1 & 1 \\
\hline 14 & $41 A$ & 0.0 & 80.9 & 60.0 & 13 & 1 & & 0.0 & & & & 0.0 & & & 0.0 & 0 & & 1 \\
\hline 14 & 42 & 0.0 & 44.3 & 4.8 & 13 & 1 & & 0.0 & & & & 0.0 & & & 0.0 & 688 & & 1 \\
\hline
\end{tabular}




\begin{tabular}{|c|c|c|c|c|c|c|c|c|c|c|c|c|c|c|c|c|c|c|}
\hline Map & Lot & $\begin{array}{l}\text { Bldg. } \\
\text { Value }\end{array}$ & $\begin{array}{l}\text { Land } \\
\text { Value }\end{array}$ & Acres & $\begin{array}{l}\text { Land } \\
\text { Use }\end{array}$ & Zoning & $\begin{array}{l}\text { Bldg. } \\
\text { Grade }\end{array}$ & $\begin{array}{l}\text { \# of } \\
\text { Stories }\end{array}$ & $\begin{array}{l}\text { Occu- } \\
\text { pancy }\end{array}$ & $\begin{array}{l}\text { Heat } \\
\text { Type }\end{array}$ & $\begin{array}{l}\text { \# of } \\
\text { Beds }\end{array}$ & $\begin{array}{l}\text { \# of } \\
\text { Baths }\end{array}$ & $\begin{array}{l}\text { Total } \\
\text { Rooms }\end{array}$ & $\begin{array}{l}\text { Year } \\
\text { Built }\end{array}$ & $\begin{array}{l}\text { 1st } \\
\text { Floor }\end{array}$ & Frontage & $\begin{array}{l}\text { Wet- } \\
\text { lands }\end{array}$ & $\begin{array}{l}\text { Water- } \\
\text { shed }\end{array}$ \\
\hline 14 & $42 \mathrm{~A}$ & 0.0 & 62.1 & 21.0 & 13 & 1 & & 0.0 & & & & 0.0 & & & 0.0 & 790 & 1 & 1 \\
\hline 14 & $42 \mathrm{Al}$ & 32.9 & 52.6 & 5.0 & 1 & 1 & 2 & 1.0 & 1 & 1 & 1 & 1.0 & 3 & 1978 & 0.4 & 300 & & 1 \\
\hline 14 & $42 B$ & 98.2 & 52.6 & 5.0 & 1 & 1 & 3 & 1.0 & 1 & 2 & 3 & 1.0 & 7 & 1900 & 2.1 & 241 & 1 & 1 \\
\hline 14 & 43 & 72.0 & 60.1 & 10.0 & 1 & 1 & 3 & 1.0 & 1 & 2 & 2 & 1.0 & 6 & 1948 & 1.4 & 300 & & 1 \\
\hline 14 & 45 & 74.8 & 67.0 & 17.0 & 1 & 1 & 3 & 2.0 & 1 & 2 & 4 & 2.0 & 8 & 1936 & 0.8 & 1250 & & 1 \\
\hline 14 & 46 & 42.4 & 29.4 & 0.5 & 1 & 1 & 3 & 1.0 & 1 & 2 & 1 & 1.0 & 3 & 1800 & 0.7 & 83 & & 1 \\
\hline 14 & 47 & 0.0 & 70.7 & 36.0 & 13 & 1 & & 0.0 & & & & 0.0 & & & 0.0 & 1030 & & 1 \\
\hline 14 & 48 & 235.7 & 38.9 & 1.8 & 4 & 1 & 3 & 0.0 & & 2 & & 0.0 & & 1875 & 4.7 & 472 & & 1 \\
\hline 14 & 49 & 103.6 & 83.5 & 50.5 & 1 & 1 & 4 & 1.5 & 1 & 2 & 4 & 2.5 & 10 & 1740 & 1.6 & 700 & & 1 \\
\hline 14 & 50 & 0.0 & 80.7 & 113.0 & 9 & 1 & & 0.0 & & & & 0.0 & & & 0.0 & 0 & & 1 \\
\hline 14 & 51 & 49.7 & 57.9 & 8.5 & 1 & 1 & 3 & 1.0 & 1 & 2 & 2 & 1.0 & 4 & 1953 & 0.8 & 386 & & 1 \\
\hline 14 & 52 & 0.0 & 7.9 & 1.6 & 13 & 1 & & 0.0 & & & & 0.0 & & & 0.0 & 100 & & 1 \\
\hline 14 & 53 & 99.8 & 69.5 & 20.0 & 1 & 1 & 6 & 1.0 & 1 & 2 & 3 & 1.0 & 7 & 1761 & 1.2 & 600 & & 1 \\
\hline 14 & 54 & 48.9 & 83.9 & 45.8 & 1 & 1 & 3 & 1.5 & 1 & 2 & 2 & 1.0 & 5 & 1800 & 0.7 & 310 & & 1 \\
\hline 14 & $54 \mathrm{~A}$ & 74.7 & 52.9 & 5.2 & 1 & 1 & 3 & 1.0 & 1 & 2 & 3 & 2.0 & 6 & 1976 & 1.2 & 195 & & 1 \\
\hline 14 & 55 & 0.0 & 84.6 & 61.3 & 13 & 1 & & 0.0 & & & & 0.0 & & & 0.0 & 850 & & 1 \\
\hline 14 & $55 \mathrm{~A}$ & 55.7 & 52.6 & 5.0 & 1 & 1 & 3 & 2.0 & 1 & 2 & 2 & 1.0 & 4 & 1900 & 0.6 & 300 & & 1 \\
\hline 14 & $55 \mathrm{~B}$ & 106.7 & 52.6 & 5.0 & 1 & 1 & 4 & 1.5 & 1 & 2 & 3 & 2.0 & 7 & 1986 & 1.0 & 572 & & 1 \\
\hline 14 & $55 \mathrm{C}$ & 104.5 & 52.6 & 5.0 & 1 & 1 & 5 & 2.0 & 1 & 2 & 3 & 1.5 & 7 & 1986 & 0.8 & & & 1 \\
\hline 14 & 56 & 60.8 & 53.4 & 5.5 & 1 & 1 & 3 & 1.0 & 1 & 2 & 2 & 1.0 & 5 & 1958 & 0.9 & 30 & & 1 \\
\hline 14 & 57 & 39.3 & 37.9 & 1.4 & 1 & 1 & 3 & 1.0 & i & 2 & 2 & 1.0 & 5 & 1932 & 0.7 & 257 & & 1 \\
\hline 14 & 58 & 0.0 & 45.3 & 5.5 & 13 & 1 & & 0.0 & & & & 0.0 & & & 0.0 & 665 & 1 & 1 \\
\hline 14 & $58 \mathrm{~A}$ & 90.8 & 53.8 & 5.8 & 1 & 1 & 3 & 1.5 & 1 & 2 & 3 & 2.0 & 8 & 1820 & 1.0 & 596 & & 1 \\
\hline 14 & 59 & 0.0 & 19.7 & 15.2 & 15 & 1 & & 0.0 & & & & 0.0 & & & 0.0 & 300 & & 1 \\
\hline 14 & $59 \mathrm{~B}$ & 0.0 & 51.1 & 10.4 & 15 & 1 & & 0.0 & & & & 0.0 & & & 0.0 & 400 & 1 & 1 \\
\hline 14 & 60 & 0.0 & 29.0 & 35.0 & 15 & 1 & & 0.0 & & & & 0.0 & & & 0.0 & & & 1 \\
\hline 14 & 61 & 60.7 & 55.6 & 7.0 & 1 & 1 & 3 & 1.0 & 1 & 2 & 3 & 1.0 & 6 & 1950 & 0.8 & 260 & & 1 \\
\hline 14 & $61 \mathrm{~A}$ & 63.0 & 52.6 & 5.0 & 1 & 1 & 3 & 1.0 & 1 & 2 & 3 & 1.0 & 5 & 1975 & 1.1 & & & 1 \\
\hline 14 & 62 & 31.9 & 37.6 & 1.4 & $i$ & 1 & 2 & 2.0 & 1 & 3 & 2 & 1.0 & 5 & 1945 & 0.5 & 60 & & 1 \\
\hline 14 & 63 & 7.8 & 36.6 & 1.0 & $i$ & 1 & 1 & 1.0 & 1 & 1 & 0 & 0.0 & 1 & 1850 & 0.4 & 260 & & 1 \\
\hline 14 & 64 & 107.0 & 61.2 & 11.0 & 1 & 1 & 3 & 1.0 & 1 & 4 & 2 & 2.0 & 8 & 1988 & 2.0 & 0 & & 1 \\
\hline 14 & 65 & 91.8 & 74.9 & 29.3 & 1 & 1 & 3 & 1.0 & 1 & 2 & 2 & 1.0 & 6 & 1972 & 1.7 & 486 & & 1 \\
\hline 14 & 66 & 95.0 & 69.9 & 20.7 & 1 & $i$ & 3 & 1.0 & 1 & 2 & 3 & 1.0 & 8 & 1946 & 1.4 & 560 & & $i$ \\
\hline 14 & 67 & 0.0 & 52.1 & 10.0 & 13 & 1 & & 0.0 & & & & 0.0 & & & 0.0 & 900 & & 1 \\
\hline 14 & 68 & 48.4 & 46.2 & 3.4 & 1 & 1 & 3 & 1.5 & 1 & 2 & 3 & 1.0 & 6 & 1850 & 0.9 & 335 & & 1 \\
\hline 14 & 69 & 7.1 & 69.5 & 20.0 & 1 & 1 & 1 & 1.0 & 1 & 1 & 0 & 0.0 & 3 & 1930 & 0.4 & 1500 & & 1 \\
\hline 14 & 70 & 198.4 & 83.7 & 45.3 & i & $i$ & 5 & 2.0 & 2 & 2 & 5 & 2.0 & 12 & 1760 & 2.0 & 666 & 1 & 1 \\
\hline 14 & 70 & 0.0 & 0.0 & 0.0 & $i$ & 1 & 3 & 1.0 & 1 & 2 & 0 & 1.0 & 2 & 1760 & 0.4 & & & 1 \\
\hline 14 & $70 \mathrm{~A}$ & 62.1 & 52.6 & 5.0 & $i$ & $i$ & 3 & 1.0 & 1 & 2 & 2 & 1.0 & 4 & 1975 & 1.0 & 300 & 1 & 1 \\
\hline 14 & 71 & 43.4 & 37.9 & 1.5 & 1 & 1 & 3 & 1.0 & $i$ & 2 & 1 & 1.0 & 4 & 1880 & 0.5 & 350 & & 1 \\
\hline
\end{tabular}




\begin{tabular}{|c|c|c|c|c|c|c|c|c|c|c|c|c|c|c|c|c|c|c|}
\hline Map & Lot & $\begin{array}{l}\text { Bldg. } \\
\text { Value }\end{array}$ & $\begin{array}{l}\text { Land } \\
\text { Value }\end{array}$ & Acres & $\begin{array}{l}\text { Land } \\
\text { Use }\end{array}$ & Zoning & $\begin{array}{l}\text { Bldg. } \\
\text { Grade }\end{array}$ & $\begin{array}{l}\text { "of } \\
\text { Stories }\end{array}$ & $\begin{array}{l}\text { Occu- } \\
\text { pancy }\end{array}$ & $\begin{array}{l}\text { Heat } \\
\text { Type }\end{array}$ & $\begin{array}{l}\text { \# of } \\
\text { Beds }\end{array}$ & $\begin{array}{l}\text { \# of } \\
\text { Baths }\end{array}$ & $\begin{array}{l}\text { Total } \\
\text { Rooms }\end{array}$ & $\begin{array}{l}\text { Year } \\
\text { Built }\end{array}$ & $\begin{array}{l}\text { 1st } \\
\text { Floor }\end{array}$ & Frontage & $\begin{array}{l}\text { Wet- } \\
\text { lands }\end{array}$ & $\begin{array}{l}\text { Water- } \\
\text { shed }\end{array}$ \\
\hline 14 & 72 & 64.4 & 91.0 & 34.8 & 1 & 1 & 3 & 1.0 & 1 & 2 & 3 & 1.0 & 5 & 1960 & 1.2 & 410 & 1 & 1 \\
\hline 14 & $72 \mathrm{~A}$ & 70.4 & 57.1 & 7.8 & 1 & 1 & 3 & 2.0 & 1 & 3 & 2 & 1.0 & 5 & 1984 & 0.8 & 405 & 1 & 1 \\
\hline 14 & $72 B$ & 95.6 & 59.5 & 9.6 & 1 & 1 & 4 & 1.5 & 1 & 2 & 3 & 2.0 & 6 & 1986 & 1.0 & 242 & & 1 \\
\hline 14 & 73 & 6.1 & 21.4 & 2.5 & 1 & 1 & 1 & 1.0 & 1 & 1 & 1 & 0.0 & 1 & 1940 & 0.3 & 260 & & 1 \\
\hline 14 & 74 & 110.3 & 52.1 & 4.7 & 1 & $i$ & 5 & 1.5 & 1 & 2 & 4 & 1.0 & 11 & 1840 & 1.5 & 327 & 1 & 1 \\
\hline 14 & $74 A$ & 143.6 & 66.4 & 15.2 & 1 & 1 & 4 & 1.5 & 1 & 2 & 5 & 2.0 & 11 & 1980 & 1.5 & 500 & 1 & 1 \\
\hline 14 & 75 & 83.4 & 42.3 & 2.4 & 1 & 1 & 3 & 2.0 & 1 & 2 & 3 & 1.0 & 6 & 1929 & 0.9 & 280 & & 1 \\
\hline 14 & 76 & 100.0 & 63.5 & 14.0 & 1 & 1 & 3 & 1.5 & $i$ & 2 & 3 & 2.0 & 8 & 1910 & 1.2 & 810 & & 1 \\
\hline 14 & 76 & 0.0 & 0.0 & 0.0 & 1 & 1 & 3 & 1.0 & 1 & 2 & 2 & 1.0 & 1 & 1970 & 0.6 & & & 1 \\
\hline 14 & 77 & 75.7 & 48.2 & 4.0 & 1 & 1 & 3 & 1.5 & 1 & 2 & 3 & 2.0 & 8 & 1923 & 1.3 & 925 & & 1 \\
\hline 14 & 78 & 142.3 & 52.6 & 5.0 & 1 & 1 & 4 & 1.5 & 1 & 4 & 2 & 2.5 & 6 & 1975 & 1.4 & 913 & & 1 \\
\hline 14 & 79 & 124.1 & 57.4 & 8.2 & 1 & 1 & 4 & 2.0 & 1 & 4 & 4 & 2.5 & 8 & 1979 & 1.1 & 350 & & 1 \\
\hline 14 & 80 & 70.2 & 45.7 & 3.2 & 1 & 1 & 3 & 1.0 & 1 & 2 & 2 & 1.0 & 7 & 1954 & 1.4 & 380 & & 1 \\
\hline 14 & 81 & 75.4 & 43.0 & 2.6 & $i$ & $i$ & 3 & 1.0 & $i$ & 2 & 3 & 1.5 & 6 & 1979 & 1.1 & 290 & & 1 \\
\hline 14 & 82 & 80.3 & 52.1 & 4.6 & 1 & 1 & 3 & 1.5 & 1 & 2 & 3 & 2.5 & 6 & 1985 & 0.9 & 328 & 1 & 1 \\
\hline 14 & $82 \mathrm{~A}$ & 74.9 & 29.4 & 0.5 & 78 & 1 & 3 & 0.0 & & 2 & & 0.0 & & 1965 & 0.6 & 177 & & 1 \\
\hline 14 & $82 B$ & 117.8 & 52.9 & 5.2 & 1 & $i$ & 4 & 1.5 & 1 & 4 & 2 & 1.5 & 7 & 1978 & 1.2 & 306 & 1 & 1 \\
\hline 14 & 83 & 143.9 & 96.7 & 70.0 & 1 & 1 & 4 & 1.0 & 1 & 2 & 2 & 1.5 & 5 & 1982 & 1.8 & 2750 & 1 & 1 \\
\hline 14 & 84 & 6.4 & 87.7 & 75.0 & 1 & 1 & 3 & 1.0 & 1 & 2 & 2 & 1.0 & 5 & 1952 & 0.8 & 450 & 1 & 1 \\
\hline 14 & 85 & 78.7 & 37.3 & 1.2 & 1 & 1 & 3 & 1.0 & 1 & 2 & 2 & 1.0 & 5 & 1974 & 1.0 & 186 & & 1 \\
\hline 14 & 86 & 0.0 & 23.8 & 0.7 & 13 & 1 & & 0.0 & & & & 0.0 & & & 0.0 & 250 & & 1 \\
\hline 14 & 87 & 61.3 & 41.8 & 4.0 & 1 & 1 & 3 & 1.5 & 1 & 2 & 2 & 2.0 & 6 & 1930 & 1.0 & 325 & & 1 \\
\hline 14 & 88 & 56.5 & 59.9 & 17.7 & $i$ & $i$ & 3 & 1.5 & 1 & 1 & 4 & 1.0 & 8 & 1935 & 0.7 & 500 & & 1 \\
\hline 14 & 89 & 75.2 & 45.0 & 5.3 & 1 & 1 & 3 & 2.0 & 1 & 2 & 4 & 2.0 & 7 & 1950 & 0.9 & 859 & & 1 \\
\hline 14 & 90 & 49.6 & 60.5 & 23.0 & 1 & 1 & 3 & 1.0 & 1 & 2 & 1 & 1.0 & 4 & 1938 & 0.7 & 349 & & 1 \\
\hline 14 & $90 \mathrm{~A}$ & 71.9 & 34.0 & 2.0 & 1 & 1 & 3 & 1.0 & 1 & 2 & 5 & 2.0 & 7 & 1950 & 1.5 & 376 & & 1 \\
\hline 14 & 91 & 57.3 & 27.4 & 0.6 & 1 & 1 & 3 & 1.0 & 1 & 2 & 3 & 1.0 & 7 & 1940 & 0.9 & 100 & & 1 \\
\hline 14 & 92 & 50.1 & 37.7 & 3.1 & $i$ & 1 & 3 & 1.0 & 1 & 3 & 2 & 1.0 & 4 & 1935 & 0.8 & 258 & & 1 \\
\hline 14 & 95 & 0.0 & 58.3 & 15.0 & 13 & 1 & & 0.0 & & & & 0.0 & & & 0.0 & 1265 & & $i$ \\
\hline 14 & $95 \mathrm{~A}$ & 0.0 & 50.4 & 8.9 & 13 & 1 & & 0.0 & & & & 0.0 & & & 0.0 & 304 & & 1 \\
\hline 14 & $95 \mathrm{~B}$ & 0.0 & 53.4 & 11.1 & 13 & 1 & & 0.0 & & & & 0.0 & & & 0.0 & 463 & & 1 \\
\hline 14 & 96 & 12.2 & 46.2 & 6.1 & 1 & 3 & 1 & 1.0 & & 1 & $\infty$ & 0.0 & 1 & 1940 & 0.7 & 1875 & & 1 \\
\hline 14 & $96 A$ & 0.0 & 52.9 & 1.0 & 14 & 3 & & 0.0 & & & & 0.0 & & & 0.0 & & & 1 \\
\hline 14 & 97 & 138.5 & 66.1 & 5.7 & 4 & 1 & 3 & 0.0 & & 2 & & 0.0 & & 1963 & 1.4 & 516 & & 1 \\
\hline 14 & 98 & 222.1 & 80.9 & 17.0 & 7 & 1 & 3 & 0.0 & 2 & 3 & & 0.0 & & 1979 & 4.9 & 500 & & 1 \\
\hline 14 & 100 & 51.8 & 44.0 & 23.0 & 2 & i & 3 & 2.0 & 2 & 2 & 5 & 2.0 & 10 & 1954 & 1.3 & 228 & & 1 \\
\hline 14 & 100 & 79.5 & 60.2 & 4.6 & 3 & 1 & 2 & 1.0 & 8 & 2 & & 0.0 & & 1949 & 1.7 & & & 1 \\
\hline 14 & 101 & 44.1 & 0.0 & 0.0 & 1 & 1 & 3 & 1.0 & 1 & 2 & 2 & 1.0 & 5 & 1938 & 1.1 & & & 1 \\
\hline 14 & 101 & 24.9 & 70.3 & 7.5 & 5 & 1 & 3 & 0.0 & & 2 & & 0.0 & & 1945 & 1.0 & 578 & & 1 \\
\hline 14 & 102 & 0.0 & 45.8 & 11.0 & 13 & 1 & & 0.0 & & & & 0.0 & & & 0.0 & 700 & 1 & 1 \\
\hline
\end{tabular}




\begin{tabular}{|c|c|c|c|c|c|c|c|c|c|c|c|c|c|c|c|c|c|c|}
\hline Map & Lat & $\begin{array}{l}\text { Bldg. } \\
\text { Value }\end{array}$ & $\begin{array}{l}\text { Land } \\
\text { Value }\end{array}$ & Acres & $\begin{array}{l}\text { Land } \\
\text { Use }\end{array}$ & Zoning & $\begin{array}{l}\text { Bldg. } \\
\text { Grade }\end{array}$ & $\begin{array}{l}\text { of } \\
\text { Stories }\end{array}$ & $\begin{array}{l}\text { Occu- } \\
\text { pancy }\end{array}$ & $\begin{array}{l}\text { Heat } \\
\text { Type }\end{array}$ & $\begin{array}{l}\text { of } \\
\text { Beds }\end{array}$ & $\begin{array}{l}\text { of } \\
\text { Baths }\end{array}$ & $\begin{array}{l}\text { Total } \\
\text { Rooms }\end{array}$ & $\begin{array}{l}\text { Year } \\
\text { Built }\end{array}$ & $\begin{array}{l}\text { 1st } \\
\text { Floor }\end{array}$ & Frontage & $\begin{array}{l}\text { Wet- } \\
\text { lands }\end{array}$ & $\begin{array}{l}\text { Water } \\
\text { shed }\end{array}$ \\
\hline 14 & $102 \mathrm{~A}$ & 100.0 & 45.7 & 5.7 & 1 & 1 & 4 & 1.5 & 1 & 4 & 4 & 2.0 & 7 & 1977 & 1.0 & 424 & 1 & 1 \\
\hline 14 & 103 & 2068.4 & 67.3 & 17.2 & 79 & 1 & 3 & 2.0 & & & & 0.0 & & 1952 & 52. & 575 & 1 & 1 \\
\hline 14 & 104 & 323.5 & 61.0 & 2.5 & 72 & 1 & 2 & 0.0 & & 2 & & 0.0 & & 1960 & 3.2 & 618 & & 1 \\
\hline 14 & 105 & 443.4 & 79.1 & 18.4 & 6 & 1 & 3 & 0.0 & & 2 & & 0.0 & & 1976 & 5.0 & 685 & & 1 \\
\hline 14 & $105 \mathrm{~A}$ & 78.4 & 60.4 & 10.4 & 1 & 1 & 3 & 1.0 & 1 & 4 & 4 & 2.0 & 6 & 1974 & 1.3 & 604 & & 1 \\
\hline 14 & $105 \mathrm{C}$ & 99.9 & 52.1 & 4.6 & 1 & 4 & 3 & 1.0 & 1 & 2 & 4 & 2.0 & 9 & 1972 & 1.4 & 507 & & 1 \\
\hline 14 & 105D & 91.8 & 45.8 & 6.0 & 1 & 1 & 3 & 2.0 & 1 & 4 & 3 & 2.5 & 6 & 1986 & 1.1 & 333 & & 1 \\
\hline 14 & $105 E$ & 78.3 & 52.1 & 4.6 & 1 & 1 & 3 & 1.0 & 1 & 2 & 2 & 1.0 & 5 & 1988 & 1.1 & 487 & & 1 \\
\hline 14 & 106 & 79.0 & 27.4 & 0.8 & $i$ & 4 & 3 & 2.0 & $i$ & 3 & 2 & 1.0 & 6 & 1920 & 1.0 & 310 & & 1 \\
\hline 14 & 107 & 52.0 & 32.9 & 0.3 & 6 & 4 & 2 & 0.0 & & 2 & & 0.0 & & 1900 & 1.8 & 180 & & 1 \\
\hline 14 & 108 & 68.7 & 39.5 & 1.8 & 1 & 1 & 3 & 1.5 & 1 & 3 & 2 & 2.0 & 5 & 1954 & 1.2 & 325 & & 1 \\
\hline 14 & 109 & 59.2 & 34.7 & 2.2 & 1 & 4 & 3 & 1.5 & 1 & 2 & 2 & 1.0 & 6 & 1940 & 0.7 & 625 & & 1 \\
\hline 14 & 110 & 55.2 & 39.6 & 3.5 & 1 & 4 & 3 & 1.0 & 1 & 2 & 1 & 1.0 & 4 & 1940 & 0.8 & 200 & & 1 \\
\hline 14 & 111 & 48.1 & 23.6 & 0.5 & 1 & 4 & 3 & 1.0 & 1 & 2 & 2 & 1.0 & 6 & 1920 & 1.0 & 100 & & 1 \\
\hline 14 & 112 & 49.7 & 22.1 & 0.4 & 1 & 4 & 3 & 1.0 & 1 & 2 & 2 & 1.0 & 6 & 1949 & 1.3 & 60 & & 1 \\
\hline 14 & 113 & 45.8 & 22.1 & 0.4 & 1 & 4 & 3 & 1.0 & 1 & 2 & 2 & 1.0 & 5 & 1944 & 1.0 & 90 & & 1 \\
\hline 14 & 114 & 49.7 & 23.6 & 0.5 & 1 & 4 & 3 & 1.5 & 1 & 2 & 2 & 1.0 & 5 & 1940 & 1.2 & 100 & & 1 \\
\hline 14 & 115 & 7.6 & 54.0 & 11.5 & 1 & 4 & 3 & 1.0 & 1 & 2 & 3 & 1.0 & 5 & 1968 & 0.7 & 388 & & 1 \\
\hline 14 & 116 & 62.8 & 34.0 & 1.9 & 1 & 4 & 3 & 1.0 & 1 & 2 & 3 & 2.0 & 5 & 1959 & 1.0 & 325 & & 1 \\
\hline 14 & 117 & 0.0 & 50.9 & 1.0 & 14 & 4 & & 0.0 & & & & 0.0 & & & 0.0 & 169 & & 1 \\
\hline 14 & 118 & 0.0 & 25.2 & 0.9 & 13 & 4 & & 0.0 & & & & 0.0 & & & 0.0 & 160 & & 1 \\
\hline 14 & 119 & 0.0 & 28.9 & 2.0 & 13 & 4 & & 0.0 & & & & 0.0 & & & 0.0 & 465 & & 1 \\
\hline 15 & 1 & 0.0 & 123.8 & 146.7 & 13 & 1 & & 0.0 & & & & 0.0 & & & 0.0 & 50 & 1 & 1 \\
\hline 15 & 2 & 97.7 & 77.1 & 33.0 & 1 & $i$ & 4 & 2.0 & 1 & 2 & 4 & 2.0 & 8 & 1875 & 0.9 & 600 & 1 & 1 \\
\hline 15 & 3 & 80.3 & 75.4 & 30.0 & 1 & 1 & 3 & 1.0 & 1 & 4 & 2 & 1.0 & 7 & 1966 & 1.3 & 1481 & 1 & 1 \\
\hline 15 & 4 & 0.0 & 6.2 & 0.6 & 13 & 1 & & 0.0 & & & & 0.0 & & & 0.0 & 540 & & 1 \\
\hline 15 & 5 & 120.3 & 72.3 & 30.0 & 1 & 1 & 4 & 2.0 & 1 & 4 & 2 & 2.0 & 6 & 1972 & 1.2 & 870 & 1 & 1 \\
\hline 15 & 6 & 137.5 & 72.6 & 26.2 & 1 & 1 & 4 & 2.0 & 1 & 2 & 5 & 2.0 & 9 & 1972 & 1.2 & 1000 & 1 & 1 \\
\hline 15 & $6 A$ & 85.8 & 58.1 & 10.4 & $i$ & 1 & 3 & 1.5 & 1 & 2 & 3 & 2.0 & 7 & 1973 & 0.8 & 753 & 1 & 1 \\
\hline 15 & 8 & 0.0 & 3.8 & 1.3 & 13 & $i$ & & 0.0 & & & & 0.0 & & & 0.0 & 280 & & 1 \\
\hline 15 & 9 & 127.8 & 43.9 & 2.8 & 1 & 1 & 4 & 2.0 & 1 & 3 & 4 & 2.0 & 9 & 1978 & 1.3 & 533 & & 1 \\
\hline 15 & 10 & 73.4 & 55.7 & 7.1 & 12 & 1 & 3 & 1.0 & 1 & 2 & 3 & 1.0 & 6 & 1974 & 1.0 & 1090 & 1 & 1 \\
\hline 15 & 10 & 73.4 & 0.0 & 0.0 & 1 & i & 3 & 2.0 & 1 & 2 & 3 & 1.0 & 6 & 1900 & 0.9 & & & 1 \\
\hline 15 & $10 \mathrm{~A}$ & 155.0 & 52.2 & 4.8 & 1 & 1 & 4 & 2.0 & $i$ & 2 & 3 & 2.5 & 9 & 1978 & 1.6 & 522 & & 1 \\
\hline 15 & $10 \mathrm{~B}$ & 0.0 & 15.9 & 2.7 & 10 & $i$ & & 0.0 & & & & 0.0 & & & 0.0 & 300 & 1 & 1 \\
\hline 15 & 11 & 0.0 & 276.0 & 46.0 & 10 & 1 & & 0.0 & & & & 0.0 & & & 0.0 & 1500 & 1 & 1 \\
\hline 15 & 12 & 76.9 & 67.9 & 17.6 & 1 & $i$ & 4 & 1.0 & 1 & 2 & 3 & 1.5 & 7 & 1812 & 1.2 & 207 & 1 & 1 \\
\hline 15 & 13 & 0.0 & 0.0 & 0.0 & 1 & 1 & 1 & 2.0 & 1 & 1 & 2 & 1.0 & 3 & 1952 & 0.4 & 227 & 1 & 1 \\
\hline 15 & 13 & 98.1 & 82.0 & 42.0 & 1 & 1 & 4 & 1.0 & 1 & 2 & 3 & 1.5 & 6 & 1821 & 1.1 & 227 & 1 & 1 \\
\hline 15 & 14 & 75.8 & 36.6 & 1.0 & 1 & 1 & 2 & 1.0 & 1 & 4 & 2 & 2.0 & 1 & 1964 & 1.4 & 0 & & $i$ \\
\hline
\end{tabular}




\begin{tabular}{|c|c|c|c|c|c|c|c|c|c|c|c|c|c|c|c|c|c|c|}
\hline Map & Lot & $\begin{array}{l}\text { Bldg. } \\
\text { Value }\end{array}$ & $\begin{array}{l}\text { Land } \\
\text { Value }\end{array}$ & Acres & $\begin{array}{l}\text { Land } \\
\text { Use }\end{array}$ & Zoning & $\begin{array}{l}\text { Bldg. } \\
\text { Grade }\end{array}$ & $\begin{array}{l}\text { \# of } \\
\text { Stories }\end{array}$ & $\begin{array}{l}\text { Occu- } \\
\text { pancy }\end{array}$ & $\begin{array}{l}\text { Heat } \\
\text { Type }\end{array}$ & $\begin{array}{l}\text { Iof } \\
\text { Beds }\end{array}$ & $\begin{array}{l}\text { \# of } \\
\text { Baths }\end{array}$ & $\begin{array}{l}\text { Total } \\
\text { Rooms }\end{array}$ & $\begin{array}{l}\text { Year } \\
\text { Built }\end{array}$ & $\begin{array}{l}\text { 1st } \\
\text { Floor }\end{array}$ & Frontage & $\begin{array}{l}\text { Wet- } \\
\text { lands }\end{array}$ & $\begin{array}{l}\text { Water- } \\
\text { shed }\end{array}$ \\
\hline 15 & 15 & 0.0 & 73.3 & 40.5 & 13 & 1 & & 0.0 & & & & 0.0 & & & 0.0 & 425 & 1 & 1 \\
\hline 15 & $15 A$ & 0.0 & 65.5 & 10.9 & 10 & 1 & & 0.0 & & & & 0.0 & & & 0.0 & 0 & & 1 \\
\hline 15 & $15 B$ & 0.0 & 44.1 & 4.6 & 13 & 1 & & 0.0 & & & & 0.0 & & & 0.0 & 300 & & 1 \\
\hline 15 & 16 & 36.7 & 48.8 & 4.0 & 1 & 1 & 2 & 1.0 & 1 & 1 & 3 & 1.0 & 5 & 1945 & 0.7 & 400 & & 1 \\
\hline 15 & 17 & 49.0 & 37.9 & 1.4 & 1 & 1 & 3 & 1.0 & $i$ & 2 & 3 & 1.0 & 5 & 1964 & 0.8 & 200 & & 1 \\
\hline 15 & 18 & 0.0 & 27.4 & 0.8 & 13 & 1 & & 0.0 & & & & 0.0 & & & 0.0 & 100 & & 1 \\
\hline 15 & $18 \mathrm{~A}$ & 0.0 & 54.7 & 12.0 & 15 & 1 & & 0.0 & & & & 0.0 & & & 0.0 & 0 & 1 & 1 \\
\hline 15 & 19 & 0.0 & 48.6 & 8.1 & 10 & 1 & & 0.0 & & & & 0.0 & & & 0.0 & 105 & & $i$ \\
\hline 15 & 20 & 115.4 & 78.1 & 35.0 & 2 & 1 & 5 & 1.5 & 2 & 2 & 5 & 2.0 & 1 & 1780 & 1.7 & 2400 & 1 & 1 \\
\hline 15 & $20 \mathrm{~A}$ & 0.0 & 77.5 & 12.9 & 10 & 1 & & 0.0 & & & & 0.0 & & & 0.0 & 270 & 1 & $i$ \\
\hline 15 & 21 & 0.0 & 0.0 & 0.0 & 1 & 1 & 2 & 1.0 & 1 & 2 & 2 & 1.0 & 5 & 1850 & 1.0 & & & 1 \\
\hline 15 & 21 & 57.6 & 60.2 & 10.0 & 4 & 1 & 1 & 0.0 & 1 & 2 & & 0.0 & & 1900 & 0.8 & 220 & 1 & 1 \\
\hline 15 & 21 & 54.5 & 0.0 & 0.0 & 1 & 1 & 1 & 1.0 & 1 & 3 & 1 & 1.0 & 3 & 1950 & 0.5 & & & $i$ \\
\hline 15 & $21 \mathrm{~A}$ & 0.0 & 34.4 & 0.8 & 10 & 1 & & 0.0 & & & & 0.0 & & & 0.0 & 0 & & $i$ \\
\hline 15 & 22 & 0.0 & 50.8 & 23.7 & 13 & 1 & & 0.0 & & & & 0.0 & & & 0.0 & 50 & 1 & 1 \\
\hline 15 & $22 \mathrm{~A}$ & 0.0 & 5.0 & 0.8 & 10 & 1 & & 0.0 & & & & 0.0 & & & 0.0 & 0 & & 1 \\
\hline 15 & 23 & 0.0 & 70.7 & 62.0 & 13 & 1 & & 0.0 & & & & 0.0 & & & 0.0 & 800 & 1 & 1 \\
\hline 15 & 24 & 0.0 & 47.9 & 7.2 & 13 & 1 & & 0.0 & & & & 0.0 & & & 0.0 & 580 & $i$ & 1 \\
\hline 15 & $24 \mathrm{~A}$ & 65.3 & 52.9 & 5.2 & 1 & 1 & 3 & 1.5 & 1 & 2 & 2 & 1.5 & 5 & 1972 & 0.8 & 475 & & $i$ \\
\hline 15 & 25 & 54.1 & 69.4 & 112.0 & 1 & 1 & 3 & 1.0 & 1 & 3 & 0 & 1.0 & 3 & 1900 & 1.2 & 2400 & 1 & 1 \\
\hline 15 & 26 & 85.8 & 57.1 & 8.0 & 1 & 1 & 4 & 1.0 & 1 & 2 & 4 & 2.0 & 8 & 1700 & 1.3 & 1125 & & 1 \\
\hline 15 & 27 & 171.6 & 75.4 & 30.0 & $i$ & 1 & 6 & 2.0 & 1 & 2 & 4 & 1.5 & 8 & 1981 & 1.3 & 914 & & 1 \\
\hline 15 & 28 & 63.9 & 54.6 & 6.3 & 1 & 1 & 3 & 1.0 & i & 2 & 2 & 1.0 & 6 & 1900 & 1.1 & 75 & & 1 \\
\hline 15 & 29 & 7.2 & 64.0 & 13.0 & 1 & 1 & 1 & 1.0 & 0 & 1 & 1 & 0.0 & 2 & 1930 & 0.8 & 1450 & & 1 \\
\hline 15 & 30 & 59.5 & 54.1 & 6.0 & 1 & 1 & 3 & 2.0 & 1 & 1 & 2 & 1.0 & 5 & 1987 & 0.6 & 10 & & $i$ \\
\hline 15 & 31 & 5.0 & 62.7 & 12.0 & 1 & 1 & & 0.0 & & & & 0.0 & & & 0.0 & 268 & 1 & i \\
\hline 15 & 32 & 0.0 & 3.7 & 0.2 & 13 & 1 & & 0.0 & & & & 0.0 & & & 0.0 & 400 & & 1 \\
\hline 15 & $32 \mathrm{~A}$ & 0.0 & 1.3 & 0.2 & 13 & 1 & & 0.0 & & & & 0.0 & & & 0.0 & 0 & & 1 \\
\hline 15 & $32 \mathrm{~B}$ & 0.0 & 3.7 & 0.2 & 13 & 1 & & 0.0 & & & & 0.0 & & & 0.0 & 0 & & 1 \\
\hline 15 & $32 C$ & 0.0 & 3.7 & 0.2 & 13 & 1 & & 0.0 & & & & 0.0 & & & 0.0 & 0 & & 1 \\
\hline 15 & 33 & 0.0 & 18.8 & 17.3 & 15 & 1 & & 0.0 & & & & 0.0 & & & 0.0 & 0 & & 1 \\
\hline 15 & 34 & 91.1 & 58.7 & 9.1 & 1 & 1 & 3 & 2.0 & 2 & 2 & 3 & 2.0 & 7 & 1987 & 1.0 & 325 & & 1 \\
\hline 15 & 35 & 0.0 & 38.2 & 3.3 & 13 & 1 & & 0.0 & & & & 0.0 & & & 0.0 & 127 & & $i$ \\
\hline 15 & 36 & 0.0 & 38.2 & 3.3 & 13 & 1 & & 0.0 & & & & 0.0 & & & 0.0 & 132 & & 1 \\
\hline 15 & 38 & 0.0 & 39.0 & 3.2 & 13 & $i$ & & 0.0 & & & & 0.0 & & & 0.0 & 197 & & 1 \\
\hline 15 & 39 & 143.5 & 60.5 & 10.5 & 1 & 1 & 4 & 2.0 & 1 & 2 & 4 & 2.5 & 1 & 1987 & 1.5 & 654 & & $i$ \\
\hline 15 & 41 & 58.1 & 44.6 & 3.1 & 1 & 1 & 3 & 1.0 & 1 & 2 & 3 & 1.0 & 6 & 1969 & 1.0 & 200 & & 1 \\
\hline 15 & 42 & 0.0 & 37.8 & 3.1 & 15 & 1 & & 0.0 & & & & 0.0 & & & 0.0 & 215 & & 1 \\
\hline 15 & 43 & 61.4 & 44.6 & 3.1 & 1 & 1 & 3 & 1.0 & 1 & 2 & 2 & 1.0 & 5 & 1979 & 0.9 & 234 & & 1 \\
\hline 15 & 44 & 0.0 & 46.0 & 5.9 & 13 & $i$ & & 0.0 & & & & 0.0 & & & 0.0 & 700 & & 1 \\
\hline
\end{tabular}




\begin{tabular}{|c|c|c|c|c|c|c|c|c|c|c|c|c|c|c|c|c|c|c|}
\hline Map & Lot & $\begin{array}{l}\text { Bldg. } \\
\text { Value }\end{array}$ & $\begin{array}{l}\text { Land } \\
\text { Value }\end{array}$ & Acres & $\begin{array}{l}\text { Land } \\
\text { Use }\end{array}$ & Zoning & $\begin{array}{l}\text { Bldg. } \\
\text { Grade }\end{array}$ & $\begin{array}{l}\text { \# of } \\
\text { Stories }\end{array}$ & $\begin{array}{l}\text { Occu- } \\
\text { pancy }\end{array}$ & $\begin{array}{l}\text { Heat } \\
\text { Type }\end{array}$ & $\begin{array}{l}\text { \# of } \\
\text { Beds }\end{array}$ & $\begin{array}{l}\text { \# of } \\
\text { Baths }\end{array}$ & $\begin{array}{l}\text { Total } \\
\text { Rooms }\end{array}$ & $\begin{array}{l}\text { Year } \\
\text { Built }\end{array}$ & $\begin{array}{l}\text { 1st } \\
\text { Floor }\end{array}$ & Frontage & $\begin{array}{l}\text { Wet- } \\
\text { lands }\end{array}$ & $\begin{array}{l}\text { Water- } \\
\text { shed }\end{array}$ \\
\hline 15 & 46 & 104.4 & 58.2 & 8.7 & 1 & 1 & 3 & 2.0 & 1 & 2 & 5 & 3.0 & 11 & 1900 & 1.1 & 800 & & 1 \\
\hline 15 & $46 \mathrm{~A}$ & 0.0 & 4.9 & 0.8 & 10 & 1 & & 0.0 & & & & 0.0 & & & 0.0 & 0 & & 1 \\
\hline 15 & 47 & 79.3 & 64.9 & 32.7 & 1 & 1 & 4 & 1.5 & 2 & 2 & 4 & 2.0 & 10 & 1800 & 1.3 & 0 & 1 & 1 \\
\hline 15 & $47 \mathrm{~A}$ & 0.0 & 139.9 & 23.3 & 10 & 1 & & 0.0 & & & & 0.0 & & & 0.0 & 0 & & 1 \\
\hline 15 & 48 & 0.0 & 55.8 & 28.9 & 13 & 1 & & 0.0 & & & & 0.0 & & & 0.0 & 700 & 1 & 1 \\
\hline 15 & $48 \mathrm{~A}$ & 0.0 & 49.2 & 15.5 & 13 & 1 & & 0.0 & & & & 0.0 & & & 0.0 & 300 & 1 & 1 \\
\hline 15 & 49 & 0.0 & 43.1 & 4.5 & 13 & 1 & & 0.0 & & & & 0.0 & & & 0.0 & 200 & 1 & 1 \\
\hline 15 & 50 & 0.0 & 112.0 & 120.0 & 13 & 1 & & 0.0 & & & & 0.0 & & & 0.0 & 2000 & & 1 \\
\hline 15 & 51 & 79.7 & 35.3 & 0.9 & 1 & 1 & 3 & 1.0 & 1 & 2 & 3 & 2.0 & 6 & 1955 & 1.2 & 200 & & 1 \\
\hline 15 & 52 & 0.0 & 92.5 & 80.0 & 13 & 1 & & 0.0 & & & & 0.0 & & & 0.0 & 2600 & 1 & 1 \\
\hline 16 & 1 & 91.1 & 74.4 & 28.0 & 1 & 1 & 3 & 1.5 & 1 & 2 & 3 & 1.5 & 7 & 1770 & 2.6 & 1350 & & \\
\hline 16 & 2 & 0.0 & 62.9 & 100.3 & 13 & 1 & & 0.0 & & & & 0.0 & & & 0.0 & 525 & & \\
\hline 16 & 3 & 0.0 & 61.5 & 20.0 & 13 & 1 & & 0.0 & & & & 0.0 & & & 0.0 & 450 & & \\
\hline 16 & 4 & 121.9 & 53.1 & 5.3 & 1 & 1 & 4 & 1.0 & 1 & 2 & 3 & 3.0 & 8 & 1977 & 1.5 & 300 & & \\
\hline 16 & $4 A$ & 70.5 & 61.4 & 11.1 & $i$ & 1 & 3 & 1.0 & 1 & 2 & 2 & 1.0 & 5 & 1976 & 1.0 & 700 & & \\
\hline 16 & 5 & 0.0 & 17.0 & 2.0 & 13 & 1 & & 0.0 & & & & 0.0 & & & 0.0 & 400 & & \\
\hline 16 & 6 & 78.5 & 50.0 & 4.3 & 1 & 1 & 3 & 1.0 & 1 & 2 & 2 & 1.0 & 4 & 1977 & 1.4 & 650 & & \\
\hline 16 & 7 & 0.0 & 7.4 & 1.0 & 13 & 1 & & 0.0 & & & & 0.0 & & & 0.0 & 400 & & \\
\hline 16 & 8 & 9.3 & 36.6 & 1.0 & 1 & 1 & 3 & 1.0 & 1 & 2 & 1 & 1.0 & 3 & 1966 & 0.6 & 250 & & \\
\hline 16 & 9 & 68.2 & 40.1 & 2.0 & $i$ & 1 & 3 & 1.0 & 1 & 3 & 4 & 2.0 & 7 & 1956 & 1.7 & 572 & & \\
\hline 16 & 10 & 61.1 & 47.3 & 3.5 & 1 & 1 & 3 & 1.5 & 1 & 2 & 2 & 1.5 & 5 & 1940 & 0.8 & 300 & & \\
\hline 16 & 11 & 71.6 & 43.0 & 2.6 & 1 & 1 & 4 & 1.0 & 1 & 4 & 2 & 1.0 & 4 & 1790 & 0.8 & 550 & & \\
\hline 16 & 12 & 0.0 & 32.0 & 1.5 & 15 & 1 & & 0.0 & & & & 0.0 & & & 0.0 & 400 & & \\
\hline 16 & 13 & 0.0 & 122.7 & 140.0 & 33 & 1 & & 0.0 & & & & 0.0 & & & 0.0 & 3800 & 1 & \\
\hline 16 & $13 \mathrm{~A}$ & 0.0 & 3.2 & 0.9 & 13 & 1 & & 0.0 & & & & 0.0 & & & 0.0 & 300 & & \\
\hline 16 & 15 & 96.4 & 38.9 & 2.2 & 1 & 1 & 3 & 1.5 & 1 & 2 & 3 & 2.0 & 6 & 1940 & 0.8 & 202 & & \\
\hline 16 & 15 & 96.4 & 0.0 & 0.0 & $i$ & 1 & 3 & 1.0 & 1 & 2 & 3 & 1.0 & 1 & 1940 & 1.2 & & & \\
\hline 16 & 16 & 68.8 & 53.7 & 7.1 & 1 & 1 & 3 & 1.0 & 1 & 4 & 3 & 1.0 & 5 & 1986 & 0.9 & 300 & & 1 \\
\hline 16 & $16 \mathrm{~A}$ & 88.2 & 56.4 & 8.8 & 1 & 1 & 3 & 1.0 & 1 & 2 & 3 & 1.5 & 6 & 1965 & 1.5 & 360 & & \\
\hline 16 & 17 & 57.6 & 41.8 & 3.0 & 1 & 1 & 3 & 2.0 & 1 & 2 & 2 & 1.0 & 6 & 1954 & 0.7 & 416 & & 1 \\
\hline 16 & 18 & 83.5 & 75.8 & 40.0 & 1 & 1 & 4 & 2.0 & 1 & 2 & 5 & 1.0 & 14 & 1800 & 1.3 & 1150 & & 1 \\
\hline 16 & 19 & 59.3 & 39.6 & 2.3 & 1 & 1 & 3 & 1.0 & $i$ & 2 & 3 & 1.0 & 6 & 1900 & 1.3 & 200 & & 1 \\
\hline 16 & 20 & 94.1 & 50.1 & 4.7 & 1 & 1 & 3 & 1.0 & 1 & 2 & 2 & 1.0 & 5 & 1984 & 1.1 & 320 & & 1 \\
\hline 16 & $20 \mathrm{~A}$ & 0.0 & 43.1 & 5.3 & 13 & 1 & & 0.0 & & & & 0.0 & & & 0.0 & 490 & & 1 \\
\hline 16 & 21 & 0.0 & 42.4 & 5.7 & 13 & 1 & & 0.0 & & & & 0.0 & & & 0.0 & 350 & & 1 \\
\hline 16 & $21 \mathrm{~A}$ & 0.0 & 50.7 & 10.6 & 13 & 1 & & 0.0 & & & & 0.0 & & & 0.0 & 670 & & 1 \\
\hline 16 & 21B & 107.7 & 47.8 & 4.2 & 1 & 1 & 3 & 1.5 & 1 & 2 & 3 & 2.0 & 7 & 1976 & 1.2 & 350 & 1 & 1 \\
\hline 16 & $21 \mathrm{C}$ & 147.9 & 51.6 & 5.7 & 2 & 1 & 5 & 1.0 & 2 & 2 & 5 & 2.0 & 15 & 1880 & 1.1 & 288 & & 1 \\
\hline 16 & 22 & 123.6 & 66.5 & 15.3 & 1 & i & 5 & 2.0 & 1 & 2 & 4 & 3.0 & 8 & 1750 & 1.1 & 630 & & 1 \\
\hline 16 & $22 \mathrm{~A}$ & 0.0 & 65.8 & 92.4 & 13 & 1 & & 0.0 & & & & 0.0 & & & 0.0 & 150 & 1 & 1 \\
\hline
\end{tabular}




\begin{tabular}{|c|c|c|c|c|c|c|c|c|c|c|c|c|c|c|c|c|c|c|}
\hline Map & Lot & $\begin{array}{l}\text { Bldg. } \\
\text { Value }\end{array}$ & $\begin{array}{l}\text { Land } \\
\text { Value }\end{array}$ & Acres & $\begin{array}{l}\text { Land } \\
\text { Use }\end{array}$ & Zoning & $\begin{array}{l}\text { Bldg. } \\
\text { Grade }\end{array}$ & $\begin{array}{l}\text { \# of } \\
\text { Stories }\end{array}$ & $\begin{array}{l}\text { Occu- } \\
\text { pancy }\end{array}$ & $\begin{array}{l}\text { Heat } \\
\text { Type }\end{array}$ & $\begin{array}{l}\text { \# of } \\
\text { Beds }\end{array}$ & $\begin{array}{l}\text { \#of } \\
\text { Baths }\end{array}$ & $\begin{array}{l}\text { Total } \\
\text { Rooms }\end{array}$ & $\begin{array}{l}\text { Year } \\
\text { Built }\end{array}$ & $\begin{array}{l}\text { 1xt } \\
\text { Floor }\end{array}$ & Frontage & $\begin{array}{l}\text { Wet- } \\
\text { lands }\end{array}$ & $\begin{array}{l}\text { Water- } \\
\text { shed }\end{array}$ \\
\hline 16 & 23 & 102.0 & 68.1 & 17.9 & 1 & 1 & 4 & 1.5 & 1 & 2 & 4 & 2.0 & 7 & 1985 & 1.0 & 300 & & 1 \\
\hline 16 & $23 \mathrm{~A}$ & 119.2 & 55.0 & 6.6 & $i$ & i & 4 & 1.5 & 1 & 2 & 4 & 2.0 & 7 & 1978 & 1.3 & 300 & & 1 \\
\hline 16 & $23 B$ & 98.0 & 66.8 & 15.7 & 1 & 1 & 4 & 1.0 & 1 & 4 & 3 & 2.0 & 6 & 1980 & 1.0 & 300 & & 1 \\
\hline 16 & $23 \mathrm{C}$ & 98.0 & 62.6 & 12.0 & $i$ & $i$ & 3 & 1.0 & 1 & 2 & 3 & 2.0 & 5 & 1979 & 1.8 & 300 & & 1 \\
\hline 16 & 23D & 103.4 & 67.1 & 16.2 & 1 & i & 4 & 2.0 & $i$ & 2 & 3 & 1.5 & 7 & 1985 & 0.8 & 300 & & 1 \\
\hline 16 & 24 & 5.4 & 44.6 & 3.1 & 11 & $i$ & & 0.0 & & & & 0.0 & & & 0.0 & 190 & & 1 \\
\hline 16 & 25 & 0.0 & 65.9 & 33.4 & 13 & 1 & & 0.0 & & & & 0.0 & & & 0.0 & 1000 & 1 & 1 \\
\hline 16 & $25 \mathrm{~A}$ & 126.4 & 53.5 & 5.6 & 1 & 1 & 4 & 1.5 & 1 & 2 & 4 & 2.5 & 7 & 1971 & 1.5 & 550 & & 1 \\
\hline 16 & $25 B$ & 165.1 & 54.5 & 6.3 & 1 & 1 & 5 & 2.0 & 1 & 2 & 4 & 2.5 & 8 & 1985 & 1.8 & 300 & & 1 \\
\hline 16 & $25 \mathrm{C}$ & 83.6 & 54.7 & 6.4 & $i$ & $i$ & 4 & 1.5 & 1 & 2 & 3 & 2.0 & 6 & 1985 & 0.8 & 300 & & 1 \\
\hline 16 & $25 \mathrm{D}$ & 106.3 & 52.9 & 5.2 & 1 & 1 & 5 & 3.0 & 1 & 2 & 3 & 1.5 & 5 & 1985 & 0.9 & 300 & & 1 \\
\hline 16 & $25 E$ & 206.0 & 57.3 & 8.2 & 1 & $i$ & 5 & 2.0 & 1 & 2 & 3 & 3.5 & 7 & 1986 & 1.7 & 320 & 1 & 1 \\
\hline 16 & $25 F$ & 0.0 & 50.1 & 8.7 & 13 & 1 & & 0.0 & & & & 0.0 & & & 0.0 & 300 & 1 & 1 \\
\hline 16 & $25 G$ & 106.2 & 59.9 & 10.1 & 1 & 1 & 4 & 3.0 & 1 & 2 & 2 & 1.0 & 5 & 1988 & 1.2 & 300 & 1 & 1 \\
\hline 16 & $25 \mathrm{H}$ & 127.8 & 50.3 & 4.8 & 1 & 1 & 4 & 2.0 & 1 & 2 & 3 & 2.5 & 7 & 1987 & 1.2 & 300 & & 1 \\
\hline 16 & 251 & 109.8 & 50.3 & 4.8 & 1 & 1 & 4 & 1.5 & 1 & 2 & 2 & 2.0 & 6 & 1988 & 1.4 & 300 & & 1 \\
\hline 16 & $25 \mathrm{~J}$ & 0.0 & 44.6 & 5.0 & 13 & 1 & & 0.0 & & & & 0.0 & & & 0.0 & 300 & & 1 \\
\hline 16 & 26 & 97.0 & 54.9 & 6.5 & 1 & 1 & 3 & 1.0 & 1 & 2 & 2 & 1.0 & 5 & 1930 & 2.0 & 400 & & $i$ \\
\hline 16 & 27 & 0.0 & 56.0 & 13.0 & 13 & 1 & & 0.0 & & & & 0.0 & & & 0.0 & 300 & & 1 \\
\hline 16 & $27 A$ & 102.8 & 51.6 & 4.6 & 1 & 1 & 3 & 2.0 & 1 & 2 & 3 & 2.0 & 7 & 1977 & 1.2 & 310 & & 1 \\
\hline 16 & $27 \mathrm{~B}$ & 86.3 & 68.2 & 18.0 & 1 & 1 & 4 & 1.5 & 1 & 2 & 2 & 1.0 & 7 & 1900 & 1.4 & 480 & & $i$ \\
\hline 16 & $27 \mathrm{C}$ & 144.3 & 53.7 & 5.7 & 1 & 1 & 5 & 1.5 & 1 & 2 & 2 & 2.0 & 6 & 1986 & 1.5 & 492 & 1 & 1 \\
\hline 16 & $27 \mathrm{D}$ & 166.7 & 67.0 & 17.5 & 1 & 1 & 4 & 1.0 & 1 & 2 & 3 & 2.5 & 9 & 1987 & 3.1 & 300 & 1 & 1 \\
\hline 16 & $27 E$ & 0.0 & 61.4 & 28.3 & 13 & 1 & & 0.0 & & & & 0.0 & & & 0.0 & 300 & 1 & 1 \\
\hline 16 & $27 \mathrm{~F}$ & 95.5 & 52.5 & 5.0 & 1 & 1 & 4 & 1.5 & 1 & 2 & 3 & 2.0 & 5 & 1988 & 1.0 & 300 & 1 & 1 \\
\hline 16 & $27 \mathrm{G}$ & 0.0 & 44.2 & 4.7 & 13 & 1 & & 0.0 & & & & 0.0 & & & 0.0 & 300 & $i$ & 1 \\
\hline 16 & $27 \mathrm{H}$ & 64.2 & 52.1 & 4.7 & 1 & 1 & 3 & 1.5 & 1 & 3 & 2 & 1.0 & 6 & 1988 & 0.9 & 300 & & 1 \\
\hline 16 & 271 & 135.8 & 63.4 & 12.6 & 1 & 1 & 4 & 2.0 & i & 2 & 4 & 2.0 & 8 & 1988 & 1.2 & 305 & & 1 \\
\hline 16 & 28 & 0.0 & 78.1 & 50.0 & 13 & 1 & & 0.0 & & & & 0.0 & & & 0.0 & 0 & & $i$ \\
\hline 16 & 29 & 108.2 & 64.7 & 13.5 & 1 & 1 & 3 & 1.0 & 1 & 2 & 2 & 1.5 & 5 & 1953 & 1.8 & 125 & & 1 \\
\hline 16 & 30 & 139.5 & 61.5 & 11.2 & 1 & 1 & 5 & 1.5 & 1 & 2 & 3 & 2.0 & 6 & 1977 & 1.4 & 392 & & 1 \\
\hline 16 & $30 \mathrm{~A}$ & 116.9 & 54.1 & 6.0 & 1 & 1 & 4 & 2.0 & 1 & 2 & 3 & 2.0 & 7 & 1975 & 1.1 & 320 & & $i$ \\
\hline 16 & $30 \mathrm{~B}$ & 91.8 & 53.6 & 5.6 & 1 & 1 & 4 & 1.5 & 1 & 4 & 2 & 2.0 & 6 & 1979 & 1.0 & 514 & & 1 \\
\hline 16 & 31 & 61.4 & 37.1 & 1.2 & 1 & 1 & 3 & 1.0 & 1 & 2 & 2 & 1.0 & 5 & 1945 & 1.0 & 240 & & 1 \\
\hline 16 & 32 & 101.5 & 69.9 & 20.5 & 1 & 1 & 3 & 1.0 & i & 1 & 3 & 2.0 & 6 & 1945 & 1.0 & 660 & 1 & 1 \\
\hline 16 & 33 & 57.4 & 78.1 & 35.0 & 1 & 1 & 3 & 1.0 & 1 & 2 & 3 & 1.0 & 5 & 1900 & 1.0 & 410 & & i \\
\hline 16 & 34 & 113.0 & 65.9 & 21.5 & 1 & 1 & 5 & 2.0 & 1 & 2 & 4 & 2.0 & 8 & 1800 & 1.0 & 580 & & 1 \\
\hline 16 & $34 \mathrm{~A}$ & 77.0 & 55.3 & 5.5 & 1 & 1 & 3 & 1.0 & 1 & 2 & 2 & 1.0 & 6 & 1983 & 1.1 & 400 & & 1 \\
\hline 16 & 35 & 73.9 & 60.8 & 10.7 & 1 & $i$ & 3 & 1.0 & 1 & 2 & 3 & 1.0 & 5 & 1980 & 1.2 & 430 & 1 & $i$ \\
\hline 16 & $35 A$ & 71.5 & 72.5 & 25.0 & 1 & 1 & 3 & 1.5 & 1 & 2 & 2 & 1.0 & 5 & 1979 & 0.8 & 400 & & 1 \\
\hline
\end{tabular}




\begin{tabular}{|c|c|c|c|c|c|c|c|c|c|c|c|c|c|c|c|c|c|c|}
\hline Map & Lot & $\begin{array}{l}\text { Bldg. } \\
\text { Value }\end{array}$ & $\begin{array}{l}\text { Land } \\
\text { Value }\end{array}$ & Acres & $\begin{array}{l}\text { Land } \\
\text { Use }\end{array}$ & Zoning & $\begin{array}{l}\text { Bldg. } \\
\text { Grade }\end{array}$ & $\begin{array}{l}\text { of } \\
\text { Stories }\end{array}$ & $\begin{array}{l}\text { Occu- } \\
\text { pancy }\end{array}$ & $\begin{array}{l}\text { Heat } \\
\text { Type }\end{array}$ & $\begin{array}{l}\text { "of } \\
\text { Beds }\end{array}$ & $\begin{array}{l}\text { "of } \\
\text { Baths }\end{array}$ & $\begin{array}{l}\text { Total } \\
\text { Rooms }\end{array}$ & $\begin{array}{l}\text { Year } \\
\text { Built }\end{array}$ & $\begin{array}{l}\text { lst } \\
\text { Floor }\end{array}$ & Frontage & $\begin{array}{l}\text { Wet- } \\
\text { lands }\end{array}$ & $\begin{array}{l}\text { Water- } \\
\text { shed }\end{array}$ \\
\hline 16 & 37 & 30.4 & 52.1 & 4.6 & 1 & 1 & 2 & 1.0 & 1 & 1 & 1 & 1.0 & 2 & 1900 & 0.7 & 300 & & 1 \\
\hline 16 & $37 \mathrm{~A}$ & 0.0 & 52.2 & 4.7 & 13 & 1 & & 0.0 & & & & 0.0 & & & 0.0 & 300 & & 1 \\
\hline 16 & $37 \mathrm{~B}$ & 0.0 & 52.2 & 4.7 & 13 & 1 & & 0.0 & & & & 0.0 & & & 0.0 & 300 & & 1 \\
\hline 16 & $37 \mathrm{C}$ & 0.0 & 52.5 & 5.0 & 1 & 1 & & 0.0 & & & & 0.0 & & & 0.0 & 310 & & 1 \\
\hline 16 & 37D & 0.0 & 52.5 & 5.0 & 1 & 1 & & 0.0 & & & & 0.0 & & & 0.0 & 325 & & 1 \\
\hline 16 & 38 & 82.1 & 70.8 & 24.8 & 1 & 1 & 4 & 1.0 & 1 & 2 & 3 & 1.0 & 5 & 1821 & 1.0 & 920 & 1 & 1 \\
\hline 16 & $38 \mathrm{~A}$ & 111.2 & 67.7 & 17.0 & 1 & 1 & 4 & 2.0 & 1 & 2 & 3 & 2.0 & 6 & 1980 & 1.0 & 460 & 1 & 1 \\
\hline 16 & 38B & 81.2 & 53.4 & 5.5 & 1 & 1 & 3 & 1.5 & 1 & 2 & 3 & 1.0 & 2 & 1978 & 1.0 & & & 1 \\
\hline 16 & $38 \mathrm{C}$ & 76.1 & 58.9 & 9.2 & i & $i$ & 3 & 1.0 & 1 & 2 & 3 & 1.0 & 6 & 1977 & 1.2 & 300 & 1 & 1 \\
\hline 16 & 38D & 0.0 & 5.1 & 0.4 & 13 & 1 & & 0.0 & & & & 0.0 & & & 0.0 & 460 & 1 & 1 \\
\hline 16 & 39 & 73.3 & 41.2 & 2.3 & 1 & 1 & 3 & 1.0 & 1 & 2 & 2 & 1.0 & 4 & 1979 & 1.0 & 200 & & 1 \\
\hline 16 & 40 & 180.3 & 50.5 & 5.0 & 1 & 1 & 5 & 2.0 & 1 & 4 & 4 & 4.0 & 10 & 1974 & 1.8 & 973 & & 1 \\
\hline 16 & 41 & 8.6 & 43.1 & 3.1 & 1 & 1 & 3 & 1.0 & 1 & 2 & 2 & 1.0 & 4 & 1970 & 0.9 & 260 & & 1 \\
\hline 16 & 42 & 104.1 & 48.4 & 4.3 & 1 & 1 & 3 & 1.0 & 1 & 2 & 3 & 2.0 & 6 & 1987 & 1.4 & 340 & & 1 \\
\hline 16 & 43 & 60.0 & 53.2 & 6.7 & 1 & 1 & 2 & 1.0 & 1 & 2 & 4 & 1.0 & 10 & 1955 & 1.8 & 600 & & 1 \\
\hline 16 & 44 & 80.7 & 45.5 & 3.7 & 6 & 1 & 3 & 0.0 & 1 & 2 & & 0.0 & & 1958 & 1.5 & 335 & & 1 \\
\hline 16 & 45 & 80.9 & 41.8 & 3.0 & 1 & 1 & 3 & 1.0 & 1 & 2 & 2 & 1.5 & 6 & 1973 & 1.2 & 250 & & 1 \\
\hline 16 & 46 & 12.8 & 39.1 & 2.3 & 1 & 1 & 3 & 1.0 & 1 & 3 & 2 & 1.0 & 4 & 1961 & 1.0 & 500 & & \\
\hline 16 & 47 & 133.0 & 50.1 & 4.7 & 1 & 1 & 4 & 2.0 & 1 & 2 & 4 & 2.5 & 8 & 1970 & 1.4 & 400 & & \\
\hline 16 & 48 & 0.0 & 50.1 & 10.0 & 79 & 1 & & 0.0 & & & & 0.0 & & & 0.0 & 50 & & \\
\hline 16 & 49 & 0.0 & 289.8 & 222.9 & 13 & $i$ & & 0.0 & & & & 0.0 & & & 0.0 & 550 & & 1 \\
\hline 16 & $49 \mathrm{~A}$ & 110.6 & 50.1 & 4.6 & 1 & 1 & 4 & 2.0 & 1 & 2 & 4 & 2.0 & 8 & 1955 & 1.5 & 375 & & \\
\hline 16 & $49 B$ & 72.5 & 50.9 & 5.2 & 1 & 1 & 3 & 1.0 & 1 & 2 & 3 & 1.5 & 5 & 1979 & 1.1 & 300 & & \\
\hline 16 & $49 \mathrm{C}$ & 70.4 & 50.9 & 5.2 & 1 & 1 & 3 & 1.0 & 1 & 2 & 3 & 2.0 & 6 & 1978 & 0.9 & 300 & & \\
\hline 16 & 49D & 24.6 & 53.3 & 6.9 & 1 & 1 & 3 & 1.0 & 1 & 1 & 1 & 1.0 & 3 & 1940 & 0.4 & 410 & & \\
\hline 16 & 50 & 117.0 & 35.8 & 1.4 & 1 & 1 & 4 & 2.0 & 1 & 2 & 4 & 3.0 & 7 & 1960 & 1.5 & 150 & & \\
\hline 16 & 51 & 0.0 & 31.0 & 1.6 & 13 & 1 & & 0.0 & & & & 0.0 & & & 0.0 & 300 & & \\
\hline 16 & 52 & 52.6 & 51.4 & 5.5 & 1 & 1 & 3 & 1.0 & 1 & 2 & 2 & 1.0 & 4 & 1942 & 0.8 & 169 & & \\
\hline 16 & 53 & 81.9 & 67.6 & 17.2 & 1 & 1 & 3 & 1.0 & 1 & 2 & 3 & 1.0 & 5 & 1984 & 1.0 & 694 & & \\
\hline 16 & $53 \mathrm{~A}$ & 79.3 & 50.0 & 4.6 & 1 & 1 & 3 & 1.5 & 1 & 2 & 3 & 2.0 & 7 & 1988 & 0.9 & 300 & & \\
\hline 16 & 53B & 0.0 & 50.1 & 4.7 & 13 & 1 & & 0.0 & & & & 0.0 & & & 0.0 & 744 & & \\
\hline 16 & 54 & 0.0 & 47.6 & 7.0 & 13 & 1 & & 0.0 & & & & 0.0 & & & 0.0 & 466 & & \\
\hline 16 & 55 & 163.1 & 80.8 & 49.2 & 1 & 1 & 4 & 1.0 & 1 & 4 & 3 & 2.5 & 7 & 1972 & 2.4 & 400 & & \\
\hline 16 & 56 & 118.0 & 81.0 & 40.7 & 1 & 1 & 3 & 2.0 & 1 & 2 & 3 & 2.0 & 6 & 1940 & 1.1 & 500 & & \\
\hline 16 & 58 & 195.6 & 98.7 & 73.4 & 1 & 1 & 6 & 2.0 & 1 & 2 & 4 & 2.5 & 8 & 1966 & 1.6 & 900 & & \\
\hline 16 & 59 & 46.9 & 44.4 & 3.0 & 1 & 1 & 3 & 1.5 & 1 & 2 & 2 & 1.0 & 4 & 1950 & 0.6 & 759 & & \\
\hline 16 & 60 & 0.0 & 76.5 & 56.0 & 13 & 1 & & 0.0 & & & & 0.0 & & & 0.0 & 450 & & \\
\hline 16 & 61 & 52.7 & 56.2 & 7.3 & 1 & 1 & 3 & 1.0 & 1 & 4 & 1 & 1.0 & 6 & 1945 & 1.1 & 420 & & \\
\hline 16 & 62 & 77.2 & 60.1 & 10.0 & 1 & 1 & 3 & 1.0 & 1 & 2 & 3 & 1.0 & 6 & 1986 & 1.3 & 350 & & \\
\hline 16 & $62 \mathrm{~A}$ & 0.0 & 31.3 & 1.1 & 13 & $i$ & & 0.0 & & & & 0.0 & & & 0.0 & 400 & & \\
\hline
\end{tabular}




\begin{tabular}{|c|c|c|c|c|c|c|c|c|c|c|c|c|c|c|c|c|c|c|}
\hline Map & Lot & $\begin{array}{l}\text { Bldg. } \\
\text { Value }\end{array}$ & $\begin{array}{l}\text { Land } \\
\text { Value }\end{array}$ & Acres & $\begin{array}{l}\text { Land } \\
\text { Use }\end{array}$ & Zoning & $\begin{array}{l}\text { Bldg. } \\
\text { Grade }\end{array}$ & $\begin{array}{l}\text { \# of } \\
\text { Stories }\end{array}$ & $\begin{array}{l}\text { Occu- } \\
\text { pancy }\end{array}$ & $\begin{array}{l}\text { Heat } \\
\text { Type }\end{array}$ & $\begin{array}{l}\text { \# of } \\
\text { Beds }\end{array}$ & $\begin{array}{l}\text { \# of } \\
\text { Baths }\end{array}$ & $\begin{array}{l}\text { Total } \\
\text { Rooms }\end{array}$ & $\begin{array}{l}\text { Year } \\
\text { Built }\end{array}$ & $\begin{array}{l}\text { 1st } \\
\text { Floor }\end{array}$ & Frontage & $\begin{array}{l}\text { Wet- } \\
\text { lands }\end{array}$ & $\begin{array}{l}\text { Water- } \\
\text { shed }\end{array}$ \\
\hline 16 & 62B & 72.4 & 54.1 & 6.0 & 1 & 1 & 3 & 1.5 & 1 & 4 & 3 & 1.5 & 5 & 1986 & 1.0 & 670 & & \\
\hline 16 & $62 \mathrm{C}$ & 0.0 & 43.1 & 4.5 & 13 & 1 & & 0.0 & & & & 0.0 & & & 0.0 & 480 & & \\
\hline 16 & 63 & 67.1 & 52.9 & 5.2 & 1 & 1 & 3 & 1.0 & 1 & 2 & 2 & 1.0 & 4 & 1985 & 0.9 & 300 & & \\
\hline 16 & 64 & 279.1 & 119.7 & 118.0 & 1 & 1 & 6 & 1.5 & 1 & 2 & 2 & 2.0 & 5 & 1987 & 2.6 & 1030 & & 1 \\
\hline 16 & 65 & 0.0 & 45.4 & 5.5 & 13 & 1 & & 0.0 & & & & 0.0 & & & 0.0 & 559 & & 1 \\
\hline 16 & $65 \mathrm{~A}$ & 172.0 & 54.7 & 6.4 & 12 & 1 & 5 & 2.0 & 1 & 2 & 3 & 2.5 & 9 & 1971 & 1.8 & 731 & & 1 \\
\hline 16 & 66 & 0.0 & 9.0 & 6.0 & 15 & 1 & & 0.0 & & & & 0.0 & & & 0.0 & 0 & & \\
\hline 16 & 67 & 0.0 & 63.1 & 22.5 & 13 & 1 & & 0.0 & & & & 0.0 & & & 0.0 & 500 & & \\
\hline 16 & 68 & 118.7 & 68.8 & 19.0 & 1 & 1 & 4 & 2.0 & 1 & 2 & 3 & 1.5 & 7 & 1989 & 1.4 & 600 & & \\
\hline 16 & 70 & 0.0 & 21.9 & 22.0 & 13 & 1 & & 0.0 & & & & 0.0 & & & 0.0 & 0 & & \\
\hline 16 & 71 & 0.0 & 15.8 & 12.0 & 15 & 1 & & 0.0 & & & & 0.0 & & & 0.0 & 0 & & \\
\hline 16 & 72 & 0.0 & 30.9 & 1.0 & 80 & 1 & & 0.0 & & & & 0.0 & & & 0.0 & 525 & & \\
\hline 17 & 1 & 52.0 & 36.6 & 1.0 & 1 & 1 & 3 & 1.0 & 1 & 2 & 1 & 1.0 & 5 & 1910 & 0.8 & 250 & 1 & 1 \\
\hline 17 & 2 & 119.7 & 54.3 & 6.1 & 1 & 1 & 5 & 1.5 & 1 & 2 & 2 & 1.0 & 7 & 1825 & 1.1 & & & 1 \\
\hline 17 & 3 & 106.1 & 73.4 & 26.6 & 1 & 1 & 3 & 2.0 & 1 & 3 & 3 & 2.0 & 5 & 1972 & 1.2 & 336 & 1 & 1 \\
\hline 17 & 4 & 84.9 & 44.4 & 3.0 & 1 & 1 & 4 & 2.0 & 1 & 2 & 3 & 1.5 & 6 & 1982 & 0.8 & 75 & & 1 \\
\hline 17 & 5 & 93.6 & 55.6 & 7.0 & 1 & 1 & 4 & 2.0 & 1 & 2 & 3 & 1.5 & 6 & 1986 & 1.0 & 300 & & 1 \\
\hline 17 & 6 & 175.7 & 76.1 & 31.0 & 1 & 1 & 5 & 2.0 & 1 & 2 & 4 & 2.0 & 10 & 1938 & 1.3 & 800 & & 1 \\
\hline 17 & 7 & 0.0 & 32.1 & 1.3 & 13 & 1 & & 0.0 & & & & 0.0 & & & 0.0 & 750 & & 1 \\
\hline 17 & 8 & 90.7 & 58.7 & 10.7 & 1 & 3 & 3 & 1.0 & 1 & 2 & 5 & 2.0 & 9 & 1845 & 1.1 & 1350 & & 1 \\
\hline 17 & 9 & 94.0 & 34.8 & 1.0 & 1 & 3 & 3 & 1.0 & 1 & 2 & 3 & 2.0 & 6 & 1970 & 1.2 & 299 & & 1 \\
\hline 17 & 10 & 14.5 & 31.4 & 0.8 & 5 & 3 & 1 & 0.0 & & 1 & & 0.0 & & 1945 & 3.7 & 200 & & 1 \\
\hline 17 & 11 & 0.0 & 3.5 & 1.2 & 13 & 3 & & 0.0 & & & & 0.0 & & & 0.0 & 1100 & & 1 \\
\hline 17 & 13 & 0.0 & 5.7 & 0.4 & 13 & 1 & & 0.0 & & & & 0.0 & & & 0.0 & 400 & & 1 \\
\hline 17 & 14 & 118.4 & 31.4 & 0.7 & 1 & 1 & 3 & 1.0 & 1 & 2 & 3 & 2.0 & 9 & 1975 & 2.0 & 510 & & 1 \\
\hline 17 & 15 & 0.0 & 5.7 & 0.4 & 13 & 1 & & 0.0 & & & & 0.0 & & & 0.0 & 600 & & 1 \\
\hline 17 & 16 & 88.5 & 31.4 & 0.8 & 1 & 1 & 3 & 1.0 & 1 & 2 & 3 & 2.0 & 6 & 1964 & 1.8 & 250 & & 1 \\
\hline 17 & 17 & 0.0 & 3.8 & 0.3 & 13 & 1 & & 0.0 & & & & 0.0 & & & 0.0 & 150 & & 1 \\
\hline 17 & 18 & 90.5 & 50.6 & 5.0 & 1 & i & 3 & 1.0 & 1 & 2 & 3 & 2.0 & 6 & 1970 & 1.5 & 450 & & 1 \\
\hline 17 & 19 & 55.8 & 29.4 & 0.6 & 1 & 1 & 3 & 1.0 & 1 & 2 & 2 & 1.0 & 4 & 1964 & 0.8 & 50 & 1 & 1 \\
\hline 17 & 20 & 95.6 & 31.4 & 0.6 & 3 & i & 3 & 1.0 & 6 & 2 & & 0.0 & & 1980 & 1.9 & 250 & 1 & 1 \\
\hline 17 & 21 & 120.6 & 52.1 & 6.0 & 1 & 1 & 3 & 1.5 & 1 & 2 & 3 & 2.5 & 7 & 1980 & 1.8 & 414 & 1 & 1 \\
\hline 17 & 22 & 0.0 & 59.6 & 21.3 & 13 & 1 & & 0.0 & & & & 0.0 & & & 0.0 & 425 & 1 & 1 \\
\hline 17 & $22 \mathrm{~A}$ & 0.0 & 58.8 & 21.3 & 13 & 1 & & 0.0 & & & & 0.0 & & & 0.0 & 425 & 1 & 1 \\
\hline 17 & 23 & 99.0 & 55.7 & 8.4 & 1 & 1 & 3 & 2.0 & 1 & 3 & 4 & 2.5 & 7 & 1988 & 0.9 & 300 & & 1 \\
\hline 17 & $23 \mathrm{~A}$ & 0.0 & 49.4 & 9.5 & 13 & 1 & & 0.0 & & & & 0.0 & & & 0.0 & & & 1 \\
\hline 17 & $23 \mathrm{~B}$ & 0.0 & 50.8 & 10.7 & 13 & 1 & & 0.0 & & & & 0.0 & & & 0.0 & & & 1 \\
\hline 17 & $23 C$ & 0.0 & 45.1 & 6.6 & 13 & 1 & & 0.0 & & & & 0.0 & & & 0.0 & & & 1 \\
\hline 17 & $23 D$ & 0.0 & 45.8 & 7.2 & 13 & 1 & & 0.0 & & & & 0.0 & & & 0.0 & & & 1 \\
\hline 17 & 24 & 112.6 & 88.5 & 62.2 & 1 & 1 & 5 & 1.0 & 1 & 2 & 3 & 1.5 & 9 & 1779 & 1.4 & 1655 & 1 & 1 \\
\hline
\end{tabular}




\begin{tabular}{|c|c|c|c|c|c|c|c|c|c|c|c|c|c|c|c|c|c|c|}
\hline Map & Lot & $\begin{array}{l}\text { Bldg. } \\
\text { Value }\end{array}$ & $\begin{array}{l}\text { Land } \\
\text { Value }\end{array}$ & Acres & $\begin{array}{l}\text { Land } \\
\text { Use }\end{array}$ & Zoning & $\begin{array}{l}\text { Bldg. } \\
\text { Grade }\end{array}$ & $\begin{array}{l}\text { of } \\
\text { Stories }\end{array}$ & $\begin{array}{l}\text { Occu- } \\
\text { pancy }\end{array}$ & $\begin{array}{l}\text { Heat } \\
\text { Type }\end{array}$ & $\begin{array}{l}\text { "of } \\
\text { Beds }\end{array}$ & $\begin{array}{l}\text { \# of } \\
\text { Baths }\end{array}$ & $\begin{array}{l}\text { Total } \\
\text { Rooms }\end{array}$ & $\begin{array}{l}\text { Year } \\
\text { Built }\end{array}$ & $\begin{array}{l}\text { 1 st } \\
\text { Floor }\end{array}$ & Frontage & $\begin{array}{l}\text { Wet- } \\
\text { lands }\end{array}$ & $\begin{array}{l}\text { Waler- } \\
\text { shed }\end{array}$ \\
\hline 17 & $24 \mathrm{~A}$ & 0.0 & 52.7 & 8.8 & 10 & 1 & & 0.0 & & & & 0.0 & & & 0.0 & 0 & 1 & 1 \\
\hline 17 & 25 & 85.7 & 50.1 & 4.7 & 1 & 1 & 5 & 1.0 & 1 & 2 & 3 & 1.5 & 6 & 1850 & 1.0 & 942 & & 1 \\
\hline 17 & $25 \mathrm{~A}$ & 0.0 & 41.2 & 4.5 & 13 & 1 & & 0.0 & & & & 0.0 & & & 0.0 & 0 & & $i$ \\
\hline 17 & 26 & 76.7 & 44.2 & 2.9 & 1 & 1 & 3 & 1.0 & 1 & 2 & 3 & 1.0 & 6 & 1974 & 1.3 & 281 & & 1 \\
\hline 17 & 27 & 49.7 & 52.5 & 4.9 & 1 & 1 & 3 & 1.0 & $i$ & 2 & 2 & 1.0 & 6 & 1958 & 1.0 & 318 & & 1 \\
\hline 17 & 28 & 52.0 & 52.5 & 4.9 & i & 1 & 3 & 1.0 & 1 & 2 & 1 & 1.0 & 4 & 1955 & 0.9 & 306 & & 1 \\
\hline 17 & 30 & 75.7 & 56.2 & 7.4 & 1 & 1 & 3 & 1.0 & 1 & 2 & 3 & 2.0 & 6 & 1930 & 1.2 & 520 & & 1 \\
\hline 17 & $30 \mathrm{~A}$ & 0.0 & 4.6 & 0.3 & 13 & 1 & & 0.0 & & & & 0.0 & & & 0.0 & 21 & & 1 \\
\hline 17 & $30 \mathrm{~B}$ & 176.9 & 52.0 & 4.6 & 1 & 1 & 4 & 1.0 & 1 & 2 & 3 & 2.5 & 8 & 1989 & 3.4 & 300 & & $i$ \\
\hline 17 & 31 & 81.1 & 41.8 & 2.5 & 1 & 1 & 3 & 1.5 & 1 & 2 & 3 & 1.5 & 6 & 1930 & 1.1 & 330 & & 1 \\
\hline 17 & 32 & 57.6 & 64.4 & 13.3 & 1 & 1 & 3 & 1.0 & 1 & 2 & 3 & 1.0 & 5 & 1981 & 0.8 & 50 & 1 & 1 \\
\hline 17 & $32 \mathrm{~A}$ & 0.0 & 12.0 & 2.0 & 10 & 1 & & 0.0 & & & & 0.0 & & & 0.0 & 0 & 1 & 1 \\
\hline 17 & 33 & 0.0 & 69.7 & 34.5 & 13 & 1 & & 0.0 & & & & 0.0 & & & 0.0 & 1200 & 1 & 1 \\
\hline 17 & $33 \mathrm{~A}$ & 0.0 & 9.2 & 1.5 & 10 & 1 & & 0.0 & & & & 0.0 & & & 0.0 & 0 & 1 & 1 \\
\hline 17 & 34 & 114.0 & 70.8 & 44.1 & 6 & 1 & 3 & 0.0 & 1 & 1 & & 0.0 & & 1977 & 5.4 & 1250 & $i$ & 1 \\
\hline 17 & $34 \mathrm{~A}$ & 0.0 & 32.0 & 5.3 & 10 & 1 & & 0.0 & & & & 0.0 & & & 0.0 & 0 & & 1 \\
\hline 17 & $34 B$ & 0.0 & 3.3 & 0.5 & 10 & 1 & & 0.0 & & & & 0.0 & & & 0.0 & 0 & & 1 \\
\hline 17 & $34 \mathrm{C}$ & 89.7 & 52.6 & 5.0 & 1 & 1 & 3 & 1.5 & 1 & 2 & 1 & 1.0 & 5 & 1985 & 1.5 & 0 & & 1 \\
\hline 17 & $34 D$ & 0.0 & 44.6 & 5.0 & 13 & $i$ & & 0.0 & & & & 0.0 & & & 0.0 & & & 1 \\
\hline 17 & 35 & 0.0 & 31.3 & 38.5 & 13 & 1 & & 0.0 & & & & 0.0 & & & 0.0 & 0 & & 1 \\
\hline 17 & $35 \mathrm{~A}$ & 0.0 & 112.2 & 18.7 & 10 & 1 & & 0.0 & & & & 0.0 & & & 0.0 & 0 & 1 & $i$ \\
\hline 17 & 36 & 73.8 & 55.6 & 7.0 & 1 & 1 & 3 & 1.0 & 1 & 4 & 3 & 1.0 & 6 & 1987 & 1.2 & 900 & 1 & 1 \\
\hline 17 & 37 & 35.3 & 53.4 & 5.5 & 1 & 1 & 4 & 1.5 & 1 & 2 & 3 & 2.0 & 7 & 1989 & 1.2 & 150 & 1 & 1 \\
\hline 17 & 38 & 15.2 & 36.4 & 1.0 & 1 & 1 & 3 & 1.0 & 1 & 2 & 2 & 1.0 & 5 & 1976 & 0.8 & 186 & & 1 \\
\hline 17 & 39 & 97.0 & 112.9 & 101.4 & $i$ & 1 & 4 & 1.5 & 1 & 2 & 4 & 1.0 & 9 & 1870 & 1.4 & 1850 & & 1 \\
\hline 17 & $39 \mathrm{~A}$ & 0.0 & 61.5 & 20.0 & 13 & 1 & & 0.0 & & & & 0.0 & & & 0.0 & 1200 & 1 & 1 \\
\hline 17 & 40 & 0.0 & 68.7 & 32.3 & 13 & 1 & & 0.0 & & & & 0.0 & & & 0.0 & 1000 & 1 & i \\
\hline 17 & $40 \mathrm{~A}$ & 0.0 & 190.3 & 31.7 & 10 & 1 & & 0.0 & & & & 0.0 & & & 0.0 & & & 1 \\
\hline 17 & 41 & 234.1 & 63.6 & 13.0 & 80 & 1 & 3 & 0.0 & & 2 & & 0.0 & & 1955 & 7.6 & 260 & & 1 \\
\hline 17 & 42 & 0.0 & 113.8 & 122.0 & 13 & 1 & & 0.0 & & & & 0.0 & & & 0.0 & 125 & 1 & 1 \\
\hline 17 & $42 A$ & 0.0 & 42.5 & 3.9 & 13 & 1 & & 0.0 & & & & 0.0 & & & 0.0 & 950 & & 1 \\
\hline 17 & 44 & 34.3 & 52.6 & 5.0 & 1 & 1 & 2 & 1.0 & 1 & 1 & 3 & 1.0 & 5 & 1916 & 0.8 & 1050 & & i \\
\hline 17 & 45 & 66.7 & 76.2 & 31.6 & 1 & 1 & 3 & 1.0 & 1 & 2 & 3 & 1.0 & 5 & 1925 & 0.6 & 579 & 1 & 1 \\
\hline 17 & 46 & 84.3 & 53.2 & 5.4 & 1 & 1 & 3 & 1.0 & 1 & 2 & 3 & 1.0 & 6 & 1988 & 1.3 & 960 & & i \\
\hline 17 & $46 \mathrm{~A}$ & 0.0 & 3.5 & 2.4 & 13 & $i$ & & 0.0 & & & & 0.0 & & & 0.0 & 0 & & 1 \\
\hline 17 & $46 B$ & 68.2 & 52.5 & 4.9 & 1 & 1 & 3 & 1.0 & 1 & 4 & 2 & 1.0 & 4 & 1987 & 1.1 & 300 & & $i$ \\
\hline 17 & $46 \mathrm{C}$ & 110.9 & 52.1 & 4.6 & 1 & 1 & 3 & 2.0 & 1 & 2 & 3 & 2.0 & 7 & 1987 & 1.2 & 300 & & 1 \\
\hline 17 & 47 & 84.4 & 42.5 & 2.5 & 1 & 1 & 3 & 1.0 & 1 & 2 & 3 & 1.0 & 6 & 1987 & 1.2 & 266 & & 1 \\
\hline 17 & $47 \mathrm{~A}$ & 0.0 & 7.7 & 1.5 & 13 & 1 & & 0.0 & & & & 0.0 & & & 0.0 & & & 1 \\
\hline 17 & 47AA & 65.1 & 16.3 & 0.2 & 1 & 1 & 3 & 1.0 & 1 & 2 & 3 & 1.0 & 6 & 1958 & 1.6 & & & 1 \\
\hline
\end{tabular}




\begin{tabular}{|c|c|c|c|c|c|c|c|c|c|c|c|c|c|c|c|c|c|c|}
\hline Map & Lot & $\begin{array}{l}\text { Bldg. } \\
\text { Value }\end{array}$ & $\begin{array}{l}\text { Land } \\
\text { Value }\end{array}$ & Acres & $\begin{array}{l}\text { Land } \\
\text { Use }\end{array}$ & Zoning & $\begin{array}{l}\text { Bldg. } \\
\text { Grade }\end{array}$ & $\begin{array}{l}\text { "of } \\
\text { Stories }\end{array}$ & $\begin{array}{l}\text { Occu- } \\
\text { pancy }\end{array}$ & $\begin{array}{l}\text { Heat } \\
\text { Type }\end{array}$ & $\begin{array}{l}\text { of } \\
\text { Beds }\end{array}$ & $\begin{array}{l}\text { of } \\
\text { Baths }\end{array}$ & $\begin{array}{l}\text { Total } \\
\text { Rooms }\end{array}$ & $\begin{array}{l}\text { Year } \\
\text { Built }\end{array}$ & $\begin{array}{l}\text { 18t } \\
\text { Floor }\end{array}$ & Frontage & $\begin{array}{l}\text { Wet- } \\
\text { lands }\end{array}$ & $\begin{array}{l}\text { Water- } \\
\text { shed }\end{array}$ \\
\hline 17 & $47 \mathrm{AB}$ & 56.9 & 16.3 & 0.2 & 1 & 1 & 3 & 1.0 & 1 & 2 & 3 & 1.0 & 5 & 1958 & 1.2 & & & 1 \\
\hline 17 & 47AC & 65.5 & 18.2 & 0.2 & 1 & 1 & 3 & 1.0 & 1 & 2 & 3 & 1.0 & 6 & 1959 & 1.6 & & & 1 \\
\hline 17 & $47 \mathrm{AD}$ & 57.8 & 19.0 & 0.2 & 1 & 1 & 3 & 1.0 & 1 & 2 & 3 & 1.0 & 5 & 1958 & 1.2 & & & 1 \\
\hline 17 & $47 \mathrm{AE}$ & 66.3 & 20.0 & 0.3 & 1 & 1 & 3 & 1.0 & 1 & 2 & 3 & 1.0 & 5 & 1958 & 1.6 & & & 1 \\
\hline 17 & 47AF & 60.6 & 18.2 & 0.2 & 1 & 1 & 3 & 1.0 & 1 & 2 & 3 & 1.0 & 5 & 1958 & 1.2 & & & 1 \\
\hline 17 & 47AG & 60.4 & 20.0 & 0.3 & 1 & 1 & 3 & 1.0 & 1 & 2 & 3 & 1.0 & 5 & 1958 & 1.2 & & & 1 \\
\hline 17 & $47 \mathrm{AH}$ & 67.4 & 16.3 & 0.2 & 1 & 1 & 3 & 1.0 & 1 & 2 & 3 & 1.0 & 5 & 1958 & 1.2 & & & 1 \\
\hline 17 & $47 A$ & 61.4 & 22.0 & 0.3 & 1 & 1 & 3 & 1.0 & 1 & 2 & 3 & 1.0 & 5 & 1958 & 1.2 & & & 1 \\
\hline 17 & 47AK & 62.9 & 18.2 & 0.2 & 1 & 1 & 3 & 1.0 & 1 & 2 & 3 & 1.0 & 5 & 1958 & 1.2 & & & 1 \\
\hline 17 & $47 \mathrm{AM}$ & 67.5 & 21.2 & 0.3 & 1 & 1 & 3 & 1.0 & 1 & 2 & 3 & 1.0 & 7 & 1959 & 1.6 & & & 1 \\
\hline 17 & 47AN & 65.6 & 18.2 & 0.2 & 1 & 1 & 3 & 1.0 & 1 & 2 & 3 & 1.0 & 5 & 1959 & 1.2 & & & 1 \\
\hline 17 & 47AP & 63.5 & 20.0 & 0.2 & 1 & 1 & 3 & 1.0 & 1 & 2 & 3 & 1.0 & 6 & 1959 & 1.4 & & & 1 \\
\hline 17 & $47 \mathrm{AQ}$ & 57.2 & 19.7 & 0.2 & 1 & 1 & 3 & 1.0 & 1 & 2 & 3 & 1.0 & 5 & 1959 & 1.2 & & & 1 \\
\hline 17 & 47AR & 59.3 & 18.2 & 0.2 & 1 & 1 & 3 & 1.0 & 1 & 2 & 3 & 1.0 & 5 & 1958 & 1.2 & & & 1 \\
\hline 17 & 48 & 50.8 & 53.0 & 6.0 & 1 & 1 & 3 & 1.5 & 1 & 2 & 2 & 1.0 & 4 & 1910 & 0.5 & 550 & & 1 \\
\hline 17 & 49 & 39.4 & 42.5 & 2.5 & 1 & 1 & 3 & 1.0 & 1 & 4 & 3 & 1.0 & 6 & 1950 & 1.0 & 250 & & 1 \\
\hline 17 & 50 & 108.0 & 40.3 & 2.5 & 6 & 1 & 3 & 0.0 & 6 & 4 & & 0.0 & & 1957 & 2.2 & 690 & & 1 \\
\hline 17 & 51 & 75.6 & 47.0 & 4.0 & 1 & 1 & 3 & 1.0 & 1 & 2 & 1 & 1.0 & 4 & 1953 & 1.3 & 150 & & 1 \\
\hline 17 & 52 & 142.5 & 60.9 & 17.5 & 1 & 5 & 4 & 1.0 & 1 & 2 & 4 & 2.0 & 8 & 1970 & 2.3 & 550 & & 1 \\
\hline 17 & 53 & 41.3 & 44.0 & 3.5 & 1 & 5 & 3 & 1.0 & 1 & 2 & 2 & 1.0 & 4 & 1940 & 0.6 & 350 & & 1 \\
\hline 17 & 54 & 79.6 & 60.2 & 15.3 & 1 & 5 & 3 & 1.5 & 1 & 3 & 2 & 2.0 & 5 & 1986 & 1.0 & 1383 & 1 & 1 \\
\hline 17 & $54 \mathrm{~A}$ & 0.0 & 5.8 & 9.0 & 13 & 5 & & 0.0 & & & & 0.0 & & & 0.0 & & & 1 \\
\hline 17 & 55 & 105.0 & 52.2 & 6.1 & 1 & 5 & 3 & 1.0 & 1 & 2 & 3 & 1.0 & 6 & 1980 & 1.8 & 660 & & 1 \\
\hline 17 & 57 & 0.0 & 0.0 & 4.6 & 7 & 5 & 3 & 0.0 & & 1 & & 0.0 & & 1988 & 12. & & & 1 \\
\hline 17 & 57 & 469.1 & 125.1 & 34.7 & 7 & 5 & 1 & 0.0 & & 2 & & 0.0 & & 1965 & 1.5 & 3350 & 1 & 1 \\
\hline 17 & 57 & 0.0 & 0.0 & 0.0 & 7 & 5 & 1 & 0.0 & & 3 & & 0.0 & & 1966 & 20. & & & 1 \\
\hline 17 & 58 & 126.0 & 72.7 & 32.0 & 1 & 5 & 3 & 1.0 & 1 & 2 & 3 & 1.5 & 6 & 1970 & 1.6 & 740 & 1 & 1 \\
\hline 17 & $58 A$ & 81.5 & 76.9 & 32.7 & 1 & 5 & 3 & 1.5 & 1 & 2 & 5 & 2.0 & 7 & 1969 & 1.3 & 1485 & & 1 \\
\hline 17 & 59 & 96.4 & 46.0 & 3.2 & 1 & 1 & 3 & 1.0 & 1 & 2 & 3 & 2.0 & 7 & 1980 & 1.4 & 531 & & 1 \\
\hline 17 & 60 & 43.1 & 44.6 & 3.1 & 1 & 1 & 3 & 1.0 & 1 & 2 & 3 & 1.0 & 7 & 1989 & 1.0 & & & 1 \\
\hline 17 & 62 & 122.6 & 54.3 & 6.1 & 1 & 1 & 4 & 2.0 & 1 & 2 & 3 & 1.5 & 7 & 1976 & 1.4 & 504 & & 1 \\
\hline 17 & 63 & 51.7 & 52.6 & 5.0 & 1 & 1 & 3 & 1.0 & 1 & 2 & 3 & 1.0 & 6 & 1915 & 0.9 & 489 & 1 & 1 \\
\hline 17 & $63 A$ & 64.0 & 55.6 & 7.0 & 1 & 1 & 3 & 1.0 & 1 & 2 & 1 & 1.0 & 5 & 1975 & 1.0 & 346 & 1 & 1 \\
\hline 17 & $63 B$ & 63.8 & 71.0 & 22.1 & $i$ & 1 & 4 & 2.0 & 1 & 2 & 3 & 2.5 & 7 & 1989 & 1.5 & 389 & $i$ & $i$ \\
\hline 17 & 64 & 0.0 & 63.6 & 23.0 & 80 & 1 & & 0.0 & & & & 0.0 & & & 0.0 & 500 & 1 & 1 \\
\hline 17 & 65 & 30.4 & 29.4 & 0.5 & 1 & 1 & 3 & 1.0 & 1 & 1 & 1 & 1.0 & 3 & 1915 & 0.9 & 100 & & 1 \\
\hline 17 & 66 & 31.9 & 27.9 & 0.5 & 1 & 1 & 3 & 1.0 & 1 & 3 & 2 & 1.0 & 6 & 1920 & 0.8 & 0 & & 1 \\
\hline 17 & 67 & 28.2 & 32.2 & 0.7 & 1 & i & 3 & 1.0 & $i$ & 3 & 2 & 1.0 & 4 & 1916 & 0.7 & 0 & & 1 \\
\hline 17 & 68 & 4.8 & 20.0 & 0.2 & 1 & 1 & 1 & 1.0 & & 1 & 1 & 0.0 & 3 & 1940 & 0.2 & 0 & & 1 \\
\hline 17 & 69 & 5.2 & 20.0 & 0.2 & 1 & 1 & 1 & 1.0 & 0 & 1 & 1 & 0.0 & 1 & 1930 & 0.2 & 0 & & 1 \\
\hline
\end{tabular}




\begin{tabular}{|c|c|c|c|c|c|c|c|c|c|c|c|c|c|c|c|c|c|c|}
\hline Map & Lot & $\begin{array}{l}\text { Bldg. } \\
\text { Value }\end{array}$ & $\begin{array}{l}\text { Land } \\
\text { Value }\end{array}$ & Acres & $\begin{array}{l}\text { Land } \\
\text { Use }\end{array}$ & Zoning & $\begin{array}{l}\text { Bldg. } \\
\text { Grade }\end{array}$ & $\begin{array}{l}\text { \# of } \\
\text { Stories }\end{array}$ & $\begin{array}{l}\text { Occu- } \\
\text { pancy }\end{array}$ & $\begin{array}{l}\text { Heat } \\
\text { Type }\end{array}$ & $\begin{array}{l}\text { \# of } \\
\text { Beds }\end{array}$ & $\begin{array}{l}\text { of } \\
\text { Baths }\end{array}$ & $\begin{array}{l}\text { Total } \\
\text { Rooms }\end{array}$ & $\begin{array}{l}\text { Year } \\
\text { Built }\end{array}$ & $\begin{array}{l}\text { 1st } \\
\text { Floor }\end{array}$ & Frontage & $\begin{array}{l}\text { Wet- } \\
\text { lands }\end{array}$ & $\begin{array}{l}\text { Water- } \\
\text { ahed }\end{array}$ \\
\hline 17 & 70 & 5.4 & 35.3 & 0.8 & 1 & 1 & 1 & 1.0 & 0 & 1 & 1 & 0.0 & 3 & 1940 & 0.2 & 0 & & 1 \\
\hline 17 & 71 & 33.0 & 27.9 & 0.2 & 1 & 1 & 3 & 1.0 & 1 & 2 & 1 & 1.0 & 4 & 1918 & 0.8 & 0 & & 1 \\
\hline 17 & 72 & 29.6 & 15.2 & 0.1 & 1 & 1 & 3 & 1.0 & 1 & 3 & 1 & 1.0 & 3 & 1940 & 0.7 & 0 & & 1 \\
\hline 17 & 73 & 0.0 & 62.5 & 22.0 & 13 & 1 & & 0.0 & & & & 0.0 & & & 0.0 & 0 & & 1 \\
\hline 17 & 75 & 52.4 & 36.7 & 1.0 & 1 & 1 & 3 & 1.0 & 1 & 2 & 2 & 1.0 & 6 & 1954 & 1.3 & 300 & & 1 \\
\hline 17 & 76 & 67.5 & 63.5 & 20.0 & 1 & 1 & 3 & 1.0 & 1 & 2 & 2 & 1.0 & 6 & 1974 & 1.1 & 200 & 1 & 1 \\
\hline 17 & 77 & 0.0 & 32.8 & 1.8 & 13 & 1 & & 0.0 & & & & 0.0 & & & 0.0 & 300 & & 1 \\
\hline 17 & 78 & 0.0 & 67.0 & 29.0 & 80 & 1 & & 0.0 & & & & 0.0 & & & 0.0 & 2125 & 1 & 1 \\
\hline 17 & $78 \mathrm{~A}$ & 0.0 & 44.6 & 5.0 & 13 & 1 & & 0.0 & & & & 0.0 & & & 0.0 & 608 & & 1 \\
\hline 17 & 79 & 112.2 & 64.0 & 13.0 & 1 & 1 & 5 & 1.5 & 1 & 2 & 4 & 2.0 & 7 & 1740 & 1.6 & 685 & 1 & 1 \\
\hline 17 & $79 \mathrm{~A}$ & 107.8 & 52.7 & 5.1 & 1 & $i$ & 3 & 1.0 & 1 & 2 & 3 & 2.0 & 7 & 1971 & 1.9 & & & 1 \\
\hline 17 & 80 & 29.9 & 40.1 & 2.0 & 1 & 1 & 2 & 1.0 & 1 & 3 & 1 & 1.0 & 4 & 1935 & 0.5 & 347 & 1 & 1 \\
\hline 17 & 82 & 10.8 & 74.5 & 32.5 & 5 & 1 & 1 & 0.0 & & 1 & & 0.0 & & 1860 & 1.3 & 975 & & 1 \\
\hline 17 & 83 & 87.6 & 55.8 & 7.1 & 1 & 3 & 3 & 1.0 & 1 & 4 & 3 & 1.0 & 7 & 1980 & 1.6 & 600 & & 1 \\
\hline 17 & 84 & 112.0 & 36.0 & 1.6 & 1 & 3 & 3 & 1.0 & 2 & 2 & 5 & 2.5 & 9 & 1955 & 2.3 & 300 & & 1 \\
\hline 17 & 85 & 95.3 & 53.2 & 5.4 & 1 & 1 & 4 & 1.5 & 1 & 2 & 3 & 2.0 & 5 & 1987 & 1.0 & 350 & & 1 \\
\hline 17 & $85 \mathrm{~A}$ & 54.0 & 51.0 & 4.5 & 1 & 3 & 3 & 1.5 & 1 & 2 & 3 & 1.0 & 7 & 1930 & 0.7 & 300 & & 1 \\
\hline 17 & $85 B$ & 68.7 & 58.1 & 2.3 & 1 & 3 & 3 & 1.5 & $i$ & 3 & 3 & 1.5 & 7 & 1925 & 1.1 & 761 & & 1 \\
\hline 17 & $85 B$ & 82.2 & 0.0 & 0.0 & 6 & 1 & 3 & 0.0 & & 1 & & 0.0 & & 1930 & 2.1 & & & 1 \\
\hline 17 & $85 \mathrm{C}$ & 89.2 & 52.2 & 4.7 & 1 & 1 & 4 & 1.5 & 1 & 2 & 3 & 2.0 & 7 & 1987 & 0.9 & 306 & & 1 \\
\hline 17 & $85 \mathrm{Cl}$ & 0.0 & 44.7 & 5.1 & 13 & 1 & & 0.0 & & & & 0.0 & & & 0.0 & 389 & & 1 \\
\hline 17 & 86 & 118.8 & 71.4 & 25.9 & 1 & 1 & 5 & 2.0 & 1 & 2 & 4 & 2.0 & 9 & 1801 & 1.3 & 753 & & 1 \\
\hline 17 & $86 \mathrm{~A}$ & 0.0 & 52.3 & 10.4 & 13 & $i$ & & 0.0 & & & & 0.0 & & & 0.0 & 291 & & 1 \\
\hline 17 & $86 \mathrm{Al}$ & 0.0 & 70.2 & 35.2 & 13 & 1 & & 0.0 & & & & 0.0 & & & 0.0 & & & 1 \\
\hline 17 & $86 \mathrm{~A} 2$ & 97.8 & 52.7 & 5.1 & 1 & 1 & 4 & 1.5 & 1 & 2 & 3 & 1.5 & 6 & 1984 & 1.3 & 340 & & 1 \\
\hline 17 & $86 \mathrm{~A} 3$ & 134.1 & 62.7 & 12.1 & 1 & 1 & 4 & 1.5 & 1 & 2 & 3 & 3.0 & 8 & 1988 & 1.6 & 314 & & 1 \\
\hline 17 & $86 A 4$ & 178.0 & 63.2 & 14.2 & 1 & $i$ & 4 & 2.0 & 1 & 2 & 3 & 3.0 & 8 & 1986 & 2.0 & 320 & 1 & 1 \\
\hline 17 & $86 A^{5}$ & 132.4 & 52.6 & 5.0 & 1 & 1 & 4 & 2.0 & 2 & 3 & 3 & 3.0 & 8 & 1986 & 1.4 & 320 & & 1 \\
\hline 17 & $86 \mathrm{A6}$ & 93.8 & 59.3 & 9.5 & 1 & 1 & 3 & 1.0 & 1 & 2 & 3 & 2.0 & 5 & 1986 & 1.4 & 318 & 1 & 1 \\
\hline 17 & $86 A 7$ & 0.0 & 51.3 & 9.5 & 13 & 1 & & 0.0 & & & & 0.0 & & & 0.0 & 306 & 1 & 1 \\
\hline 17 & 88 & 0.0 & 72.0 & 38.0 & 13 & 1 & & 0.0 & & & & 0.0 & & & 0.0 & 2400 & & 1 \\
\hline 17 & 89 & 0.0 & 51.4 & 9.5 & 13 & 1 & & 0.0 & & & & 0.0 & & & 0.0 & 300 & & 1 \\
\hline 17 & 90 & 0.0 & 53.2 & 11.0 & 13 & 1 & & 0.0 & & & & 0.0 & & & 0.0 & 600 & & 1 \\
\hline 17 & 92 & 74.2 & 55.7 & 7.1 & 1 & 1 & 3 & 1.0 & 1 & 2 & 3 & 1.0 & 6 & 1955 & 0.9 & 741 & & 1 \\
\hline 17 & 93 & 48.6 & 37.6 & 1.3 & 1 & 1 & 3 & 1.0 & 1 & 4 & 2 & 1.0 & 5 & 1950 & 1.1 & 228 & & 1 \\
\hline 17 & 94 & 0.0 & 117.3 & 130.0 & 13 & 1 & & 0.0 & & & & 0.0 & & & 0.0 & 388 & 1 & 1 \\
\hline 17 & 96 & 124.0 & 56.4 & 7.5 & 1 & 1 & 5 & 1.5 & 1 & 2 & 4 & 1.0 & 8 & 1843 & 1.1 & 372 & 1 & 1 \\
\hline 17 & 97 & 75.7 & 38.3 & 1.6 & $i$ & 1 & 3 & 1.0 & 1 & 2 & 3 & 1.5 & 5 & 1955 & 1.4 & 115 & & 1 \\
\hline 17 & 98 & 0.0 & 27.9 & 1.0 & 80 & 1 & & 0.0 & & & & 0.0 & & & 0.0 & 0 & 1 & 1 \\
\hline 17 & 99 & 54.3 & 37.9 & 1.5 & 1 & 1 & 3 & 1.0 & 1 & 2 & 2 & 1.0 & 4 & 1900 & 0.7 & 355 & 1 & 1 \\
\hline
\end{tabular}




\begin{tabular}{|c|c|c|c|c|c|c|c|c|c|c|c|c|c|c|c|c|c|c|}
\hline Map & Lot & $\begin{array}{l}\text { Bldg. } \\
\text { Value }\end{array}$ & $\begin{array}{l}\text { Land } \\
\text { Value }\end{array}$ & Acres & $\begin{array}{l}\text { Land } \\
\text { Use }\end{array}$ & Zoning & $\begin{array}{l}\text { Bldg. } \\
\text { Grade }\end{array}$ & $\begin{array}{l}\text { of } \\
\text { Stories }\end{array}$ & $\begin{array}{l}\text { Occu- } \\
\text { pancy }\end{array}$ & $\begin{array}{l}\text { Heat } \\
\text { Type }\end{array}$ & $\begin{array}{l}\text { of } \\
\text { Beds }\end{array}$ & $\begin{array}{l}\text { of } \\
\text { Baths }\end{array}$ & $\begin{array}{l}\text { Total } \\
\text { Rooms }\end{array}$ & $\begin{array}{l}\text { Year } \\
\text { Built }\end{array}$ & $\begin{array}{l}\text { 1st } \\
\text { Floor }\end{array}$ & Frontage & $\begin{array}{l}\text { Wet- } \\
\text { lands }\end{array}$ & $\begin{array}{l}\text { Water- } \\
\text { shed }\end{array}$ \\
\hline 17 & 100 & 0.0 & 13.5 & 9.0 & 15 & 1 & & 0.0 & & & & 0.0 & & & 0.0 & & & 1 \\
\hline 18 & 1 & 83.4 & 68.8 & 19.0 & 1 & 1 & 5 & 1.0 & 1 & 2 & 4 & 1.0 & 9 & 1720 & 1.2 & 1300 & 1 & 1 \\
\hline 18 & 2 & 83.5 & 73.1 & 26.1 & 1 & 1 & 4 & 1.5 & 1 & 2 & 2 & 1.5 & 6 & 1987 & 0.9 & 500 & & 1 \\
\hline 18 & $2 \mathrm{~A}$ & 0.0 & 52.8 & 8.8 & 10 & 1 & & 0.0 & & & & 0.0 & & & 0.0 & 0 & & 1 \\
\hline 18 & $2 B$ & 157.6 & 65.4 & 14.0 & 1 & 1 & 6 & 1.5 & 2 & 2 & 5 & 2.5 & 11 & 1790 & 1.6 & 600 & & 1 \\
\hline 18 & 3 & 41.9 & 48.8 & 4.0 & 1 & 1 & 3 & 1.0 & 1 & 2 & 1 & 1.0 & 3 & 1930 & 0.6 & 235 & & 1 \\
\hline 18 & $4 \mathrm{~A}$ & 0.0 & 17.4 & 2.9 & 10 & 1 & & 0.0 & & & & 0.0 & & & 0.0 & 0 & & 1 \\
\hline 18 & $4 B$ & 115.4 & 75.4 & 30.0 & 1 & 1 & 3 & 1.0 & 1 & 4 & 4 & 3.0 & 7 & 1980 & 2.2 & 828 & 1 & 1 \\
\hline 18 & 5 & 80.9 & 103.5 & 83.6 & 1 & $i$ & 5 & 1.0 & & 2 & 3 & 1.0 & 1 & 1800 & 1.8 & 3000 & 1 & 1 \\
\hline 18 & SA & 79.9 & 61.5 & 11.2 & 1 & 1 & 3 & 1.0 & 1 & 4 & 2 & 3.0 & 4 & 1988 & 1.2 & 330 & 1 & 1 \\
\hline 18 & $5 B$ & 0.0 & 51.9 & 10.1 & 13 & 1 & & 0.0 & & & & 0.0 & & & 0.0 & 300 & 1 & 1 \\
\hline 18 & SC & 0.0 & 52.1 & 10.0 & 13 & 1 & & 0.0 & & & & 0.0 & & & 0.0 & 300 & 1 & 1 \\
\hline 18 & 5D & 122.9 & 52.7 & 5.1 & 1 & 1 & 4 & 1.5 & 1 & 2 & 2 & 2.5 & 7 & 1989 & 1.3 & & & 1 \\
\hline 18 & $5 E$ & 0.0 & 44.6 & 5.0 & 13 & 1 & & 0.0 & & & & 0.0 & & & 0.0 & 300 & & 1 \\
\hline 18 & $5 F$ & 0.0 & 52.0 & 10.2 & 13 & 1 & & 0.0 & & & & 0.0 & & & 0.0 & 300 & 1 & 1 \\
\hline 18 & 7 & 0.0 & 50.5 & 10.6 & 13 & 1 & & 0.0 & & & & 0.0 & & & 0.0 & 934 & 1 & 1 \\
\hline 18 & $7 \mathrm{~A}$ & 96.5 & 50.2 & 4.7 & 1 & 1 & 4 & 1.0 & 1 & 2 & 2 & 2.0 & 7 & 1988 & 1.2 & & & 1 \\
\hline 18 & $7 \mathrm{~B}$ & 43.4 & 52.1 & 4.6 & 1 & 1 & 4 & 1.5 & 1 & 2 & 3 & 2.0 & 7 & 1989 & 1.2 & 450 & 1 & 1 \\
\hline 18 & 8 & 106.0 & 51.3 & 5.1 & 1 & 1 & 3 & 1.0 & 1 & 2 & 3 & 2.0 & 8 & 1939 & 1.7 & 1200 & & 1 \\
\hline 18 & 9 & 2.1 & 0.0 & 0.0 & 1 & 1 & 2 & 1.0 & & 2 & 3 & 1.0 & 2 & 1978 & 0.5 & & & 1 \\
\hline 18 & 9 & 71.8 & 96.8 & 64.0 & 9 & $i$ & 5 & 2.0 & & 2 & 3 & 1.0 & 8 & 1800 & 1.0 & 2400 & & 1 \\
\hline 18 & 10 & 290.3 & 57.3 & 8.0 & 78 & 1 & 3 & 0.0 & & 2 & & 0.0 & & 1952 & 13. & 0 & & 1 \\
\hline 18 & 11 & 112.0 & 111.0 & 98.2 & 1 & 1 & 6 & 2.0 & & 2 & 3 & 1.5 & 8 & 1700 & 1.3 & 0 & 1 & 1 \\
\hline 18 & $11 \mathrm{~A}$ & 0.0 & 9.3 & 6.2 & 15 & 1 & & 0.0 & & & & 0.0 & & & 0.0 & 0 & & 1 \\
\hline 18 & $11 \mathrm{~B}$ & 0.0 & 4.6 & 0.8 & 10 & 1 & & 0.0 & & & & 0.0 & & & 0.0 & 0 & & 1 \\
\hline 18 & $11 C$ & 0.0 & 60.2 & 10.0 & 10 & 1 & & 0.0 & & & & 0.0 & & & 0.0 & 0 & 1 & 1 \\
\hline 18 & $11 \mathrm{D}$ & 0.0 & 22.7 & 3.8 & 10 & 1 & & 0.0 & & & & 0.0 & & & 0.0 & 0 & 1 & 1 \\
\hline 18 & 12 & 0.0 & 99.3 & 81.0 & 9 & 1 & & 0.0 & & & & 0.0 & & & 0.0 & 2000 & 1 & $i$ \\
\hline 18 & $12 \mathrm{~A}$ & 73.2 & 52.6 & 5.0 & 1 & 1 & 3 & 1.0 & 1 & 2 & 2 & 1.0 & 4 & 1985 & 1.2 & 350 & 1 & 1 \\
\hline 18 & 13 & 89.6 & 69.4 & 25.0 & 1 & 1 & 3 & 2.0 & $i$ & 2 & 2 & 1.5 & 6 & 1982 & 1.0 & 1860 & & 1 \\
\hline 18 & 14 & 68.5 & 34.6 & 1.0 & 1 & 1 & 3 & 1.0 & 1 & 2 & 3 & 1.5 & 7 & 1952 & 1.0 & 100 & & 1 \\
\hline 18 & 15 & 73.8 & 72.2 & 30.3 & 1 & 1 & 3 & 1.0 & 1 & 2 & 2 & 1.0 & 5 & 1950 & 1.5 & 350 & 1 & 1 \\
\hline 18 & 16 & 97.2 & 58.1 & 10.0 & $i$ & 1 & 3 & 1.0 & 1 & 2 & 3 & 2.0 & 6 & 1979 & 1.1 & 1350 & & 1 \\
\hline 18 & 17 & 0.0 & 45.3 & 5.5 & 13 & 1 & & 0.0 & & & & 0.0 & & & 0.0 & 300 & & 1 \\
\hline 18 & $17 \mathrm{~A}$ & 0.0 & 1.0 & 0.1 & 13 & i & & 0.0 & & & & 0.0 & & & 0.0 & 50 & & 1 \\
\hline 18 & $17 \mathrm{~B}$ & 0.0 & 6.1 & 0.5 & 13 & 1 & & 0.0 & & & & 0.0 & & & 0.0 & 50 & & 1 \\
\hline 18 & 18 & 0.0 & 8.5 & 3.3 & 13 & 1 & & 0.0 & & & & 0.0 & & & 0.0 & 1060 & & 1 \\
\hline 18 & 19 & 78.4 & 52.1 & 4.6 & 1 & 1 & 3 & 1.0 & 1 & 2 & 2 & 1.0 & 5 & 1980 & 1.0 & 1875 & 1 & 1 \\
\hline 18 & $19 \mathrm{~A}$ & 93.6 & 52.1 & 4.6 & 1 & 1 & 3 & 2.0 & 1 & 2 & 4 & 1.5 & 9 & 1980 & 0.5 & 300 & & 1 \\
\hline 18 & $19 \mathrm{~B}$ & 119.4 & 56.0 & 8.6 & 1 & 1 & 5 & 1.0 & 1 & 2 & 3 & 1.0 & 8 & 1809 & 1.6 & 776 & & 1 \\
\hline
\end{tabular}




\begin{tabular}{|c|c|c|c|c|c|c|c|c|c|c|c|c|c|c|c|c|c|c|}
\hline Map & Lot & $\begin{array}{l}\text { Bldg. } \\
\text { Value }\end{array}$ & $\begin{array}{l}\text { Land } \\
\text { Value }\end{array}$ & Acres & $\begin{array}{l}\text { Land } \\
\text { Use }\end{array}$ & Zoning & $\begin{array}{l}\text { Bldg. } \\
\text { Grade }\end{array}$ & $\begin{array}{l}\text { \# of } \\
\text { Stories }\end{array}$ & $\begin{array}{l}\text { Occu- } \\
\text { pancy }\end{array}$ & $\begin{array}{l}\text { Heat } \\
\text { Type }\end{array}$ & $\begin{array}{l}\text { of } \\
\text { Beds }\end{array}$ & $\begin{array}{l}\text { " of } \\
\text { Baths }\end{array}$ & $\begin{array}{l}\text { Total } \\
\text { Rooms }\end{array}$ & $\begin{array}{l}\text { Year } \\
\text { Built }\end{array}$ & $\begin{array}{l}\text { lst } \\
\text { Floor }\end{array}$ & Frontage & $\begin{array}{l}\text { Wet- } \\
\text { lands }\end{array}$ & $\begin{array}{l}\text { Water- } \\
\text { shed }\end{array}$ \\
\hline 18 & $19 \mathrm{C}$ & 93.4 & 50.6 & 5.0 & 1 & 1 & 3 & 2.0 & 1 & 2 & 3 & 1.5 & 7 & 1943 & 0.8 & 325 & 1 & 1 \\
\hline 18 & 19D & 0.0 & 50.2 & 10.3 & 13 & 1 & & 0.0 & & & & 0.0 & & & 0.0 & & & 1 \\
\hline 18 & $19 E$ & 0.0 & 69.2 & 40.0 & 13 & 1 & & 0.0 & & & & 0.0 & & & 0.0 & & & 1 \\
\hline 18 & $19 \mathrm{~F}$ & 0.0 & 48.6 & 58.1 & 13 & 1 & & 0.0 & & & & 0.0 & & & 0.0 & & & 1 \\
\hline 18 & 20 & 68.7 & 95.7 & 78.0 & 1 & 1 & 3 & 1.0 & 1 & 2 & 3 & 1.0 & 5 & 1966 & 1.2 & 2450 & 1 & 1 \\
\hline 18 & 21 & 0.0 & 54.9 & 16.0 & 13 & 1 & & 0.0 & & & & 0.0 & & & 0.0 & 1700 & 1 & 1 \\
\hline 18 & 22 & 0.0 & 3.8 & 1.3 & 13 & 1 & & 0.0 & & & & 0.0 & & & 0.0 & 175 & & 1 \\
\hline 18 & 23 & 136.8 & 100.3 & 78.0 & 1 & 1 & 6 & 2.0 & 1 & 2 & 4 & 2.0 & 8 & 1870 & 1.4 & 3000 & 1 & 1 \\
\hline 18 & 25 & 411.6 & 112.7 & 105.3 & 1 & 1 & 8 & 2.0 & 1 & 2 & 4 & 4.0 & 8 & 1981 & 2.6 & 583 & & 1 \\
\hline 18 & 26 & 118.8 & 38.3 & 2.0 & 1 & 1 & 6 & 1.5 & 1 & 2 & 2 & 1.0 & 6 & 1949 & 1.7 & 583 & & 1 \\
\hline 18 & 27 & 125.1 & 74.1 & 53.0 & 1 & 1 & 5 & 1.0 & 1 & 2 & 5 & 2.0 & 7 & 1941 & 1.9 & 1430 & 1 & 1 \\
\hline 18 & 28 & 70.4 & 41.8 & 3.0 & 1 & 1 & 3 & 1.0 & 1 & 2 & 3 & 2.0 & 6 & 1947 & 1.0 & 309 & & 1 \\
\hline 18 & 29 & 47.0 & 31.0 & 0.8 & 1 & 1 & 3 & 1.5 & 1 & 2 & 2 & 1.0 & 5 & 1950 & 0.7 & 125 & & 1 \\
\hline 18 & 30 & 0.0 & 73.2 & 48.0 & 13 & 1 & & 0.0 & & & & 0.0 & & & 0.0 & 1750 & & 1 \\
\hline 18 & 31 & 0.0 & 90.6 & 78.7 & 13 & 1 & & 0.0 & & & & 0.0 & & & 0.0 & 285 & & 1 \\
\hline 18 & 32 & 69.1 & 43.1 & 3.3 & 1 & 1 & 3 & 1.5 & 1 & 2 & 5 & 1.0 & 6 & 1700 & 1.2 & 585 & 1 & 1 \\
\hline 18 & 33 & 0.0 & 62.0 & 27.0 & 13 & 1 & & 0.0 & & & & 0.0 & & & 0.0 & 486 & 1 & 1 \\
\hline 18 & $33 \mathrm{~A}$ & 0.0 & 7.1 & 5.0 & 15 & 1 & & 0.0 & & & & 0.0 & & & 0.0 & & & 1 \\
\hline 18 & $33 \mathrm{C}$ & 0.0 & 21.4 & 5.2 & 13 & 1 & & 0.0 & & & & 0.0 & & & 0.0 & 300 & & 1 \\
\hline 18 & 33D & 85.0 & 51.5 & 5.6 & 1 & 1 & 3 & 1.5 & 1 & 2 & 3 & 1.5 & 7 & 1987 & 1.1 & 714 & 1 & 1 \\
\hline 18 & 33E & 0.0 & 44.1 & 4.7 & 13 & 1 & & 0.0 & & & & 0.0 & & & 0.0 & 300 & 1 & 1 \\
\hline 18 & $33 F$ & 0.0 & 45.4 & 5.5 & 13 & 1 & & 0.0 & & & & 0.0 & & & 0.0 & 300 & 1 & 1 \\
\hline 18 & $33 G$ & 139.3 & 55.1 & 7.4 & 1 & 1 & 5 & 1.5 & 1 & 2 & 3 & 2.0 & 8 & 1988 & 1.4 & 300 & 1 & 1 \\
\hline 18 & 34 & 48.7 & 31.4 & 0.9 & 1 & 1 & 3 & 1.0 & 1 & 2 & 1 & 1.0 & 5 & 1940 & 0.9 & 147 & & 1 \\
\hline 18 & 35 & 74.6 & 75.7 & 32.0 & 1 & 1 & 4 & 1.0 & 1 & 2 & 3 & 1.0 & 8 & 1775 & 1.4 & 755 & & 1 \\
\hline 18 & 36 & 92.4 & 59.0 & 10.0 & 1 & 1 & 3 & 1.5 & 1 & 2 & 2 & 2.5 & 8 & 1900 & 1.6 & 800 & 1 & 1 \\
\hline 18 & $36 \mathrm{~A}$ & 0.0 & 35.9 & 2.5 & 13 & 1 & & 0.0 & & & & 0.0 & & & 0.0 & 1100 & 1 & 1 \\
\hline 18 & 37 & 0.0 & 27.6 & 30.0 & 13 & 1 & & 0.0 & & & & 0.0 & & & 0.0 & 1235 & 1 & 1 \\
\hline 18 & 38 & 0.0 & 29.2 & 1.0 & 13 & 1 & & 0.0 & & & & 0.0 & & & 0.0 & 400 & & 1 \\
\hline 18 & 39 & 0.0 & 44.1 & 6.0 & 13 & 1 & & 0.0 & & & & 0.0 & & & 0.0 & 525 & & 1 \\
\hline 18 & $39 A$ & 92.0 & 55.5 & 8.2 & 1 & 1 & 3 & 2.0 & 1 & 2 & 4 & 1.0 & 7 & 1950 & 1.4 & 689 & & 1 \\
\hline 18 & $39 \mathrm{~B}$ & 0.0 & 44.6 & 5.0 & 13 & 1 & & 0.0 & & & & 0.0 & & & 0.0 & & & 1 \\
\hline 18 & 40 & 5.1 & 41.8 & 3.0 & 1 & 1 & 3 & 1.0 & 1 & 2 & 2 & 1.0 & 4 & 1962 & 0.5 & 302 & & 1 \\
\hline 18 & 41 & 0.0 & 10.3 & 5.3 & 13 & 1 & & 0.0 & & & & 0.0 & & & 0.0 & 300 & 1 & 1 \\
\hline 18 & $41 \mathrm{~A}$ & 55.5 & 0.0 & 0.0 & 1 & 1 & 3 & 1.5 & 1 & 2 & 3 & 2.0 & 6 & 1950 & 0.8 & & & 1 \\
\hline 18 & $41 \mathrm{~A}$ & 59.6 & 61.1 & 12.0 & 6 & 1 & 3 & 0.0 & & 2 & & 0.0 & & 1950 & 1.1 & 480 & 1 & 1 \\
\hline 18 & $41 B$ & 179.9 & 67.7 & 21.5 & 1 & 1 & 5 & 2.0 & 1 & 2 & 2 & 2.0 & 8 & 1978 & 2.3 & 453 & 1 & 1 \\
\hline 18 & 42 & 0.0 & 112.1 & 125.0 & 13 & 1 & & 0.0 & & & & 0.0 & & & 0.0 & 740 & 1 & 1 \\
\hline 18 & 43 & 0.0 & 56.0 & 13.0 & 13 & 1 & & 0.0 & & & & 0.0 & & & 0.0 & 1350 & 1 & 1 \\
\hline 18 & 44 & 0.0 & 88.7 & 70.0 & 13 & 1 & & 0.0 & & & & 0.0 & & & 0.0 & 300 & & 1 \\
\hline
\end{tabular}




\begin{tabular}{|c|c|c|c|c|c|c|c|c|c|c|c|c|c|c|c|c|c|c|}
\hline Map & Lot & $\begin{array}{l}\text { Bldg. } \\
\text { Value }\end{array}$ & $\begin{array}{l}\text { Land } \\
\text { Value }\end{array}$ & Acres & $\begin{array}{l}\text { Land } \\
\text { Use }\end{array}$ & Zoning & $\begin{array}{l}\text { Bldg. } \\
\text { Grade }\end{array}$ & $\begin{array}{l}\text { "of } \\
\text { Stories }\end{array}$ & $\begin{array}{l}\text { Occu- } \\
\text { pancy }\end{array}$ & $\begin{array}{l}\text { Heat } \\
\text { Type }\end{array}$ & $\begin{array}{l}\text { \# of } \\
\text { Beds }\end{array}$ & $\begin{array}{l}\text { \# of } \\
\text { Baths }\end{array}$ & $\begin{array}{l}\text { Total } \\
\text { Rooms }\end{array}$ & $\begin{array}{l}\text { Year } \\
\text { Built }\end{array}$ & $\begin{array}{l}\text { 1st } \\
\text { Floor }\end{array}$ & Frontage & $\begin{array}{l}\text { Wet- } \\
\text { lands }\end{array}$ & $\begin{array}{l}\text { Water- } \\
\text { shed }\end{array}$ \\
\hline 19 & 1 & 0.0 & 0.0 & 0.0 & 1 & 1 & 2 & 1.0 & 1 & 3 & 3 & 1.0 & 5 & 1910 & 1.1 & & & 1 \\
\hline 19 & 1 & 112.0 & 22.8 & 0.3 & 1 & 1 & 4 & 1.5 & 1 & 2 & 4 & 1.5 & 8 & 1910 & 1.0 & 95 & & 1 \\
\hline 19 & 2 & 72.2 & 29.4 & 0.5 & 1 & 1 & 4 & 1.5 & $i$ & 2 & 5 & 2.0 & 9 & 1850 & 1.1 & 85 & & 1 \\
\hline 19 & 3 & 66.1 & 31.8 & 0.6 & $i$ & 1 & 4 & 1.0 & 1 & 2 & 2 & 1.0 & 4 & 1800 & 1.0 & 120 & & 1 \\
\hline 19 & 4 & 56.5 & 15.6 & 0.2 & 1 & 1 & 4 & 1.0 & $i$ & 2 & 2 & 1.0 & 5 & 1850 & 0.6 & 65 & & 1 \\
\hline 19 & 5 & 68.5 & 34.4 & 0.8 & $i$ & 1 & 4 & 10 & 1 & 2 & 3 & 1.0 & 5 & 1600 & 0.9 & 211 & & 1 \\
\hline 19 & 6 & 122.1 & 37.9 & 1.5 & 72 & 1 & 3 & 0.0 & 0 & 1 & & 0.0 & & 1870 & 1.6 & 245 & & 1 \\
\hline 19 & 7 & 43.2 & 38.9 & 1.7 & 1 & 1 & 3 & 1.0 & 1 & 2 & 2 & 1.0 & 5 & 1800 & 0.6 & 211 & & 1 \\
\hline 19 & 8 & 45.6 & 37.9 & 1.5 & 1 & 1 & 3 & 1.0 & 1 & 2 & 1 & 1.0 & 5 & 1800 & 1.1 & 260 & & $i$ \\
\hline 19 & 9 & 11.6 & 29.4 & 0.4 & 1 & 1 & 3 & 1.0 & $i$ & 3 & 3 & 1.0 & 5 & 1969 & 1.0 & 165 & & 1 \\
\hline 19 & 10 & 70.7 & 43.0 & 2.6 & 1 & 1 & 3 & 2.0 & 1 & 2 & 2 & 1.5 & 5 & 1950 & 0.7 & 200 & & 1 \\
\hline 19 & 11 & 1312 & 52.5 & 4.9 & 1 & 1 & 5 & 20 & 1 & 2 & 3 & 2.5 & 7 & 1988 & 0.9 & 306 & & 1 \\
\hline 19 & $11 \mathrm{~A}$ & 84.7 & 52.1 & 4.7 & 1 & 1 & 3 & 1.0 & $i$ & 2 & 4 & 1.5 & 9 & 1973 & 1.1 & 306 & & 1 \\
\hline 19 & $11 B$ & 0.0 & 0.0 & 0.0 & 1 & 1 & 3 & 1.0 & 1 & 2 & 2 & 1.0 & 4 & 1900 & 0.6 & & & 1 \\
\hline 19 & $11 \mathrm{~B}$ & 127.3 & 53.3 & 5.4 & 1 & 1 & 5 & 1.0 & 1 & 2 & 4 & 1.0 & 9 & 1850 & 1.5 & 814 & & $i$ \\
\hline 19 & 12 & 132.3 & 36.6 & 1.0 & 1 & 1 & 5 & 2.0 & 1 & 2 & 3 & 2.0 & 8 & 1978 & 1.2 & 418 & & 1 \\
\hline 19 & 13 & 44.9 & 44.3 & 3.0 & 1 & $i$ & 2 & 1.0 & 1 & 2 & 2 & 1.0 & 5 & 1940 & 0.8 & 406 & & 1 \\
\hline 19 & $13 \mathrm{~A}$ & 75.6 & 35.3 & 0.8 & 1 & 1 & 3 & 1.0 & 1 & 2 & 4 & 1.5 & 7 & 1970 & 1.0 & 125 & & $i$ \\
\hline 19 & 14 & 71.3 & 37.6 & 1.4 & 1 & 1 & 3 & 1.0 & 1 & 2 & 3 & 1.0 & 6 & 1912 & 1.2 & 200 & & i \\
\hline 19 & 15 & 52.3 & 36.6 & 1.0 & 1 & 1 & 3 & 2.0 & 1 & 2 & 2 & 1.0 & 5 & 1939 & 0.4 & 160 & & 1 \\
\hline 19 & 16 & 65.5 & 72.8 & 27.8 & 1 & 1 & 3 & 1.0 & 1 & 2 & 3 & 1.0 & 6 & 1958 & 1.1 & 2160 & & $i$ \\
\hline 19 & 17 & 63.9 & 32.0 & 0.5 & $i$ & 1 & 3 & 2.0 & 1 & 2 & 4 & 1.5 & 8 & 1930 & 0.9 & 149 & & 1 \\
\hline 19 & 18 & 73.2 & 37.6 & 1.3 & i & 1 & 3 & 1.5 & 1 & 2 & 3 & 1.5 & 8 & 1948 & 0.9 & 350 & & 1 \\
\hline 19 & 19 & 0.0 & 3.9 & 1.5 & 13 & 1 & & 0.0 & & & & 0.0 & & & 0.0 & 534 & & 1 \\
\hline 19 & 20 & 0.0 & 3.7 & 0.2 & 13 & $i$ & & 0.0 & & & & 0.0 & & & 0.0 & 175 & & $i$ \\
\hline 19 & 21 & 51.9 & 45.0 & 3.1 & 1 & 1 & 3 & 1.0 & 1 & 1 & 3 & 1.0 & 5 & 1820 & 1.4 & 575 & & 1 \\
\hline 19 & $21 \mathrm{~A}$ & 100.8 & 52.4 & 4.9 & 1 & 1 & 2 & 1.0 & 1 & 2 & 4 & 2.0 & 9 & 1984 & 1.5 & & & $i$ \\
\hline 19 & $21 B$ & 76.5 & 51.7 & 4.4 & 1 & $i$ & 3 & 1.5 & 1 & 2 & 3 & 1.5 & 6 & 1974 & 1.0 & & & 1 \\
\hline 19 & 22 & 68.4 & 33.9 & 0.8 & 1 & i & 3 & 1.5 & 1 & 2 & 3 & 1.0 & 7 & 1944 & 0.9 & 190 & & $i$ \\
\hline 19 & 23 & 69.2 & 35.3 & 0.8 & 1 & 1 & 3 & 1.0 & 1 & 2 & 3 & 1.0 & 4 & 1966 & 0.8 & 200 & & 1 \\
\hline 19 & 24 & 119.9 & 65.5 & 14.0 & 1 & 1 & 3 & 1.5 & 1 & 2 & 2 & 2.0 & 8 & 1959 & 1.1 & 337 & & 1 \\
\hline 19 & 25 & 0.0 & 46.1 & 6.0 & 13 & 1 & & 0.0 & & & & 0.0 & & & 0.0 & 1230 & & 1 \\
\hline 19 & 26 & 71.8 & 42.5 & 2.5 & 1 & 1 & 3 & 1.0 & 1 & 2 & 3 & 1.0 & 6 & 1953 & 1.0 & 340 & & 1 \\
\hline 19 & 27 & 177.9 & 69.5 & 20.0 & 1 & 1 & 5 & 2.0 & 1 & 2 & 3 & 2.5 & 9 & 1976 & 1.8 & 670 & & $i$ \\
\hline 19 & 28 & 81.4 & 37.9 & 1.5 & 1 & 1 & 4 & 1.0 & 1 & 2 & 4 & 1.5 & 8 & 1850 & 1.4 & 420 & & 1 \\
\hline 19 & 29 & 100.1 & 40.1 & 2.0 & 1 & 1 & 3 & 1.0 & 1 & 2 & 1 & 1.5 & 6 & 1957 & 1.6 & 200 & & 1 \\
\hline 19 & 31 & 94.8 & 52.6 & 5.0 & 1 & 1 & 3 & 2.0 & $i$ & 2 & 3 & 1.5 & 5 & 1981 & 0.9 & 300 & & 1 \\
\hline 19 & $31 \mathrm{~A}$ & 263.2 & 65.7 & 14.2 & 1 & 1 & 5 & 2.0 & 1 & 2 & 3 & 2.5 & 9 & 1770 & 2.9 & 659 & & 1 \\
\hline 19 & $31 E$ & 0.0 & 3.8 & 0.0 & 10 & 1 & & 0.0 & & & & 0.0 & & & 0.0 & & & 1 \\
\hline 19 & 32 & 70.7 & 37.6 & 1.3 & 1 & 1 & 4 & 1.5 & 1 & 2 & 3 & 1.0 & 6 & 1843 & 0.9 & 98 & & 1 \\
\hline
\end{tabular}




\begin{tabular}{|c|c|c|c|c|c|c|c|c|c|c|c|c|c|c|c|c|c|c|}
\hline Map & Lot & $\begin{array}{l}\text { Bldg. } \\
\text { Value }\end{array}$ & $\begin{array}{l}\text { Land } \\
\text { Value }\end{array}$ & Acres & $\begin{array}{l}\text { Land } \\
\text { Use }\end{array}$ & Zoning & $\begin{array}{l}\text { Bldg. } \\
\text { Grade }\end{array}$ & $\begin{array}{l}\text { \# of } \\
\text { Stories }\end{array}$ & $\begin{array}{l}\text { Occu- } \\
\text { pancy }\end{array}$ & $\begin{array}{l}\text { Heat } \\
\text { Type }\end{array}$ & $\begin{array}{l}\text { \# of } \\
\text { Beds }\end{array}$ & $\begin{array}{l}\text { F of } \\
\text { Baths }\end{array}$ & $\begin{array}{l}\text { Total } \\
\text { Rooms }\end{array}$ & $\begin{array}{l}\text { Year } \\
\text { Built }\end{array}$ & $\begin{array}{l}\text { 1st } \\
\text { Floor }\end{array}$ & Frontage & $\begin{array}{l}\text { Wet- } \\
\text { lands }\end{array}$ & $\begin{array}{l}\text { Water- } \\
\text { shed }\end{array}$ \\
\hline 19 & 33 & 9.3 & 54.1 & 6.0 & 80 & 1 & & 0.0 & & & & 0.0 & & & 0.0 & 320 & & 1 \\
\hline 19 & 34 & 45.2 & 36.6 & 1.0 & 1 & 1 & 3 & 1.0 & 1 & 2 & 3 & 1.0 & 7 & 1800 & 0.7 & 220 & & 1 \\
\hline 19 & 35 & 68.3 & 63.0 & 13.0 & 1 & 1 & 4 & 1.5 & 1 & 2 & 2 & 1.0 & 4 & 1780 & 0.9 & 700 & & 1 \\
\hline 19 & 36 & 62.5 & 28.6 & 0.5 & 1 & 1 & 3 & 1.0 & 1 & 2 & 2 & 1.0 & 4 & 1922 & 0.9 & 150 & & 1 \\
\hline 19 & 37 & 80.1 & 64.0 & 13.0 & 1 & 1 & 3 & 1.0 & 1 & 2 & 5 & 1.0 & 9 & 1930 & 0.9 & 103 & & 1 \\
\hline 19 & 38 & 52.4 & 40.8 & 2.1 & 1 & 1 & 3 & 1.0 & 1 & 2 & 3 & 1.0 & 8 & 1939 & 1.0 & 610 & & 1 \\
\hline 19 & 39 & 58.4 & 33.7 & 0.8 & 1 & 1 & 3 & 1.5 & 1 & 2 & 3 & 1.5 & 5 & 1940 & 1.1 & 115 & & 1 \\
\hline 19 & 40 & 62.5 & 37.9 & 1.5 & 1 & 1 & 4 & 1.0 & 1 & 2 & 1 & 1.0 & 6 & 1880 & 0.8 & 315 & & 1 \\
\hline 19 & 41 & 76.8 & 40.4 & 2.1 & 1 & 1 & 4 & 1.0 & 1 & 2 & 2 & 1.5 & 6 & 1969 & 1.0 & 233 & & 1 \\
\hline 19 & 42 & 0.0 & 59.1 & 2.0 & 13 & 1 & & 0.0 & & & & 0.0 & & & 0.0 & 0 & & 1 \\
\hline 20 & CEMI & 0.0 & 55.3 & 6.8 & 70 & 1 & & 0.0 & & & & 0.0 & & & 0.0 & & & 1 \\
\hline 20 & CEM2 & 2.0 & 34.5 & 0.8 & 70 & 1 & & 0.0 & & & & 0.0 & & & 0.0 & & & 1 \\
\hline 20 & CEM3 & 0.0 & 32.8 & 0.6 & 70 & 1 & & 0.0 & & & & 0.0 & & & 0.0 & & & 1 \\
\hline 20 & 2 & 75.1 & 19.9 & 0.2 & 78 & 1 & 2 & 0.0 & 0 & 2 & & 0.0 & & 1953 & 2.0 & 75 & & 1 \\
\hline 20 & 3 & 68.2 & 20.0 & 0.2 & 1 & 1 & 4 & 1.0 & 1 & 2 & 3 & 1.5 & 7 & 1800 & 0.8 & 280 & & 1 \\
\hline 20 & 4 & 112.6 & 19.2 & 0.3 & 76 & 1 & 3 & 0.0 & & 2 & & 0.0 & & 1875 & 2.0 & 160 & & 1 \\
\hline 20 & 5 & 280.5 & 117.4 & 19.0 & 78 & 1 & 3 & 0.0 & & 2 & & 0.0 & & 1875 & 1.3 & 570 & & 1 \\
\hline 20 & 5 & 0.0 & 0.0 & 0.0 & 78 & 1 & 3 & 0.0 & & 2 & & 0.0 & & 1796 & 1.7 & & & 1 \\
\hline 20 & 6 & 64.1 & 47.3 & 3.5 & 1 & 1 & 3 & 2.0 & 1 & 4 & 3 & 2.0 & 7 & 1967 & 0.6 & 300 & & 1 \\
\hline 20 & 7 & 131.7 & 44.4 & 3.0 & 1 & 1 & 4 & 2.0 & 1 & 2 & 3 & 2.0 & 7 & 1987 & 1.4 & 297 & & 1 \\
\hline 20 & 8 & 63.0 & 22.7 & 0.2 & 78 & 1 & 2 & 0.0 & & 2 & & 0.0 & & 1919 & 1.1 & 290 & & 1 \\
\hline 20 & 9 & 0.0 & 57.4 & 14.0 & 13 & 1 & & 0.0 & & & & 0.0 & & & 0.0 & 1010 & & 1 \\
\hline 20 & 10 & 0.0 & 1.2 & 0.1 & 78 & 1 & & 0.0 & & & & 0.0 & & & 0.0 & 44 & & 1 \\
\hline 20 & 12 & 62.3 & 36.9 & 1.1 & 1 & 1 & 3 & 1.0 & 1 & 2 & 2 & 1.0 & 5 & 1964 & 1.1 & 140 & & 1 \\
\hline 20 & $13 \mathrm{~A}$ & 0.0 & 24.4 & 14.8 & 13 & 1 & & 0.0 & & & & 0.0 & & & 0.0 & 413 & & 1 \\
\hline 20 & $13 B$ & 0.0 & 44.1 & 4.6 & 13 & 1 & & 0.0 & & & & 0.0 & & & 0.0 & & & $i$ \\
\hline 20 & 14 & 222.6 & 36.8 & 0.5 & 72 & 1 & 1 & 0.0 & & 2 & & 0.0 & & 1882 & 3.2 & 211 & & 1 \\
\hline 20 & 15 & 147.5 & 33.0 & 0.8 & 1 & 1 & 5 & 2.0 & 1 & 2 & 3 & 1.5 & 10 & 1830 & 2.4 & 811 & & 1 \\
\hline 20 & 16 & 69.9 & 41.8 & 2.4 & 1 & 1 & 4 & 1.5 & 1 & 2 & 3 & 2.0 & 8 & 1900 & 1.1 & 463 & & 1 \\
\hline 20 & 17 & 88.5 & 61.8 & 21.8 & 1 & 1 & 4 & 1.5 & 1 & 2 & 2 & 2.0 & 8 & 1969 & 1.2 & 220 & & 1 \\
\hline 20 & 18 & 0.4 & 49.1 & 8.0 & 13 & 1 & & 0.0 & & & & 0.0 & & & 0.0 & 1180 & & 1 \\
\hline 20 & 19 & 0.0 & 61.5 & 27.0 & 13 & 1 & & 0.0 & & & & 0.0 & & & 0.0 & 960 & 1 & 1 \\
\hline 20 & $19 \mathrm{~A}$ & 121.5 & 52.3 & 4.8 & 1 & 1 & 4 & 2.0 & 1 & 2 & 4 & 1.5 & 8 & 1965 & 1.2 & & & 1 \\
\hline 20 & 20 & 0.0 & 70.5 & 45.0 & 15 & 1 & & 0.0 & & & & 0.0 & & & 0.0 & 515 & & 1 \\
\hline 20 & 21 & 0.0 & 31.1 & 1.0 & 13 & 1 & & 0.0 & & & & 0.0 & & & 0.0 & 264 & & 1 \\
\hline 20 & 22 & 59.6 & 36.6 & 1.0 & 1 & 1 & 3 & 1.0 & 1 & 2 & 2 & 1.0 & 4 & 1951 & 1.1 & 190 & & 1 \\
\hline 20 & 23 & 80.1 & 41.8 & 2.4 & 1 & 1 & 3 & 2.0 & 1 & 2 & 3 & 1.5 & 7 & 1906 & 0.9 & 443 & & 1 \\
\hline 20 & 24 & 68.1 & 32.2 & 0.7 & 1 & 1 & 3 & 1.5 & 1 & 2 & 3 & 1.0 & 7 & 1806 & 1.1 & 131 & & 1 \\
\hline 20 & 25 & 52.5 & 31.1 & 0.6 & 1 & 1 & 4 & 1.5 & 1 & 2 & 3 & 1.0 & 6 & 1900 & 0.5 & 150 & & 1 \\
\hline 20 & 26 & 72.2 & 20.4 & 0.2 & $i$ & 1 & 3 & 1.5 & 1 & 2 & 3 & 2.0 & 9 & 1930 & 1.4 & 65 & & 1 \\
\hline
\end{tabular}




\begin{tabular}{|c|c|c|c|c|c|c|c|c|c|c|c|c|c|c|c|c|c|c|}
\hline Map & Lot & $\begin{array}{l}\text { Bldg. } \\
\text { Value }\end{array}$ & $\begin{array}{l}\text { Land } \\
\text { Value }\end{array}$ & Acres & $\begin{array}{l}\text { Land } \\
\text { Use }\end{array}$ & Zoning & $\begin{array}{l}\text { Bldg. } \\
\text { Grade }\end{array}$ & $\begin{array}{l}\text { \# of } \\
\text { Stories }\end{array}$ & $\begin{array}{l}\text { Occu- } \\
\text { pancy }\end{array}$ & $\begin{array}{l}\text { Heat } \\
\text { Type }\end{array}$ & $\begin{array}{l}\text { \# of } \\
\text { Beds }\end{array}$ & $\begin{array}{l}\text { \# of } \\
\text { Baths }\end{array}$ & $\begin{array}{l}\text { Total } \\
\text { Rooms }\end{array}$ & $\begin{array}{l}\text { Year } \\
\text { Built }\end{array}$ & $\begin{array}{l}\text { 1st } \\
\text { Floor }\end{array}$ & Frontage & $\begin{array}{l}\text { Wet- } \\
\text { lands }\end{array}$ & $\begin{array}{l}\text { Water- } \\
\text { shed }\end{array}$ \\
\hline 20 & 27 & 0.0 & 28.1 & 0.8 & 13 & 1 & & 0.0 & & & & 0.0 & & & 0.0 & 105 & & 1 \\
\hline 20 & 28 & 64.1 & 62.6 & 11.9 & 1 & 1 & 3 & 1.0 & 1 & 2 & 2 & 1.0 & 5 & 1934 & 1.0 & 300 & & 1 \\
\hline 20 & 29 & 59.8 & 33.9 & 0.7 & 1 & 1 & 3 & 1.5 & 1 & 2 & 3 & 1.0 & 6 & 1850 & 1.1 & 390 & & 1 \\
\hline 20 & 30 & 94.3 & 37.9 & 1.4 & 1 & 1 & 4 & 1.5 & 1 & 2 & 3 & 2.0 & 6 & 1989 & 0.9 & 230 & & 1 \\
\hline 20 & 31 & 67.0 & 34.5 & 0.8 & 1 & 1 & 3 & 1.0 & 1 & 2 & 4 & 1.0 & 6 & 1963 & 0.9 & 150 & & 1 \\
\hline 20 & 32 & 0.0 & 30.9 & 1.0 & 13 & 1 & & 0.0 & & & & 0.0 & & & 0.0 & 175 & & 1 \\
\hline 20 & 33 & 64.4 & 37.6 & 1.3 & 1 & 1 & 3 & 1.0 & 1 & 2 & 3 & 1.0 & 5 & 1979 & 1.0 & 185 & & 1 \\
\hline 20 & 34 & 0.0 & 30.9 & 1.0 & 13 & 1 & & 0.0 & & & & 0.0 & & & 0.0 & 175 & & 1 \\
\hline 20 & 35 & 84.3 & 39.0 & 1.8 & 1 & 1 & 3 & 1.0 & 1 & 2 & 3 & 2.0 & 7 & 1964 & 1.3 & 225 & & 1 \\
\hline 20 & 37 & 87.2 & 69.5 & 20.0 & 1 & 1 & 4 & 1.0 & 1 & 2 & 4 & 2.0 & 7 & 1782 & 1.3 & 1283 & 1 & 1 \\
\hline 20 & $37 \mathrm{~A}$ & 78.6 & 54.8 & 7.3 & 1 & 1 & 3 & 2.0 & 1 & 2 & 4 & 1.5 & 7 & 1972 & 0.8 & 300 & & 1 \\
\hline 20 & $37 \mathrm{C}$ & 92.3 & 67.3 & 16.0 & 1 & 1 & 3 & 2.0 & 1 & 2 & 3 & 2.0 & 7 & 1978 & 0.9 & 300 & 1 & 1 \\
\hline 20 & 37D & 63.4 & 52.6 & 5.0 & 1 & 1 & 3 & 1.0 & 1 & 2 & 2 & 1.0 & 6 & 1974 & 0.8 & & & 1 \\
\hline 20 & 38 & 49.8 & 44.4 & 3.0 & 1 & 1 & 3 & 2.0 & 1 & 2 & 1 & 1.0 & 4 & 1936 & 0.6 & 447 & & 1 \\
\hline 20 & 39 & 83.2 & 46.7 & 3.4 & 2 & 1 & 3 & 1.0 & 2 & 2 & 5 & 2.0 & 10 & 1960 & 1.3 & 110 & & 1 \\
\hline 20 & 40 & 74.6 & 40.1 & 2.0 & 1 & 1 & 3 & 1.0 & 1 & 2 & 3 & 1.5 & 6 & 1960 & 1.5 & 200 & & 1 \\
\hline 20 & 41 & 16.7 & 18.6 & 0.3 & 1 & 1 & 1 & 1.0 & 1 & 2 & 2 & 1.0 & 8 & 1900 & 0.7 & 85 & & 1 \\
\hline 20 & 42 & 55.8 & 26.3 & 0.2 & 1 & 1 & 3 & 1.0 & 1 & 2 & 4 & 1.0 & 6 & 1930 & 1.2 & 176 & & 1 \\
\hline 20 & 43 & 16.7 & 22.7 & 0.3 & 1 & 1 & 3 & 1.0 & 1 & 1 & 1 & 0.5 & 3 & 1930 & 0.5 & 110 & & 1 \\
\hline 20 & $43 \mathrm{~A}$ & 52.8 & 42.0 & 2.4 & 1 & 1 & 4 & 1.5 & 1 & 2 & 2 & 1.0 & 5 & 1925 & 0.7 & 680 & & 1 \\
\hline 20 & 45 & 0.0 & 3.1 & 0.5 & 13 & 3 & & 0.0 & & & & 0.0 & & & 0.0 & 616 & & 1 \\
\hline 20 & 46 & 112.4 & 20.5 & 0.2 & 4 & 3 & 3 & 0.0 & & 2 & & 0.0 & & 1900 & 2.4 & 540 & & 1 \\
\hline 20 & 47 & 53.9 & 42.5 & 2.5 & 1 & 1 & 3 & 1.0 & 1 & 2 & 3 & 1.0 & 5 & 1950 & 1.0 & 355 & & 1 \\
\hline 20 & 48 & 70.8 & 44.4 & 3.0 & 1 & 1 & 3 & 1.0 & 1 & 2 & 3 & 1.0 & 10 & 1910 & 1.2 & 390 & & 1 \\
\hline 20 & 49 & 84.3 & 47.3 & 3.5 & 1 & 1 & 3 & 1.0 & 1 & 2 & 3 & 1.0 & 6 & 1969 & 1.6 & 257 & & 1 \\
\hline 20 & 50 & 0.0 & 1.6 & 1.0 & 15 & 1 & & 0.0 & & & & 0.0 & & & 0.0 & 0 & & 1 \\
\hline 20 & 51 & 79.5 & 28.4 & 0.3 & 6 & 1 & 3 & 0.0 & & 2 & & 0.0 & & 1960 & 1.8 & 80 & & 1 \\
\hline 21 & $1 \mathrm{~A}$ & 0.0 & 44.1 & 4.7 & 13 & 1 & & 0.0 & & & & 0.0 & & & 0.0 & 300 & & 1 \\
\hline 21 & 2 & 50.7 & 20.0 & 0.3 & 1 & 1 & 3 & 2.0 & 1 & 2 & 3 & 1.0 & 6 & 1900 & 0.6 & 370 & 1 & 1 \\
\hline 21 & 3 & 71.7 & 53.4 & 5.5 & 1 & 1 & 3 & 1.5 & 1 & 2 & 4 & 1.0 & 7 & 1944 & 0.8 & 510 & 1 & 1 \\
\hline 21 & 4 & 56.5 & 47.3 & 3.5 & 1 & 1 & 3 & 1.0 & 1 & 2 & 3 & 1.0 & 6 & 1966 & 1.0 & 192 & 1 & 1 \\
\hline 21 & 5 & 120.6 & 51.0 & 4.5 & 1 & 1 & 5 & 2.0 & 1 & 2 & 4 & 2.0 & 6 & 1850 & 1.0 & 850 & 1 & 1 \\
\hline 21 & 6 & 90.8 & 56.1 & 7.4 & 1 & 1 & 4 & 2.0 & 1 & 2 & 4 & 1.0 & 8 & 1790 & 1.3 & 548 & & 1 \\
\hline 21 & 7 & 58.4 & 38.3 & 1.6 & 1 & 1 & 3 & 2.0 & 1 & 2 & 3 & 1.0 & 7 & 1900 & 0.6 & 235 & & 1 \\
\hline 21 & 8 & 74.8 & 37.1 & 1.2 & 1 & 1 & 3 & 1.0 & 1 & 2 & 3 & 2.0 & 7 & 1950 & 1.2 & 257 & & 1 \\
\hline 21 & 9 & 62.0 & 47.3 & 3.5 & 1 & 1 & 3 & 2.0 & 1 & 2 & 3 & 1.0 & 7 & 1935 & 0.9 & 0 & & 1 \\
\hline 21 & 10 & 114.8 & 47.4 & 3.8 & 2 & 1 & 5 & 2.0 & 1 & 2 & 5 & 2.0 & 10 & 1880 & 1.6 & 620 & & 1 \\
\hline 21 & 11 & 0.0 & 250.4 & 23.9 & 10 & 1 & & 0.0 & & & & 0.0 & & & 0.0 & 525 & 1 & 1 \\
\hline 21 & 12 & 105.3 & 36.6 & 1.0 & 1 & 1 & 5 & 1.0 & 1 & 2 & 4 & 1.5 & 10 & 1720 & 1.7 & 570 & & 1 \\
\hline 21 & 13 & 99.0 & 28.6 & 0.5 & 1 & 1 & 5 & 2.0 & 1 & 2 & 4 & 1.5 & 8 & 1800 & 1.2 & 100 & & 1 \\
\hline
\end{tabular}




\begin{tabular}{|c|c|c|c|c|c|c|c|c|c|c|c|c|c|c|c|c|c|c|}
\hline Map & Lot & $\begin{array}{l}\text { Bldg. } \\
\text { Value }\end{array}$ & $\begin{array}{l}\text { Land } \\
\text { Value }\end{array}$ & Acres & $\begin{array}{l}\text { Land } \\
\text { Use }\end{array}$ & Zoning & $\begin{array}{l}\text { Bldg. } \\
\text { Grade }\end{array}$ & $\begin{array}{l}\text { of } \\
\text { Stories }\end{array}$ & $\begin{array}{l}\text { Occu- } \\
\text { pancy }\end{array}$ & $\begin{array}{l}\text { Heat } \\
\text { Type }\end{array}$ & $\begin{array}{l}\text { of } \\
\text { Beds }\end{array}$ & $\begin{array}{l}\text { of } \\
\text { Baths }\end{array}$ & $\begin{array}{l}\text { Total } \\
\text { Rooms }\end{array}$ & $\begin{array}{l}\text { Year } \\
\text { Built }\end{array}$ & $\begin{array}{l}\text { 1st } \\
\text { Floor }\end{array}$ & Frontage & $\begin{array}{l}\text { Wet- } \\
\text { lands }\end{array}$ & $\begin{array}{l}\text { Water } \\
\text { shed }\end{array}$ \\
\hline 21 & 14 & 66.7 & 29.3 & 0.4 & 6 & 1 & 2 & 0.0 & & 2 & & 0.0 & & 1924 & 2.5 & 125 & & 1 \\
\hline 21 & 15 & 72.5 & 20.0 & 0.3 & 1 & $i$ & 3 & 2.0 & 1 & 2 & 5 & 2.0 & 8 & 1928 & 1.6 & 150 & & 1 \\
\hline 21 & 16 & 65.6 & 36.6 & 1.0 & 1 & 1 & 3 & 1.0 & 1 & 2 & 3 & 1.0 & 8 & 1813 & 1.3 & 180 & & 1 \\
\hline 21 & 17 & 11.7 & 52.6 & 5.0 & 1 & $i$ & & 0.0 & & & & 0.0 & & & 0.0 & 490 & & $i$ \\
\hline 21 & 18 & 67.7 & 45.3 & 3.3 & 1 & 1 & 3 & 1.0 & 1 & 2 & 1 & 1.0 & 5 & 1870 & 1.3 & 330 & 1 & 1 \\
\hline 21 & 19 & 70.6 & 51.0 & 4.5 & 1 & 1 & 3 & 1.5 & 1 & 2 & 1 & 4.0 & 7 & 1920 & 0.8 & 740 & 1 & 1 \\
\hline 21 & $19 \mathrm{~A}$ & 91.1 & 39.6 & 3.5 & 1 & 1 & 3 & 1.0 & $i$ & 2 & $i$ & 2.0 & 6 & 1970 & 1.2 & 672 & $i$ & 1 \\
\hline 21 & 20 & 78.0 & 52.1 & 4.6 & 1 & 1 & 5 & 1.0 & 1 & 4 & 4 & 1.0 & 8 & 1823 & 1.3 & 859 & & 1 \\
\hline 21 & 21 & 127.9 & 55.3 & 7.5 & 1 & 1 & 5 & 2.0 & 1 & 2 & 5 & 2.0 & 12 & 1823 & 1.4 & 1980 & & 1 \\
\hline 21 & 22 & 60.1 & 40.1 & 2.0 & 1 & 1 & 3 & 1.0 & 1 & 2 & 3 & 1.0 & 6 & 1930 & 0.8 & 830 & & 1 \\
\hline 21 & 23 & 85.2 & 41.1 & 2.3 & 1 & 1 & 3 & 1.0 & $i$ & 2 & 3 & 2.0 & 6 & 1962 & 1.3 & 600 & & 1 \\
\hline 21 & 25 & 69.8 & 33.0 & 0.7 & 1 & 3 & 3 & 2.0 & $i$ & 2 & 4 & 1.5 & 8 & 1920 & 0.7 & 422 & & 1 \\
\hline 21 & 26 & 68.0 & 50.0 & 0.4 & 6 & 3 & 2 & 0.0 & & 2 & & 0.0 & & 1920 & 2.5 & 175 & & 1 \\
\hline 21 & 27 & 31.8 & 17.0 & 0.2 & 1 & 3 & 2 & 1.0 & 1 & 2 & 1 & 1.0 & 5 & 1940 & 1.0 & 152 & & 1 \\
\hline 21 & 28 & 37.3 & 9.5 & 0.4 & 1 & 3 & 2 & 1.0 & 1 & 2 & 2 & 1.0 & 6 & 1915 & 0.9 & 200 & & 1 \\
\hline 21 & 28 & 53.6 & 19.0 & 0.4 & 5 & 3 & 3 & 0.0 & & 2 & & 0.0 & & 1959 & 2.4 & & & 1 \\
\hline 21 & 29 & 0.8 & 56.2 & 3.0 & 5 & 3 & & 0.0 & & & & 0.0 & & & 0.0 & 1270 & 1 & 1 \\
\hline 21 & 30 & 0.0 & 6.5 & 1.5 & 15 & 1 & & 0.0 & & & & 0.0 & & & 0.0 & 771 & 1 & 1 \\
\hline 21 & 31 & 0.0 & 53.6 & 21.5 & 13 & 1 & & 0.0 & & & & 0.0 & & & 0.0 & 1228 & $i$ & $i$ \\
\hline 21 & 32 & 86.1 & 48.3 & 8.0 & 1 & 1 & 3 & 1.0 & 1 & 4 & 3 & 2.0 & 6 & 1967 & 1.4 & 350 & & 1 \\
\hline 21 & 33 & 221.0 & 79.1 & 15.1 & 6 & 1 & 4 & 0.0 & & 2 & & 0.0 & & 1965 & 2.6 & & & 1 \\
\hline 21 & 35 & 0.0 & 38.3 & 4.8 & 13 & 1 & & 0.0 & & & & 0.0 & & & 0.0 & 851 & & $i$ \\
\hline 21 & $35 \mathrm{~A}$ & 90.7 & 52.1 & 10.0 & 1 & 1 & 4 & 1.0 & 1 & 4 & 3 & 1.0 & 6 & 1974 & 1.5 & 300 & & 1 \\
\hline 21 & $35 \mathrm{~B}$ & 74.5 & 49.8 & 8.4 & 1 & 1 & 3 & 1.0 & 1 & 4 & 3 & 1.0 & 5 & 1973 & 1.2 & 300 & & $i$ \\
\hline 21 & 36 & 56.9 & 38.9 & 1.8 & 1 & 1 & 3 & 1.0 & $i$ & 2 & 3 & 1.0 & 6 & 1930 & 1.1 & 214 & & $i$ \\
\hline 21 & $36 A$ & 67.0 & 52.3 & 4.8 & 1 & 1 & 3 & 1.0 & 1 & 2 & 3 & 1.0 & 5 & 1973 & 1.1 & 348 & & 1 \\
\hline 22 & CEM & 0.0 & 38.5 & 1.7 & 70 & 1 & & 0.0 & & & & 0.0 & & & 0.0 & 0 & & 1 \\
\hline 22 & 1 & 49.9 & 42.5 & 2.5 & 1 & 1 & 2 & 1.0 & 1 & 2 & 2 & 1.0 & 5 & 1880 & 1.1 & 0 & & i \\
\hline 22 & IB & 42.9 & 56.6 & 7.7 & 1 & 1 & 3 & 1.0 & $i$ & 2 & 2 & 1.0 & 4 & 1910 & 0.9 & 670 & 1 & 1 \\
\hline 22 & 2 & 54.2 & 43.1 & 2.8 & 1 & 1 & 2 & 1.0 & 2 & 2 & 3 & 2.0 & 8 & 1900 & 1.3 & 0 & & $i$ \\
\hline 22 & 3 & 82.8 & 33.1 & 0.7 & 1 & 1 & 3 & 1.0 & 1 & 2 & 3 & 1.0 & 7 & 1940 & 1.3 & 0 & & i \\
\hline 22 & 4 & 56.1 & 15.9 & 0.3 & 78 & $i$ & 2 & 0.0 & & 1 & & 0.0 & & 1928 & 2.0 & 40 & & i \\
\hline 22 & 5 & 0.0 & 0.0 & 0.0 & 2 & 1 & 3 & 1.5 & 1 & 3 & 4 & 2.0 & 10 & 1843 & 1.0 & & & 1 \\
\hline 22 & 5 & 139.6 & 29.5 & 0.5 & 2 & 1 & 5 & 2.0 & 1 & 2 & 3 & 1.0 & 6 & 1853 & 0.8 & 160 & & $i$ \\
\hline 22 & 6 & 87.4 & 51.0 & 4.5 & 1 & 1 & 3 & 1.5 & 1 & 2 & 4 & 2.0 & 8 & 1900 & 0.9 & 280 & & i \\
\hline 22 & 7 & 58.2 & 23.0 & 0.3 & 72 & 1 & 1 & 0.0 & & 1 & & 0.0 & & 1875 & 1.2 & 110 & & 1 \\
\hline 22 & 8 & 64.5 & 35.3 & 0.8 & 1 & 1 & 3 & 1.0 & 1 & 2 & 2 & 1.0 & 5 & 1960 & 0.9 & 100 & & $i$ \\
\hline 22 & $8 A$ & 0.0 & 1.9 & 1.5 & 13 & 1 & & 0.0 & & & & 0.0 & & & 0.0 & 300 & 1 & 1 \\
\hline 22 & 9 & 72.3 & 60.0 & 9.9 & 1 & 1 & 3 & 1.0 & 1 & 2 & 2 & 1.0 & 7 & 1931 & 0.9 & 240 & & 1 \\
\hline 22 & 9 & 0.0 & 0.0 & 0.0 & 1 & 1 & 3 & 1.0 & 1 & 2 & 2 & 1.0 & 4 & 1955 & 0.7 & & & 1 \\
\hline
\end{tabular}




\begin{tabular}{|c|c|c|c|c|c|c|c|c|c|c|c|c|c|c|c|c|c|c|}
\hline Map & Lot & $\begin{array}{l}\text { Bldg. } \\
\text { Value }\end{array}$ & $\begin{array}{l}\text { Land } \\
\text { Value }\end{array}$ & Acres & $\begin{array}{l}\text { Land } \\
\text { Use }\end{array}$ & Zoning & $\begin{array}{l}\text { Bldg. } \\
\text { Grade }\end{array}$ & $\begin{array}{l}\text { " of } \\
\text { Stories }\end{array}$ & $\begin{array}{l}\text { Occu- } \\
\text { pancy }\end{array}$ & $\begin{array}{l}\text { Heat } \\
\text { Type }\end{array}$ & $\begin{array}{l}\text { \# of } \\
\text { Beds }\end{array}$ & $\begin{array}{l}\text { \# of } \\
\text { Baths }\end{array}$ & $\begin{array}{l}\text { Total } \\
\text { Rooms }\end{array}$ & $\begin{array}{l}\text { Year } \\
\text { Built }\end{array}$ & $\begin{array}{l}\text { 1 st } \\
\text { Floor }\end{array}$ & Frontage & $\begin{array}{l}\text { Wet- } \\
\text { lands }\end{array}$ & $\begin{array}{l}\text { Water } \\
\text { shed }\end{array}$ \\
\hline 22 & $9 A$ & 0.0 & 0.9 & 0.2 & 10 & 1 & & 0.0 & & & & 0.0 & & & 0.0 & & & 1 \\
\hline 22 & 10 & 81.9 & 35.3 & 0.9 & 1 & 1 & 3 & 1.0 & 1 & 2 & 3 & 1.0 & 7 & 1963 & 1.5 & 160 & 1 & 1 \\
\hline 22 & 11 & 76.4 & 47.6 & 7.0 & 1 & 1 & 3 & 1.0 & 1 & 2 & 4 & 1.0 & 9 & 1820 & 1.8 & 420 & 1 & 1 \\
\hline 22 & $11 \mathrm{~A}$ & 70.4 & 44.2 & 4.8 & 1 & 1 & 3 & 1.0 & 1 & 2 & 2 & 1.0 & 5 & 1970 & 0.9 & 318 & 1 & 1 \\
\hline 22 & 12 & 0.0 & 45.9 & 7.7 & 10 & 1 & & 0.0 & & & & 0.0 & & & 0.0 & 520 & & 1 \\
\hline 22 & 13 & 64.9 & 30.9 & 1.0 & 1 & 1 & 3 & 1.5 & 1 & 2 & 3 & 2.0 & 6 & 1800 & 0.8 & 200 & & 1 \\
\hline 22 & 15 & 38.0 & 43.1 & 4.5 & 1 & 1 & 2 & 1.0 & 1 & 3 & 3 & 1.0 & 7 & 1800 & 1.1 & 400 & & 1 \\
\hline 22 & 16 & 97.3 & 35.3 & 2.3 & 1 & 1 & 4 & 2.0 & 1 & 2 & 3 & 2.0 & 6 & 1989 & 1.2 & 115 & & 1 \\
\hline 22 & 17 & 70.8 & 28.2 & 0.6 & 1 & 1 & 3 & 1.0 & 1 & 2 & 3 & 2.0 & 6 & 1800 & 1.3 & 134 & & 1 \\
\hline 22 & 18 & 61.7 & 37.9 & 3.0 & 1 & 1 & 3 & 1.0 & 1 & 2 & 3 & 1.0 & 6 & 1940 & 1.0 & 195 & & 1 \\
\hline 22 & 19 & 0.0 & 42.4 & 7.5 & 13 & 1 & & 0.0 & & & & 0.0 & & & 0.0 & 652 & & 1 \\
\hline 22 & 20 & 73.8 & 35.9 & 2.5 & 1 & 1 & 3 & 1.0 & 1 & 2 & 3 & 1.0 & 6 & 1797 & 1.5 & 700 & & 1 \\
\hline 22 & $21 \mathrm{~A}$ & 0.0 & 3.8 & 3.0 & 15 & 1 & & 0.0 & & & & 0.0 & & & 0.0 & 475 & & 1 \\
\hline 22 & 22 & 79.7 & 42.5 & 3.9 & 1 & 1 & 3 & 1.0 & 1 & 2 & 3 & 2.0 & 7 & 1970 & 1.1 & 282 & & 1 \\
\hline 22 & 23 & 68.6 & 28.6 & 0.7 & 1 & 1 & 3 & 1.5 & 1 & 2 & 2 & 1.5 & 5 & 1939 & 1.0 & 194 & & 1 \\
\hline 22 & 24 & 47.4 & 26.1 & 0.5 & 1 & 1 & 3 & 1.0 & 1 & 2 & 2 & 1.0 & 4 & 1940 & 0.6 & 240 & & 1 \\
\hline 22 & 25 & 89.8 & 58.1 & 23.0 & 1 & 1 & 4 & 1.5 & 1 & 2 & 3 & 2.0 & 7 & 1989 & 1.0 & 480 & & 1 \\
\hline 22 & 26 & 63.9 & 60.0 & 0.8 & 4 & 1 & 3 & 0.0 & & 2 & & 0.0 & & 1950 & 1.2 & 300 & & 1 \\
\hline 22 & 27 & 60.2 & 50.6 & 9.0 & 1 & 1 & 3 & 1.5 & 1 & 2 & 1 & 1.0 & 4 & 1930 & 1.0 & 440 & & 1 \\
\hline 22 & 28 & 0.0 & 28.8 & 2.0 & 13 & 1 & & 0.0 & & & & 0.0 & & & 0.0 & 500 & & 1 \\
\hline 22 & 29 & 55.8 & 40.4 & 2.0 & 1 & 1 & 3 & 1.0 & 1 & 3 & 1 & 1.0 & 3 & 1930 & 0.6 & 363 & & 1 \\
\hline 22 & 30 & 51.9 & 40.1 & 2.0 & 1 & 1 & 2 & 1.0 & 1 & 2 & 3 & 1.0 & 5 & 1910 & 1.3 & 80 & & 1 \\
\hline 22 & 31 & 74.4 & 58.6 & 9.0 & 1 & 1 & 3 & 1.0 & 1 & 2 & 2 & 1.0 & 6 & 1935 & 1.1 & 342 & & 1 \\
\hline 22 & 32 & 0.0 & 53.1 & 10.9 & 13 & 1 & & 0.0 & & & & 0.0 & & & 0.0 & 273 & & 1 \\
\hline 22 & 33 & 0.0 & 52.1 & 10.0 & 13 & 1 & & 0.0 & & & & 0.0 & & & 0.0 & 330 & & 1 \\
\hline 22 & 34 & 22.0 & 52.4 & 10.4 & 1 & 1 & & 0.0 & & & & 0.0 & & & 0.0 & 320 & & 1 \\
\hline 22 & 35 & 144.3 & 58.6 & 9.0 & 1 & 1 & 4 & 1.0 & 2 & 2 & 3 & 2.0 & 7 & 1986 & 1.1 & 568 & & 1 \\
\hline 22 & $35 A$ & 0.0 & 5.9 & 1.0 & 10 & 1 & & 0.0 & & & & 0.0 & & & 0.0 & & & 1 \\
\hline 22 & 36 & 0.0 & 56.0 & 13.0 & 71 & 1 & & 0.0 & & & & 0.0 & & & 0.0 & 1500 & & 1 \\
\hline 22 & 38 & 71.4 & 44.2 & 4.7 & 1 & 1 & 3 & 1.0 & 1 & 2 & 2 & 1.0 & 6 & 1978 & 1.1 & 260 & & 1 \\
\hline 22 & $38 \mathrm{~A}$ & 0.0 & 48.6 & 11.9 & 13 & 1 & & 0.0 & & & & 0.0 & & & 0.0 & 420 & & 1 \\
\hline 22 & 38B & 0.0 & 32.8 & 0.0 & 10 & 1 & & 0.0 & & & & 0.0 & & & 0.0 & & & 1 \\
\hline 22 & $38 \mathrm{C}$ & 0.0 & 16.6 & 0.0 & 10 & 1 & & 0.0 & & & & 0.0 & & & 0.0 & & & 1 \\
\hline 22 & 40 & 61.6 & 15.5 & 0.3 & 1 & 1 & 3 & 2.0 & 1 & 2 & 3 & 1.0 & 9 & 1930 & 0.8 & 106 & & 1 \\
\hline 22 & $40 A$ & 33.8 & 30.9 & 1.0 & 1 & 1 & 2 & 1.0 & 1 & 2 & 1 & 1.0 & 3 & 1932 & 0.4 & 203 & & 1 \\
\hline 22 & 41 & 67.4 & 33.9 & 1.9 & 1 & 1 & 3 & 1.5 & 1 & 2 & 3 & 1.0 & 6 & 1944 & 0.9 & 225 & & 1 \\
\hline 22 . & 42 & 57.1 & 24.8 & 0.5 & 1 & 1 & 3 & 1.0 & 1 & 2 & 3 & 1.0 & 6 & 1940 & 0.9 & 185 & & 1 \\
\hline 22 & 43 & 65.4 & 29.9 & 0.9 & 1 & 1 & 4 & 2.0 & 1 & 2 & 4 & 1.0 & 8 & 1880 & 0.8 & 1040 & 1 & 1 \\
\hline 22 & 44 & 0.0 & 19.5 & 0.5 & 13 & 1 & & 0.0 & & & & 0.0 & & & 0.0 & 265 & & 1 \\
\hline 22 & 45 & 58.8 & 24.1 & 0.3 & 1 & 1 & 4 & 1.5 & 1 & 2 & 3 & 1.0 & 6 & 1860 & 0.6 & 150 & & \\
\hline
\end{tabular}




\begin{tabular}{|c|c|c|c|c|c|c|c|c|c|c|c|c|c|c|c|c|c|c|}
\hline Map & Lot & $\begin{array}{l}\text { Bldg. } \\
\text { Value }\end{array}$ & $\begin{array}{l}\text { Land } \\
\text { Value }\end{array}$ & Acres & $\begin{array}{l}\text { Land } \\
\text { Uæ }\end{array}$ & Zoning & $\begin{array}{l}\text { Bldg. } \\
\text { Grade }\end{array}$ & $\begin{array}{l}\text { of } \\
\text { Stories }\end{array}$ & $\begin{array}{l}\text { Occu- } \\
\text { pancy }\end{array}$ & $\begin{array}{l}\text { Heat } \\
\text { Type }\end{array}$ & $\begin{array}{l}\text { "of } \\
\text { Beds }\end{array}$ & $\begin{array}{l}\text { of } \\
\text { Baths }\end{array}$ & $\begin{array}{l}\text { Total } \\
\text { Rooms }\end{array}$ & $\begin{array}{l}\text { Year } \\
\text { Built }\end{array}$ & $\begin{array}{l}\text { lat } \\
\text { Floor }\end{array}$ & Frontage & $\begin{array}{l}\text { Wet- } \\
\text { lands }\end{array}$ & $\begin{array}{l}\text { Water- } \\
\text { shed }\end{array}$ \\
\hline 22 & 46 & 71.6 & 30.3 & 0.6 & 1 & 1 & 4 & 1.5 & 1 & 2 & 5 & 2.0 & 8 & 1810 & 1.0 & 335 & & 1 \\
\hline 22 & 47 & 83.4 & 29.4 & 0.5 & 1 & 1 & 3 & 1.5 & 1 & 2 & 2 & 2.0 & 5 & 1964 & 1.1 & 110 & & 1 \\
\hline 22 & 48 & 87.4 & 25.6 & 0.6 & 1 & 1 & 3 & 2.0 & 1 & 2 & 3 & 2.0 & 7 & 1935 & 1.1 & 370 & & 1 \\
\hline 22 & 61 & 0.0 & 0.0 & 0.0 & 1 & 1 & 2 & 1.0 & 1 & 2 & 1 & 1.0 & 5 & 1970 & 0.4 & & & 1 \\
\hline 22 & $62 \mathrm{Cl}$ & 102.3 & 52.1 & 4.6 & 1 & 1 & 3 & 1.0 & 1 & 2 & 3 & 1.5 & 6 & 1980 & 2.1 & 403 & & 1 \\
\hline
\end{tabular}




\section{A T A $\mathbf{S}$ O U R C E D E T A I I}

Guidelines for classification

Typical Residential Structures - From the MMC Inc. Evaluators Manual

Luxurious - Excellent +20

A residence of this grade is an architect-designed residence which is unique. There will be no identical residence in the area. Excellent quality materials and workmanship will be found throughout. Typically, there will be special features such as unusual shape or design, an imposing entrance and elaborate windows or staircases. Aesthetically pleasing or special purpose features are often included in such properties even though they add considerably to the construction cost. A residence of this quality typically has about as many bathrooms as bedrooms.

Excellent - Excellent +10

This is a residence clearly superior to the average, mass produced home. There may be similar residences in the area, but few, if any, which are identical. Very good materials and workmanship are found throughout. Such a residence will have more than adequate structural, heating and plumbing features and typically more than adequate closet space. It may have some special purpose features but few, if any, which do not add utility equal to cost.

Average +20

This is an older grade residence (built before 1945) which may lack some of the features specified above, but it will have good plaster finish, extensive trim, (especially in the living room) and good workmanship throughout.

Average +10

This residence has features midway between average +20 and average grades.

\section{Average}

This residence is a standard contemporary house. Such residences built today are commonly mass-produced, usually with many parts identical to those of many others. They may be precut or prefabricated in whole or part. An average residence typically has standard doors, windows, plumbing and heating throughout with little ornamentation. Closet space is usually adequate in a new average grade residence but may be inadequate in older ones. 


\section{Below Average}

This residence is constructed of inexpensive, light-weight materials and finish. It typically has a minimum number of inexpensive windows, inexpensive heating and plumbing facilities which may be inadequate by contemporary standards. Such a residence typically has inadequate closet space and few built in cupboards or cabinets,

\section{Yinimum}

A minimum residence is typically constructed of minimum quality materials and lacks a full complement of features that are generally considered to be essential to provide year-round accommodations. It may be a structure designed for use as a seasonal home or a camp without heating facilities, with minimal foundation, wiring and plumbing facilities, few or no interior walls, single thickness exterior walls and single thickness floors instead of the standard double thickness. It may be a year-round home of similar construction with unfinished walls and ceilings and minimal structural components, plumbing, heating, and electrical wiring. 


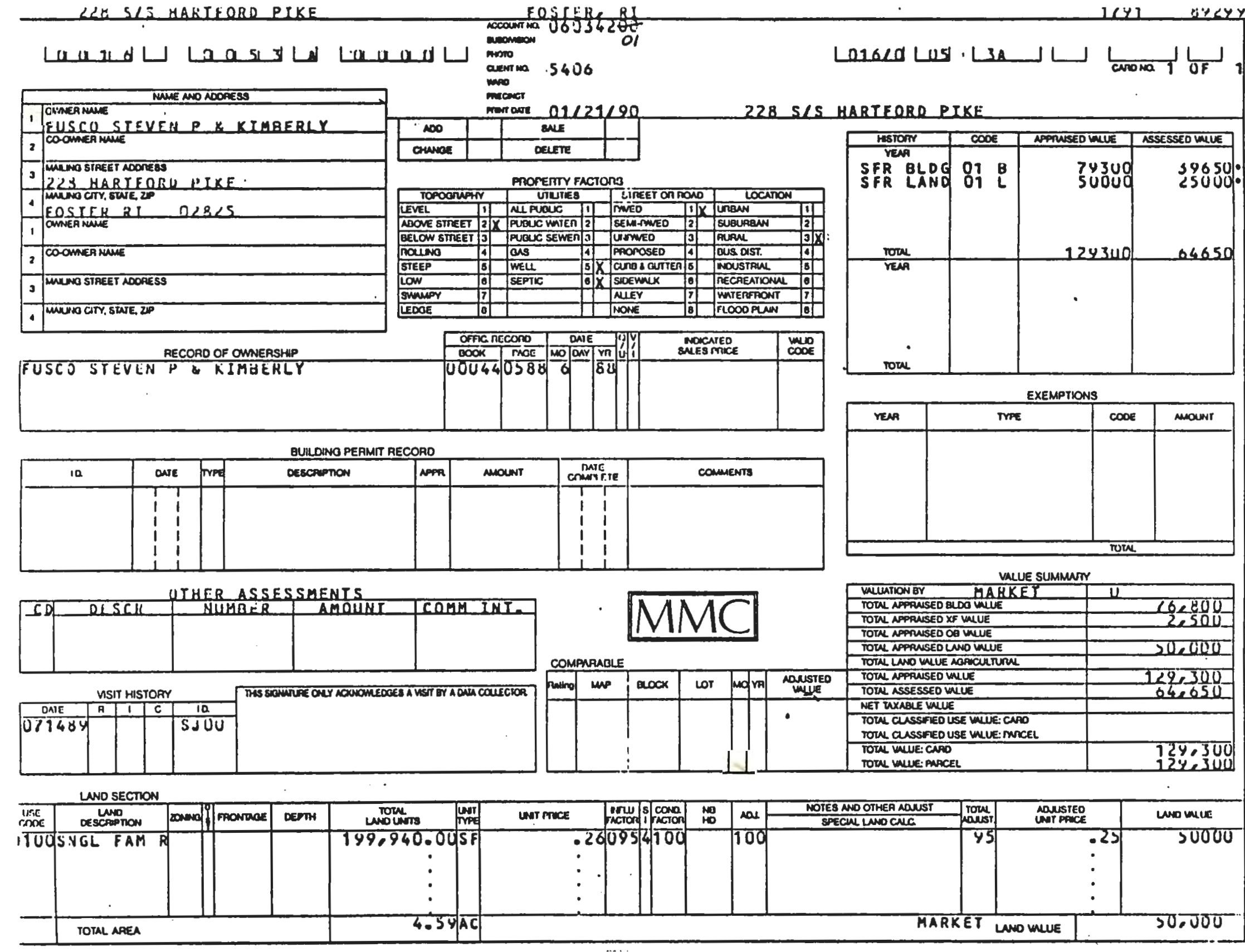




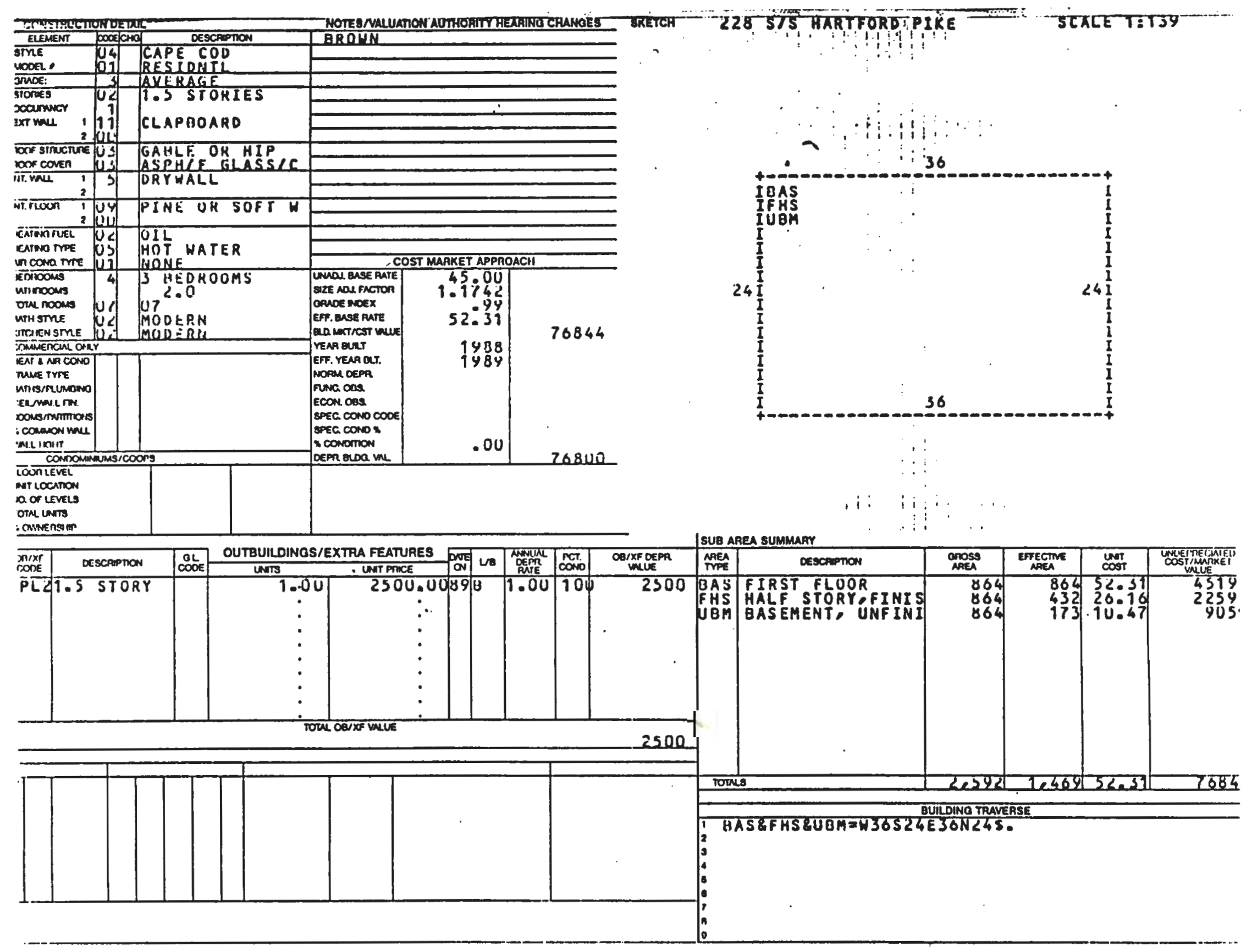


Alonso, William. 1983. A Theory of the Urban Land Market. Readings in Urban Analysis: Perspectives on Urban Form and Structure, ed. Robert $\omega$. Lake. New Brunswick, NJ: Center for Urban Policy Research: $1-10$.

American Planning Association. Osing Microcomputers in Orban Planning. Planning Advisory Service Report No. 372. Chicago: American Planning Association.

Bonczek, Robert H., Clyde W. Holsapple, and Andrew B. Whinston. 1984. Micro Data Base Management: Practical Techniques for Application Development. New York: Academic Press.

Brail, Richard K. 1987. Microcomputers in Urban Planning and Management. New Brunswick, New Jersey: Rutgers, The State University.

Burchell, Robert W., Listokin, David. and William R. Dolphin. 1985. The New Practitioner's Guide to Fiscal Impact. New Brunswick, New Jersey: Center for Urban Policy Research.

Chapin, Stuart F., Jr. and E.J. Kaiser. 1985. Urban Land Use Planning. Urbana: University of Illinois Press.

CPAD. 1989. The Hidden River. Kingston, RI: The University of Rhode Island Graduate Curriculum in Community Planning and Area Development.

Dame, Mark. 1989. Do Computers Make Better Deals? Orban Land 48:4 (April): 19-22.

Everett, Michael. 1982. Foster, Rhode Island: Comprehensive Plan. Providence, RI: Everett Associates.

Foster Planning Board. 1989. Recreation, Conservation, Open Space Plan: Foster, Rhode Island. Providence, RI: The state of Rhode Island, Division of Planning, Local Planning Assistance.

Griesemer, James R. 1983. Microcomputers in Local Government. Washington D.C.: International City Management Association.

Hansen, Walter G. 1959. How Accessibility Shapes Land Use Journal of the American Institute of Planners 25:2 (May): 73-6.

Holleran, Michael and Michael Everett. 1986. Foster Route 6 Commercial Strip: Planning Recommendations. Providence, RI: Everett Associates. 
Kindleberger, Charles. 1982. Reliance on Computers by Large American Planning Departments Past, Present, Future. St. Louis: St. Louis Community Development Agency.

Klosterman, Richard E. 1988. A Planners Review of PC Software and Technology. PAS Report No. 414/415. Chicago: American Planning Association.

Kops, Daniel W., Hall, Lawrence Jr., Goetze, Rolf and Geraldo Canto. 1986. Managing Municipal Information Needs Osing Microcomputers. PAS Report No. 393. Chicago: American Planning Association.

Kyd, Marilyn. 1989. Stalking the Wild Permit. Planning 55:9 (September): 24-7.

Langedorf, Richard. 1984. Computers and Decision Making Journal of the American Planning Association 52:4 (Autumn): 422-33.

Lieder, Constance. 1988. Planning for Housing. The Practice of Local Government Planning. 2d. Ed. Washington, DC: International City Management Association: 364-98.

Lima, Robert J. 1985. Planning Software Survey. PAS Report No. 388. Chicago: American Planning Association.

Marble, Duane, F. 1984. Geographic Information Systems Overview. PECORA 9 Proceedings Spatial Information Technologies for Remote Sensing Today and Tomorrow. October 2-4, Sioux Falls, South Dakota: 1824.

, Calkins, H.พ., and D.J. Peuquet. 1984. Basic Readings in Geographic Information Systems. Williamsville, N.Y.: SPAD Systems, LTD.

McHarg, Ian L. 1969. Design with Nature. Philadelphia, PA: Natural History Press.

Meyerson, Martin. 1956. Building the Middle-range Bridge for Comprehensive Planning. Journal of the American Institute of Planners. 22:2 (Spring): 58-64.

MMC Inc. 1989. Foster, RI; Fiscal Year 1989, Residential Manual. Chelmsford, MA.

Newton, P.W., and R. Sharpe, eds. 1988. Desktop Planning: Microcomputer Applications for Infrastructure and Services Planning and Management. North Melbourne, Victoria, Australia: Hargreen Publishers.

Ottensmann, John R. 1985. Using Personal Computers in Public Agencies. New York: John wiley. 
Rhode Island Department of Economic Development. 1987. Town of Foster Monograph. (July) Providence, RI: Research Division.

Rhode Island Department of Administration. 1989. Land Use 2010: State Land Use Policies and Plan. State Guide Plan Element 121, Report No. 64. (June). Providence, RI: Division of Planning.

Rhode Island Historical Preservation Commission. 1982. Foster, Rhode Island. Statewide Historical Preservation Report P-F-1. (June). Providence, RI: Rhode Island Historical Preservation Commission.

Robinson, Ira M. 1965. Beyond the Middle-range Planning Bridge. Journal of the American Institute of Planners. $31: 4$ (November): 304-312.

Rose, Albert E. and Jim Simpson. 1989. Capital Improvement Plan Tracked by Computer, Public Works 120:10 (September): 111-2, 181.

- 1989. "The Personal Computer Finds its Missing Link," Newsweek 3106 (June 5): 120-3.

Sawicki, David S. 1985. Microcomputer Applications in Planning. Journal of the Anerican Planning Association 51:2 (Spring): 209-15.

Scoggins, J., Tidrick, T.H., and Auerback J. 1986. Computer use in local government. The Municipal Year Book 1986. Washington, DC: International City Management Association: 33-45.

Searle, Cecilia,, Everett, Michael., and Joanna Doherty. 1976. A Rural Land Use Primer for Rhode Island. Kingston, RI: University of Rhode Island Agricultural Experiment Station and Cooperative Extension Service.

Standerfer, Norman R. and James Rider. 1983. The Politics of Automating a Planning Office, Planning 49:6 (June): 18-21.

United States Department of Agriculture Soil Conservation Service. 1981. Soil Survey of Rhode Island.

University of Rhode Island. 1988. 1988-89 Bulletin of The Oniversity of Rhode Island Graduate School. Kingston, RI.

Urban and Regional Information Systems Association. 1982. Computers, Environment and Urban Systems. New York: Pergamon Press.

Urban Center, Cleveland State University. 1987. Computer Applications in Economic Development: A Report to the Profession. PAS Report No. 403. Chicago: American Planning Association.

Winsor Associater. 1990. Housing Study for the City of Providence. Providence, RI. 